

\section{Food Heritage and Nationalism in Europe}

Food Heritage and Nationalism in Europe contends that food is a fundamental element of heritage, and a particularly important one in times of crisis. Arguing that food, taste, cuisine and gastronomy are crucial markers of identity that are inherently connected to constructions of place, tradition and the past, this book demonstrates how they play a role in intangible, as well as tangible, heritage.

Featuring contributions from experts working across Europe and beyond, and adopting a strong historical and transnational perspective, this book examines the various ways in which food can be understood and used as heritage. Including explorations of imperial spaces, migrations and diasporas, the role of commercialization processes, and institutional practices within political and cultural domains, this volume considers all aspects of this complex issue. Arguing that the various European cuisines are the result of exchanges, hybridities and complex historical processes, Porciani and the chapter authors offer up a new way of deconstructing banal nationalism and of moving away from the idea of static identities.

Suggesting a new and different approach to the idea of so-called national cuisines, Food Heritage and Nationalism in Europe will be a compelling read for academic audiences in museum and heritage studies, cultural and food studies, anthropology and history.

Ilaria Porciani teaches modern and contemporary history at the University of Bologna. She has published widely on the history of education, culture, the university, historiography and nation-building, often incorporating a gender approach. Her present research interests focus on public history, history museums and food history. 
Critical Heritages of Europe

Series editors: Christopher Whitehead and Susannah Eckersley, both at the University of Newcastle, UK

The Critical Heritages of Europe series seeks to explore the cultural and social politics of the European past in the present. Bridging theoretical and empirical research, the series accommodates broad understandings of Europe - a shifting and historically mutable entity, made both of internal tensions and exogenous encounters, re-imaginings and influences. 'Heritage' too is taken as an expansive paradigm, made in myriad practices where the past is valorised for the present, from folk traditions to museums and memorials, the management of historic sites and traditions, and everyday matters such as education, political discourse, home life, food consumption and people's relations with place. Consequently, the series spans a broad array of foci, disciplinary approaches and ways of investigating and questioning the diverse meanings of European heritages today.

\title{
Classical Heritage and European Identities
}

The Imagined Geographies of Danish Classicism

Lærke Maria Andersen Funder, Troels Myrup Kristensen and Vinnie Nørskov

\section{Heritage and Festivals in Europe}

Performing Identities

Edited by Ullrich Kockel, Cristina Clopot, Baiba Tjarve and Máiréad Nic Craith

\section{Dimensions of Heritage and Memory}

Multiple Europes and the Politics of Crisis

Edited by Christopher Whitehead, Susannah Eckersley, Gönül Bozoğlu and Mads Daugbjerg

\section{European Heritage, Dialogue and Digital Practices \\ Edited by Areti Galani, Rhiannon Mason and Gabi Arrigoni}

\section{European Memory in Populism}

Representations of Self and Other

Edited by Chiara De Cesari and Ayhan Kaya

\author{
Populism and Heritage in Europe \\ Lost in Diversity and Unity \\ Ayhan Kaya
}

\section{Food Heritage and Nationalism in Europe \\ Edited by llaria Porciani}

https://www.routledge.com/Critical-Heritages-of-Europe/book-series/COHERE 


\section{Food Heritage and \\ Nationalism in Europe}

\section{Edited by llaria Porciani}


First published 2019

by Routledge

2 Park Square, Milton Park, Abingdon, Oxon OXI4 4RN

and by Routledge

52 Vanderbilt Avenue, New York, NY 10017

Routledge is an imprint of the Taylor \& Francis Group, an informa business

(C) 2019 selection and editorial matter, llaria Porciani; individual chapters, the contributors

The right of llaria Porciani to be identified as the author of the editorial material, and of the authors for their individual chapters, has been asserted in accordance with sections 77 and 78 of the Copyright, Designs and Patents Act 1988.

With the exception of Chapters I, 2, 4,6 and I2, no part of this book may be reprinted or reproduced or utilised in any form or by any electronic, mechanical, or other means, now known or hereafter invented, including photocopying and recording, or in any information storage or retrieval system, without permission in writing from the publishers.

Chapters I, 2, 4, 6 and I 2 of this book are available for free in PDF format as Open Access from the individual product page at www.routledge.com. They have been made available under a Creative Commons Attribution-Non Commercial-No Derivatives 4.0 license.

Trademark notice: Product or corporate names may be trademarks or registered trademarks, and are used only for identification and explanation without intent to infringe.

British Library Cataloguing-in-Publication Data

A catalogue record for this book is available from the British Library

Library of Congress Cataloging-in-Publication Data

Names: Porciani, llaria, editor.

Title: Food heritage and nationalism in Europe /

[edited by] llaria Porciani.

Description:Abingdon, Oxon ; New York, NY : Routledge, [2020] |

Series: Critical heritages of Europe |

Includes bibliographical references and index.

Identifiers: LCCN 2019029096 (print) | LCCN 2019029097 (ebook) |

ISBN 9780367234I57 (hardback) | ISBN 978042927975 I (ebook)

Subjects: LCSH: Food habits-Political aspects-Europe.|

Food habits-Social aspects-Europe. | Nationalism-Europe. |

Cooking, European. | Europe-Relations.

Classification: LCC GT2853.E8 F69 2020 (print) |

LCC GT2853.E8 (ebook) | DDC 394.I/2094-dc23

LC record available at https://lccn.loc.gov/2019029096

LC ebook record available at https://Iccn.loc.gov/2019029097

ISBN: 978-0-367-234I5-7 (hbk)

ISBN: 978-0-429-27975-I (ebk)

Typeset in Bembo

by Newgen Publishing UK 


\section{Contents}

List of figures

vii

Notes on contributors

ix

Acknowledgements

\section{Introduction}

1 Food heritage and nationalism in Europe

ILARIA PORCIANI

\section{PART I}

Heritagization and political uses of food

2 Heritage and food history: a critical assessment

LAURA DI FIORE

3 Tradition, heritage and intellectual property in the global food market

FABIO PARASECOLI

4 Food and locality: heritagization and commercial use of the past PAOLO CAPUZZO

5 In the kitchens of '68: the impact of student protest and counterculture on attitudes towards food MARICA TOLOMELLI

6 A place at the table? Food in museums as an

"Ersatz politics" of difficulty 


\section{PART II}

Contact zones and exchanges

7 A taste for diversity MASSIMO MONTANARI

8 Franz Joseph's Tafelspitz: Austro-Hungarian cooking as an imperial project

CATHERINE HOREL

9 Images, perceptions and authenticity in Ottoman-Turkish cuisine ÖZGE SAMANCI

10 Station buffets and universal exhibitions: places of mobility for crossing food cultures

JEAN-PIERRE WILLIOT

11 Canteens, cafés and cabarets: the food culture of the Russian diaspora in Shanghai, 1920-1950

KATYA KNYAZEVA

\section{Conclusion}

12 Careful with heritage 


\section{Figures}

2.1 Food in UNESCO Intangible Cultural Heritage 40

3.1 Geographical Indications in the World 57

3.2 Slow Food - Ark of Taste 60

4.1 Pellegrino Artusi, La scienza in cucina e l'arte di mangiar bene. Recipes. Place of origin $\quad 68$

5.1 Slow Food presidia and earth markets 92

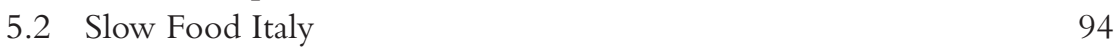

6.1 CULINARIUM exhibition as part of Open Air Museum Domain Dahlem Berlin, display: "So isst Berlin" 102

6.2 CULINARIUM exhibition as part of Open Air Museum Domain Dahlem Berlin: teacups and table setting display 103

6.3 Döner kebab display, Museum Europäischer Kulturen Staatliche Museen zu Berlin 105

6.4 CULINARIUM exhibition as part of Open Air Museum Domain Dahlem Berlin: display board "Eating in East Germany"

6.5 CULINARIUM exhibition as part of Open Air Museum Domain Dahlem Berlin: display board "Eating in West Germany"

6.6 a-c Gdańsk Museum of the Second World War, children's $\begin{array}{ll}\text { exhibition } & 114\end{array}$

6.7 Gdańsk Museum of the Second World War, highly designed area with food-related content

6.8 a. Auschwitz Museum, large display of cooking pots.

b. Auschwitz Museum, small display of food utensils

8.1 Austro-Hungarian Empire 141

9.1 Ottoman Culinary Empire 163

10.1 Chemins de fer de l'Etat, La gare est aujourd'hui ce qu'é tait
autrefois la place de la ville, Paris, Draeger imp. [1930] 
10.2 Chemins de fer du Nord, Guide du voyage, Paris, Bonaventure et Ducessois imp. [1850]

10.3 Tableau auxiliaire Delmas pour l'enseignement pratique des langues vivantes par l'image. Série III: N¹2- La Gare, Delmas (G.), Bordeaux (circa 1900) 


\section{Notes on contributors}

Paolo Capuzzo teaches world history and Italian contemporary history at the University of Bologna. He is the chair of the Department of History and Culture. His research interests focus on two main fields: the history of material culture, food and consumption, and the global history of communism and Gramscian studies.

Laura Di Fiore teaches the history of political institutions at the University of Naples Federico II. She studies institutions in a social and global perspective. She has published books and articles on different topics, including the construction of European borders between the 18th and 19th centuries, identification practices and political police and 20th-century British imperial history.

Susannah Eckersley is Senior Lecturer in museum, gallery and heritage studies at Newcastle University, UK, with expertise in museums and difficult heritage (in particular relating to German history). She was the deputy coordinator of CoHERE: Critical Heritages - performing and representing identities in Europe. She is the project leader for en/counter/points - a new collaborative research project on culture and integration in Europe from 2019 to 2022 .

Catherine Horel is the research director at CNRS, SIRICE, Paris I University. She is a specialist in the history of Central Europe, the Habsburg Empire and Hungary. Her many publications deal with sociopolitical structures and with urban, military and Jewish history, as well as with lieux de mémoire. She is currently serving as the general secretary of the International Committee for Historical Sciences (CISH).

Katya Knyazeva, from Novosibirsk, Russia, is a journalist and a researcher with a focus on urban history. She is the author of the two-volume historical and photographic atlas Shanghai Old Town (2nd edition 2018). Since 2016 she has been pursuing her second master's degree in global cultures at the University of Bologna. 
Massimo Montanari teaches medieval history at Bologna University. He has been a pioneer in food history, including wide-ranging areas such as economics, social issues, politics, culture and religion. From 1979 onwards, he has published a number of books about these topics, translated into several languages. He is the founder and director of the "food history and culture" master's degree instituted in 2002 at Bologna University.

Fabio Parasecoli is a professor of food studies at New York University. His research explores the intersections between food, popular culture and politics, particularly in food design. Recent books include Al Dente: A History of Food in Italy (2014), Feasting Our Eyes: Food, Film, and Cultural Citizenship in the US (2016, authored with Laura Lindenfeld) and Knowing Where It Comes From: Labeling Traditional Foods to Compete in a Global Market (2017).

Ilaria Porciani teaches modern and contemporary history at the University of Bologna. She has published widely on the history of education, culture, the university, historiography and nation-building, often incorporating a gender approach. Her present research interests focus on public history, history museums and food history.

Özge Samanc1 is an associate professor of Ottoman food history and head of the Gastronomy and Culinary Arts Department at Özyeğin University in Istanbul. Her studies and research focus on the modernization process of Ottoman-Turkish culinary culture and Ottoman food historiography. She is the author of Flavours of Istanbul (2007), Turkish Cuisine (2008) and La Cuisine d'Istanbul au 19e siècle (2015).

Marica Tolomelli teaches contemporary history at the University of Bologna. She gained her $\mathrm{PhD}$ at the University of Bielefeld. Her research interests are 20th-century European history and social, labour and gender conflicts in the 1960s and 1970s from a comparative and transnational approach. She is the editor of the online journal Storicamente (www.storicamente.org).

Jean-Pierre Williot is a professor of economic history at Sorbonne University, Paris. His fields of research include the history of innovation with topics on the history of food, energy and railways. He is the author or co-author of 20 books, and he is the co-director of the collection European Food Issues. 


\section{Acknowledgements}

This book is a result of the European Union-funded Horizon 2020 research project CoHERE (Critical Heritages: performing and representing identities in Europe). CoHERE received funding from the European Union's Horizon 2020 research and innovation programme under grant agreement no. 693289.

I have been working on nationalism for a very long time, and on heritage for the past few years, but until 2010, when together with Massimo Montanari I started a seminar on political cuisine at the University of Bologna, I had never translated my curiosity about food and cooking into a topic to work on. Thanks to the EU Horizon 2020 project CoHERE, I have been able to focus on food, nationalism and heritage together. Without the support of that project this book would have never been written or published. Therefore, I wish to express my gratitude for being given this great opportunity to engage in a broad European project, one which has brought together many scholars from many different countries and backgrounds and widened our knowledge and perspectives.

Firstly, I should like to thank Christopher Whitehead and Susannah Eckersley, coordinator and deputy coordinator of CoHERE, who accepted the challenge as well as the burden of coordinating this intellectually rich, multi-focused, interdisciplinary and diverse research project. I also wish to thank my colleagues in this adventure, especially those at the universities of Bologna and Athens who were members of the working package focusing on food as heritage.

I am deeply indebted to Massimo Montanari, who brought his extensive knowledge of food history to the project, and to Paolo Capuzzo, who has been interested in the history of consumption for many years and who gave excellent suggestions for the preparatory conferences. Laura Di Fiore compiled the impressive bibliography: the first fruits of our working package and a resource of substantial help in putting together this book. Laura was also an outstanding organizer of two conferences held at the Department of History and Culture (Bologna University): "Food as Heritage" (2017) and "Taste of Diversity" (2018). These gatherings provided a great opportunity to meet scholars from various countries and to involve them in different ways in the project. 
Not all the participants at these conferences have been published here, but all of them made our discussions richer. I would like to express my special gratitude to Peter Scholliers, who gave invaluable suggestions, and to Davide Domenici, who provided an external perspective on food as heritage starting from the "margins", that is from the Mexican case. Every other meeting of the CoHERE project was also rich in suggestions, from the review meeting in Brussels - and here I wish to thank Peter Aronsson for his comments - to the closing general CoHERE conference "Who Is Europe?" held in November 2018 at Polin, the Museum of Polish Jews in Warsaw. Ultimately, this is what EU research is about: constructing truly European international communities and sharing ways of thinking, exchanging opinions, approaches and perspectives, and providing open-access results.

I wish to thank Nieves López Izquierdo, who prepared maps on food as heritage, some of which are published here.

My special thanks go to Giacomo Bonan for his careful updating of the bibliography and for assisting me in the final preparation of this book with constructive criticism, creativity, promptness and good humour. Ralph Nisbet translated and carefully edited the English of most of the chapters. Michael Godfrey translated Jean-Pierre Williot's chapter and edited Özge Samanc1's.

I had several opportunities to present this project to other scholars from whom I received stimulating feedback: Mahnaz Yousefzadeh and Mark Swislocki at New York University-Abu Dhabi; Paula P. Johnson and Ashley Rose Young, curators in the food department at the Smithsonian Museum of American History, who gave me a better understanding of the use of food in museums as well as of the culinary transfers of cuisines between Europe and the United States; and the director and staff at the Casa Artusi in Forlimpopoli. Many excellent and precious suggestions came also from Chris Whitehead and the anonymous reviewers, as well as from Heidi Lowther at Routledge. I should like to express my gratitude to them.

I also wish to thank my students at the University of Bologna: I have always found it an enriching experience to discuss the topic of this book with them.

Last - but by no means least - I wish to thank the library of the Department of History and Culture of the University of Bologna and the library of the European University Institute in San Domenico di Fiesole. The countless books and digital resources that they have provided, as well as the great competence and helpfulness of their librarians, constituted the conditio sine qua non of my work for this book.

In closing these acknowledgements, I feel I must think back to all those who gave me a true sense of different cooking traditions and local or national tastes. The list starts with my two grandmothers: Augusta, a great cook who never wrote down a recipe on her own, and Clelia, the daughter of a restaurant owner, who combined a Tuscan taste with her deep knowledge of international cuisine. As a teenager living with a French family in Tain l'Hermitage I learned the secrets of potages and pot au feu long before reading Jean-Louis Flandrin's 
book La blanquette de veau. Histoire d'un plat bourgeois (2000), and I started getting a sense of the important role that cuisine has long had for the French. In my student years my flatmates in various Italian cities as well as in my German Wohngemeinschaften helped me to learn how much cooking together leads to an understanding of different cultures. My son Niccolò had a similar experience during his Erasmus year. My own work on this book is therefore dedicated to him and to his wife, Virginia, both great cooks with a curiosity about old recipes and the skill to transform them into wonderful home cooking.

Ilaria Porciani

Bologna, January 2019 
$\because$ Taylor \& Francis Taylor \& Francis Group

http://taylorandfrancis.com 
Introduction 
$\because$ Taylor \& Francis Taylor \& Francis Group

http://taylorandfrancis.com 


\title{
Food heritage and nationalism in Europe
}

\author{
Ilaria Porciani
}

\section{Food: heritage for uncertain times}

More than ever, food occupies a central place in our thoughts and our imagination. The less we cook or eat in a decent way, the more we are concerned with the meaning and strategies of cooking, the authenticity of recipes and their normative grammar. Food, the most accessible threshold of culture (La Cecla 1997), is ubiquitous in television series and programmes, films (Saillard 2010), magazines, newspaper articles and novels (Biasin 1991; Ott 2011), as well as in recent and very popular detective stories. Commissario Montalbano, created by Andrea Camilleri, makes a point of praising the true Sicilian cooking of his housekeeper while despising the cuisine from distant, albeit Mediterranean, Liguria as prepared by his fiancée.The hero of Petros Markaris's detective novels, Inspector Costas Charitos, a Rum - that is, a Greek born in Istanbul - explores contact zones and frictions between the often overlapping cuisines of the two communities. The detective created by Manuel Vásquez Montálban constantly describes local and national dishes from his country in vivid detail, and mirrors the tension between local, Catalan and national cuisine. Why should this be so if these attitudes did not speak immediately to everyone?

In every culture, "foodways constitute an organized system, a language that through its structure and components - conveys meaning and contributes to the organization of the natural and social world" (Counihan 1999, 19). Worldwide, as well as across social classes and different milieus, food conveys feelings of community and inclusion. Food reminds us of the protective intimacy of the private home and the national home at one and the same time. Besides being a powerful means of integration within a group for some, it enables recognition within a taxonomic classification (Fischler 1988). Yet it can also effectively voice "othering" and disgust for others. Thus the emotional connection between food and the feeling of national belonging is also used and misused by politicians in various countries to mobilize the masses.

In times of presentism (Hartog 2015), heritage-making is a response to anxieties about malbouffe - fast food, bad food and bad eating habits (Binet 2016) - "MacDonaldization", the consequences of extreme industrial food 
manufacturing and the fear of globalization and mass immigration. The need to create food heritage is partly the result of a longing for grandmothers' "authentic" cuisine, with its supposedly deep roots in our traditions, which are meant to be rediscovered and protected. Edible chronotopes (KirshenblattGimblett 2004, xiii) contain and embody the memory of people and places through time and space. When food is designated as heritage it "takes on even greater emotional weight" (Brulotte and Di Giovine 2014, 2).

These fantasies are often entangled with the nostalgia (Boym 2001; Duruz 1999; Renko and Bucar 2014; but also Holak 2014; Holtzman 2006, 367-8; Mannur 2007) characteristic of the most extreme cases of contemporary nationalism. Often it is nostalgia for a rural "countryside-nation" such as is proposed in open-air museums (Skansen in Norway or Beamish in the United Kingdom being two good examples) or in the English television heritage series devoted to Avis Crocomb, which attracted not fewer than 12 million viewers online alone. The chief cook of Lord and Lady Braybrooke at Audley End House in the Victorian age is shown picking fresh fruit from a very English orchard, or preparing English breakfast in the authentic castle's historical kitchen. A wave of nostalgia for the rural past was evident in Japan as well (Cwierta 2006).

While our society becomes liquid (Baumann 2000) and our world is characterized by a "global ethnoscape" (Appadurai 1996) largely deterritorialized and marked by a new irrelevance of space, we are drawn to imagine food in terms of authenticity, tradition and terroir - a French word which designates a rather small terrain "whose soil and microclimate impart distinctive qualities to food products" (Barham 2003, 131; Demossier 2016; Saillard 2010). Because we are losing contact with things and practices which used to be alive and familiar, we turn them into heritage (Nora 1989). This trend is by no means confined to food: heritagization is a much wider phenomenon in almost all countries Europe being probably at the forefront.

Closely connected to this context is the "heritage vegetable discourse" centred on guardianship. Its linear narrative presents the past "not only as better, freer and more diverse, but also unchanging", and emphasizes a continuity with past generations, which may be "a matter of centuries as in the documents issued by the British National Trust, millennia or even prehistory as in the Science and Advice for Scottish Agricultural Website" (Wincott 2015, 577-8). Abigail Wincott classifies the British organizations involved under the following broad categories: "heritage conservation bodies (such as the National Trust and the Heritage Seed Library), activist groups (for example Reclaim the Fields), lifestyle journalists and experts, seed catalogues and garden centres, those selling heritage vegetables and fruit as luxury or premium food (these include restaurants and supermarkets, selling heritage vegetables in their luxury food ranges) and academics studying traditional crops". The mapping of the field of actors - she points out - "is successful in giving an indication of how broad the range of activities is, stretching from anticapitalist agitation to fine-dining and it throws up some interesting questions about the role of mainstreaming and 
different models of funding" (Wincott 2015, 574-5). Although related only to the United Kingdom, this picture mirrors the variety of subjects and agencies involved in the process of heritagization.

In being turned into heritage, food becomes part of a transaction. Like every other kind of heritage understood as such, it is the object of a pact (or unspoken contract) between those who confer heritage status on it and the people. In the 19th and 20th centuries the blueprint of this quite informal pact "profoundly linked to nation-building" (Adell, Bendix, Bortolotto and Tauschek 2016, 7) was written by national intellectuals and folklorists engaged in researching the national traditions of the people, and producing the nationalpopular master narrative in order to promote what they called the national "awakening". Ministries and public bodies of newer or older nation states and also supranational institutions contributed further, and so did many cooks and middle-class housewives, aristocrats and gourmets who volunteered to participate in the informal task of creating a culinary identity for the nation.

In recent times, new tools have been created to "enhance and protect the legal, commercial and cultural values of foods and customs whose characteristics and reputation can be variously attributed to their origin" (Parasecoli 2017,2). On one hand are place-based labels such as Protected Designation of Origin (PDO) as well as the broader category of Geographical Indication (GI); on the other hand is UNESCO's list of Intangible Cultural Heritage (ICH). UNESCO mentioned intangible cultural heritage in its 1989 Recommendation for the Safeguarding of Traditional Culture Folklore. However, it was not until 2003 that UNESCO's Convention for the Safeguarding of the Intangible Cultural Heritage was passed, and only from 2010 was food included (Clough 2015; Di Fiore 2018a).

More than ever this process of heritagization of food (as of other "things" and tangible or intangible practices) is characterized by the logic of cultural engineering based on nation states (Adell et al. 2016; Hannerz 2006, 79; Kuutma 2012, 30) and can lead to ambiguities and shortcomings (Hertz 2017). It is governed by a nomos and enters a complex system of negotiations. While free intellectuals are still vocal about the topic, it is public bodies that are appointed as culinary or food quality authorities. In this case the pact becomes more complicated and its effect more coercive. The official grammar triumphs over vernacular languages and dialects, and hierarchies are constructed. Some foods are included; others are necessarily excluded. French scholars have reflected on surclassement patrimonial - that is, the effect of skating over a great variety of possible heritage while projecting a highly selective light of heritage only on a few things or practices. The picture becomes complicated and conflictual, because authorized heritage discourse - be it local, national, multinational or supranational - privileges some actors while disengaging others from the active use of heritage (Smith 2006).

Food heritage reconfigures relations of power and meaning as well as practices, and has an immediate impact on production, consumers and commodities: in 
short, on the market. Put succinctly, heritage becomes one arena of cultural propertization (Bendix, Eggert and Peselmann 2012). Moreover, it brings about a new way of constructing a narrative about what has been recognized as heritage (Fox 2007, 554). This happens in the case of geographical quality indications as well as in UNESCO's list of intangible heritage. In both cases, competitive confrontation among states or regions - originally probably unintended - is in reality a major result of these procedures. Moreover, food is part of the important recent process of commercializing memory cultures (Narvselius 2015, 417): the market amplifies constructed memories and traditions and makes intensive use of often simplified and invented culinary traditions.

Discussing food heritage implies navigating between operational definitions (principally UNESCO's) and the scholarly ones, including the definition suggested by Christopher Whitehead, Gönül Bozoğlu and Mads Daugbjerg (2019): heritage is "a representational, discursive and performative practice involving conscious attempts to symbolically valorize aspects of the past in the present". This prompts useful considerations. First of all, it brings to light how difficult it is to define heritage, and how senses of heritage have changed over time. Secondly, it sheds light on the implicit or explicit political intentions behind inventories and norms of protection, but also the accurate definition of the specific qualities needed in order to consider a practice as part of patrimoine. Thirdly, it helps to better understanding what David Lowenthal already pointed out many years ago: heritage "distinguishes us from others. It gets passed only to descendants, to our own flesh and blood; newcomers, outsiders, foreigners all erode and debase it" (Lowenthal 1994, 47). Working on the complexity of food as heritage can help to deconstruct such assumptions showing entanglements and overlaps, as well as highlighting shared practices among many people in Europe and sometimes across the Mediterranean.

The long-term perspective of most of the chapters of this book will help to focus on how these perspectives have changed from the long 19th century - the century of nationalisms, when heritage was inextricably connected to nations to recent steps aiming to establish certain foods as world intangible heritage. Moreover, the double nature of food as a material "thing" made of ingredients and as a long-lasting but also perpetually evolving practice complicates the picture. As Laura Di Fiore explains in Chapter 2 of this volume, the UNESCO 1972 definition of heritage at first did not accommodate food as heritage: food came later, and not without problems.

In order to shed light on those issues, the first section of this book deals with the political issue of food in processes of heritagization (Di Fiore, Chapter 2) and labelling (Parasecoli, Chapter 3), within market strategies (Capuzzo, Chapter 4), in politically oriented movements (Tolomelli, Chapter 5) and in museums (Eckersley, Chapter 6). Part II of this book tries to explain why it is difficult to consider food as "original national heritage", because of the many exchanges and grafting processes over a long period, though more specifically since the Middle Ages (Montanari, Chapter 7) and in the subsequent 
empires (Horel, Chapter 8; Samanc1, Chapter 9). It also focuses on the 19th and early 20 th centuries by drawing attention to restaurants in different global contexts: the Universal Exhibitions (Williot, Chapter 10) and global trade (Knyazeva, Chapter 11).

\section{Food heritage and nationalism: state of the art}

In the 1980s nationalism and food studies started to be identified as precise scholarly fields. However, due to the existing disciplinary borders they proceeded in parallel. In the 1980s heritage studies too was established as a specific discipline, but it took some time before it turned towards the topic of food (Poulot 2015). Until a few years ago, cross-fertilization was limited. One important exception was Nora's seminal Lieux de mémoire, where a chapter on gastronomy and one on wine (Durand 1992; Ory 1992) figured prominently among the traditions of the nation. For France, it would probably be impossible to omit either of them, both for the role of gastronomy in nation-building and for the early interest in the topic of food shown by French historiography (Flandrin 1992, 1999, 2000; Pilcher 2012, 44; Rowley 1997, 2006; Watts 2012).

Hobsbawm focused on the invention of tradition and on nationalism (Hobsbawm 1983, 1990), but failed to mention food, and so did Ernst Gellner (1983) and many others, including those authors who focused on nationhood from below, or on the gendered nature of nation-building processes (Blom, Hagemann and Hall 2000). Food is quoted only twice (and not in connection with its symbolic power) in Billig's Banal Nationalism (Billig 1995).

While in 2004 Ben Rogers still lamented that historians and sociologists had not taken much interest in nationalism of the culinary kind (Rogers 2004), the picture has changed in the past few years. Building on the earlier works of Claude Lévi-Strauss (1958), Mary Douglas (1966) and Roland Barthes (1961), recent scholars have highlighted that food-related practices can be read as signifying systems whose meanings are determined by the cultural context. It has become clear that "in every culture, food-ways constitute an organized system, a language that - through its structure and components - conveys meaning and contributes to the organization of the natural and social world" (Counihan 1999, 19; Counihan and Kaplan 1998). Historians (Scholliers 2001) and anthropologists have discussed the symbolic significance of food in the construction of national self-identity (Ohnuki-Tierney 1993).

In recent years, however, as part of a new attention to banal nationalism, scholars have started to investigate the role of food in the perception and construction of the nation. With the help of historians, anthropologists, sociologists and heritage scholars, research on food heritage and nationalism has grown immensely (Di Fiore 2018b). Bessière (2001) describes food heritage as a set of material and immaterial features in a community's food culture that have become recognized as a common good: a broad set, not excluding innovation (Bessière 2010; Bessière and Tibère 2010) and including foods and recipes, 
kitchen utensils or ways of eating together and even of setting the table. This is not without its significance: many national museums have found room for table-laying, a crucial point of middle- and lower-class domestic life and upperclass ostentation.

Some scholars (Ramli, Zahari, Ishahk and Sharif 2013) have concentrated on how food heritagization has tied up with the tradition of foods prepared and consumed over an unbroken sequence of generations. As one reads them, though, the doubt immediately arises that in many cases these traditions may not have been so continuous, and that some invention and reinvention may have taken place (Hobsbawm and Ranger 1983; Holtzman 2006). Others have tried to divide the gastronomic heritage into two categories: foods that form part of everyday life and foodstuffs that are disappearing or have already disappeared. The memory of a food may linger even after it has vanished, and may go on fuelling nostalgia, as some folklorists intuited many years back (Evans 1942, 73).

Parkhurst Ferguson (2010) reflected on culinary nationalism and De Soucey even coined the term gastronationalism (de Soucey 2010). Scholars have started investigating culinary politics and its role in the consolidation and transformation of nation states, as in Japan (Ichijo and Ranta 2016); they have highlighted how important those policies were in consolidating community ties and affirming strong political identities (Gvion 2011). Aykan speaks of a new "food heritage fever" (Aykan 2016, 799) while Demossier has investigated the role of terroir (Delfosse 1997, 2011; Demossier 2016), which had become a clear issue even in French state banquets during Chirac's presidency (Roux 2017): in fact, nowhere is the symbolic meaning of food more in evidence than at public events. Julia Csergo wrote of her own experience as a scholar in charge of the UNESCO candidature of the gastronomic meal of the French (Csergo 2016; Tornatore 2012). The debate on the politics of protected and controlled GIs and the complexities of labelling lead on to global issues, as Parasecoli also shows in this book. And it is on a global scale that the issue of immaterial heritage has arisen, as proposed by UNESCO ever since developing countries and the Global South and North began pressing for broader, more inclusive definitions of heritage, taking account of what they perceive as heritage, as against Eurocentric standards. Laura Di Fiore explains this well in her chapter for this book.

Old as well as recent hostilities between countries have often fuelled food wars, and clearly impact UNESCO applications. As Ubertazzi $(2015,114)$ has pointed out, "in certain cases, the proposal of these multinational nominations proves impossible for example, when the same states concerned are at war with each other, or are experiencing bad relations for whatever reason." This is the case with kimchi (Han 2011), the candidature for which described it as an essential part of the Korean way of life. ${ }^{1}$ Historians have also followed the disputes between Indonesians and Malese (Chong 2012).

Scholars, increasingly interested in conflicts, have followed and interpreted recent food wars, starting from the one between Greeks and Romanians about sarma or feta cheese (Mihăilescu 2012) and between Greek Cypriots, Turks and 
Cypriots, based on the contested UNESCO nomination of Lokoumi (Welz 2013). They have analysed the war over the property of falafel contested between Palestine and Israel (Raviv 2003), or over hummus among Israelis, Palestinians and Lebanese (Ariel 2012), all increasingly relevant to UNESCO nominations to $\mathrm{ICH}$.

In 2017 a new food heritage war between Israeli and Palestinians crystallized around zatar: Palestinians wish to repeat ancient rituals and get together to gather it, while Israeli authorities are trying to protect this herb, probably mentioned in the Bible and in danger of extinction. Haaretz pointed out that this war has been going on since 1977, when environmentalists succeeded in transforming the list of 257 protected species into law. The Palestinian Heirloom Society was also set up to protect something belonging intimately to Palestinian identity. Once more, the struggle is both an identity and a commercial battle, while top chefs use the herb to create internationally successful dishes (Frattini 2017).

The case of the protest against the label "Palestinian salad" on a dish with a couscous base, offered by Virgin Atlantic Airlines (which was apparently forced to change the name to "couscous salad") is a good instance of how the reference to a regional or typical dish in an attempt to be commercially attractive can turn into a disaster. But even more interesting is the airline's reply: "Maftoul is Palestinian, just like pasties are Cornish and pâté de foi gras is French." But are we sure that the French can claim foie gras as a national dish, when precisely this dish has a distinct pre-national origin in Jewish cuisine? Food historians know very well that duck was notoriously the Jews' pork, and back in the 16th century Bartolomeo Scappi or Marx Rumpolt recommended preparing foie gras from the liver of ducks raised by Jews in various areas, especially Bohemia (Toaff 2004,275-81). This is a clear example of how a dish may become "nationalized" when its long diaspora history, characterized by mediation and hybridism, is neglected.

\section{Food and national branding: gastrodiplomacy}

"[Catalonia] is not an invention: there is a territory, a community, a language, a culture and, in my case, a cuisine. Thus, my friends, this is a nation" (quoted in Pujol 2009, 438). In 2006 chef Carme Ruscalleda openly supported Catalan nationalism through gastronomy with this strong statement. The new use of food in national narratives with different aims - as diverse as encouragement of devolution, or promotion of the national brand - has become so important that the old term of culinary diplomacy, still used by some scholars (ChappleSokol 2013), has often been supplanted by a neologism: gastrodiplomacy. This new concept refers to actions taken by governmental, private and public agencies in order to use "soft power - the power of attraction", and to promote "the art of winning hearts and minds through stomachs" (Rockower 2012, 1). Gastrodiplomacy has been, for instance, at the core of aggressive tourist policies, such as the official Global Thai Program launched in 2002 in order to erase 
Thailand's previous image as a destination for sex tourism. Recipes, restaurant décor, staff dress and atmosphere were carefully planned to sell exoticism rooted in traditional national cooking. And yet, as we see in the conclusions of this book, this cuisine was to some extent trivialized and standardized in order to accommodate the taste of international tourists. Numbers are relevant. With 25 million tourists in 2014, Thailand's success was so evident that this model was soon imitated by Taiwan (Chen 2011), South Korea and Peru (Ranta 2015, 36-8). Malaysia has also tried to tailor its national gastronomic identity in order to attract and retain its almost 26 million tourists (Omar, Karim, Bakar and Omar 2015). Many similar cases of gastrodiplomacy aim at developing tourism (Alonso and Krajsic 2013; Cohen and Avieli 2004; Gössling and Hall 2013; Harrington and Ottenbacher 2010; Sims 2009; Timothy 2016).

In Europe these policies have often combined food with history and cultural heritage. In 2005-2006 the Generalitat of Catalonia organized "L'any del manjar, cuina i gastronomia" (The Year of Food, Cuisine and Gastronomy) "to commemorate 600 years of gastronomical culture through lavish exhibits and multitudinous talks by chefs, who had already become media superstars" (Pujol 2009). In 2016 the Italian conference on Soft Power, Made in Italy and Italian Lifestyle in the World had the aim of promoting the country's image, remembering its cuisine and "not just exploiting the sector's economic potential, but trying to give due worth to that immaterial heritage of traditions and artisan expertise that may prompt foreign public opinion to reappraise Italy's role in the world". 2

A good case in point in linking marketing, branding and national cultural identity is the New Nordic Cuisine (NNC), launched in 2004 by a group of chefs. New Nordic Cuisine is trying to create a new terroir for the Nordic identity (Tholstrup Hermansen 2012), in order to challenge French hegemony over haute cuisine. It defines culinary excellence as based only on products grown in the north, which are marketed as expressing the purity, freshness, simplicity and ethics associated with the region (Haraldsdóttir and Gunnarsdóttir 2014). However, there is no real agreement on what Nordic cuisine actually means because blatant tensions have arisen between Denmark and Norway. According to Neuman and Leer (2018), Danish texts actually refer to a shared Nordic culinary identity, whereas this is the case in only 5 out of 51 (approximately $10 \%$ ) of the Swedish texts in their sample. Qualitative analysis too reveals that Nordic cuisine is for the Danes almost interchangeably connected to Danish cuisine, while in Sweden NNC's culinary excellence is construed as specifically Swedish (Neuman and Leer 2018). New Nordic Cuisine, whose flagship was the Noma restaurant in Copenhagen, was heavily financed by Denmark to the tune of no less than 25 million DKK. However, the project has its cultural side: it will develop a foundation for a future Nordic knowledge centre linking not only Sweden and Denmark, but Greenland, Norway, Iceland, the Faroe Islands and Finland as well. 
A few years before NNC was created, Denmark developed another kind of memorialization, linking national foundation myths with the need to rescue national eating habits. On 7 June 2000, the Danish Potato Council proposed in a press release to designate Valdemar's Day as Danish National Potato Day (Gold 2007, 115). Valdemar's Day - a highly respected national holiday commemorates Dannebrog, the mythical Danish flag which flew from the sky in 1219 during a battle in Estonia.

Promotion of national food in connection with national identity and rivalry on an international scale also prompted Emmanuel Macron's proposal to include the baguette in UNESCO's ICH. Explicitly presented as a reaction to the inclusion of the art of the Neapolitan pizzaiuolo, this proposal was also suggested by other impellent needs in France's political scene. Moving away from haute cuisine, it provided the opportunity to highlight the "everyday" of all French people: one single national food that could unite a country lacerated by the issue of the veil and laicité, while also going beyond specifically regional and local concerns. ${ }^{3}$

\section{Populisms and mixophobia}

Food can mirror mixophobie: the fear not just of foreignness and otherness, but of mestization. Anthropologists know well that "people who eat strikingly different foods or similar foods in different ways" might be thought to be "strikingly different, sometimes even less human" (Mintz 1985, 3). The subject is important for the way populist movements (Kaya 2019) have used the food issue. To ridicule others for their food is no new strategy: it is found in the age of early nationalism and colonialism. In recent years some European populist movements have made great play with it against migrants and Muslims. This broadly transversal phenomenon deserves attention for all its implications, such as potential leverage over a medium-low culture public and its marked communicative relevance. Significantly, both Lega Nord, who started the trend, and Alternative für Deutschland (AfD) have used food for some of their most successful electoral posters.

"Yes to polenta - No to couscous" was one of the Lega's top slogans of the 1990s (McKinley 2010). More recently the AfD used a picture of young women in classic Bavarian costume - the dirndl - to convey the message: "Trau dich, Deutschland. Burka? Ich stehe mehr auf Burgunder" (Germany, take my word for it. Burka? I prefer Burgundy wine). France followed with a slogan combining nostalgia for terroir and islamophobia in the slogan devised by Nissa Rebela in Nice (Binet 2016, 241): "Non au kebab, oui à la socca" (no to kebab, yes to socca). Incidentally, socca is not a French food: this thin, unleavened chickpea pancake is no different from the cecina eaten in Pisa or the farinata that probably originated from Genoa, but is also present in many seaports in Italy such as Livorno (where it is again called cecina) or in Palermo (panelle). Thus 
socca is not an identity marker for Provence, but quite possibly a typical food of the Mediterranean, widely present in the Maghreb, and having strong similarities with Indian specialities.

The same deconstruction of a national stereotype could be operated for couscous, found in the Sicilian gastronomic tradition thanks to Arab influence and included in the first national canon of Italian cuisine, Pellegrino Artusi's $\mathrm{La}$ scienza in cucina e l'arte di mangiar bene (Science in the Kitchen and the Art of Eating Well) (1891).

Unsurprisingly, the Front National (Shields 2014) focused on the issue of halal meat, organizing an extremely vocal campaign around the fake news that all meat in France was halal. The Identitaires, an electorally weak and yet influential French political movement, was ahead of them: in 2014 the use of food in public events and political discourse became "a weekly occurrence" (Binet 2016, 240).

Xenophobia and mixophobia are likely to rub shoulders with localism. Cuisine and agriculture can provide good material for opposing both immigration and European policies, which French peasants perceive as hostile: an argument the Lega in Italy has recently picked up once more. The mixophobic discourse (Taguieff 2015) built on reactions against Americanization: criticism of the Islaburger combined opposition to Islamization as well as to Americanization. Raoul Bové and the Confédération Paysanne gave early voice to regional food, thus linking deep criticism of globalization with "authentic" French culture. They drew on the idea of the symbiotic relationship between people and landscape (Aron 1975). Their localism is certainly not "reflexive" (Goodman, Dupuis and Goodman 2012) or sophisticated. In Nice the Identitaires organized a combat gastonomique (gastronomic combat), while in Lyon they proposed a marche des cochons (a pigs' march), banned by the local authorities. They also organized pork-based soupes identitaires, broadly attended aperitifs called Apéro saucisson et pinard where sausages and French wine were served. One expression is recurrent in their rhetoric: souche (meaning "strain" in the ethnic sense), dear to the right wing of Action Française in the early 20th century. It may be worth adding that Action Française extended to the food issue (Saillard 2010).

In Italy such issues are reflected in two episodes where there is a clear reference to local and national gastronomic heritage as a closed system. The first is the closing down (or pressure to do so) of places serving ethnic dishes. The excuse given was a desire to protect local specialities against the growing popularity of ethnic cuisines. The second issue was the question of serving pork in school canteens where Muslim pupils may be present. The guidelines from Italian Minister of Education Maria Stella Gelmini in 2011 explicitly focused on the cultural and identity aspects of food in national terms. No reference was made to food as an intercultural factor helping to create a joint and more critical awareness, as the Caritas Report on Migrants pointed out. ${ }^{4}$ Admittedly, there are on record some attempts at innovation over extracurricular school 
activities involving learning about other cultures' food: cooking dishes together including diverse traditions, or learning about their entangled history. This was again mentioned by the Caritas report drawn up prior to Expo 2015 where the theme was “Feeding the Planet. Energy for Life!" But it is certainly not enough.

In some European countries, populist movements use food in order to "other" and reject "others". Paradoxically enough, in the United Kingdom curry (Collingham 2006) and chicken tikka masala (invented in England) came close to being national dishes. By 1997 a Gallup poll announced that curry was the nation's favourite food, and in 2001 British Foreign Minister Robin Cook declared that chicken tikka masala was Britain's national dish (Laudan 2013). Food critics, however, were more sceptical: they immediately called this dish a British invention: not a sign of multiculturalism, but a demonstration of Britons' ability to transform foreign foods into their own, as Jonathan Meades wrote in the Times (21 April 2001).

\section{9 th-century food nationalisms}

Speaking of gastrodiplomacy or gastronationalism for the 19th century would certainly be an anachronism. However, it was then that food entered powerfully into both the discourse and the practice of the nation.

Until the French Revolution, food symbolized first of all power and social distinction: for the wealthy it was largely "eating to impress" (Lloyd 2015). It was in the long 19th century that food became mostly a marker of national identity, while obviously continuing to mirror relations between individuals, social groups and the state (Spang 2000). Between the 18th and 19th centuries the meaning of "you are what you eat" started to change: dishes and cuisines helped to draw or to confirm old and new, existing or imagined geopolitical and mental boundaries. This process reached back to the already existing association of "national characters" with certain foods (as also with habits and look). Between the French Revolution and the Napoleonic Wars, the opposition between Englishness and Frenchness was increasingly represented through food: the beef-eating John Bull (invented 100 years before) became extremely popular as the hero of British liberty. The supposedly hearty diet of the British was represented as the opposite pole to the elaborate, effeminate diet of the French, to the point that beef and liberty became synonymous. At the same time, in the eyes of French travellers English people became rosbifs (Rogers 2004). Much later, in the interwar years and, more precisely, in 1934, Sir Henry Dixon Kimber added the concept of race when he wrote on behalf of the Hotels and Restaurants Association of Great Britain: "The French people are, by nature, as well as by training, for the most part instinctively cooks, in the true sense of the word. The British, as a race, are not, though there are many individual exceptions. But don't forget - different nationalities have different tastes, and employ different methods" (quoted in Mennell $1985,279)$. 
In the early 19th century food started to identify the "we" of the invented national community against the "others". This represented a sharp turn from its previous use to signify divisions within society. It was then that the idea of the "middling cuisines" started to gain ground. According to Laudan, the "yawning gap between the food of the rich and the powerful and the food of everyone else within the state was diminishing. It was replaced by a different gap, a gap between the states where the shift to middling cuisines had occurred and the states that retained a sharp distinction between high and humble cuisines" (Laudan 2013, chapter 8). By the end of the 19th century, however, national cuisines were established in North America, Europe, Latin America and Japan, and were discussed in India and in various parts of the Ottoman Empire.

National thinking prompted the construction of national cuisines. This phenomenon should be read in the context of policies which promoted patrimonialization, as it was labelled in France, where the concept of heritage was born in the crucial years of the French Revolution. The new system of "museum, nation and heritage" (Poulot 1997) implied a deep change of perspective, which also directly affected the perception of cuisine. In his book Paris à table (1846) Eugène Briefault' declared that "la cuisine d'un peuple est le témoin exacte de sa civilisation" (a people's cuisine bears exact witness to its civilization) (quoted in Ory 1992, 823) and confirmed that the nation and its cuisine were one. In the Grande Nation and especially in Paris, restaurants were invented, cookbooks were published, the excellence of cuisine was emphasized and cooks policed the taste (Davis 2013). They became priests in a "properly national celebration" and looked for the roots of the nation, as did archaeologists and historians (Rowley 2006, 223).

Cuisine became an object of catalogues aiming at preservation, following the blueprint of the catalogues and musealizing of art heritage. In France shortly after the Revolution - that is, when the first museum of the monuments of the nation was created - the first inventory of the country's food was started as well.

I suggest we read the construction of a gastronomic identity as a policy similar to the creation of museums and centres for history studies. Research on this issue is still scant. However, there are interesting traces which ought to be followed up regarding more than one country. In 1859, shortly before Italian unification, scholars in Emilia creating one of the first regional institutions for the publication of historical sources urged the need to publish not only collections of local monuments and documents, but, equally important, to prepare inventories of bread shapes and special foods of the various provinces (Porciani 2018). In Spain in the 1870s, shortly after the foundation of the National Archaeological Museum dedicated to the protection, classification and exhibition of archaeological but also ethnographical items (Esteban deVega 2010, 126), a discussion about the gastronomic identity of the country was started by the father of national folklore, Antonio Machado y Alvarez. It was carried on under the auspices of the Centro de Estudios Historicos, founded in 1910, where historians and other scholars worked at a catalogue of historic 
Spanish traditions. The idea behind this research was that classic Spanish cuisine, enriched by many regional traditions, had been "slandered, forgotten and supplanted by the foreign fashion of French cuisine" (Ingram 2012, 9) and had to be rescued: thus Spain experienced its own version of gastronationalism (Riera i Melis 2004, 775).

While no national museum of food was created, the great international and national exhibitions which began in London in 1851 acted as a kind of Ersatz placing national foods on display (Scholliers and Teughels 2015). Such pavilions presenting food fall somewhat short of a museum but may at least be seen as temporary shows of food products, not only for commercial reasons, but also in order to present the variety of the various countries' edible heritage (Tellström, Gustafson and Lindgren 2008).

While shortly after the Revolution France was starting to recollect its food heritage, on the other side of the Atlantic Ocean the new republic of the United States of America in turn began shaping its national identity through culinary discourse and the unifying and civilizing practices of home cooking. After the American Civil War, the 1876 centennial encouraged further debates on national cuisine (Laudan 2013). American authors tried from very early on to define their national cuisine in opposition to Britain's. Corn "became a political instrument for self-definition and resistance, and laid the foundation for a republican cuisine" (Vester 2015). In neighbouring Canada, a cookbook written by the ladies of Toronto in 1878 complained that Canadians had no national dish to distinguish themselves from the British.

In Europe, after the defeat of the double monarchy in 1866, Hungarians nationalized goulasch (Metro-Roland 2013), a southern speciality until then ignored and considered vulgar. There was no question of sharing their culinary marker with the German victors (Rowley 2006, 324). Shortly after independence (1878), Romania also published its first book of recipes in the national language. Foreign names defining culinary specialities were avoided, especially on important events. In 1870s Spain criticisms were voiced of state banquets whose menus were written in bad French and not in Spanish. The same happened in Germany, where the Kaiser decreed that as far as possible imperial menus should be written in German (Heinzelmann 2014, 209). In this respect, Italy represents an exception, since the court cuisine remained French oriented while it was middle-class nationalism that pressed for a national cuisine (Montanari and Capatti 2003). In almost every country popular plates were named after kings, princes and princesses - the beloved icons of the nation. In Italy we find pizza Margherita (D'Achille 2017) and in England we see Prince Albert Pudding, while in Majorca the recipe of the sobressada was attributed to King Martin I of Aragon (Rowley 2006, 326). In Russia, where Tsar Nicholas I aimed at state-oriented patriotism focusing on "Russianness" and did not welcome "foreign" behaviour or cultures (Smith 2009), the topic of cuisine fell into the field of tension between Slavophiles and Westernizers. Faddej Bulgarin, in his popular weekly column in the Ekonom, praised Russian dishes as "simple, 
healthy, without any spices, without artifice, moral" as opposed to foreign food and spices (Smith 2009).

The deep divide between homely middle-class Russian food and foreign gastronomic foods was reflected in cookbooks. Restaurants followed. In Latvia at the beginning of the 19th century the top restaurants only served international cuisine, but after independence they started to serve only national cuisine.

Italy was probably an exception here: this "latecomer" to nation-building never developed a clear "national" culinary character. In fact, the acceptance of a plurality of traditions, already featured even in early modern cookbooks (Montanari 2013), was stressed even more in the years of annexation to Piedmont, when fear of standardization and Piedmontization was widespread. Parliamentary novels of post-unification Italy featured members of Parliament discussing the need to unify the national cuisine but also stressed the difficulty of doing so (quoted in La Cecla 2016, 51-2), while Pellegrino Artusi did not try to impose one gastronomic style but carefully noted and accepted diversity, as explained in the conclusion of this book.

\section{Women and cookbooks: gender and culinary nationalism}

Cuisine became one of the pillars of the new heritage community. At the centre of this community were women. Not by chance Marie-Antoine Carême began his L'Art de la cuisine française au dix-neuvième siècle (1833) with a discussion of pot-au-feu (boiled beef), the dish that holds the key to the French worker's diet and also lays the foundation for French cuisine as a whole, and began not with a recipe but with an analysis that details exactly what happens when the housewife sets her pot on the fire (Parkhurst Ferguson 2004, 377). The nation may have been masculinized, given the centrality of the discourse on male bourgeois citizens and soldiers, but it was also feminized and familialized (Porciani 2002).

In the United States the close link between family and nation - reinforced thanks to the founding myth of American motherhood - was reaffirmed in the kitchen (Vester 2015). From independence on, the civilizing and domesticating role of middle-class white women in the United States was transmitted by textbooks of domestic economy written for women by women. Catherine Beecher's The American Woman's Home criticized British cuisine and, while not despising the French, did not fail to mention the "good patriots" or the good culinary habits of the grandmothers (Beecher 1869, 171, 176). In 1846 Sarah Josepha Hale launched a campaign to celebrate Thanksgiving as the national holiday commemorating unification, expansion and inclusion around the dinner table and the turkey. Godey's Lady's Book (1865) - the American woman's bible of domestic science that would see out the century - urged its readers to support this influential ritual rooted in domestic life (Porciani 2008). Many 
of these cookbooks were written by Presbyterian churchwomen, prefaced by ministers and sold for charity (Laudan 2013).

In Europe women wrote cookbooks almost everywhere (Montanari 2013): Magdalena Dobrumila Rettigovà provided Czech cuisine with its bible, and Katharina Prato was the author of a monumental cookbook running to more than 700 pages. They were not alone, as Catherine Horel points out in this volume (Chapter 8). In Denmark, recipe books written by women and focusing on the perception of nation-building in the throes of heavy territorial losses promoted the consumption of Danish products and the education of good citizens. Thus they voiced women's need to be "useful for our fatherland". It is therefore not surprising that cookbook authors were explicit about not using foreign names (Gold 2007, 98-102): a choice made elsewhere too, and similar to the deep criticism of "foreign" nannies for the young generation in many countries.

In Russia cookbooks were also often written by women: the most popular cookbook author in the country was probably K.A. Andreeva, who labelled herself as an "experienced Russian housewife" (Smith 2012, 456).

"[A] cookbook that consisted of nothing but rules for various dishes would be an unpopular cookbook indeed. Even the root of recipe - the Latin recipere implies an exchange, a giver and a receiver. Like a story, a recipe needs a recommendation, a context, a point, a reason to be" (Roy 2002, 478). Some of them provide narratives and even a feminine genealogy (the cooking of the mother or the grandmother). Others constitute a sort of autobiography of the nation, and are even chosen as national icons. Three years after publication of the first historical study ever written in Lithuanian (Selenis 2010), in 1845, it was a (noble) woman, Anna Ciundziwicka, who oriented greater Lithuanian culinary history with a book titled Lithuanian Housewife, which was followed six years later by Wincentyna Zawadzka's Lithuanian Housewife (Belyi 2013). However, the first cookbook in the Lithuanian language (again titled Lithuanian Housewife and likewise authored by a woman) was not published until 1893. The importance as well as persistence of this national turn should not be exaggerated: in relation to food the elite of the new interwar Lithuanian Republic concentrated on other issues - less important for the focus of this book - but rational, scientifically correct and healthy food preparation indebted to the Western model was not the least important of them.

At the turn of the century, when a further shift took place - from the Kulturnation to the ethnic nation - women were once more at the centre of the picture. In 1894 Alfred Suzanne, introducing his La cuisine anglaise et la pâtisserie, wrote: "In France women need not learn cookery. It is inborn" (quoted in Saillard 2014). Action Française had already devoted attention to French cooking, but it was in the interwar years that such statements took a clear step further. In his novel on La vie et la passion de Dodin-Bouffant, gourmet (1924), the historian and writer Marcel Rouff declared: "la gastronomie est innée dans la race" (gastronomy is innate to the race). The model at this point 
is clearly the peasant woman "de souche" who never learned cooking at school or in books, because "elle la savait de naissance et par atavisme" (she knew it from birth, atavistically) (quoted in Rowley 2006, 338). This statement recalls the widespread discourse on women's ancestral memory in the same period (Porciani 2008). In the 1930s, while praising the excellence of French cuisine, the middle-class women's magazine Elle cautiously presented a few exotic dishes, introducing them explicitly as "alien” (Régnier 2005, 3).

In the interwar republic it was the Lithuanian Women's Catholic Association that published a magazine and promoted a book of recipes which described the main dishes of the culinary heritage of the four principal ethnic groups, and published the oldest recipe for Lithuanian zeppelins (cepelinai): potatoes stuffed with chopped meat (Belyi 2013), while in the neighbouring Belarus republic the most vivid contribution to the idea of Belorussian culinary heritage was The New Land by Yakub Kolas, an epic poem in Belorussian which described peasant meals at length. The culinary roots were to be found in peasant life.

In Serbia, Slovenia and Croatia women also wrote national cookbooks, carefully differentiating them from those drawing on foreign sources. None of them, however, mirrored a Yugoslavian identity. It was only in socialist Yugoslavia that the former head chef for Tito, Olga Novak-Markovič, tried to blend the nation's dishes into a cuisine characteristic of Yugoslavia as a whole (Bracewell 2012; Saillard 2014).

In Spain, after the First World War, novelist Emilia Pardo Bazan "pleaded for the nationalization of domestic practices" (Storm 2016, 184) and "urged her listeners to thoroughly hispanicize their homes, beginning with the cuisine" (Gutiérrez 2017) and argued that they should cook Spanish dishes, in line with which she published La cocina antigua española. Gastronationalism became intense under Franco: only from the late 1960s on did regional or international gastronomic traditions start to re-emerge (Anderson 2013a, 2013b; Ingram 2012; Riera i Melis 2004, 775, 780).

Clearly, gender, nation and food form a complex strand. National dishes especially if related to fire and open-air cooking - often seem connected with masculinity: this is so with the barbecue or the Mexican barbacoa. This issue is extremely important in connection with dishes perceived as national. Barbecuing is also a beloved male activity of Israeli Jews celebrating the nation's independence day (Avieli 2013) while paella too was originally a dish prepared by men on an open fire. It only later became part of women's cuisine when it was brought inside and cooked in the kitchen (Duhart and Medina 2007; Guardiola y Ortiz 1972).

Useful prompts for thinking about food-nation-gender tie-ups also emerge from new case studies focusing on the perception and custody of traditional identity-linked factors in relation to conflict over statehood. Among Israel's Palestinians only the menfolk cook in public establishments, in which Palestinian women do not figure at all. These Palestinian male cooks prefer to serve dishes not directly connected to their own tradition. For traditional 
cooking, the perceived heritage of the Palestinian people is the women's province within the family nucleus, as though it were women, retaining the secret recipes and food customs of tradition, who cultivate the nation inside the private, though political, domain of the home. They refuse to let it be commodified in restaurants of outsiders, where it would so easily get shared or watered down: in a word, dispersed or perverted. As Gvion writes, it is partly by preserving a distinction between home cooking and food consumed in public places that Palestinians express their resistance to the status they have been given in Israeli society and "become active social agents engaged in controlling the appropriation and modification of Palestinian food by Jewish culinary agents" (Gvion 2011, 411). Studies on masculinity start focusing on the issue of food (Neuman 2017; Neuman and Fjellström 2014). As cooking shows are reaching the status of icons, scholars have also started to reflect on the image of masculinity that they convey (Leer 2016).

\section{Coda: about this book}

The story of food nowadays associated with one nation state is often a story of remote transfers owing to usually overlooked long-distance travel and migrations: when we eat tempura in a European Japanese restaurant looking for something new, we do not think that Japan adopted tempura from Portuguese visitors and returned it to Europe with migrants of its own (Fernández-Armesto and Sacks 2012).

Exchanges have always marked the history of ingredients and cuisines. Hence, it is important to avoid any temptation of methodological nationalism which might encourage one to rethink cooking traditions within the nation states' borders. Contacts and transfers took place right from ancient times: the ones attested within the Roman Empire were not the first.

In this book Massimo Montanari focuses on the integration of Europe's culinary models in the Middle Ages and on their syncretism. The opposition between food regimes of different religious groups was apparently marked by clear-cut boundaries: Christians had a well-defined liturgical year interspersed with periods of fasting, Muslims had Ramadan and Jews ate special foods for specific festivities. The interdicts on pork for Muslims and on pork and other kinds of meat for Jews strongly differentiated their cooking. Yet recent studies on the eating habits and identity of Jewish communities point out not only the dynamic, porous and constantly evolving character of their recipes and the process of differentiation of some Jewish dishes from "local" cuisines (Roden 1974), but also the many changes and hybridization of original recipes of distinct Jewish groups, which could not always follow their tradition because they had to use what was locally available (Toaff 2004).

The crusades fostered new eating experiences and culinary habits. Much more decisive, however, was the Columbian exchange (Crosby 1972), which opened the way to many culinary discoveries (Earle 2012; Pérez Samper 2012) 
and reciprocal transfers from the old world to the new and beyond, as triangulation through Africa makes clear. The turkey's French name, dinde - that is, "d'Inde" (from the West Indies) - still bears evidence of its exotic origin. At first it was only eaten in well-defined geographic areas such as Genoa and eastern Iberia, and especially in specific social milieus (Genoese merchants and Spanish nobility), but it was soon incorporated in many European diets. However, it took time before some of the plants and animals introduced on either side became widely accepted and were incorporated in previous eating regimes. The history of the potato and its slow reception is exemplary in this respect. It was not until the mid-17th century, after the destruction, reconstruction and reintegration of food in the new world and in Africa, Europe and Asia, that new animals and edible plants were adopted in hybrid cuisines (Mintz and Friedmann 2004, 421). The fact that new cereals and vegetables reached Europe did not make them immediately accepted or popular there when they first arrived. Corn and tomatoes made their way through Catalonia and western Liguria before becoming core components of many recipes in southern France and Italy.

The long 19th century was much more an age of empires than of nations and nation states (Osterhammel 2014,392). It is impossible to imagine Britain without the empire. Throughout the long 19th century edibles constituted the majority of the value and weight of Britain's imperial trade (Bickham 2008, 72). These products coming from the empire penetrated the daily life of men and women. Their advertisements were more pervasive than any other print media. Not only images of the British colonies and imperial trade abounded in British advertisements for empire-related foods: "Britannia, the symbolic embodiment of Britain, appears regularly with her spear and shield before bowing imperial subjects offering imperial foods and goods as a form of tribute" (Bickham 2008, 81-92). British cooking was marked by an increasing presence of "Currey the India way", which appeared for the first time in Hannah Glasse's Art of Cookery Made Plain and Easy (1747). With the "increasing racialization of the Raj after 1857, the body of British official in India became an even more powerful sign of 'Britishness' and diet and dress become, accordingly, cultural sites on which a sense of bodily difference between the British and their Indian subjects was maintained" (Sengupta 2010, 84). The flavours of Indian cuisine and the spices brought back by the East India Company's nabobs (Collingham 2006; Colquhoun 2011) were soon transformed into new recipes and foods: curry was rapidly interpreted as a ready mixture of spices soon to be called "Curry powder". This mixture was sold as early as 1784 in London and soon curry became a national dish. In spite of all these entanglements, however, British cooking apparently remained extremely conservative until the 1960s: only then did restaurants run by immigrants from Italy, China or the Indian subcontinent start to become popular (Mason 2004).

Innovative and even cosmopolitan restaurants (Assael 2013), together with ethnic and colonial shops or the large stores which started to appear at the 
turn of the 20th century especially in the metropolis and capital cities, started to offer a variety of exotic products, in implicit opposition with the market halls, so deeply connected with local food and recently turned into heritage and memory places (Fava, Garcia, Plana and Garrido 2016). In food exchanges empires were crucial: they introduced innovations and forced a metropolitan taste on peripheral areas, as well as providing institutional and geopolitical opportunities for mobility of merchants, civil servants and the armed forces, who took with them cookbooks, cooks and maids, thus hybridizing culinary traditions, as Samanc1 (Chapter 9) and Horel (Chapter 8) point out in this book.

No less important, however, were various other kinds of people on the move. Travellers and later tourists imported new tastes and opened the path not only to "typical" or "ethnic" restaurants in Europe, but to a reshaping of exotic cuisines which adapted to their consumers' taste and expectations. Much later, students, especially after 1968 and increasingly with the Erasmus and Overseas programmes, have also contributed to such hybridization of gastronomic cultures and eating habits.

Diasporas (Mintz 2008) and exiles (Fernández-Armesto and Sacks 2012) in turn introduced and popularized new foods, and still do. So too did various waves of emigration and immigration (Beer 2014). In recent times, these experiences also started to be mirrored in some temporary or permanent exhibitions, complementing the static and often national approach of many museums dealing with food. In fact, museums can turn into visual and sensory experience the notion of what food was and is. They often suggest nostalgia for a mythical past, prior to industrialization, globalization, and what is perceived altogether as decline. Sometimes, however, they try to play their role in the field of public history and take account of the historian's work. In Plymouth Plantation historians have documented 17th-century English and Native American foodways, have given attention to those dynamics that changed both groups as a result of their interaction, and have "deconstructed and dismissed the mythologies central to a nationalist ideology, and have reinterpreted an early meeting, commonly and mistakenly referred to as 'the First Thanksgiving', between Wampanoags and Pilgrims. The resultant recasting successfully offered through food history a new context for the interpretation of Native American history, settler history, and environmental history" (Green 2012, 86). This attention to the new history of food is to some extent mirrored in the Brussels House of European History, which provides a concise presentation of food transfers within European countries and across the Mediterranean. Through displays that focus on culinary cultures, museums - as Susannah Eckersley shows in this book (Chapter 6) - can also answer to a desire for public recognition of difficult past times and deal with themes of multiculturalism, migration and intercultural contact, providing a kind of "safe space" to explore differences otherwise difficult to deal with.

Unsurprisingly, the topic of migrations has largely been investigated for Italian Americans in connection with the image of the country, in studies 
which are relevant to the approach of this book (Caldognetto 2014; Cinotto 2017; Cinotto, Canepari and Regnard-Drouot 2016; Corti 1998; Diner 2001; Gabaccia 1998; Scarpellini 2016). Italians in the United States of the late 19th and early 20th centuries emphasized the link between their products and some of their nation's icons, projecting the pride of a Kulturnation onto commodities. Garibaldi's immense popularity in 19th-century England explains the name of popular cookies, still produced today. One olive oil brand was soon named after Dante, while advertising of other produce displayed images of famous Italian monuments: a process that also occurred in Italy, as Paolo Capuzzo points out in this book (Chapter 4).

In closing this introduction, I would like to refer to recent works which highlight the use of national heritage in order to promote not only food, but restaurants. Maren Möhring studied the evocative power of monuments in the prints and pictures adorning the walls of Italian restaurants in Germany from the 1950s onwards in an attempt to reconstruct an Italian atmosphere (Möhring 2012, 258, 267-8). Further investigations of the commercial strategies of governments, producers and tourist agencies would certainly help us to understand the intertwining and overlapping of artistic and food heritages that occurs in branding. It was not possible to further develop this issue here, neither was it possible to explore the role played - albeit at a very different level - by exiles: in this book this topic is only touched on by Tolomelli (Chapter 5).

From different points of view this introduction and the 11 chapters of this book investigate the interweaving of discourses on food and to a varying extent cooking practices, heritagization and nationalism. These narratives grew out of largely invented foundation myths and traditions of individualism and nationality. The authors of this book do not share the framework of unreflective nationalism. Thus we have chosen to avoid chapters focusing on individual countries: Paolo Capuzzo's contribution (Chapter 4) - mostly but not exclusively on Italy - is thus an exception: its importance lies in exploring the dynamics and political nature of the regional or local dimension in a 200-year span from nationalism, through Fascism, down to the mass television culture and the miracolo economico (the Italian economic miracle or boom). Instead of focusing on individual countries, we have chosen to cast light on transnational spaces, from medieval Europe to the empires. We have drawn attention to the global scene which quality labels and intangible heritage impact (Parasecoli, Chapter 3, and Di Fiore, Chapter 2), conscious that even when Europe is at the core of our research, it is a Europe with porous and open borders, increasingly connected.

In many ways we have insisted on one point: that place-bound formal heritagization may present problems. Di Fiore suggests that such processes often minimize history and change (in the conclusion to this book Massimo Montanari and I have called this time) in favour of place-bound invented traditions (in the conclusion we have called this place). History and geography are the historian's eyes, from Herodotus onwards. It is important to map 
change - persistence but most of all innovations in a geography free from constraints: a geography which does not passively mirror the methodological nationalism of nation-state borders, but opens up to dynamism.

Many themes recur in this book's various chapters. Gender is one of them, and intersects with this introduction as well as Williot's (Chapter 10) and Di Fiore's (Chapter 2) contributions and the chapters on empires (Chapters 3 and 4), on 1968 (Chapter 5) and on museums (Chapter 6).

Class is certainly another issue that crosses most of the chapters of this book, including this introduction. National imagination created around food, and eventually a national cuisine, tended to overshadow the fact that often the "national diet" was in fact not the same for everybody: poor people had access to a limited supply of food and were certainly not the intended public of recipe books. Only in post-war situations and countries with wide-scale literacy was food shortage addressed, albeit indirectly, and the authors of cookbooks did not refrain from pointing out that certain ingredients needed in cooking typical dishes were expensive and beyond some people's means.

Differences of class and milieu intersecting with local peculiarities have always been relevant. Massimo Montanari points out that the lower classes were for a long time limited in their consumption to what was produced in the area. It was the signori (the nobility and the gentry) who were not so restricted: there was a clear gap between what the courts and the aristocracy ate and what the workers could afford: often one single food, and not even enough of it. Wine conquered the beer countries fairly early, but was only drunk by the elites; Catherine Horel (Chapter 8) points out that there was - as expected - a great difference between what the lower classes and the upper classes drank.

Catherine Horel highlights also the mobility of civil servants and cooks, while peasants were sedentary. Having access only to local food, they were more conservative in taste and eating habits. The urban middle classes were more experimental, especially in an empire. In a different context it was middle-class stateless refugees from the former Russian Empire who created a distinctive vibrant consumer economy in international cities and were active in opening restaurants and importing new food heritage to such places as cosmopolitan Shanghai with its community of merchants and traders. It was the middle classes that ate in Shanghai restaurants in the 1920s and 1930s, as Katya Knyazeva remarks (Chapter 11). Social stratification is also considered in Capuzzo's contribution (Chapter 4), which focuses especially on the role of the middle classes. Fabio Parasecoli (Chapter 3) suggests we should connect social milieus with taste. Features that in the past were a cause for shame, such as the simplicity of dishes, the rusticity of ingredients and the connection with rural and workingclass social environments, have turned into major advantages in the process of re-evaluation that characterizes contemporary food culture.

Essential, ethnic food rooted in a single locality hardly exists. And yet nostalgia is a central topic to many of the chapters of this book. As we have briefly recalled, however, exchanges were a persistent and crucial factor, as has been 
the role of diasporas, colonization and decolonization, commercial and colonial trade (Knyazeva, Chapter 11), older and more recent mass migrations, but also movements like those of 1968, where a new generation became increasingly open and experimental, and its criticism of traditional foodways revealed scope for experiments perceived and labelled as new on both sides of the Atlantic (Tolomelli, Chapter 5). Each of them contributed to the food's geteilte Geschichte.

Many chapters of this book emphasize not only the well-known opposition between town and country, but more specifically the role of capital cities such as Paris, the capital not only of France, but also of the long-lasting French hegemony over haute cuisine;Vienna and Istanbul were true melting pots, but so too were important harbours in Europe, in the colonies and in the imperial ambit. Fiume is a good case in point.

Tensions between local and national on one hand, and global on the other, are present in various chapters: they could be read as a fil rouge running throughout this volume, from this introduction to Di Fiore's contribution (Chapter 2) which points out that in UNESCO candidature local becomes national on the global scene - to the chapter authored by Fabio Parasecoli (Chapter 3).

The chapters of this book implicitly allude to some further common themes. As a parting shot to this introduction, I invite readers to spot these, and to read this book both as a summing up of three fertile decades of study and as a springboard for other more specific research.

\section{Notes}

1 UNESCO nomination file number 01063 for inscription on the representative list of the Intangible Cultural Heritage of Humanity.

2 www.gamberorosso.it/it/news/1026133-1-istituto-nomisma-spiega-all-italia-cos-ela-gastro-diplomazia-il-soft-power-di-cibo-e-cucina accessed December 2018.

3 www.20minutes.fr/societe/2201303-20180113-unesco-emmanuel-macronsouhaite-baguette-inscrite-patrimoine-mondial-humanite; http://gastronomiquementvotre.blogspot.com/2008/09/le-patrimoine-alimentaire-definition.html accessed December 2018.

4 Caritas e migrantes. XXIV rapporto immigrazione e sviluppo: http://inmigration.caritas. it/sites/default/files/2016-09/XXIV\%20Rapporto\%20Immigrazione\%202014.pdf accessed December 2018.

\section{References}

Adell, N., Bendix, R., Bortolotto, C. and Tauschek, M. (2016) "Introduction", in N. Adell, R. Bendix, C. Bortolotto and M. Tauschek (eds), Between Imagined Communities and Communities of Practice Participation, Territory and the Making of Heritage, Göttingen: Göttingen University Press, 7-24.

Alonso, A. and Krajsic, V. (2013) "Food heritage down under: olive growers as Mediterranean 'food ambassadors", Journal of Heritage Tourism 8(2-3): 158-71. 
Anderson, L. (2013a) Cooking Up the Nation. Spanish Culinary Texts and Culinary Nationalization in the Late Nineteenth and Early Twentieth Century, Woodbridge: Tamesis.

Anderson, L. (2013b) “The unity and diversity of La olla podrida: an autochthonous model of Spanish culinary nationalism", Journal of Spanish Cultural Studies 14(4), 400-14.

Appadurai,A. (1996) "Global ethnoscapes: notes and queries for a transnational anthropology”, in A. Appadurai, Modernity at Large: Cultural Dimensions of Globalization, Minneapolis: University of Minnesota Press, 48-65.

Ariel, A. (2012) “The hummus wars”, Gastronomica 12(1): 34.

Aron, J.P. (1975) The Art of Eating in France: Manners and Menus in the Nineteenth Century, London: Peter Owen.

Assael B. (2013) "Gastro-cosmopolitanism and the restaurant in late Victorian and Edwardian London”, Historical Journal 56(3): 681-706.

Avieli, N. (2013) “Grilled nationalism”, Food, Culture \& Society 16(2): 301-20.

Aykan, A. (2016) “The politics of intangible heritage and food fights in Western Asia”, International Journal of Heritage Studies 22(10): 799-810.

Barham, E. (2003) "Translating terroir: the global challenge of French AOC labeling”, Journal of Rural Studies 19: 127-38.

Barthes, R. (1961) "Pour une psycho-sociologie de l'alimentation contemporaine", Annales 16(5): 977-86.

Baumann, Z. (2000) Liquid Modernity, Cambridge: Polity Press.

Beecher, C. (1869) A Treatise on Domestic Economy, for the Use of Young Ladies at Home, and at School, Boston, MA: T.H.Webb.

Beer, M. (2014) Über den tellerrand geschaut. Migration und Ernährung in historischer Perspektive (18. bis 20. Jahrhundert), Essen: Klartext.

Bendix, R., Eggert, A. and Peselmann, A. (eds) (2012) Heritage Regimes and the State, Göttingen: Universitätsverlag Göttingen.

Bessière, J. (2001) Valorisation du patrimoine gastronomique et développement territorial: le Haut Plateau de l'Aubrac, Le Pays de Roquefort et le Périgord Noir, Paris: L'Harmattan.

Bessière, J. (2010) "Patrimoine alimentaire et innovations. Essai d'analyse typologique sur trois territoires de la Région Midi-Pyrénées", ISDA. https://hal.archives-ouvertes.fr/ hal-00521740

Bessière, J. and Tibère, L. (2010) L'innovation dans les processus de valorisation des patrimoines alimentaires en espace rural. Étude pour la mise en place d'outils de gestion et d'accompagnement, Versailles: Editions Quae.

Biasin, G. (1991) I sapori della modernità. Cibo e romanzo, Bologna: Il Mulino.

Bickham, T. (2008) "Eating the empire: intersections of food, cookery and imperialism in eighteenth century Britain", Past and Present 198: 71-109.

Billig, M. (1995) Banal Nationalism, London: SAGE.

Binet, L. (2016) “'Touche pas à mon pain au chocolat!' The theme of food in current French political discourses", Modern \& Contemporary France 24(3): 239-52.

Blom, I., Hagemann, K. and Hall, C. (2000) Gendered Nations: Nationalisms and Gender Order in the Long Nineteenth Century, Oxford-New York: Berg.

Boym, S. (2001) The Future of Nostalgia, New York: Basic Books. 
Bracewell, W. (2012) "Eating up Yugoslavia: cookbooks and consumption in socialist Yugoslavia", in P. Bren and M. Neuburger (eds), Communism Unwrapped. Consumption in Cold War Eastern Europe, New York: Oxford University Press, 169-96.

Caldognetto, M.L. (2014) "Storia e memoria di sapori e saperi: la forza del territorio nella cultura del cibo italiano oltre frontiera", in M.L. Caldognetto and L. Campanale (eds), Tra innovazione e tradizione, un itinerario possibile, Luxembourg: Convivium, 179-229.

Chapple-Sokol, S. (2013) "Culinary diplomacy: breaking bread to win hearts and minds", The Hague Journal of Diplomacy 8: 161-83.

Chen,Y.-J. (2011) "Ethnic politics in the framing of national cuisine", Food, Culture and Society 14(3): 315-33.

Chong, J. (2012) "Mine, yours or ours? The Indonesia-Malaysia disputes over shared cultural heritage", SOJOURN: Journal of Social Issues in Southeast Asia 27(1): 1-53.

Cinotto, S. (2017) "Immigrant tastemakers: Italian cookbook writers and the transnational formation of taste in the postindustrial United States, 1973-2000", in J. Sciorra and L. Ruberto (eds), New Italian Migrations to the United States, Vol. 2, Urbana: University of Illinois Press, 139-66.

Cinotto, S., Canepari, E. and Regnard-Drouot C. (2016) Food, Migration, and Mobility in Historical Perspective: Nineteenth to Twenty-First Century, special issue, Quaderni Storici 151.

Clough, E. (2015) "The politics of food labeling and certification", in R.J. Herring (ed.), The Oxford Handbook of Food, Politics, and Society, Oxford: Oxford University Press.

Cohen, E. and Avieli, N. (2004) "Food in tourism: attraction and impediment", Annals of Tourism Research 31(4): 755-78.

Collingham, L. (2006) Curry: A Tale of Cooks and Conquerors, New York: Oxford University Press.

Colquhoun, K. (2011) Taste: The Story of Britain through Its Cooking, London: Bloomsbury.

Corti, P. (1998) "Emigrazione e consuetudini alimentari. L'esperienza di una catena migratoria", in Storia d'Italia, Annali, vol. 13, Turin: Einaudi, 681-719.

Counihan, C. (1999) The Anthropology of Food and Body: Gender, Meaning and Power, New York: Routledge.

Counihan, C. and Kaplan S.L. (1998) Food and Gender: Identity and Power, Amsterdam: Harwood Academic Publishers.

Crosby, A. (1972) The Columbian Exchange: Biological and Cultural Consequences of 1492, Westport, CT: Greenwood Publishing Group.

Csergo, J. (2016) La gastronomie est-elle une merchandise culturelle comme une autre? La gastronomie française à l'UNESCO: histoire et enjeux, Laballery, Paris: Menu Fretin.

Cwierta, K.J. (2006) Modern Japanese Cuisine. Food, Power and National Identity, London: Reaktion Books.

D’Achille, P. (2017) Che pizza!, Bologna: Il Mulino.

Davis J.J. (2013) Defining Culinary Authority: The Transformation of Cooking in France, 1650-1832, Baton Rouge: Louisiana State University Press.

de Soucey, M. (2010) "Gastronationalism. Food traditions and authenticity politics in the European Union", American Sociological Review 75(3): 432-55.

Delfosse, C. (1997) "Noms de pays et produits du terroir: enjeux des dénominations géographiques”, Espace géographique 26(3): 222-30. 
Delfosse, C. (ed.) (2011) La mode du terroir et les produits alimentaires, Paris: Les Indes savantes.

Demossier, M. (2016) "The Europeanization of terroir: consuming place, tradition and authenticity", in R. Friedman and M. Thiel, (eds), European Identity and Culture: Narratives of Transnational Belonging, London-New York: Routledge, 119-36.

Di Fiore, L. (2018a) "Patrimoni di origine protetta. Le procedure di Food Labelling nelle istituzioni internazionali all'incrocio tra nazionale, globale e locale", Storicamente 14(2): doi: 10.12977/stor692.

Di Fiore,L. (2018b) “Bibliography 'Food as Heritage”, Storicamente 14(3): doi: 10.12977/ stor696.

Di Giovine, M. and Brulotte, R. (2014) "Introduction: food and foodways as cultural heritage", in M. di Giovine and R. Brulotte (eds), Edible Identities: Food as Cultural Heritage (Heritage, Culture and Identity), New York: Routledge, 1-28.

Diner, H.R. (2001) Hungering for America: Italian, Irish, and Jewish Foodways in the Age of Migration, Cambridge, MA: Harvard University Press.

Douglas, M. (1966) Purity and Danger: An Analysis of Concepts of Pollution and Taboo, London: Routledge.

Duhart, F. and Medina, F. (2007) "La paella domestiquée (Espagne, France). Rèflexions sur l'entrée en cuisine d'n plat venu des champs", in G. Cazes-Valette (ed.), Faire la cuisine. Analyses pluridisciplinaires d'un nouvel espace de modernité, Paris: OCHA, 162-8.

Durand, G. (1992) "La vigne et le vin”, in P. Nora (ed.), Les lieux de mémoire, vol. 3.2, Paris: Gallimard, 784-821.

Duruz, J. (1999) "Food as nostalgia: eating the fifties and sixties", Australian Historical Studies 29(113): 231-50.

Earle, R. (2012) The Body of the Conquistador: Food, Race and Colonial Experience in Spanish America, Cambridge: Cambridge University Press.

Esteban de Vega, M. (2010) "Spain”, in I. Porciani and L. Raphael (eds), Atlas of European Historiography. The Making of a Profession 1800-2005, Basingstoke: Palgrave Macmillan.

Evans E. (1942) Irish Heritage. The Landscape, the People and Their Work, Dundalk: Dundalgan Press.

Everett, S. and Aitchison, C. (2008) "The role of food tourism in sustaining regional identity: a case study of Cornwall, south west England", Journal of Sustainable Tourism 16(2): 150-67.

Fava, N., Garcia, M., Plana, L. and Garrido, R. (2016) “Food public markets as cultural capital: Girona province", in C. Hein (ed.), International Planning History Society Proceedings, 17th IPHS Conference, History-Urbanism-Resilience, Tu Delft Open. doi: http://dx.doi. org/10.7480/iphs.2016.3.1253

Fernández-Armesto, F. and Sacks, B. (2012) “The global exchange of food and drugs", in F. Trentmann (ed.), The Oxford Handbook of the History of Consumption, OxfordNew York: Oxford University Press, 127-44.

Fischler, C. (1988) "Food, self and identity", Social Science Information 27: 275-93.

Flandrin, J.L. (1999) "Dietary choices and culinary technique, 1500-1800", in J.L. Flandrin and M. Montanari (eds), Food. A Culinary History, New York: Columbia University Press, 403-17.

Flandrin, J.L. (1992) Chronique de Platine: pour une gastronomie historique, Paris: Jacob. 
Flandrin, J.L. (2000) La blanquette de veau: histoire d'un plat bourgeois, Paris: Jean-Paul Rocher.

Fox, R. (2007) "Reinventing the gastronomic identity of Croatian tourist destinations", International Journal of Hospitality Management 26(3): 546-59.

Frattini, D. (2017) "Israele, la disfida dello 'zataar' l'erba dell'anima palestinese" Corriere della Sera 4 May 2017, p. 19.

Friedman, P. (ed.) (2007) Food, the History of Taste, London: Thames \& Hudson.

Gabaccia, D.R. (1998) We Are What We Eat: Ethnic Food and the Making of Americans. Cambridge, MA: Harvard University Press.

Gellner, E. (1983) Nations and Nationalism, Ithaca, NY: Cornell University Press.

Gold, C. (2007) Danish Cookbooks: Domesticity \& National Identity, 1616-1901, Seattle: University of Washington Press, Copenhagen Museum Tusculanum Press, University of Copenhagen.

Goodman, D., Dupuis, E.M. and Goodman M.K. (2012) Alternative Food Networks. Knowledge, Practice and Politics, London-New York: Routledge.

Gössling, S. and Hall, C. (2013) "Sustainable culinary systems: an introduction", in S. Gössling and C. Hall (eds), Sustainable Culinary Systems: Local Foods, Innovation, Tourism and Hospitality, London-New York: Routledge, 3-44.

Green, R. (2012) "Public histories of food", in J.M. Pilcher (ed.), The Oxford Handbook of Food History, Oxford: Oxford University Press, 81-96.

Guardiola y Ortiz, J. (1972), Gastronomía alicantina, Alicante: Agatángelo Solar Llorca.

Gutiérrez de Armas, J. (2017) "Gastronomía y construcción de la identidad nacional en Canarias, Un estudio de caso a partir de los recetarios del archivo Conde de Siete Fuentes (1880-1930)", Revista de Dialectologia y Tradiciones Populares LXXII(2): 533-54.

Gvion, L. (2011) “Cooking, food, and masculinity: Palestinian men in Israeli society”, Men and Masculinities 14(4): 408-29.

Han, K.K. (2011) “The 'kimchi war' in globalizing East Asia: consuming class, gender, health and national identity", in L. Kendall (ed.), Consuming Korean Tradition in Early and Late Modernity. Commodifications, Tourism and Performance, Honolulu: University of Hawaii Press, 149-66.

Hannerz, U. (2006) “Cosmopolitanism”, in J.Vincent and D. Nugent (eds), A Companion to the Anthropology of Politics, Oxford: Blackwell, 69-85.

Haraldsdóttir, L. and Gunnarsdóttir, G. (2014) “Pure, fresh and simple. 'Spicing up' the New Nordic Cuisine", in Joliffe L. (ed.) Spices and Tourism: Destinations, Attractions and Cuisines, London: Short Run Press, 169-81.

Harrington, R. and Ottenbacher, M. (2010) "Culinary tourism - a case study of the gastronomic capital", Journal of Culinary Science \& Technology 8(1): 14-32.

Hartog, F. (2015) Regimes of Historicity. Presentism and Experiences of Time, New York: Columbia University Press.

Heinzelmann U. (2014) Beyond Bratwurst: a history of food in Germany. London: Reaktion Books.

Hertz, E. (2017) "Bottom, genuine and spurious", in N. Adell, R. Bendix, C. Bortolotto and M. Tauschek (eds), Between Imagined Communities and Communities of Practice: Participation, Territory and the Making of Heritage, Göttingen: Göttingen University Press, 25-57.

Hobsbawm, E. (1983) "Introduction: inventing tradition", in E. Hobsbawm and T. Ranger (eds), The Invention of Tradition, Cambridge: Cambridge University Press, 1-14. 
Hobsbawm, E. (1990) Nations and Nationalism since 1780: Programme, Myth, Reality, Cambridge: Cambridge University Press.

Hobsbawm,E.and Ranger,T.(eds) (1983) The Invention of Tradition, Cambridge: Cambridge University Press.

Holak, S. (2014) "From Brighton Beach to blogs: exploring food-related nostalgia in the Russian diaspora”, Consumption Markets \& Culture 7(2): 185-207.

Holtzman J.D. (2006) "Food as memory", Annual Review of Anthropology 35: 361-78.

Ichijo, A. and Ranta, R. (2016) Food, National Identity and Nationalism: From Everyday to Global Politics, Basingstoke: Palgrave Macmillan.

Ingram, R. (2012) "Mapping and mocking: Spanish cuisine and Ramón Gómez de la Serna's 'El primer mapa gastronómico de España"”, Cincinnati Romance Review 33: 78-97.

Kaya, A. (2019) Populism and Heritage in Europe: Lost in Diversity and Unity, London: Routledge.

Kaya,A.and De Cesari,C.(eds) (2019), Populism and Memory in Europe,London: Routledge.

Kirshenblatt-Gimblett, B. (2004) "Foreword”, in L. Long (ed.), Culinary Tourism: Material Worlds, Lexington: University Press of Kentucky, xi-xiv.

Kuutma, K. (2012) "Between arbitration and engineering: concepts and contingencies in the shaping of heritage regimes", in R. Bendix, A. Eggert and A. Peselmann (eds), Heritage Regimes and the State, Göttingen: Universitätsverlag Göttingen, 21-38.

La Cecla, F. (1997) Il malinteso, Rome-Bari: Laterza.

La Cecla, F. (2016) Babel food. Contro il cibo kultura, Bologna: Il Mulino.

Laudan, R. (2013) Cuisine and Empire. Cooking in World History, Berkeley-Los AngelesWashington: University of California Press.

Leer, J. (2016) "What's cooking, man? Masculinity in European cooking shows after The Naked Chef”, Feminist Review 114: 72-90.

Lévi-Strauss, C. (1958) Anthropologie structurale, Paris: Plon.

Lloyd, P. (2015) Food and Identity in England, 1540-1640: Eating to Impress, LondonNew York: Bloomsbury Academic.

Lowenthal,D. (1994) “Identity, heritage, and history”, in J.R. Gillis (ed.), Commemorations: The Politics of National Identity, Princeton, NJ: Princeton University Press, 41-60.

Mannur, A. (2007) "Culinary nostalgia: authenticity, nationalism, and diaspora", Melus 32(4): 11-31.

Mason, L. (2004) "Inghilterra", in M. Montanari and F. Sabban (eds), Storia e geografia dell'alimentazione, vol. 2, Turin: Utet, 826-40.

McKinley, L. (2010) Yes to Polenta, No to Couscous!: Constructed Identities and Contested Boundaries between Local and Global in Northern Italy's Gastronomic Landscape, Henry M. Jackson School of International Studies Departmental Honors Thesis.

Mennell, S. (1985) All Manners of Food: Eating and Taste in England and France from the Middle Ages to the Present, Oxford: Basil Blackwell.

Metro-Roland, M.M. (2013) "Goulash nationalism: the culinary identity of a nation", Journal of Heritage Tourism 8:2-3, 172-81.

Mihăilescu,V. (2012) “Ulysse ou le balkanisme heureux”, Civilisations 60(2): 13-22.

Mintz, S. (1985) Sweetness and Power: The Place of Sugar in Modern History, New York: Viking.

Mintz, S. (2008) "Food and diaspora”, Food, Culture and Society 11(4): 509-23. 
Mintz, S. and Friedmann, H. (2004) "Colonialismo e prima mondializzazione", in M. Montanari and F. Sabban (eds), Storia e geografia dell'alimentazione, vol. 1, Turin: Utet, 421-38.

Möhring, M. (2012) Fremdes Essen: Die Geschichte der ausländischen Gastronomie in der Bundesrepublik Deutschland, Berlin: Walter de Gruyter.

Montanari, M. (2013) Italian Identity in the Kitchen, or Food and the Nation, New York: Columbia University Press.

Montanari, M. and Capatti, A. (2003) Italian Cuisine. A Cultural History, New York: Columbia University Press.

Narvselius, E. (2015) "Spicing up memories and serving nostalgias: thematic restaurants and transnational memories in east-central European borderland cities", Journal of Contemporary European Studies 23(3): 417-32.

Neuman, N. (2017) "An imagined culinary community: stories of morality and masculinity in 'Sweden - the new culinary nation"', Scandinavian Journal of Hospitality and Tourism 18: 149-62.

Neuman, N. and Fjellström, C. (2014) "Gendered and gendering practices of food and cooking: an inquiry into authorisation, legitimisation and androcentric dividends in three social fields", NORMA: International Journal for Masculinity Studies 9: 269-85.

Neuman, N. and Leer, J. (2018) "Nordic cuisine but national identities", Anthropology of Food 13. http://journals.openedition.org/aof/8723

Nora, P. (1989) "Between memory and history, Les Lieux de Mémoire", Representations 26: 7-24.

Ohnuki-Tierney, E. (1993) Rice as Self: Japanese Identities through Time, Princeton, NJ: Princeton University Press.

Omar, S., Karim, S., Bakar, A. and Omar, S.N. (2015) "Safeguarding Malaysian heritage food (MHF): the impact of Malaysian food culture and tourists' food culture involvement on intentional loyalty", Procedia-Social and Behavioral Sciences 172: 611-18.

Ory, P. (1992) "La gastronomie", in P. Nora (ed.), Les lieux de mémoire, vol. 3.2, Paris: Gallimard, 823-53.

Osterhammel J. (2014) The Transformation of the World: A Global History of the Nineteenth Century, Princeton, NJ: Princeton University Press.

Ott, C. (2011) Feinschmecker und Bücherfresser: Esskultur und literarische Einverleibung als Mythen der Moderne, Paderborn: Fink.

Parasecoli, F. (2017) Knowing Where It Comes From. Labelling Traditional Foods to Compete in Global Markets, Iowa City: University of Iowa Press.

Parkhurst Ferguson, P. (2004) Accounting for Taste: The Triumph of French Cuisine, Chicago: University of Chicago Press.

Parkhurst Ferguson, P. (2010) “Culinary nationalism”, Gastronomica 10(1):102-9.

Pérez Samper, M.d.1.Á (2012) "Lo scambio Colombiano e l'Euoropa”, in M. Montanari and F. Sabban (eds), Storia e geografia dell'alimentazione, vol. 1, Turin: Utet, 351-76.

Pilcher, J.M. (2012) "Cultural histories of food", in J.M. Pilcher (ed.), The Oxford Handbook of Food History, New York: Oxford University Press, 42-60.

Porciani, I. (2002) "Famiglia e nazione nel lungo Ottocento", in P. Ginsborg and I. Porciani (eds), Famiglia Stato Società civile special issue, Passato e presente 57, 11-39.

Porciani, I. (2008) "Weaving the nation together. Women's traditional needlework as a rhetorical tool in national and regional discourse", in Y.Yannitsiotis, D. Lambropolou, and C. Salvaterra (eds), Rhetorics of Work, Pisa: Plus, 27-44. 
Porciani, I. (2018) “Cibo come patrimonio. Un'introduzione”, Storicamente 14(1). doi: $10.12977 /$ stor691

Poulot, D. (1997) Musée, nation, patrimoine, 1789-1815, Paris: Gallimard.

Poulot, D. (2015) “Introduction”, in D. Poulot (ed.), Représentations et alimentation: arts et pratiques alimentaires (138 ${ }^{\mathrm{e}}$ Congrès national des sociétés historiques et scientifiques, Rennes, 2013), Paris: Éditions du CTHS, pp. 5-9.

Pujol, A. (2009) “Cosmopolitan taste”, Food, Culture \& Society 12(4): 437-55.

Ramli, A.M., Zahari, M., Ishahk, N. and Sharif, M. (2013) "Food heritage and nation food identity formation", Hospitality and Tourism: Synergizing Creativity and Innovation in Research 407: 162-8.

Ranta, R. (2015) "Food and nationalism: from foie gras to hummus", World Policy Journal. https://worldpolicy.org/2015/09/08/food-nationalism-from-foie-gras-to-hummus/

Raviv,Y. (2003) "Falafel: a national icon", Gastronomica 3(3): 20-5.

Régnier, F. (2005) "Le monde au bout des fourchettes: voyage dans l'exotisme culinaire". www.lemangeur-ocha.com/wp-content/uploads/2012/04/Regnier_ Exotisme_culinaire3.pdf

Renko, S. and Bucar, K. (2014) "Sensing nostalgia through traditional food: an insight from Croatia", British Food Journal 116(11): 1672-91.

Riera i Melis, A. (2004) "Spagna", in M. Montanari and F. Sabban (eds), Storia e geografia dell'alimentazione, vol. 2, Turin: Utet, 757-81.

Rockower, P. (2012) “Recipes for gastrodiplomacy”, Place Branding and Public Diplomacy, 8(3): 235-46.

Roden, C. (1974) Book of Middle Eastern Food, New York: Vintage Books.

Rogers, B. (2004) Beef and Liberty: Roast Beef, John Bull and the English Nation, New York: Chatto \& Windus.

Roux, J.V. (2017) La table: une affaire d'Etat, Paris: Les éditions du Cerf.

Rowley, A. (2006) Une histoire mondiale de la table. Stratégies de bouche, Paris: Jacob.

Rowley, A. (ed.) (1997) Les français à table. Atlas historique de la gastronomie française, Paris: Hachette.

Roy, P. (2002) "Reading communities and culinary communities: the gastropoetics of the South Asian diaspora", Positions: East Asia Cultures Critique 10(2): 471-502.

Saillard, D. (2010) "Nourritures et territoires en Europe. La gastronomie comme frontière culturelle", Eurolimes, Journal of the Institute for Euroregional Studies 9: 127-39.

Saillard, D. (2014) La Cuisine de l'Autre. Échanges et rivalités dans les relation s gastronomiques franco-anglaises $d u$ XVIIIe siècle à nos jours. https://hal.univ-lorraine.fr/hal-01484026

Scarpellini, E. (2016) "Il cibo come cultura italiana nel mondo: dall'emigrazione alla globalizzazione”, Memoria e Ricerca 24(2): 193-208.

Scholliers, P. (ed.) (2001) Food, Drink and Identity: Cooking, Eating and Drinking in Europe since the Middle Ages, New York: Berg, 3-22.

Scholliers, P. and Teughels, N. (2015) A Taste of Progress: Food at International and World Exhibitions in the Nineteenth and Twentieth Centuries, Farnham: Ashgate.

Selenis, V. (2010) "Lithuania", in I. Porciani and L. Raphael (eds), Atlas of European Historiography, Basingstoke: Palgrave Macmillan, 83-5.

Sengupta, J. (2010) "Nation on a platter: the culture and politics of food and cuisine in colonial Bengal”, Modern Asian Studies 44(1): 81-98.

Shields, J. (2014) "Le Front National: From Systematic Opposition to Systematic Disintegration?”, Modern E Contemporary France 22(4): 491-511. 
Sims, R. (2009) "Food, place and authenticity: local food and the sustainable tourism experience", Journal of Sustainable Tourism 17(3): 321-36.

Smith,A.K. (2009) "National cuisine and nationalist politics: V. F. Odoevskii and 'Doctor Puf', 1844-45", Kritika: Explorations in Russian and Eurasian History 10(2), 239-60.

Smith, A.K. (2012) "National cuisines", in J.M. Pilcher (ed.), The Oxford Handbook of Food History, New York: Oxford University Press, 444-60.

Smith, L. (2006) Uses of Heritage, London: Routledge.

Spang, R. (2000) The Invention of the Restaurant: Paris and Modern Gastronomic Culture, Cambridge, MA: Harvard University Press.

Storm, E. (2016) "The nationalisation of the domestic sphere", Nations and Nationalisms 23(1): 173-93.

Taguieff, P.A. (2015) La revanche du nationalisme: Néopopulistes et xénophobes à l'assaut de l'Europe, Paris: Presses universitaires de France.

Tellström, R., Gustafson, I. and Lindgren, H. (2008) "Constructed national food and meal archetypes at international exhibitions from Paris 1867 to Aichi 2005”, National Identities 10(3): 313-27.

Tholstrup Hermansen, M.E. (2012) "Creating terroir: an anthropological perspective on New Nordic Cuisine as an expression of Nordic identity", Anthropology of Food 7: 7249 .

Timothy, D. (2016) Heritage Cuisines: Traditions, Identities and Tourism, London-New York: Routledge.

Toaff, A. (2004) "Culture ebraiche nel mondo", in M. Montanari and F. Sabban (eds), Storia e geografia dell'alimentazione, vol. 2, Turin: Utet, 272-85.

Tornatore, J.L. (2012) “Anthropology's payback: the gastronomic meal of the French, the ethnographic elements of a heritage distinction", in R. Bendix, A. Eggert and A. Peselmann (eds), Heritage Regimes and the State, Göttingen: Universitätsverlag Göttingen, 341-65.

Ubertazzi, B. (2015) "The territorial condition for the inscription of elements on the UNESCO lists of Intangible Cultural Heritage", in N. Adell, R. Bendix, C. Bortolotto and M. Tauschek (eds), Between Imagined Communities and Communities of Practice Participation, Territory and the Making of Heritage, Universitätsverlag Göttingen: Göttingen, 111-22.

Vester, K. (2015) A Taste of Power: Food and American Identities, Berkeley-Los AngelesWashington: University of California Press.

Watts, S. (2012) "Food and the Annales School", in J.M. Pilcher (ed.), The Oxford Handbook of Food History, New York: Oxford University Press, 3-17.

Welz, G. (2013) “Contested origins”, Food, Culture \& Society 16(2): 265-79.

Whitehead, C., Bozoğlu G. and Daugbjerg, M. (2019) "Remapping European heritage and memory: positions, inspirations, approaches", in C. Whitehead, S. Eckersley, M. Daugbjerg and G. Bozoğlu (eds), Dimensions of Heritage and Memory: Multiple Europes and the Politics of Crisis, London: Routledge.

Wincott, A. (2015) "Heritage in danger or mission accomplished?" Food, Culture \& Society 18(4): 569-88. 
Part I

Heritagization and political uses of food 
$\because$ Taylor \& Francis Taylor \& Francis Group

http://taylorandfrancis.com 


\title{
Heritage and food history
}

\author{
A critical assessment
}

\author{
Laura Di Fiore
}

\section{Heritagization of food: places and histories}

In recent years the copious literature generated by food studies has responded to the promptings of the "heritage turn" and channelled attention into the topic of food as heritage. Food as an identity heritage is not an ontological entity but the product of appropriation dynamics (Bienassis 2011), triggered by certain groups, communities and societies. The process of heritagization - sometimes the French term patrimonialization is used (Grasseni 2013) - thus rests on a cultural construction of food that tends to invest it with an identity paradigm and sense of belonging. The identity may already exist, at least in part, but in some cases is "invented" or at any rate transformed in the course of patrimonialization. But food cultures are, in turn, constantly being reproduced and reinvented (Ceccarelli, Grandi and Magagnoli 2013; Grasseni 2007) through the acquisition of new symbolic value. Hence a historical analysis becomes essential to multidisciplinary food studies. Historicizing the processes that produce cultural paradigms enables them to be deconstructed. Attention to the historical aspect is part and parcel of constructing cuisines, culinary paradigms and feeding styles as the heritage of a given community and a given local area.

The production of a food heritage rests on a twofold anchor: one part historical, the other geographic (Geyzen 2014). A sizable part of the recent literature has analysed cuisines and eating patterns in terms of significant place-based identity markers and indicators of belonging; the scale has varied, from local to regional, national and even transnational. To connect food and place is to mix physical with sociocultural features, as is evident in the concept of terroir. Going by the definition given by experts at the French Institut national de l'origine et de la qualité (INAO) - the first national institute charged with protecting it - terroir consists in "a specific geographical space where a human community has historically produced a collective knowledge, based on the intertwining of a physical environment with human factors" (Ferrières 2013, 25; Parker 2015). The uniqueness of foods from specific places is acknowledged to lie in their being the product of a complex geographical-historical milieu composed of factors both natural (geological properties of the soil, micro-climates) and 
human (long-standing knowledge and skills handed down from generation to generation). But as Fabio Parasecoli has pointed out, "connections between food and place are not "natural"” (Parasecoli 2017, 2). For them to be perceived as such, first, the foods need to be claimed as exclusive in origin to a particular place and local culinary tradition, and second, the claim needs to be upheld by an official institute. The seal on the patrimonialization of food is what Parasecoli calls "place-based labels" which, differing no doubt in degree and purpose, focus "specifically on the geographical origin of a product" (Parasecoli 2017, 7).

From this concept of a terroir underlying the certification of origin, it thus emerges that the geographical/physical side and the historical/cultural side are intimately connected. Even when the labels are directly concerned with a market and economic factors, the scope of historical and sociocultural features is evident. One example here might be the geographical descriptors issued by the European Union as part of a programme started in 1992 that has enabled food and foodstuffs to be registered under a brand name certifying the geographical provenance (in terms of ingredients and/or production processes). ${ }^{1}$ The main aim of EU geographical descriptions is to provide a guarantee for both consumers and producers: they prevent a registered name from being used inappropriately. However, the cultural aspect is by no means lacking from such labelling. The regulation stipulates that the certificate of origin and the geographical description are designed to protect "the quality and diversity of the Union's agricultural, fisheries and aquaculture production" as making "a major contribution to its living cultural and gastronomic heritage". As we see from the controversies over geographical certification of Italian parmigiano reggiano or Greek feta or the foie gras issue, the question is not just economic: identity plays a by no means secondary part (de Soucey 2010, 433). Again, although the nomination forms for EU brand certification require nothing but a specific description of the product giving details of the physical characteristics and production phases ${ }^{2}$ it is common for the section devoted to the link with a geographical area to allow mention of traditional practices dating back in time and handed down across the generations. ${ }^{3}$

However, when it comes to other kinds of labels, such as those attesting UNESCO recognition of mankind's immaterial cultural heritage, the historical-cultural-identity aspect of the food tradition jumps into first place. The United Nations agency pursues another purpose from Europe's certification of geographical origin, for by including certain dishes, culinary traditions and cuisines in its Representative List of Intangible Cultural Heritage (ICH) it aims to safeguard and acknowledge "cultural diversity and human creativity", seen as a common good of mankind. ${ }^{4}$ What, then, does "Intangible Cultural Heritage" consist of? The concept was created in 2003 by the Convention for the Safeguarding of Intangible Cultural Heritage: it tried to redress the Western bias in the 1972 World Heritage Convention which was dedicated to mankind's natural and cultural heritage. In the 2003 definition Intangible Cultural Heritage refers to: 
the practices, representations, expressions, knowledge, skills - as well as the instruments, objects, artefacts and cultural spaces associated therewith that communities, groups and, in some cases, individuals recognize as part of their cultural heritage. This intangible cultural heritage, transmitted from generation to generation, is constantly recreated by communities and groups in response to their environment, their interaction with nature and their history, and provides them with a sense of identity and continuity.

(Blake 2006; Lixinski 2014)

From 2010, when certain cuisines and eating patterns were inscribed, food culture has loomed increasingly large in the practices and forms of know-how listed as $\mathrm{ICH}^{5}$

The nomination forms for inscription on the list reveal the primacy of the cultural side to heritage. The description of the item (or "element") should emphasize "the characteristics of the bearers and practitioners of the element" and "the current modes of transmission of the knowledge and skills related to the element" and provide "an explanation of its social and cultural functions and meanings today, within and for its community". ${ }^{6}$ Unlike the European Union's Geographical Indications, these forms specifically recommend that "overly technical descriptions should be avoided". Hence the nomination files of the items on the list contain many more references to the importance of "a customary social practice" and its symbolic significance, such as "togetherness, consideration of others, sharing the pleasure of taste, the balance between human beings and the products of nature", than to the strict characteristics of the food in question. ${ }^{7}$ This slant to the submission of cuisines or dishes to the UNESCO committee can also be detected from the pictures and videos that form an integral part of nomination files, which focus more on the associated sharing and consuming patterns than on the food itself.

Lest we fall into oversimplification, note that priority to cultural goals does not mean that UNESCO food labelling lacks all economic implications. True, one recent study on the use of UNESCO recognition for marketing has shown that this is still a limited occurrence (de Miguel Molina, de Miguel Molina, Campos and Oña del Val Segarra 2016). We no doubt need to await further research assessing the economic impact of such a recent phenomenon (Pfeilstetter 2015). One field where the effect of UNESCO labelling does tend to count - from cuisines figuring on the $\mathrm{ICH}$ list to the election of Creative Cities of Gastronomy (Pearson and Pearson 2016) - is the world of tourism to which food studies have been devoting special attention in view of the growing trend for gastronomic tourism (Bessière 2013; Long 2013; Timothy 2016). But once again with food-based tourism, the cultural, historical and identity dimension outweighs the more material side that we usually associate with tourism. The image of heritage cuisines and "traditional" or "authentic" food vexed definitions, as we shall see - forms an essential feature in the branding of 
tourist venues whose appeal is boosted and sometimes entirely generated by the presence of local gastronomy. The tourist is promised a more authentic experience of the place - a factor of identity to cherish in the memory and hence, more generally, denoting the local cultural heritage (Björk and KauppinenRäisänen 2017; Thomé-Ortiz 2018).

For this reason, the process of food heritagization via labelling linked to inclusion in the UNESCO ICH strikes me as a good lens through which to examine the dynamics of culture and identity-building concerning food heritage. I begin by analysing the place-based identity paradigms justified by UNESCO procedure and how they are deployed on various spatial levels that subtly overlap and intertwine. Secondly, I take a close look at a basic building block of that place-based identity construct, namely recourse to past history. In doing this I spotlight some of the critical features of institutional food heritagization.

\section{The geographical complexity of international labelling}

Given the link between food and place - a distinctive feature of food heritage - UNESCO heritagization of the immaterial accords pride of position to localities and, more precisely, the communities that inhabit them. These are the primary subjects under which culinary traditions, know-how and gastronomic practice can be listed.

The nomination procedure lays particular stress on "participation of the communities, groups and, where appropriate, individuals, in the elaboration of nomination files". ${ }^{8}$ The community's free, prior, informed consent is an obligatory part of the inscription documentation. The UNESCO guidelines to preparing the nomination form spell it out: "No topic has received greater attention from the Committee [than the communities' role]". ${ }^{9}$ But who actually represents or embodies these communities? The central role goes to local institutions like town halls, subnational administrative bodies or mayors' associations. Likewise, local associations of chefs and cooks, cultural organizations, and various kinds of labour associations stand as examples of the community with roots in the localities. Localities and communities are the prime entities applying to UNESCO for candidacy of a food brand or cuisine which is important to safeguard for the economic fabric and cultural identity of the area. Take the "Mediterranean Diet", for example (Scepi and Petrillo 2015; Stano 2015; Turmo, Verdù and Navarrete 2008). The nomination file specifies that "the communities that recognize it as part of their common intangible cultural heritage [are] Agros (Cyprus), Brač and Hvar (Croatia), Soria (Spain), Koroni/Coroni (Greece), Cilento (Italy), Chefchaouen (Morocco), [and] Tavira (Portugal)" ${ }^{10}$

In applications to the UNESCO committee the peculiar virtues of traditional food or "foodways" are described as in danger of being eclipsed by the advance 
of the global market with its economic mechanisms and its standardization of foodstuffs and consumer patterns. Thus, in presenting the nominations of the French Gastronomic Meal (Csergo 2016; Tornatore 2012) and the Japanese Washoku for inclusion in the UNESCO list, the respective professional and workers' associations expressed concern at the risk of their culinary tradition and specific know-how disappearing (Ichijo and Ranta 2015, 147-57). Similarly, in the more recent case of UNESCO recognition going to the "Art of the Neapolitan Pizzaiuolo" - inscribed in December 2017 - the emphasis on know-how rather than the product in itself reflected the urgent need to counter the claims of the main competitor for pizza paternity, the United States. The United States achieves the highest consumption rate and earns the greatest profits through its major pizza chains. In this case too the 3,000 pizzaiuoli practising the art and the category associations (including the Associazione Pizzaiuoli Napoletani and the Associazione Verace Pizza Napoletana) sought UNESCO protection for the art of pizza preparation, which they described as "threatened by globalization, distorted and often counterfeited all over the world". ${ }^{11}$

Yet this local/global rivalry proves to be a rhetorical simplification compared with the far more complex intersecting levels on which identity dynamics are played out. For one thing, the local cuisines claiming protection against the thrust of globalization aspire to achieving (and bolstering) a distinctly global appeal. Once the heritage nature of a cuisine is made official, the trend is to tailor its singular features to the expectations of a global consumer elite. In the end arise what Claire Sammells calls "haute traditional cuisines" (Sammells 2014, 144).A typical instance of this occurred with traditional Mexican cooking, inscribed in 2010. The nomination file presented that cuisine as native, traditional and feminine, stressing its deep roots with no reference to its cosmopolitan overtones. With nomination successfully in the bag, promotion of Mexican cuisine became the exclusive province of male chefs, a transnational class of professionals trained in the French tradition. The accent was also placed on global ingredients and techniques, tailored to the taste buds of cosmopolitan consumers (Sammells 2014, 147-50).

This global shift by local culinary paradigms is not just a top-down process. Local players - entrepreneurs, local institutions and cultural and trade associations - build a bottom-up picture of the authenticity of their food, seeking to appeal to a global public and to global institutions. Thus, promotion of local products and traditions leads to a kind of "commodification of the locality" via deliberate marketing strategies (Grasseni 2013) which transform "local" into "typical" (Grasseni 2013;Vitrolles 2011); they reduce their food culture to essential points, sometimes glossing over what may be actual cosmopolitan features (as with French cuisine), and then adapt them artificially to international tastes and requirements. This trend by some long-standing nominations is not found in the case of the community behind the "Art of the Neapolitan Pizzaiuolo". It may partly be due to the latest UNESCO directives, but this last community 


\section{Food in UNESCO intangible cultural heritage}

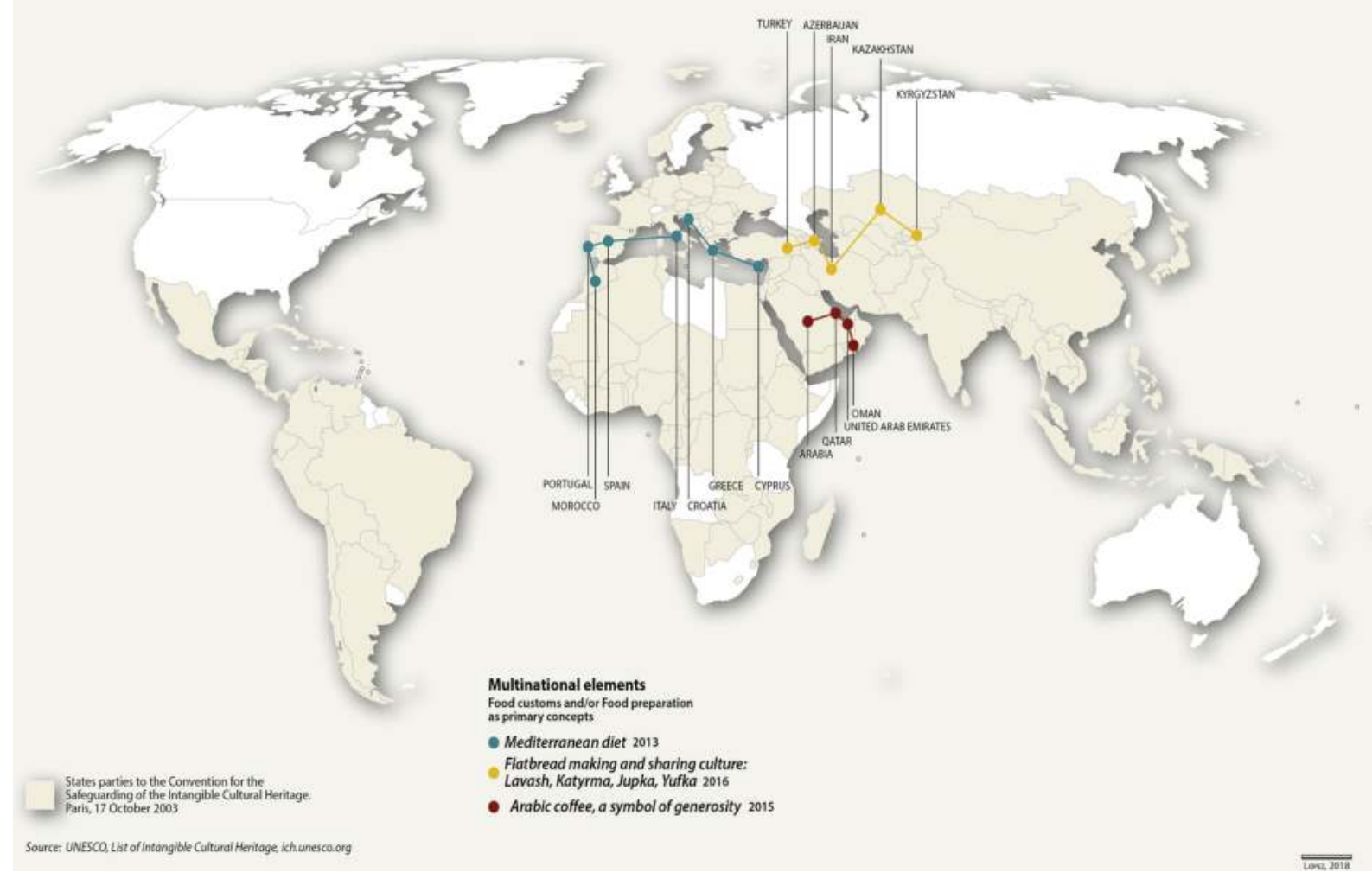

Figure 2.I Food in UNESCO Intangible Cultural Heritage 
gets identified not just with the associations mentioned, but with the "whole population" of the Naples metropolitan area and even with the whole community "all around the world" that upholds the symbolic and cultural values enshrined in properly prepared pizza. ${ }^{12}$

Secondly, simple opposition between local and global so easily obscures the real dynamics at work in the UNESCO-run process of heritagization, where it is nation states rather than local communities that vie with one another. This fact depends firstly on the UNESCO labelling procedure itself, which forbids communities to apply for nomination directly. State institutions filter the local proposals and end by being the only entities directly interacting with the international body. Again, UNESCO's preference for broadly shared traditions paradoxically tends to jeopardize the cultural variety and diversity it is meant to protect. Thus, certain local food patterns often end up representing a whole nation, overshadowing the local and regional matrix of some cuisines. This was clear with the Mexican nomination. A native cuisine from a small region - the so-called Michoacán paradigm - was turned into a national cultural model (Domenici 2018). Again, with the French Gastronomic Meal, the "community concerned" became identified with "the entire French nation"; likewise with more recent inscriptions, such as kimchi preparation or Belgium's beer culture: the food heritage candidate tends to stress national points in common although the communities and social groups are local. ${ }^{13}$

In this way the community that is presumed to enjoy the UNESCO nomination loses contact with the locality it represents, which is crushed by absorption into the national orbit. Local and regional culinary traditions get presented and perceived as representing the nation (de Soucey 2010), and it is on that scale that the economic effects of nomination are measured. This goes for the food industry as for the culture industry, for example in the case of tourism. Such enforced inclusion in a predominantly nationalistic model obscures the many cultural, class or gender differences involved in feeding rituals and habits, not to mention division and conflict within the local community itself. Aware of this risk, the UNESCO committee and its evaluation bodies recently stressed "the persisting problem whereby the communities concerned by the element or activity in question are not well-defined". ${ }^{14}$ They particularly point out that the "communities are not monolithic and homogeneous, but are stratified by age, gender and other factors", and encourage candidates to describe the "diversity of actors and their roles in relation to specific intangible cultural heritage and the social dynamics that it generates". ${ }^{15}$ These points refer to forms of identity different from place-based ones: very much the kind of sociocultural identity that food studies, and food history especially, have gone into so eloquently. In relation to the more or less recent past, for example, historians have investigated the symbolic and identity meanings of food for certain social classes, involving reconstruction of rituals and venues (Bouchet 2016; Erby 2017), and more generally the eating habits of the middle and working classes (Finn 2017; Lloyd 2015; Ray 2015; Scholliers 2012), as well as specific profiles 
linked to working in the food system - from chefs to food industry workers (Olmedo 2015; Van den Eeckhout 2013); they have probed feeding patterns in specific collective experiences or extreme situations - school, hospital, prison, war (Collingham 2013; Hawkins and Tanner 2016; Maes, Vanhouche, Scholliers and Beyens 2017) - often looking at objects of material culture connected with eating. The recent literature has been concerned with food heritages with religious connotations (Avieli 2009; Freidenreich 2014), as well as gender dynamics filtered through the lens of food consumption and preparation, especially focusing on the role of women in what tends to be conceived as a feminine domain (Cairns and Johnston 2015; Jones-Gailani 2017; Segalla 2016; Szabo and Koch 2017) - at least in the home - as well as on generational identities displayed through tastes and feeding habits (Anderson 2017; Tichit 2015).

Contrasting with the monolithic communities outlined by UNESCO nominations that so differ from the multiply nuanced situations analysed by the recent literature, the candidates presenting the "Art of the Neapolitan Pizzaiuolo" are far more strictly linked to the locality of urban Naples and more widely stratified socially, including unusual groups that make this a heritage of great interest. The art of the pizza is a distinctly "social" and "family heritage". It entails "functions of social aggregation and inter-generational exchange", using a ritual loaded with Neapolitan dialect and slang. ${ }^{16}$ Indeed, it ranks as a key feature in the socio-economic fabric of the city, spelling emancipation from poverty. Many a youthful victim of typical southern Italian social marginalization has found learning the pizzainolo trade a refuge from straitened circumstances and sometimes crime. For the consumer too the pizza is cheap, accessible to the least well-off. It is also a symbol of social solidarity through the custom of "standing a pizza" (una pizza sospesa), a courtesy free meal ticket for someone who probably can't afford it. ${ }^{17}$

The UNESCO nomination tendency to dress up communities in very similar colours, lifted out of context and given a national frame, has also resulted in a spate of disputes among countries. When nation states get to dominate the labelling procedure, they take it as an opportunity to wield forms of soft power on the international scene. Nation states tend to exploit official certification of an exclusive product or cuisine and use the kudos of recognition to promote their own food image as a strategy of "national branding".

Political exploitation of food is nothing new, but it has risen to new proportions in recent years. It is called gastrodiplomacy (Ichijo and Ranta 2015, 108-12), and entails producing and using food brands as a weapon of soft power in the international arena. This has increased considerably following the impact of the global food market, where the alleged peculiarities of national culinary identity are being powerfully manipulated. To gauge the relation between food and globalization, Michaela de Soucey has invented a new concept: gastronationalism, which "signals the use of food production, distribution, and consumption to demarcate and sustain the emotive power of national attachment, as well as the use of nationalist sentiments, to produce and market food" (de Soucey 2010 
433). As a vector of "collective national identity" (de Soucey 2010, 434), labelling procedure becomes an international battlefield where states flaunt their own "cultural nationalism in response to globalisation"; the paradoxical upshot is that institutions like UNESCO, "meant to limit the scope of nationalism", "end up enhancing the nationalist case" (Ichijo and Ranta 2015, 157). There is a potency behind such "gastrolinguistics" (Cavanaugh 2016; Lakoff 2006), and once a food or cuisine is defined as "national", thereafter it will be hailed and perceived as such. Successful nomination of a cuisine justifies a country appropriating it and delegitimizes all claim to it by others. Food then turns into a "contested medium of cultural politics that demarcates national boundaries and identities" (de Soucey 2010, 433). Claims to food paternity, like so many frontier lines, prove a crucial way of defining national belonging. In the end this traces an insidious line of inclusion/exclusion.

Food labels have fuelled many a dispute. One interesting example is the Turkish-Armenian quarrel over keşkek, which made it onto the UNESCO list as a Turkish heritage in 2011; another is the 2014 recognition of lavash as an Armenian product. This caused a broad rumpus throughout the region, with Azerbaijan at the fore (Aykan 2016). We have seen "hummus wars" in the Middle East and "kimchi wars" between China, Japan and Korea, raising identity issues and national interests, and in some cases even questions of national security. Mindful of the impact of language and the risks it may entail, the ICH section of UNESCO has issued a warning in the Memoire for applicants not to use "inappropriate vocabulary" or potentially divisive expressions like "pure", "true", "unique" or "original", and more generally to avoid turns of phrase "not conducive to dialogue or that had political connotations to be avoided. [...] [L]anguage that risks inciting tensions or awakening grievances, whether between communities or between States, should be rigorously avoided". ${ }^{18}$

Where foods or culinary traditions cross national borders, the Convention for the Safeguarding of Intangible Cultural Heritage actually contemplates attribution to more than one country and multi-country candidature is possible; items already on the list can be extended to a number of states. Nominations for such "shared heritages" are warmly encouraged. The "Mediterranean Diet" is an example of this procedure, "Arabic coffee" another, though the fact is that there are few enough such transnational food cultures on the UNESCO list. ${ }^{19}$ It does seem that change is afoot, however. December 2016 saw the inclusion of "Flatbread making and sharing culture: Lavash, Katyrma, Jupka, Yufka"20 on the ICH list at the joint request of Azerbaijan, Iran, Kazakhstan, Kyrgyzstan and Turkey, the very countries of western Asia that had contested the nomination for lavash bread going to Armenia. Again, Algeria's candidacy of couscous turned into a broader dossier centring on Maghreb: that involved the whole geographical area, including Morocco and Tunisia, where the Berber dish is indeed widespread.

For the time being, though, transnational candidatures are few and far between, however much UNESCO may encourage them. It goes to show how 
national identity and interest continue to play a key role in the international game of labels. But this is to ignore the sharing of recipes and customs by adjacent areas, and the exchange and circulation of know-how among different and even far-flung regions, through which all cuisines become hybrid.

\section{"Traditions" with no history: using the past in food heritagization}

Contacts in the spatial sense are thus ignored or considerably scaled down in labelling practice, and the emphasis is placed on alleged continuity in time. A unique eating style or custom gets confined to a limited area and its roots are traced back into the past; it is styled "traditional" or "authentic", and the fact of being handed down over a number of generations purports to guarantee its vertical descent in time. This rules out any horizontal exchanges, contacts or influences from other places and communities, whether present or past. But what kind of past history is so repeatedly being claimed in heritagization processes as legitimizing cuisines and culinary practices?

"Authentic", "original" and "traditional" are the common terms cited to support the paternity claim for cooking styles. The "olde worlde" adjectives suggest the transmission of know-how and recipes from generation to generation, a kind of sedimentation over the centuries, knowledge belonging to one community that not only possesses the secret but lays claim to some symbolic or identity title. Harking back to the past is definitely a vital feature in building up a food heritage and often, by a mechanism of complete assimilation, "the past is turned into heritage" (Parasecoli 2017,3). One recently produced conceptual guide to food as heritage gives the main ingredients as "tradition", "authenticity" and "memory" (Geyzen 2014).

But such a conceptual framework has problems. For one thing, the term "authentic" and its synonyms belong, as we saw, to the "inappropriate vocabulary" for UNESCO nomination files, and not just because of the nationalistic connotations making such claims of exclusiveness a potential source of friction. The idea of authenticity is also against the basic principles of $\mathrm{ICH}$. As its subsidiary body stated in 2011 and 2012, UNESCO does not intend to "fix intangible cultural heritage in some frozen, idealized form", since "it is not concerned with the question of how 'original' or 'authentic' an element is or what its 'ideal' form should be, rather what matters is how an element figures in the lives of its practitioners today" (Bortolotto 2003, 75). The principle is therefore safeguarding without freezing. ${ }^{21}$ Yet research by Chiara Bortolotto has shown that the term "authenticity" continues to figure frequently in nomination files by virtue of its connection to the "idea of antiquity ("thousand-yearold practices') or to territorially rooted (often rural) communities" (Bortolotto 2003 , 76). A past conjured up by the idea of authenticity as a sine qua non does indeed become immobile, crystallized in an original form to be handed down unchanged over the centuries via teaching and recipe books allegedly preserving 
local memory and tradition. Food studies has explored the link between food and memory (Holtzman 2006; Sutton 2006). It evokes an emotional side to the food experience, encompassing “edible memories" (Jordan 2015) and nostalgia for "granny's cooking". In such a framework recipe books - on which the literature has again recently focused - become the custodians, no less, of culinary memory. But, on one hand, they tend to reproduce a crystallized version of know-how and practice divorced from the change that historical development implies; on the other hand, they share in the general mechanism of selection whereby memory - individual or collective, of a cultural construct or a personal experience - filters the past by omission and "oversight" and inevitably leaves a partial version (Abarca 2004; Sutton 2006). The selection mechanism, note, is not so different from outright "invention of tradition" which, in itself and historically viewed, may be dismissed as insignificant except as a social and cultural construct.

Frozen, immobile, shaped by individual and collective memory - such is the past as evoked by food heritagization, a past that paradoxically turns out to be quite ahistorical, since in this way one ignores its actual dynamics, the central role in which is played by cultural exchange, the diffusion of skills and the circulation of eating patterns across Europe and around the globe. These are phenomena that food history has increasingly unearthed in recent years as a specific feature in the formation of the world's food cultures (Claflin and Scholliers 2013; Montanari 2002; Pilcher 2008). It is these spatial connections that get especially obscured, for example in UNESCO candidatures, where evocation of the past is always vague and partial. If we take the latest culinary nomination on the list, we will see that the "Art of the Neapolitan Pizzaiuolo" follows the prevailing trend. It refers to the need for preserving its "authenticity" - though that is just what the UNESCO committee stigmatized in its Decisions, since that way one undermines the assumption of a "living heritage, which is by definition constantly recreated by the communities concerned". ${ }^{22}$ The authenticity of the Neapolitan heritage allegedly dates from 1889, when the Neapolitan pizzeria Brandi produced a pizza in homage to Queen Margherita: the colours of tomato, mozzarella cheese and basil supposedly alluded to the Italian flag. Recent studies have queried the historical basis of that well-known story (Helstoski 2008; Nowak 2014), reference to which is a pure case of exploitation of the past. Note how the fact of Neapolitan identity being reluctant to be absorbed into a broader Italian identity has not stopped it appropriating the national symbol of the pizza which so denotes it abroad.

More generally, the historical references that loom so large in the paternity suit for the pizza actually boil down to two: that fleeting reference to a late 19th-century episode, and a generic claim to a 16th-century origin. Citing the multicultural nature of the city of Naples does not warrant the same feature being applied to the art of the pizza and its historical development.

The heritagization of food via food labelling procedures seems to be heading quite a different way from the flourishing spate of food studies within which 
food history has appeared in the past few years. Some form of dialogue with scholars would be no bad thing, to try and put an end to the limitations currently cramping the institutions' view of food as a heritage.

Food heritages figure as monolithic entities rigidly linked to geographical location. The communities in question get levelled into models that ignore fine differences and internal division, and the locations get caught up in national frameworks that make no allowance for connection, circulation or exchange with other places. The origins and permutations of such phenomena are ignored, and the phenomena themselves are currently denied by a lingering hostility to transnational nominations. The past serves to legitimize claims to and appropriation of heritage, but reduces, in the process, to a completely ahistorical abstraction. It is chopped up by the mechanisms of memory, selected for the purposes of transmitting knowledge, and cobbled together according to local marketing needs to fashion "commodity-heritages" (Grasseni 2005, 80). This is to obscure the long history of connection and transferral, chapters like the medieval exchange (Montanari 1988, 1993), the "Columbian exchange" (Crosby 1972) and the circulation of food cultures throughout empires (Laudan 2013; Leong-Salobir 2011). These are the real dynamics of the global culinary heritage, and they lie behind the hybrid, entangled nature of all culinary identities.

\section{Notes}

1 Regulation (EU) No. 1151/2012 of the European Parliament and of the council of 21 November 2012 on quality schemes for agricultural products and foodstuffs.

2 European Union, Agriculture and Rural Development, Door. Retrieved from http:// ec.europa.eu/agriculture/quality/door/list.html?locale=en accessed November 2018.

3 Recent examples are "Marche" oil, registered on 20 April 2017, and the "London cure smoked salmon", registered on 12 April 2017. Retrieved from http://ec.europa. eu/agriculture/quality/door/list.html?locale=en accessed November 2018.

4 UNESCO, Convention for the Safeguarding of Intangible Cultural Heritage, art. 2. Retrieved from https://ich.UNESCO.org/en/convention accessed November 2018.

5 https://ich.UNESCO.org/en/lists accessed November 2018.

6 UNESCO, Aide-mémoire for completing a nomination to the Representative List of the Intangible Cultural Heritage of Humanity for 2016 and later nominations. Retrieved from www.UNESCO.org/culture/ich/en/forms accessed November 2018.

7 UNESCO, Nomination file no. 00437 for inscription in 2010 on the Representative List of the Intangible Cultural Heritage of Humanity. Intergovernmental Committee for the Safeguarding of the Intangible Cultural Heritage. Retrieved from www. UNESCO.org/culture/ich/en/RL/gastronomic-meal-of-the-french-00437 accessed November 2018.

8 UNESCO, Forms to be used for nominations, proposals, assistance requests, accreditation requests and periodic reporting. Retrieved from www.UNESCO.org/culture/ich/en/ forms accessed November 2018.

9 UNESCO, Aide-mémoire for completing a nomination, p. 15. 
10 UNESCO, Nomination file no. 00884 for inscription in 2010 on the Representative List of the Intangible Cultural Heritage of Humanity. Intergovernmental Committee for the Safeguarding of the Intangible Cultural Heritage. Retrieved from www.UNESCO.org/culture/ich/en/RL/mediterranean-diet-00884 accessed November 2018.

11 UNESCO, Nomination file no. 00722 for inscription in 2017 on the Representative List of the Intangible Cultural Heritage of Humanity. Intergovernmental Committee for the Safeguarding of the Intangible Cultural Heritage. Retrieved from https://ich. UNESCO.org/en/RL/art-of-neapolitan-pizzaiuolo-00722 accessed November 2018.

12 UNESCO, Nomination file no. 00722.

13 UNESCO, Nomination file no. 00437.

14 UNESCO, Aide-mémoire for completing a nomination, p. 16.

15 Ibidem.

16 UNESCO, Nomination file no. 00722.

17 Ibidem.

18 UNESCO, Aide-mémoire for completing a nomination, p. 10.

19 Previously the Turkish coffee had been included in the list in 2013. Retrieved from https://ich.UNESCO.org/en/RL/turkish-coffee-culture-and-tradition-00645 accessed November 2018.

20 Retrieved from https://ich.UNESCO.org/en/RL/flatbread-making-and-sharingculture-lavash-katyrma-jupka-yufka-01181 accessed November 2018.

21 UNESCO, Safeguarding without freezing. Retrieved from www.UNESCO.org/ culture/ich/en/safeguarding-00012 accessed November 2018.

22 UNESCO, Intergovernmental Committee for the Safeguarding of the Intangible Cultural Heritage, Decisions, Twelfth session, Jeju Island, Republic of Korea, 4-9 December 2017, p. 63.

\section{References}

Abarca, M.E. (2004) “Authentic or not, it's original”, Food \& Foodways 1: 1-25.

Anderson, D. (2017) "Consuming memories: food and childhood in postbellum plantation memoirs and reminiscences", Food Culture and Society 3: 443-61.

Avieli, N. (2009) “"At Christmas we don't like pork, just like the MacCabees'. Festive food and religious identity at the Protestant Christmas picnic in Hoi An", Journal of Material Culture 2: 219-41.

Aykan, A. (2016) "The politics of intangible heritage and food fights in Western Asia”, International Journal of Heritage Studies 22(10): 799-810.

Bessière, J. (2013) “'Heritagisation', a challenge for tourism promotion and regional development: an example of food heritage", Journal of Heritage Tourism 4: 275-91.

Bienassis, L. (2011) "Les chemins du patrimoine: de Notre-Dame au camembert", in A. Campanini, P. Scholliers and J.-P.Williot (eds), Manger en Europe. Patrimoines, échanges, identités, Brussels: Peter Lang, 45-91.

Björk, P. and Kauppinen-Räisänen, H. (2017) “A destination's gastronomy as a means for holiday well-being”, British Food Journal 7: 1578-91.

Blake, J. (2006) Commentary on the 2003 UNESCO Convention on the Safeguarding of the Intangible Cultural Heritage. Leicester: Institute of Art and Law. 
Bortolotto, C. (2003) "Authenticity: a non-criterion for inscription on the lists of UNESCO's Intangible Cultural Heritage Convention, IRCI Meeting on ICH, Evaluating the Inscription Criteria for the Two Lists of UNESCO's Intangible Cultural Heritage Convention", in Final Report, The 10th Anniversary of the 2003 Convention, 10-11 January 2013, Tokyo, Japan.

Bouchet, T. (2016) La gamelle et l'outil: manger au travail en France et en Europe de la fin du XVIIIe siècle à nos jours, Nancy: Arble bleu.

Cairns, K. and Johnston, J. (2015) Food and Femininity, London: Bloomsbury.

Cavanaugh,J.R. (2016) "Talk as work: economic sociability in northern Italian heritage food production", Language \& Communication 48: 41-52.

Ceccarelli, G., Grandi, A. and Magagnoli, S. (eds) (2013) Typicality in History: Tradition, Innovation and Terroir/La typicité dans l'histoire: tradition, innovation et terroir, Brussels: Peter Lang.

Claflin, K. and Scholliers, P. (eds) (2013) Writing Food History: A Global Perspective, London: Berg.

Collingham, E.M. (2013) The Taste of War: World War II and the Battle for Food, London: Penguin Books.

Crosby, A. (1972) The Columbian Exchange: Biological and Cultural Consequences of 1492, Westport, CT: Greenwood Publishing Group.

Csergo, J. (2016) La gastronomie est-elle une marchandise culturelle comme une autre? La gastronomie française à l'UNESCO: histoire et enjeux, Paris: MenuFretin.

de Miguel Molina, M., de Miguel Molina, B., Campos, V.S. and Oña del Val Segarra, M. (2016) "Intangible heritage and gastronomy: the impact of UNESCO gastronomy elements", Journal of Culinary Science \& Technology 14(4): 293-310.

de Soucey, M. (2010) "Gastronationalism. Food traditions and authenticity politics in the European Union", American Sociological Review 75(3): 432-55.

Di Fiore, L. (2018) “Bibliography 'Food as Heritage'”, Storicamente 14(2). doi: 10.12977/ stor692

Domenici, D. (2018) "Gastropolitiche messicane. Il processo di riconoscimento UNESCO e l'idea di nazione”, Storicamente 14(2). doi: 10.12977/stor721

Erby, K. (2017) "Dining on dissolution: restaurants, the middle class, and the creation of the family dinner in mid-nineteenth-century America", Food Culture and Society 4: 671-84.

Ferrières, M. (2013) Terroir: jalons pour l'histoire d'un mot, in G. Ceccarelli, A. Grandi and S. Magagnoli (eds), Typicality in History: Tradition, Innovation and Terroir/La typicité dans l'histoire: tradition, innovation et terroir, Brussels: Peter Lang, 23-43.

Finn, M. (2017) Discriminating Taste: How Class Anxiety Created the American Food Revolution, Camden, NJ: Rutgers University Press.

Freidenreich, D. (2014) Foreigners and Their Food: Constructing Otherness in Jewish, Christian, and Islamic Law, Berkeley: University of California Press.

Geyzen, A. (2014) "Food studies and the heritage turn: a conceptual repertoire", Food E History 12(2): 67-96.

Grasseni, C. (2005) "Slow food, fast genes: timescapes of authenticity and innovation in the anthropology of food", Cambridge Anthropology 25(2): 79-94.

Grasseni, C. (2007) La reinvenzione del cibo. Culture del gusto fra tradizione e globalizzazione ai piedi delle Alpi,Verona: QuiEdit. 
Grasseni, C. (2013) “La patrimonializzazione del cibo. Prospettive critiche e convergenze 'sul campo"”, Voci 10: 87-110.

Hawkins, S. and Tanner, A. (2016) "Food, glorious food: the functions of food in British children's hospitals, 1852-1914", Food and History 14(1): 107-33.

Helstoski, C. (2008) Pizza: A Global History, London: Reaktion Books.

Holtzman, J.D. (2006) "Food and memory", Annual Review of Anthropology 35: 361-78.

Ichijo, A. and Ranta, R. (2015), Food, National Identity and Nationalism: From Everyday to Global Politics, New York: Springer.

Jones-Gailani, N. (2017) "Qahwa and kleiche: drinking coffee in oral history interviews with Iraqi women in diaspora", Global Food History 1: 84-100.

Jordan, J. (2015) Edible Memory: The Lure of Heirloom Tomatoes and Other Forgotten Foods, Chicago: University of Chicago Press.

Lakoff, R. (2006) "Identity à la carte: you are what you eat", Studies in Interactional Sociolinguistics 23: 142-65.

Laudan, R. (2013) Cuisine and Empire: Cooking in World History, Berkeley: University of California Press.

Leong-Salobir, A. (2011) Food Culture in Colonial Asia: A Taste of Empire, London: Routledge.

Lixinski, L. (2014) Intangible Cultural Heritage in International Law, Oxford: Oxford University Press.

Lloyd, P. (2015) Food and Identity in England, 1540-1640: Eating to Impress, London: Bloomsbury.

Long, M. (2013) Culinary Tourism, Lexington: University Press of Kentucky.

Maes, E., Vanhouche, A.-S., Scholliers, P. and Beyens, K. (2017) "A vehicle of punishment? Prison diets in Belgium circa 1900", Food, Culture and Society 1: 77-100.

Montanari, M. (1988) Alimentazione e cultura nel Medioevo, Roma-Bari: Laterza.

Montanari, M. (1993) La fame e l'abbondanza. Storia dell'alimentazione in Europa, Roma-Bari: Laterza.

Montanari, M. (ed.) (2002) Il mondo in cucina. Storia, identità, scambi, Roma: Laterza.

Nowak, Z. (2014) "Folklore, fakelore, history", Food, Culture \& Society: An International Journal of Multidisciplinary Research 17(1): 103-24.

Olmedo, E. (2015) Identity at Work: Ethnicity, Food and Power in the Malaysian Hospitality Industry, Singapore: Springer.

Parasecoli, F. (2017) Knowing Where It Comes From: Labeling Traditional Foods to Compete in a Global Market, Iowa City: University of Iowa Press.

Parker, T. (2015) Tasting French Terroir: The History of an Idea, Oakland: University of California Press.

Pearson, D. and Pearson, T. (2016) "Branding food culture: UNESCO Creative Cities of Gastronomy”, Journal of International Food E Agribusiness Marketing 2: 164-76.

Pfeilstetter, R. (2015) "Heritage entrepreneurship. Agency-driven promotion of the Mediterranean Diet in Spain”, International Journal of Heritage Studies 21(3): 215-31.

Pilcher, J. (2008) Food in World History, London: Routledge.

Ray, U. (2015) Culinary Culture in Colonial India: A Cosmopolitan Platter and the MiddleClass, Delhi: Cambridge University Press. 
Sammells, C.A. (2014) "Haute traditional cuisines: how UNESCO's List of Intangible Heritage links the cosmopolitan to the local", in R.L. Brulotte and M.A. di Giovine (eds), Edible Identities: Food as Cultural Heritage, London: Routledge, 141-58.

Scepi, G. and Petrillo, P.L. (2015) "The cultural dimension of the Mediterranean Diet as an Intangible Cultural Heritage of Humanity", in G.M. Molinelli (ed.), Cultural Heritage and Value Creation, Cham: Springer, 171-88.

Scholliers, P. (ed.) (2012) "Convergence and divergence in Europe since 1800. Cuisine of elites, bourgeoisie, and middle classes”, Special Issue Food and History: 3-209.

Segalla, S. (2016) Le radici del cibo: donne, trattorie, passaggi d'epoca, Milano: Guerini e Associati.

Stano, S. (2015) "From nutrients to foods: the alimentary imaginary of the Mediterranean Diet", ESSACHESS: Journal for Communication Studies 8(2): 115-32.

Sutton, D.E. (2006) Remembrance of Repasts. An Anthropology of Food and Memory, Oxford-New York: Bloomsbury.

Szabo, M. and Koch, S. (2017) Food, Masculinities, and Home: Interdisciplinary Perspectives, London: Bloomsbury.

Thomé-Ortiz, H. (2018) "Heritage cuisine and identity: free time and its relation to the social reproduction of local food", Journal of Heritage Tourism 13(2): 104-14.

Tichit, C. (2015) "Du repas familial au snack entre copains: le point de vue des enfants sur leur alimentation quotidienne (enquête en milieu scolaire à Paris, France)", Anthropology of Food 9. http://journals.openedition.org/aof/7883

Timothy, D. (2016) Heritage Cuisines: Traditions, Identities and Tourism, London: Routledge.

Tornatore, J.L. (2012) “Anthropology's payback: 'The Gastronomic Meal of the French'. The ethnographic elements of a heritage distinction", in R. Bendix, A. Eggert and A. Peselmann (eds), Heritage Regimes and the State, Göttingen: Universitätsverlag: 341-65.

Turmo, I., Verdù, J.M. and Navarrete, G.R. (2008) Alimentación y Dieta Mediterráneas. Patrimonio Cultural Inmaterial de la Humanidad, Sevilla: Consejería de Agricultura y Pesca.

Van den Eeckhout, P. (2013) "Cooks and waiters on the move: the World and International Exhibition in Ghent, 1913, as a destination for hospitality workers", Food and History 2: 287-316.

Vitrolles, D. (2011) "When Geographical Indication conflicts with food heritage protection: the case of Serrano cheese from Rio Grande do Sul, Brazil", Anthropology of Food 8. http://journals.openedition.org/aof/6809 


\title{
Tradition, heritage and intellectual property in the global food market
}

\author{
Fabio Parasecoli
}

\section{Introduction}

Champagne, parmigiano reggiano, Darjeeling tea. These are only a few among the traditional food products that have acquired particular relevance and visibility in the global food market. Their connection with history, a clearly identifiable geographical origin and unique manufacturing methods are highly regarded, allowing these items, usually produced in limited quantities, to gain reputation and command higher prices than similar goods. Furthermore, they may be considered as cultural expressions of whole communities rather than the brainchild of any one manufacturer. As these specialties attain wide recognition, the possibility arises that other producers may try to sell analogous goods of lesser quality or to use the same or similar-sounding names. To fight against counterfeits and copies, producers of high-reputation traditional goods have turned to the legal protection offered by Geographical Indications (GIs), a relatively new category of intellectual property (IP). Under the form of the privately owned trademark, this legal instrument had already been used to defend products as the expression of individual creativity and entrepreneurship.

This chapter reflects on how connections between tradition, heritage and intellectual property have been activated in the global food market. Intellectual property has acquired growing relevance in the identification, support and safeguarding of local and traditional food products. However, due to their legal nature and their regulatory structure, IP-based apparatuses risk stifling the evolution of food traditions, which by nature change and shift over time. Furthermore, they are not easy to establish for many communities, especially in the Global South, due to their complexity, their rootedness in Western juridical systems and the financial and logistic efforts they require. As traditional practices and products, as well as the products originating from them, are increasingly framed in terms of heritage, other approaches such as Slow Food's Presidia, UNESCO's Intangible Cultural Heritage $(\mathrm{ICH})$ and the new expanding field of Indigenous Knowledge (IK), are emerging. In this chapter I discuss the role and function of IP in supporting traditional and heritage foods, while assessing the limitations of such legal approaches and exploring alternative models that may be more flexible in determined contexts and environments. 


\section{Food, tradition and heritage}

Featured in media, popular culture, advertising, literature and film, food is now visible in cultural debates, social movements and political negotiations. In fact, food has moved to the forefront of public discourse. This new interest in what and how we eat, and in where what we eat comes from, is partly a consequence of the widespread perception that there is something wrong with our food system (Roberts 2008). In the past few decades, post-industrial societies, such as the United States, Western Europe and Japan, have seen their food production move more and more towards mass manufacturing, intensification and industrialization, a process which began at the end of the 19th century (Federico 2005). Many countries in the so-called Global South have embraced the same approach. Despite having lifted millions of individuals out of poverty by providing relatively accessible and affordable products, the global system is deeply problematic in terms of health and nutrition, social justice and long-term sustainability (Caparrós 2017; Greenberg 2010).

Against this background, among the most affluent strata of post-industrial societies purchasing choices play an increasingly important role in defining identities of individuals and communities. Rural and artisanal products and practices are embraced as cultural harbours that offer emotional sanctuary against globalization and its unstoppable circulation of goods, people, finance and ideas (DuPuis and Goodman 2005; Goodman and DuPuis 2002). Elements that in the past were cause for shame, such as the simplicity of dishes, the rusticity of ingredients and the connection with the rural and working-class social environments, have turned into major advantages in the processes of valuation that characterize contemporary foodie culture. These same elements are now woven into stories that provide depth and value to food consumption, well beyond quality and sensory appreciation. They play a central role in food consumer culture as an expression of what Pine and Gilmore defined as an "experience economy", in which the goals of production and business services are meant to provide customers not only with objects and services, but also with the experiences and memories that accompany them (Pine and Gilmore 1999). As a consequence, when it comes to food the value of a product is often determined not only by its inherent material and gustatory traits, but also by its meaning, its history and its rootedness in particular communities across the world, about which consumers can obtain information and knowledge. These dynamics provide consumers with a sense of connection with the origins of what they eat, compensating for a certain sense of loss. Among affluent foodies, traditions have emerged as among the most important features that help in coping with the dysfunctions of the contemporary food systems, even when such traditions are "updated" and "elevated" to better reflect the aesthetic and cultural expectations of those who can afford them.

In this chapter I refer to tradition both as a field of social action, something that people do, and as the object of such action. In the first sense, tradition 
is a system of values shaping the transmission of knowledge and the cultural reproduction of a social formation that, as a community of practice, shares and continuously negotiates ingredients, dishes, techniques and ideas about them in a specific setting (Polányi 1962). While tradition is a field of social action, the word also refers to the object of such action. Among the practices and customs from the past that are in some form still performed in the present, only a few are embraced and turned into objects of tradition, something that is acknowledged by a specific group of people or a community as a particularly relevant part of their past and valued as different and special, against the background of all that is considered less relevant or irrelevant. However, as Eric Hobsbawm observed, traditions are at times "invented", as a "response to novel situations which take the form of reference to old situations, or which establish their own past by quasi-obligatory repetition" (Hobsbawm 1983,1). The desire for food traditions is routinely exploited by unscrupulous advertising and marketing, building on the nostalgia for the good old days that may have never been experienced in the first place (Amilien, Fort and Ferras 2007; Bendix 1997; Zukin 2011). However, communities and individuals appear to understand that traditions change over time. The extent to which such alterations are deemed acceptable and not threatening is determined by discursive negotiations both within the community itself and with outsiders. Awareness - as limited as it may be - about the constructed nature of traditions, which often offer ideological legitimations to cultural, social and political formations, as well as the fact that traditions change over time, does not make them less emotionally real for those who partake in them.

As the past becomes something to prize and safeguard, a source of pride and an anchor for the survival of one's identity, a multiplicity of actors generate new shared connotations and habits around features of their present-day material culture. Tradition acquires further meaning and emotional weight as it is framed in terms of history, projecting present-day customs back into the past and attributing to them long-term duration and an influence on contemporary reality and its future. Tradition constitutes a form of temporality in which social actors create connections between their perceptions of the past, their experiences in the present and their expectations of the future. Through these expressions of historical consciousness individuals and communities articulate their social identity not only by locating themselves in time, but also by judging time (as good or bad, as crisis or hope, as real or false tradition). It is important to underline that such temporalities transcend individual experiences of time to constitute socially constructed discourses. Some histories (and stories) are privileged over others as the result of negotiations and interactions that take place at the level of material culture, practices and discourse, generating an economy of the past, in which fragments from previous periods are circulated, exchanged and valued in the present to shape the future.

Elements of food traditions - objects and practices - can be framed as heritage through the process often referred to as heritagization, in which specific 
institutions that are attributed authority to do so identify specific cultural elements, attach a particular value to them and include them in museums, registers or lists. Harrison describes heritagization as "the process by which objects and places are transformed from functional 'things' into objects of display and exhibition” (Harrison 2013, 69). Following Barbara Kirshemblatt-Gimblett (Kirshemblatt-Gimblett 1995), heritage is not something that is found, something that is there and just needs to be unearthed or discovered. Heritage is rather produced and constructed. Kirshemblatt-Gimblett argues that it is a mode of cultural production in the present that has recourse to the past, following motivations that have to do with current conditions. Heritage thus creates value-added industries and, in particular, produces the local for export. As in other cases, food is turned into heritage within specific national and international regimes and established by governments and actors such as the United Nations Educational, Scientific and Cultural Organization (UNESCO) (Bendix, Eggert and Peselmann 2013, 11-20). Furthermore, such regimes are enacted by institutions that are given the authority to identify heritage and to decide about the best methods to valorize and, in certain cases, to protect it.

\section{Intellectual property and the global food market}

As they enter the market, acquiring reputation and commercial value, traditional and heritage products have been ensnared in the legal categories of intellectual property, an altogether Western approach that nevertheless has forced itself well beyond the areas in which it originated.

Intellectual property started being used on food during the second half of the 19th century at a time when food industrialization in Western Europe expanded while increasingly larger segments of the population experienced an unprecedented process of urbanization. When they were not producing food themselves, people who lived in the countryside were used to being close to the places where what they ate came from and often personally knew the producers. They were able to understand the origin of their food and how it was produced. When they moved into the city, recently urbanized consumers experienced anxiety about their purchases, in part because counterfeiting and adulteration were common practices, forcing city authorities to police markets and to establish specialized science laboratories to check for biological and chemical hazards (Atkins, Lummel and Oddy 2007; Stanziani 2006).

Intellectual property partly appeared and was applied to food to establish guarantees about the quality of goods and their origins. The first were trademarks, which identified specific products as belonging to or produced by a specific company. New ways of connecting products with their places of origin also emerged, generating the specific kind of IP that now we call GIs. In 1855 a system that classified Bordeaux wines - and implicitly the estates (chateaux) that produced them - was formalized in France, defining five levels of relevance and worth known as cru, the French word for "growth". This is usually indicated as 
the first instance of the concept that would in time support the development of GIs, an approach that was already fully formed during the 20th century and that was eventually codified in the international convention called Agreement on Trade-Related Aspects of Intellectual Property Rights (TRIPS), the agreement of the World Trade Organization (WTO) that deals with IP. This document, signed in 1994 as one of the founding documents of the WTO, was the result of negotiations between the European Union, which in 1992 had already launched its own legal scheme of GIs, separate and distinct from other forms of IP, and other countries, such as the United States, Australia and Argentina, which instead extended the already existing system of trademarks and collective marks to cover traditional and heritage foods which enjoyed much less prestige, recognition and economic values than in Europe in the first place.

Trademarks are considered business assets and the private property of one specific company that, as such, can be transferred and sold. As they do not imply any connection to specific traditions, communities or places of origin, trademarks can be invented words, included in logos or used to protect brand names. Collective marks instead designate goods that are linked to and represented by an association, a board or a group of producers. These own the mark collectively and determine the quality standards and the procedures for using it, often reflecting quality elements that consumers may find important. Collective marks can be used as a form of GI when a requirement for their use is the origin of a product in a specific place. However, they do not refer to cultural elements such as tradition and heritage, which are much more complex to pinpoint and to certify. The United States has introduced a third category, known as certification marks. Well-known denominations such as Vidalia onions and Florida citrus fall under this category. They are called certification marks because they do not belong to the producers themselves, but to a thirdparty certifying entity, often state institutions such as Georgia's Department of Agriculture (owner of Vidalia onions) and Florida's Department of Citrus (owner of Florida citrus), which sets standards, characteristics and requirements that users of the marks must meet. As long as these products present such prerequisites, their producers have the right to use the certification marks. Certification marks function as forms of GI when the origin in a specific area is one of the requirements for their use. Countries that use the already existing mark system to identify and to protect traditional and heritage products - often with reference to their place of origin without any consideration for cultural elements -consider this approach sufficient and efficient because it provides a familiar framework to producers. As owners of the marks have the prerogative to take action against infringement, the system saves public funds and administrative resources.

As already mentioned, in 1992 the European Union established a new scheme that embraced a different approach that required specific legislation, distinct from laws regulating intellectual property instruments such as marks. For this reason, the EU system is often referred to as sui generis, meaning of its own 
kind. It is constituted by tiers - Protected Designation of Origin (PDO) and Protected Geographical Indication (PGI) - that present different requirements in terms of connections to specific places and methods, reflecting tradition and local cultures (May, Sidali, Spiller and Tschofen 2017). Other countries, such as India and Costa Rica, have adopted sui generis systems. In Canada, the federal government has adopted a mark-based system, while the state of Quebec, which is very connected to France culturally and historically, has its own sort of GI sui generis system for local, traditional products.

\section{The limits of the intellectual property approach}

Overall, the success of protection of food under IP, in the form of either sui generis GIs or mark-based systems, depends on many circumstances and factors, such as social and political dynamics at the local level (including labour relations and power structures) and the cultural attitudes of all the entities involved, as well as the participation of public institutions, private agencies and nongovernmental organizations (NGOs).

Any consideration of GIs needs to be understood within a larger critical assessment of IP as a Western legal framework that was more or less subtly imposed on non-European countries during colonization and, later, through international conventions, trade agreements and the pervasiveness of Western economic and financial instruments that are central to the smooth functioning of the contemporary food system (Arewa 2006). Such approaches are based on written documents, both as core instruments in Western law methods and procedures, and as proofs of the historical past of a product and its connection to long-lasting traditions. As a consequence, traditions rooted in communities that in the past were left at the margins of mainstream society and often without access to education and literacy, such as women and ethnic minorities, are difficult to prove. Furthermore, cultures existed and still exist that are based on oral transmission of knowledge, which makes the written nature of IP problematic.

In general, local political and social arrangements play an important role in determining which producers and their associations obtain financial and political support in their efforts to launch a Geographical Indication. Intellectual property-based systems are usually rather difficult to establish for communities, especially in the Global South. Legal and administrative costs as well as logistical difficulties related to the establishment of a GI may discourage some producers from even considering the possibility of using this instrument.

Geographical Indications are complex instruments that producers occasionally may not understand in terms of their function and possible advantages. At times national governments decide to adopt an IP system to comply with international requirements or simply to establish a framework of action for the future. In that case, local communities may need the intervention of various private and public institutions, NGOs and agricultural research universities to adopt and use them. In the state of Karnataka, in southern India, the Department 


\section{Geographical Indications in the world}

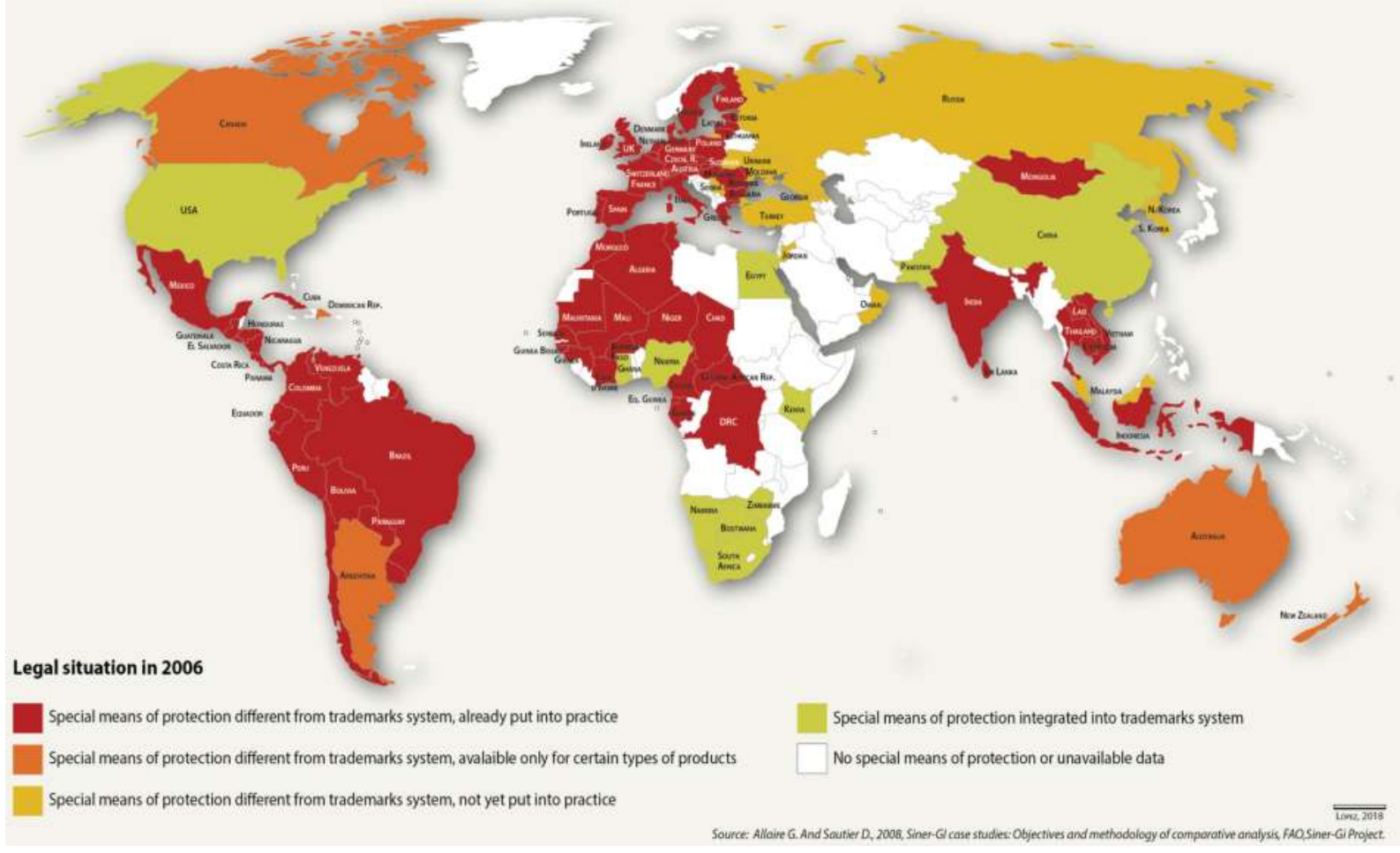

Figure 3.I Geographical Indications in the World 
of Horticulture collaborates with NGOs to gather information about local products and to identify those with the potential to become GIs, based on their characteristics, quality and cultural relevance in terms of local tradition. The Department of Horticulture also supports the formation of producers' associations, covers the administrative costs to put together the dossier for a GI request, coordinates extension programmes and collaborates with media and chambers of commerce to provide visibility to the products after a GI has been obtained. In Thailand, where the IP law for GI was issued in 2003 and the concept is not yet familiar among producers, the Department of Intellectual Property reached out to the Ministry of Agriculture and local authorities to organize a tour to pinpoint possible GIs, which resulted in the establishment of several of them.

The very concept of GI may also be unfamiliar to the less developed countries because large sectors of the population may be uninterested or too poor to afford products protected by IP.They consequently tend to be sold mainly in high-end urban or international markets. Such a state of affairs is quite ironic, considering that many foods that enjoy IP protection get higher value precisely from their connection to traditions and heritage elements that are embedded in the culture of local, often rural, communities.

Ingredients, dishes and practices inevitably shift and develop over time. However, the ever-changing nature of tradition finds itself inherently in tension with the legal apparatus of GIs based on IP (both in sui generis and in markbased systems), as they are tied to legally binding rules and run the risk of stifling the otherwise inevitable evolutions of products. Once the set of requirements necessary to establish a GI is negotiated and decided upon among the producers involved in the process, they determine that materials have to come from a specific area and be manufactured according to detailed techniques and methods, and that the final product has to look a certain way. While these elements better define products and make them more recognizable on the global market, from the cultural point of view they actually prevent them from changing over time, as has always happened throughout history. Left alone, products and practices react to transformations in their environment and in the social dynamics in which they are embedded. Most IP regulations include clauses that allow for some minor changes over time, as long as they are approved by the associations of producers behind the sui generis GI or the mark. However, such procedures inevitably tend to slow down any sort of transformation that might otherwise take place.

\section{Models not based on intellectual property}

Reacting to the limits and the critique levelled towards the use of IP on traditional foods, new approaches are being developed that are supposed to identify, valorize, support and at times even protect ingredients, dishes and practices.

In 1999, the international association Slow Food, the goal of which is to advocate for "good, clean, and fair" food, introduced the Presidia project. Presidia started as an applied, practical arm of the Ark of Taste, an initiative launched to identify and to support traditional products, methods, rural landscapes and 
ecosystems that are at risk of disappearing. However, unlike in the case of GIs, Presidia emphasizes producers and the communities to which they belong rather than just the place of origin of products and their name. Slow Food realizes that traditional foods and crops that require labour-intensive production methods and may wield low yields need to be sold at sufficiently high prices to remain viable and to ensure a decent livelihood for producers. Such specialties often find a global market among food enthusiasts who are curious about unfamiliar ingredients, dishes and the practices that underlie them, while also having the financial means to afford them. Paradoxically, in the case of Presidia, the local, traditional dimension survives thanks to the global, modern one, revealing they are in fact different manifestations of the same phenomenon. Traditional products acquire commercial value precisely if and when they are globalized.

Through Presidia, Slow Food has been trying to establish a new template to support traditional products by shifting from occasionally overwhelming and financially challenging legal regulations to activities, media and marketing based on community dynamics and connections among the members of the association. Slow Food has created a language that resonates among those consumers and producers who give relevance to food as an expression of culture, social values and political vision. Reputation and recognition from both the general public and professionals (distributors, shopkeepers and chefs), along with the interest of media operators and cultural mediators, can ensure market penetration and the economic profitability of products that, due to lack of efficiency in terms of technology and productivity, could not survive on the market.

Moreover, the association has been able to develop effective communication networks that include print and social media. The quality, sensory characteristics and personal stories of individual producers and the communities in which they are embedded are highlighted and made available to conscious and committed consumers. From this point of view, Presidia products are a perfect example of the dynamics of the experience economy and new forms of valuation that go beyond the materiality of objects and services. At the same time, Presidia can also be considered as a form of heritagization: using Kirshemblatt-Gimblett's conceptual framework, intentional social activities are organized around objects and practices that have their root in the past but are operationalized to respond to present circumstances and to ensure economic income in the future. Elements of culinary culture are identified and highlighted as deserving special protection, reflecting processes of valuation that emerge from the new centrality of food and food traditions among growing segments of culinary enthusiasts around the world.

The emphasis on history, culture and reproduction of local communities, outside the international legal frameworks regulating trade and intellectual property, is not limited to civil society organizations such as Slow Food. Over the past decades, the international organizations UNESCO and the United Nations Food and Agriculture Organization (FAO), have established their own mechanisms to identify and to safeguard food-related traditional practices, 
Slow Food - Ark of Taste

International catalogue of endangered heritage foods designed to preserve at-risk foods that are sustainably produced, unique in taste, and part of a distinct ecoregion.

Number of products

by country

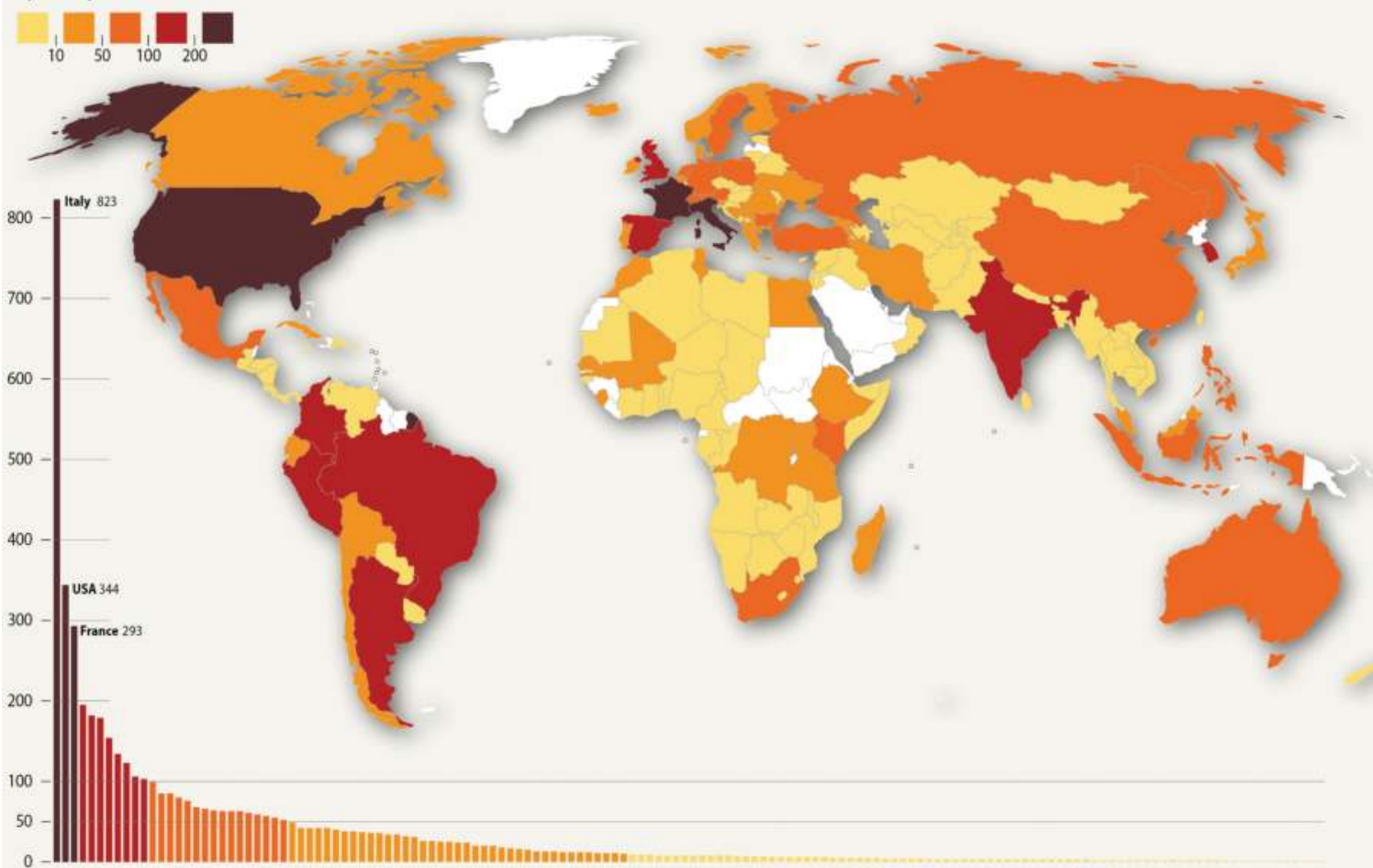

Figure 3.2 Slow Food - Ark of Taste 
knowledge and landscapes, the value of which is not immediately measurable in terms of economic profitability but is framed instead in terms of heritage.

Since 2010, UNESCO has incorporated food-related practices into its list of Intangible Cultural Heritage (ICH). This is the outcome of a long-term shift that has been taking place in the international organization. While at its inception, following the destruction of World War II, monuments and architecture were its main interests, "cultural landscapes" were added to the "World Heritage" list in 1992. Representing the interactions between human communities and the environment in which they settled, they are now included in the UNESCO list as having "outstanding universal value" and exceptional significance for all of humanity, and not only for the countries in which they are located. The list of cultural landscapes includes agricultural settings such as the rice terraces of the Philippines Cordilleras, the archaeological landscape of the first coffee plantations in the south-east of Cuba and the Alto Douro wine region in Portugal. Such agrobiodiversity was selected and emphasized in terms of heritage, with the goal to ensure its survival in the future through greater visibility. However, indirectly it has the potential to generate economic windfalls in terms of tourism and sales of the products from those areas.

Following the UNESCO approach and trying to counteract the global crisis of traditional agricultural systems, especially in developing countries, in 2002 the FAO launched a new initiative to identify and to support the conservation of productive landscapes through adaptive management under the Globally Important Agricultural Heritage Systems (GIAHS) initiative. Just like the UNESCO cultural landscapes, GIAHS need to be universally significant in terms of agrobiodiversity to be added to the FAO list; moreover, they have to be relevant for food security and transmission of culture. Among them, we can mention the Andean agriculture system in the Cuzco-Puno corridor, Peru; the rice fish culture in Qintian County, China; and the oases of the Maghreb in El Oued, Algeria, and Gafsa, Tunisia.

Since 2010 UNESCO has also added food-related practices to its ICH list. The list comprises not so much dishes or ingredients, but rather practices and the culture that surrounds them: what the community does and thinks about its production, preparation and consumption of food. While the element of intergenerational transmission is of the utmost importance, transformation is considered a fundamental feature for this kind of heritage, unlike the categories defined in the IP framework. In other words, practices, knowledge and skills cannot be kept unchanged, frozen in time or converted into museum elements: they are constantly evolving to respond to new situations. To qualify for the UNESCO list, heritage must be a living expression of the embodied experience of a community, with its shared sense of identity and continuity. However, it should not promote intolerance and discrimination against outsiders, but rather inspire intercultural communication.

The first three food-related traditions inscribed on the UNESCO ICH list in 2010 were the Gastronomic Meal of the French, the Mediterranean Diet 
(proposed by Italy, Spain, Morocco and Greece) and traditional Mexican cuisine (ancestral, ongoing community culture, the Michoacán paradigm). Since 2010 many others have been added. For example, in 2017 UNESCO added the "Art of Neapolitan Pizzaiuolo" (Italy), making and sharing of dolma (small fillings wrapped in fresh or pre-cooked leaves or stuffed in fruits and vegetables) in Azerbaijan and the Nsima corn porridge tradition in Malawi.

As in the case of the Slow Food Presidia, the UNESCO and FAO schemes do not have the legal weight and immediate effects on GIs, which are based on enforceable national and international IP regulations. The initiatives, created within the framework of the United Nations, do not emerge from advocacy, activist networks or associations in civil society, but are rather based on local implementation and the involvement of local authorities and stakeholders around the concept of heritage as cultural transmission of practices and agrobiodiversity, as elaborated in the international organizations. Such approaches have also provided the base for the emerging category of Indigenous Knowledge (IK), which was already present in the convention of biological diversity from 1992 and was systematized in 2010 with the Nagoya protocol. The category refers to forms of knowledge that have been handed down in a community through generations, sometimes in isolation from the rest of the country where they are located, and may include the cultivation and transformation of plants with noticeable nutritional or pharmaceutical value. In the past, foreign companies could easily send bio-prospectors charged with exploring little-known environments to find natural compounds or genetic material with good commercial potential; when they located something of interest, their company would trademark and commercialize the product, while completely excluding the communities in which they had been found from any income deriving from sales. The 2010 Nagoya protocol provides rules for accessing IK and sharing benefits that may derive from it in the form of royalties or compensation for various services. Agreements can now be signed between foreign companies, a community and a third party that work as guarantor, possibly connected with research centres, universities or other public institutions. Although these practices are not explicitly referred to as heritage, they are easily recognizable as such: an activity in the present that has recourse in the past. Indigenous Knowledge is central in cultures that do not necessarily use literacy as a form of skill and agrobiodiversity transmission; in the absence of written documents and written laws, it is difficult to harmonize IK and the IP labels that may be based on it, such as trademarks or GIs. However, within the World Intellectual Property Organization (WIPO) a committee has been established precisely to study how to proceed towards this harmonization.

\section{The future of food traditions and heritage}

Global food trade is changing in terms of market regulations and financialization of food commodities, while climate change and other environmental issues 
become more urgent. New actors have acquired relevance in determining the availability and prices of food, such as stockbrokers, financial investors, hedge funds and sovereign funds. In this context, policies implemented by local and national authorities must be harmonized with regional, bilateral and multilateral trade agreements that address matters as diverse as subsidies, food security and the survival of rural communities. At the same time, consumer preferences are also changing: food is becoming an increasingly important element in constructing individual and collective identities in post-industrial societies. Quality of ingredients and dishes is appreciated along with their uniqueness and the experiences associated with their consumption.

In this context, several instruments have emerged in IP law, activism, civil society and cultural protection which contribute to identifying, safeguarding and supporting food traditions, often framed in terms of heritage. These food-related elements have gained unprecedented visibility and sale potential, as new forms of valuation stimulate consumers with higher purchasing power to pay premium prices. Manufacturers also believe that the specificities of their goods constitute an opportunity to differentiate them from the low prices of commodity markets and to move them into more profitable niches where higher prices are the norm.

The presence of products and practices that benefit from instruments like GIs, Slow Food Presidia, UNESCO ICH and IK inevitably affects the economic activity, labour relations and sustainability of the communities in which such elements are embedded. Traditions and heritage never limit themselves to reflecting existing realities, but actually contribute to shaping them.

Heritagization processes and their instruments can generate very different dynamics, deepening inequalities or improving the distribution of resources and income within a community.The results depend on many factors, including natural resources; availability of know-how and craft skills related to traditional productions; power relations from a social, financial and political point of view; and connection with entities ranging from local authorities and national governments to international organizations and NGOs.

A careful assessment of these factors should help in determining which instruments are best suited, also considering that the same product or practice can potentially be covered by several of them. A cheese production can in theory be identified as IK or deemed worthy of inclusion on the UNESCO ICH list, while being protected by an IP-based GI and supported by the marketing and communication that characterize Slow Food Presidia. Of course, such opportunities require levels of savvy and political skills that unfortunately are not common in underprivileged communities, which would most benefit from these mechanisms.

Research and cooperation between local communities, academics and institutional actors is crucial to identifying, assessing and supporting local resources that could remain invisible - both to consumers and to decision makers - due to cultural and social barriers, despite their quality and value. These and other issues should be openly discussed, not only in scholarly circles and in advocacy, but also in domestic and international political centres if protection of food 
tradition and heritagization are to reach their full potential to enhance innovative, just and sustainable forms of production, while disseminating scientific information, technological knowledge and management skills in communities where such elements may be sorely needed.

\section{References}

Amilien, V., Fort, F. and Ferras, N. (2007) "Hyper-real territories and urban markets", Anthropology of Food S2. Accessed 20 December 2018. http://aof.revues.org/document446.html

Arewa, O. (2006) “TRIPS and traditional knowledge: local communities, local knowledge, and global intellectual property frameworks", Marquette Intellectual Property Law Review 10(2): 155-80.

Atkins, J.P., Lummel, P. and Oddy, D (eds) (2007) Food and the City in Europe since 1800, Aldershot: Ashgate.

Bendix, R. (1997) In Search of Authenticity: The Formation of Folklore Studies, Madison: University of Wisconsin Press.

Bendix, R., Eggert, A. and Peselmann, A. (eds) (2013) Heritage Regimes and the State, Göttingen: Universitätsverlag Göttingen.

Caparrós, M. (2017) Hunger: The Mortal Crisis of Our Time, New York: Other Press.

DuPuis, M. and Goodman, D. (2005) 'Should we go 'home' to eat? Toward a reflexive politics of localism," Journal of Rural Studies 21(3): 359-71.

Federico, G. (2005) Feeding the World: An Economic History of Agriculture, 1800-2000, Princeton, NJ: Princeton University Press.

Goodman, D. and DuPuis, M. (2002) "Knowing food and growing food: beyond the production-consumption debate in the sociology of agriculture", Sociologia Ruralis 42(1): 6-23.

Greenberg,P. (2010) Four Fish: The Future of the LastWild Food, New York: Penguin Books. Harrison, R. (2013) Heritage: Critical Approaches, New York: Routledge.

Hobsbawm, E. (1983) "Introduction: inventing tradition", in E. Hobsbawm and T. Ranger (eds), The Invention of Tradition, Cambridge: Cambridge University Press, 1-14. Kirshemblatt-Gimblett, B. (1995) “Theorizing heritage”, Ethnomusicology 39(3): 367-80.

May, S., Sidali, K., Spiller, A. and Tschofen, B. (eds) (2017) Taste, Power, Tradition. Geographical Indications as Cultural Property, Göttingen: Universitätsverlag Göttingen.

Pine, J. and Gilmore, J. (1999) The Experience Economy: Work Is Theater and Every Business a Stage, Cambridge, MA: Harvard Business School Press.

Polányi, M. (1962) Personal Knowledge: Towards a Post-Critical Philosophy, London: Routledge and Kegan Paul.

Roberts, P. (2008) The End of Food, New York: Mariner Books.

Stanziani, A. (2006) "Histoire de la qualité alimentaire", Food and History 4(1): 307-44.

Zukin, S. (2011) "Reconstructing the authenticity of place", Theory and Society 40(2): 161-5. 


\title{
Food and locality \\ Heritagization and commercial use of the past
}

\author{
Paolo Capuzzo
}

\section{Geographical roots of food?}

Identifying a food culture with a locality has always involved a trade-off between searching for roots and recognizing they are not planted in any one spot but entail exchanges and borrowings from remote origins. But even this tension between the local and the supralocal is a simplification: it rests on the assumption that food cultures can be identified by place alone. Actually, highly different food regimes may be at work in one and the same place, and have been so in the past. Class stratification may afford a first prism dividing up food culture domains, but it then interweaves with gender, religious observance, ethnic belonging and so on.

Does this mean that any attempt to find a relationship between food and place is a waste of effort? No, indeed: such a relationship can definitely be established. But one does need a critical analysis of the various factors bearing on the link between food and place, since they are cultural and historical constructs rather than causal connections between milieus in nature/history and food cultures.

A cuisine rich in victuals of different kinds, prepared from a wide range of ingredients at times exotic in provenance, was typical of the food culture found in the courts of Europe from the late Middle Ages to the early modern era; the diet of the people was more closely locally connected, perforce. For most of the population poverty dictated the choice of diet.

A plentiful cosmopolitan cuisine reigned at court (Montanari 2014); it was garnished with rare and exotic ingredients indicating wealth, though also a background of culture deriving from greater familiarity with distant lands. The omnivorous court bracketed produce and specialities from the most disparate places under one gastronomic pantheon. The provenance factor did not point to a single relationship between the food and a specific place, but created a variegated exotic aura around a rich culinary spread.

The first question is therefore when an exclusive relationship began between food and geographical provenance. This is far from simple, for that connection has taken on quite different meanings in the variety of historical contexts. 
In the 15th century Libro de arte coquinaria, thought to be one of the texts ushering in the Renaissance diet, Maestro Martino rarely identifies foods by their place of origin (Martino 2001). There are cases where he does, of course: we find mirrause catalano, a "half roast" already cited in one of Europe's oldest recipe books, the Libre de totes maneres de potatges de menjar, an anonymous manuscript from 1324 which Maestro Martino may have come across during his stay at Naples. There is also talk of coppiette al modo romano, maccaroni romaneschi, cavoli alla romanesca, maccaroni siciliani, bolognese pie, ova frictellate a la fiorentina, starne al modo catalano and minestre alla catalana. Yet many of these names do not trace back to a consolidated local style of preparation: they were quite accidentally linked to how Martino came across them. They did not form a consistent gastronomic geography linking raw materials, customs and recipes to any specific place.

In later centuries place names defining foods became more common. In France, which made an early start with political centralization and territorial integration, a series of mid-17th-century treatises and recipe books - with François Pierre de la Varenne's 1651 Le cuisinier françois to the fore - began to call a national style of cooking "French" (de la Varenne 2001). This mode of definition by nation came to prevail in the 19th century, conferring an inward-looking and an outward-looking dimension on geography. Inwards, the national frame led to "regional cuisines" emerging as a factor of abundance, or one looked outward to compare with or distinguish from other national cuisines.

De la Varenne's book makes extremely rare reference to local recipes. French cuisine means that of Paris; the capital is not just the symbol of French unity, but also the only place where resources from all over France were available, with the court based there, the city consumers prosperous and the whole French transport system radiating from the capital (Abad 2002).

One century later more and more references emerged to the lands contributing to the abundance and prestige of the national cuisine. Dishes began to be cooked in Provençal, Flemish or Burgundian style if French; Milanese, Genoese and Neapolitan style if Italian. Such dishes refer to specific ingredients and styles of preparation, but do not yet amount to a consistent picture of regional cuisines (Csergo 2007).

The first great fascinating tour of French gastronomic areas was published in 1782 with the first edition of Histoire de la vie privée des français depuis l'origine de la nation jusqu'à nos jours by Pierre Jean-Baptiste Legrand d'Aussy (1782). Paris continued to unite and symbolize the wealth of a national cuisine whose identity is based on a model composed of regions. We thus see a blend between the high model spreading from the court to the urban bourgeoisie, and a low model bringing a wealth of popular cooking tradition from the provinces (Parkhurst Ferguson 2004).

In Italy, where national unification came later, the rift between the elite and the people was far more marked than in France. The diet of the new Italy's elite 
shows that France was gastronomically in the lead, as in many other European countries. A national reaction against French gastronomy set in during the late 19th century in many European countries from Germany to Spain. French influence was accused of preventing the deep spirit of national cookery from reviving (Storm 2016). Hence the appearance of national recipe books, such as Emilia Pardo Bazán's La cocina española moderna, stemming from a careful ethnographic survey hymning the national spirit and exploring its regional gastronomic traditions (Pardo Bazán 1913; Paz Moreno 2006).

The Italian 19th century saw recipe books referring to specific places, though they continued to be heavily influenced by French cuisine. No serious survey of local food cultures took place; local dishes were branded as specialities when they were actually common to many regions (Capatti and Montanari 1999; Meldini 1997).

If we take the 1874 Cuciniera bolognese, a reprint of a book that came out in 1857 under the title Il cuoco bolognese, we find a gamut of French recipes and various Italian specialities, but no mention of tagliatelle al ragù or tortellini; on the other hand, sfrappole and crescentine are listed, which shows some connection with local cooking. In the same years there were similar examples such as Il cuoco milanese e la cuciniera piemontese: manuale di cucina indispensabile per ogni ceto di famiglia (1859). Replacing "chef" with "cook" (cuciniera) is typical of many late 19th-century publications and marks a clear shift in the destination of recipe books: they were no longer confined to "male professionals", but designed for middle-class ladies aiming to improve the preparation of food in the family and when guests were invited (Coveri 2012; Ratto 2004). This was the public that Pellegrino Artusi addressed.

Artusi's La scienza in cucina e l'arte di mangiar bene, which is rightly or wrongly taken as the book that unified Italian gastronomy, is based on a very limited portion of Italy. Half of Artusi's recipes come from Emilia, Romagna and Tuscany, and the other areas are only explored as and when the Italian railway network expanded to cover them.

In 100 specialità di cucina italiane ed estere (1908) we read that "just as each of our regions has had a school and character of its own in painting, sculpture, architecture, etc., so in the way of preparing food, the culinary art, each part of Italy has specialities all its own." But again, although the recipes are classified by city, there are some rather generic attributions and a failure to mention certain dishes that would shortly become icons of their region. Thus we have tagliatelle at Bologna, but not tortellini; pesto is missing from Genoa; Roman cuisine lacks all typical features; calf's head à la Livornese appears among Piedmontese dishes.

Abroad too at this time there seems to be little interest in connecting food with place. The German journalist Hans Barth takes the reader on a cultured tour of taverns in the main Italian cities from Verona to Capri. Yet his guide contains the briefest of generic information about food and wine; he is more detailed on beer, and waxes long and anecdotal on popular eating places in the sections devoted to city architecture and history (Barth 1908). 


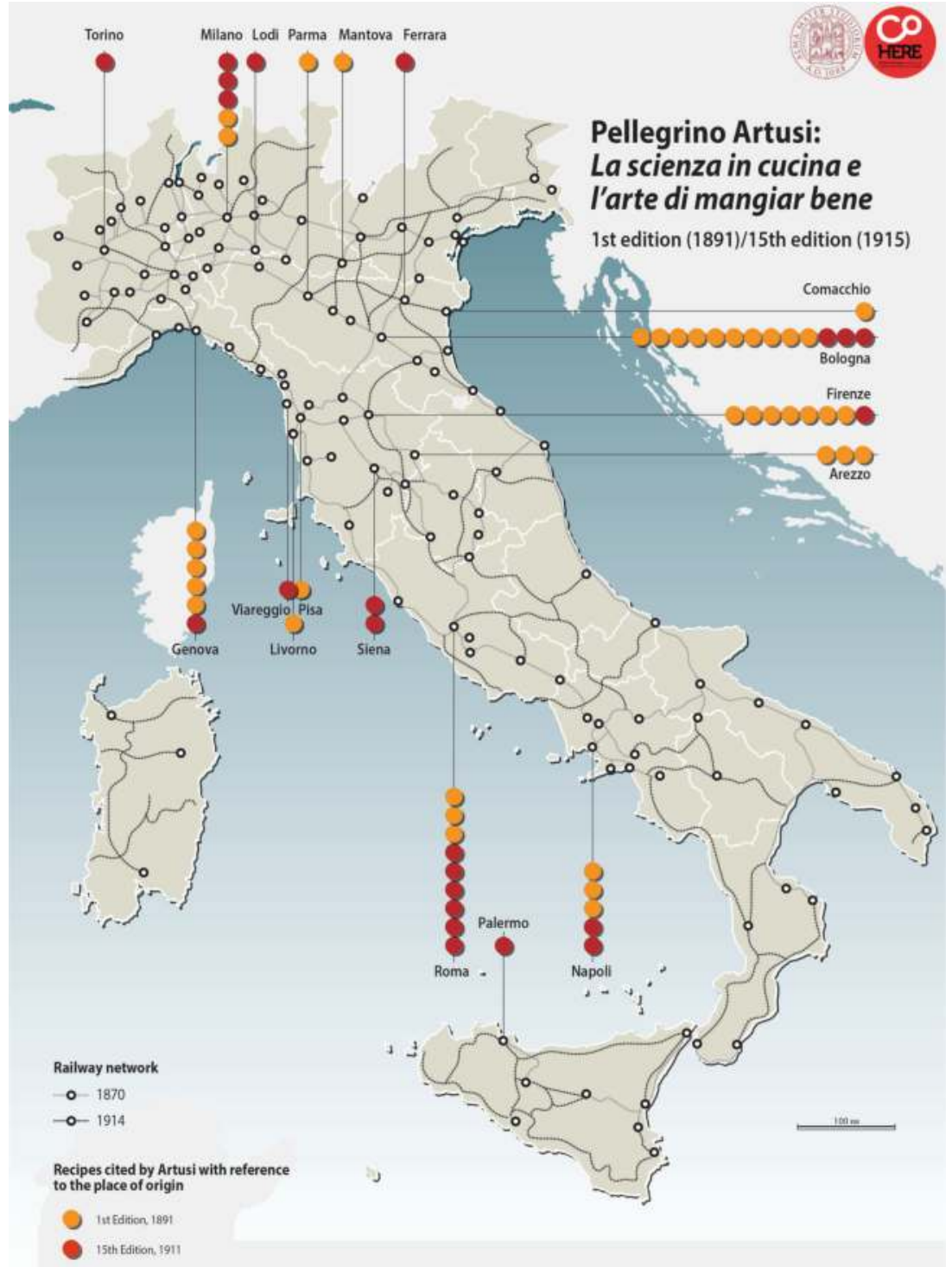

Figure 4.I Pellegrino Artusi, La scienza in cucina e l'arte di mangiar bene. Recipes. Place of origin 


\section{Peoples and regions}

In the decades straddling 1900 a new interest arose in the people and their culture, manifested in research into folklore, art and literature. Within this cultural framework regional cuisine began to be considered as an expression of culture and social customs rooted and established in an environment.

The 25 volumes comprising the Biblioteca delle tradizioni popolari siciliane (Library of Sicilian Popular Traditions), published by Giuseppe Pitré between 1871 and 1913, never take food as a specific topic. Where it does constantly appear is in the words of songs, folk tales and other stories, as well as in the description of festivities and popular customs and language. The people gained recognition for their own culture, a basic part of which was seen to be diet and cuisine.

Thus, while there was growing attention to the local, as part of a cultural heritage including popular traditions, "high culture" kept its national or European character, while the regional themes now being put forward by small pockets of provincial intellectuals had an important role in building regional identity. To most of the Italian population the region was a more artificial entity than the nation for which Risorgimento rhetoric and post-unification state school education had created an identity basis via cultural and educational institutions. So the idea of identifying food by its region of origin was far from trite.

The conditions for regionalism gaining greater visibility coincided with the beginning of the 20th century. Regionalism steadily took on an anti-academic profile in line with the intellectual stance of a new generation belonging inside the anti-Giolitti political archipelago. Such provincial intellectuals were given a voice by a highly influential periodical interpreting the cultural turn under the apt name of La voce. Among such young intellectuals was a gamut of political leanings, going from an intellectual of European stature like Renato Serra (Raimondi 1993), to writers interpreting the provinces in outspokenly nationalist tones, like Curzio Malaparte. A welter of regional journals combined economic and political information with an interest in folklore and local traditions. Some of them formed the mouthpiece of associations or museums that were active in the neighbourhood. Even the great national myth of the Risorgimento began to be reappraised for its local dimensions, while antiquarian studies turned their sights on the remote origins of the regions (Cavazza 1997; Porciani 1996).

Parallel with this interest in the provinces, literature increasingly focused on "the people", often romanticizing them: from the slums of Naples seen through Francesco Mastriani and Matilde Serao, to the Sicilians GiovanniVerga, Luigi Capuana and Federico de Roberto, the Calabrian Nicola Misasi and the Tuscans Renato Fucini, Ferdinando Martini and Mario Pratesi (Asor Rosa 1966). Though of differing approach and artistic value, these writers' works fuelled the distinction between "popular poetry" stemming from the people, rooted in a landscape and expressing a historical legacy fed by customs and oral traditions and now brought to light by artists, and "cultural poetry" (poesia 
d'arte) as studied at the academies. Benedetto Croce would shoot down that distinction, only admitting the difference between art and non-art (Croce 1929), but it was nonetheless being scientifically validated by studies in folklore, demology, linguistics and glottology. Such milieus were largely conservative in their political leaning, or embraced a form of humanist socialism blended with Christian piety and quite different from what was then called "scientific socialism" with its pronounced internationalist vocation.

In the academic milieu interest in folklore developed out of ethnology and demology. At the 50th anniversary of Italian unification in 1911 an important exhibition was held in Rome on "Italian ethnography", promoted by Lamberto Loria, the founder of the Società di Etnografia Italiana (Puccini 2005). On show were a series of items meant to represent the regional character of Italian popular cultures. These were eked out by materials from the Florentine Museum of Ethnography, the first nucleus of the National Museum of Popular Art and Traditions that came into being almost half a century later. The year 1909 had seen the birth of another ethnographic museum, that of Palermo created by Giuseppe Pitré.

These threads came together to foster the idea of the region as a linchpin in a renewed national movement, which enjoyed champions such as the marquis Giovanni Crocioni, whose cultural, political and educational interests espoused the region as a building block in national identity. Regional identity, they saw, strengthened Italian identity, and thus found favour with the strongly patriotic side to Fascism, as well as promising a new alternative to "cosmopolitan American-style" modernity. Reviving "local traditions" figured in the drive to modernize Italy's tourist infrastructure. "Popular fêtes" would be exhumed, adapted and more or less invented; they proved to be one of totalitarianism's favourite ways of organizing people's free time.

\section{The "birth" of regional cuisines}

It is important to realize that systematic attention to the regional aspect of cookery was the result of these broader cultural and political transformations.

Vittorio Agnetti's 1910 recipe book surveys the regional varieties of Italian gastronomy and shows how cooking conformed to locality, that is to say, places endowed with environmental and cultural consistency. Agnetti's voyage of discovery in quest of "popular regions" was designed to hymn the riches of national cuisine: "from the somewhat German inhabitants of Friuli to the somewhat Arab ones of Sicily we see the widest variety both of physical structure and of taste preferences". It is thanks to that diversity that "our national cuisine, though almost entirely unknown, far outstrips in variety and excellence the far-famed French cuisine" (Agnetti 1910, 5-6). Such nationalistic trumpetblowing does not omit the hybrid territories to the north and the south; that aspect would be lost in the touring guide's systematization of regional cuisines occurring in the high Fascist period. 
In reviewing the Italian regions, Agnetti presents a Piedmont under French influence, though beginning to emancipate itself: the French fondue is now seen as an "insipid hors d'oeuvre", and has turned into the more refined and filling fondua. The Ligurian section opens with pesto, while the cooking in Lombardy is "if not the best, the most widespread and best-known especially abroad. The many Italian restaurants in Paris, London andVienna serve nothing but Lombard dishes" (Agnetti 1910, 29). Risotto, cotoletta alla milanese, ossobuco, frittura piccata, panettone and torrone are pinnacles of Lombard cuisine. But Agnetti's regional coverage is still incomplete: Artusi stopped at Naples; Agnetti gets as far as Sicily and Sardinia, but makes no reference to Calabria, Puglia, Basilicata, Abruzzo, Umbria and Marche. The lion's share goes to Emilia Romagna and Tuscany, showing how Agnetti depends on Artusi's geographical selection. Rome figures in Agnetti's guide but fails to shape the national diet: where regional diversity in France is measured against the unquestioned lead of a central Paris, Italy has no such pattern and appears more uncertain, a bundle of territories lacking any clear hierarchy.

Alberto Cougnet's weighty treatise enlarges on local cuisines as part of its overt anthropological interest in cookery. It draws its examples from far and wide, even outside Europe. But its panorama of Italy never strays beyond the centre north (Cougnet 1910). ${ }^{1}$ Of course, many parts of the inland south were still fairly inaccessible and off the tourist route for which gastronomic guides now catered.

From a clean rift between the aristocracy's cosmopolitan tastes and a popular style of local/regional culture, the rising middle class took on the role of "representative of the people" and became the force behind modernization of the country's tourism and infrastructure. The emergence of regional cuisines thus came to affect the catering sector. Where France had dominated the entire 19th century, as of the early 20th century local dishes began to figure on hotel and restaurant menus while, come the 1920s, Italian gradually entered the nomenclature of gastronomy (Capatti 1998, 2015).

The Guida gastronomica d'Italia published by the Touring Club Italiano is certainly the first systematic, complete classification based on a deliberate and explicit policy of linking food to place (Touring Club Italiano 1931). That project was launched in spring 1928 by the Milanese Rotary Club; it enjoyed the backing of Ugo Ojetti, a leading Fascist intellectual. ${ }^{2}$

The work was a novelty in the journalistic field and stands out from all previous works for its range of coverage and solid underlying research. It took several years to draw up, being the result of massive reconnaissance in the field, involving institutions, experts and the public at large. The guide's ethnographic ambition was to map popular cuisine by painstaking research at a local level. This began with a questionnaire targeting 5,000 "consuls" (under Fascism consuls were honorary colonels from the voluntary national militia), 1,800 doctors and 600 pharmacists. It went on to involve the National Fascist Confederation of Farmers and its many provincial branches, 92 provincial economic councils, 100 or so members of the Federation of Farmers' Cooperatives, numerous female 
provincial fasci, 400 podestà (Fascist mayors), 300 heads of teaching staff and 500 primary teachers. Then there were the experts: about 100 manufacturers of gastronomic specialities, hotel managers, chefs, restaurant managers and many Touring Club members who had learned of the project from the main touring magazines: Le vie d'Italia and L'Albergo in Italia.

The mass of feedback produced a rich picture of diet and food specialities across the peninsula, tens of thousands of pages for the editors to sift in compiling their first edition. For a later revision they went back to consulting the field: 700 draft versions were printed and circulated to the top local experts for their emendations and additions. The resulting volume was more than 500 pages in length and presented dishes from all Italian regions and most of the provinces (Capatti 2003; Portincasa 2008).

In his introduction to the work the agricultural under-secretary, Arturo Marescalchi, recalled an exhibition of Italian gastronomic specialities he had organized at Casale Monferrato early on in the century. Apart from his political role, Marescalchi could claim professional know-how. Born at Baricella near Bologna in 1869, he trained as a wine-maker at the celebrated Conegliano institute; he completed his education in France and then practised as a journalist. He founded and edited the periodical L'Italia vinicola e agraria, was the mainstay of wine-growing associations and became the president of the Association of Italian Wine-Makers and the National Fascist Federation for the Wine Trade. He entered the parliament with the liberals in 1919, went over to the Fascist and national ranks and remained in the parliament until 1934, when he was nominated as a senator of the kingdom. His two main works, published in the 1930s, are the Storia del vino e della vite in Italia (History of Wine and Vines in Italy), and Il volto agricolo dell'Italia (The Agricultural Face of Italy). The link between the farming landscape and the wine and food cultures was a central focus for Marescalchi, who became the guide's political godfather and personally checked and supervised the parts devoted to wine.

The guide's main purpose - to identify the tight link between place and food - is clearly argued in the introduction, which goes out of its way to assure the reader that classifying dishes by region and province in no way contradicts the national principle; indeed, it enhances it and displays its wealth. "Our aim here is merely to point out what foods and wines are special from an Italian regional, provincial and local viewpoint [...] the Guide in short enables and encourages one to appreciate Italian produce. And that is good work for the nation" (Touring Club Italiano 1931, 5).

Food bears witness to the cultural heritage enshrined in local natural features and in the anthropological traits of the inhabitants; the guide is a detailed vade mecum to the land of Italy:

as to how there may sometimes be visible connections with the type of inhabitants, their lifestyles and work patterns, and sometimes even with their religious beliefs or fund of legends. [...] [O]ne inevitably looks for 
affinities between the character of a people and the wine it prefers as its habitual refreshment. The wines of Piedmont may be hard, rough and austere, but they conceal firmness of purpose and virtuosity of "nose". Fine and subtle are the most famous wines of the Venetian hills. The wines of some parts of Emilia and Romagna are boisterous and expansive without any hidden snares.

(Touring Club Italiano 1931, 6)

Underlying these remarks is an "environmental determinism" that forms one of the cognitive hallmarks of the guide. The idea that the people's character is shaped by environment and climate had a long tradition, of course, coming down from Aristotle to the French and German Enlightenment, especially via Montesquieu. Although it acknowledged that many dishes could be consumed in various localities, the guide's objective was to pinpoint the places where there was a fundamental connection between food and locality: "If one is drawn to a speciality, one needs to know where the authentic, genuine, perfect form is to be had. This is what the Touring's painstaking work makes possible" (Touring Club Italiano 1931, 7).

The guide is regional and provincial, plotting the rich mosaic of Italy's gastronomic identity; it thus rules out "imported victuals and beverages - national or maybe cosmopolitan" (Touring Club Italiano 1931,11). The aim of the map is to classify gastronomy in Italy, stripped of its many links to cultural and commercial exchanges with broader areas which, at various points of history, provided the real context in which the local cultures actually formed.

The example Marescalchi chooses for an exclusive relationship between food and place could hardly have been more unfortunate. He advises "tasting the traditional couscous at Trapani". It is well known that the dish hails originally from sub-Saharan Africa and then spread to western Islamic regions. Trapanese fishermen imported it from the Maghrebian coast and adapted it to their own lifestyle, introducing a notable innovation: a fish condiment, not meat or vegetables as in Islamic couscous. The "Trapanese speciality" was just the kind of "cosmopolitan connection" that Marescalchi wished to avoid: it spanned the shores of two continents as well as the Muslim, the Christian and the Jewish worlds. Clearly the idea of a national food, based on regional variants, derived from an exclusive idea of the relationship between culture and locality: ethnocentric, in other words. For that bond to be tight, one had to deny all other connections crossing the nation and making it permeable, subject to constant change, nourished by encounters with outside from which innovations might occur and later become established.

When the topic of Trapanese cuisine comes to be analysed in greater detail later on in the core of the book, there is a fleeting allusion to the dish's unspecified "exotic origin", though that is secondary to its specific Trapanese form. The decisive Arab influence in Sicilian gastronomy is hushed up; the emphasis is on the "peculiar needs of the population in terms of the climate and the raw 
materials they use, reflected in the customs of the peoples that succeeded one another in the island over the centuries" (Touring Club Italiano 1931, 437). Once again appears the allusion to an outside factor that the book's underpinning methodology had excluded, in favour of the idea that food and cooking were indissolubly and exclusively embedded in the locality. Thus "the island's confectionery masterpiece", cassata, is presented as though no borrowing had occurred from outside encounters. The truth is that, though only codified in its current version at the end of the 19th century, cassata has nearly 1,000 years of history. Its roots lie in innovations imported by the Arabs to the island's food history: cane sugar, bitter oranges, lemon, lime and mandarin. Baked cassata, which need not be sweet, stemmed from this encounter between Arab ingredients and Sicilian sheep cheese. It later became fixed as a dessert when pan di Spagna (sponge cake) from the Spanish court arrived in Sicily - a long, fascinating, complex story which once again entails the mingling of histories and the crossing of borders.

When the guide deals with frontier zones, the rigid nationalist policy becomes especially evident. There is a chapter on "Tridentine Venetia" and one on Venezia Giulia. Here too are fleeting references to the influence of past "foreign occupations"; but while the German influence can be found in the upper Tridentine valleys with their "alien traits of Germanic origin", this is emphatically not the case further south "in those Trentine lands whose Italian and Venetian purity has held out, rock-like, against all attempts at absorption" (Touring Club Italiano 1931, 147).

In Piedmont too there is a marked attempt to distance the regional from French cuisine. The latter, it is pointed out with some asperity, is mistakenly over-present in 19th-century recipe books purporting to represent the region's cookery. In the guide's view this showed the influence of the French court over other European courts and the gastronomy of grand hotels and aristocratic families, including the city of Turin with its cosmopolitan elite. But the deeper Piedmontese provinces remained immune to such influences, so that we may conclude that "broadly speaking, the alleged influence of France on Piedmontese cooking does not exist” (Touring Club Italiano 1931, 16).

Two kinds of cuisine answer to completely different and even opposite casts of mind: "just as the one [French cuisine] goes in for the refinement of de-luxe complicated dishes, gratifying the eye before the palate, so Piedmontese cuisine keeps simple, tasty and clear-cut in its tastes, due in part to the delicious 'raw materials' it employs in its frank and undisguised concoctions" (Touring Club Italiano 1931, 16-17).

On closer inspection, however, precisely these "raw materials" point to France and a history of connections that hardly make Italy the kind of independent patchwork the guide would have us believe. Take bagna càda, for instance, which is certainly a popular course in the Piedmontese plain and one of the hallmarks of the area's gastronomy. An area cut off from the sea nonetheless made a dish based on anchovy sauce into its pièce de résistance. The 
paradox would be incomprehensible without our crossing over the Provencal border, where Piedmontese salt merchants travelled from the late Middle Ages on. There they came across anchoiade, which they refashioned for themselves, without capers, when they brought back salted anchovies over the high passes of the Maritime Alps.

So it was, again, with Livornese cooking, where the guide picks out caciucco (fish soup) for praise, the word being Turkish in origin. Other typical "Livornese" concoctions cited are mullet, which dates back to the Sephardi Jews who took the tomato to Spain. But as for the fact that the town's entire gastronomic culture stemmed from a history of marine and commercial exchanges, the guide keeps silent.

In short, it builds up an exclusive, static, ethnocentric link between the locality and its gastronomic culture. Precisely because it traces cuisine to the "spirit of the people", it adopts a vaguely polemical tone towards any elite, cosmopolitan or French-influenced style of cooking as being rootless and needlessly artificial - a polarity that is recurrent, but that is never properly developed so as not to stir up social and political connotations. In actual fact the guide does not target the lower classes, but a middle-class consumer who needs to be attracted into the provincial hostelries, restaurants and small hotels that the Touring Club and Enit (Ente nazionale italiano per il turismo) are urging to upgrade their image by drawing on the local cultural heritage.

It was felt that the more "authentic" folklore events were gradually dying out. This fuelled a revival of popular culture, which Fascism tried to turn into a drive for modernity (Cavazza 1997). One notes how some of the leading scholars of popular tradition were encouraged by Fascism, either because they were its creatures, like Giuseppe Cocchiara, or because they were active interlocutors like Paolo Toschi, who became the first incumbent of the chair of History of Popular Traditions founded at Rome in 1938.

In the touring magazine Le vie d'Italia we find many reports of popular festivities and a folklore-based photography competition showing local folk in traditional costume plying some ancient and now obsolete trade, or pictures of traditional events like La diavolata pasquale at Adrano. Every 1930 issue bore whole-page photos selected by this competition. At the same time the magazine L'albergo d'Italia plugged the link between regional food and traditions, and an infrastructure of hotels and restaurants bent on improving tourist standards in the provinces by avoiding imitation of cosmopolitan hospitality in the big international hotels.

\section{Italy as a brand: Galbani cheese}

The process of discovering the traditions, regions and food habits of the country got under way in the first decades of the century, and culminated in a regional classification of food culture that was not without foundation, but that was arbitrary in its rigid demarcation of frontiers and identity boundaries. The 1932 
guide devised a regional who's who of Italian gastronomic culture which postwar food guides would still refer to. But linking food to a locality could also be the result of simple marketing strategy, as in the case of Bel Paese cheese produced by the firm of Galbani.

At the time of national unification the Italian cheese industry was comprised of small firms serving local markets. The most advanced entrepreneurship was in Lombardy, where two main production areas existed: the mountainous part with its soft cheeses, stracchino and gorgonzola to the fore; the harder Po Valley varieties, the best known of which was grana.

Valsassina in Upper Lombardy had a tradition of seasonal cheese production linked to the herds pasturing in the Alps and the presence of caves suitable for seasoning. In the village of lower Ballabio Davide Galbani, a blacksmith by trade, started producing summer cheeses, and this effort was built up by his son Egidio. In the last decades of the 19th century the national railway grid extended and linked up with Europe through the railway tunnels of Fréjus (1871) and St Gotthard (1882). This completely changed the scale of markets and brought Italian companies opportunities for exportation, whilst allowing into Italy fierce competition from France and Switzerland, including soft French cheeses like Roquefort, Brie and Camembert.

Egidio Galbani knew how to profit by this market expansion and began widespread marketing of cheeses like taleggio and robiola. He built up his father's business and set up a factory in the plain at Melzo near the huge market of Milan and linked to the Milan-Venice railway. Galbani was a marketing innovator, identifying his wares as Italian. His first attempt was Robiola Italia, but undoubtedly his greatest success was Bel Paese cheese, which turned an existing symbolic heritage into a winning marketing campaign.

The name Bel Paese referred to a post-unification publishing bestseller whose author, Antonio Stoppani, had been a patriot, priest and geologist. He had taken part in the Risorgimento and taught geology at Milan University, as well as being an adventurous rock climber. From his deep knowledge and study of the Italian landscape he published many scientific works. His fame with the wider public was owed to an extremely successful work of divulgation, Il Bel Paese, first published in 1876 and already in its 41st edition by 1897. It continued to be published throughout the 20th century (Redondi 2013). It is one of the texts upon which national pedagogy was based, and set out to spread awareness of Italian natural beauty spots. It had an effective narrative structure, being composed of "30 evenings" on which "Uncle Antonio" told the family circle about the country's marvels of geology, geography and natural history. Stoppani had an audience of teachers in mind, and the book was indeed widely used in Italian schools.

Stoppani's face was well known to the public, being printed on all copies of the book. In 1906 Egidio Galbani decided to market a new type of cheese that he called Il Bel Paese. In this way he exploited that massive publishing success and introduced another basic innovation: on the wrapper he printed a recent 
map of the Italian railway network, highlighting the connections between Italy's many cities, including an imperial projection onto the Slavic shores of the Adriatic and a picture of the Abbé Stoppani. The combination became an icon in Italian food marketing.

Though Galbani's entrepreneurial story was linked to one particular area and its cheese-making tradition, he wisely prevented his produce from being identified with one locality; as an "Italian" product it could find its niche on the whole national market and be recognized abroad. It was a major and long-lasting marketing success. Between the two world wars the company exported 30$50 \%$ of its output, above all to France, Germany Britain, the United States and South America, sometimes in the wake of Italian communities (Farrar 1939).

In the 1950s the Galbani firm began to advertise its goods on television, following the same marketing policy it had embarked on 50 years before. Its television ads were titled "Tour of the Bel Paese", alluding to the Giro d'Italia cycle race, which had become immensely popular. They were a series of shorts featuring Italian cultural and historical heritage through the homes of great artists and writers. The compère, Mario Soldati, accompanied viewers on a cultural tour, visiting Massimo D’Azeglio's house at Cannero on Lake Maggiore, Francesco Petrarch's last house at Arquà near Padua, Torquato Tasso's at Gattinara and Giuseppe Parini's in Brianze.

The example of Bel Paese reminds us that a gastronomic product may be associated with a place by a marketing strategy without any specific tie-up between the food and the locality. The case in point was not "Italian", but from Valsassina; by way of a "supralocal" identity, it might have been claimed as a typical transnational Alpine cheese similar to others made in the French, Swiss and Austrian Alps under the names of Fleur des Alpes, Komgskäse or Schonland.

\section{From regional tradition to place-less nostalgia}

The regionalization of gastronomic identity that took place in the early decades of the 20th century in Italy was bound up with political and publishing schemes to modernize the country. Tradition and modernity went hand in hand, as it were: discovery of the provinces coincided with the possibility of getting to know and appreciate them thanks to modern means of transport, leisure time and culture. Revival and classification of regional culinary traditions did not clash with the development of a food industry; in fact, major names from that industry advertised in the touring guide: Perugina, Sperlari and Buitoni. Postwar Italy rapidly turned into an urban, industrial society. The people's eating habits were increasingly moulded by the food industry with its marketing strategies based on television advertising and widespread distribution on which food consumption hinged.

Against this background two major cultural products furthered the relationship of food and locality in the new 1950s media: a radio broadcast by Guido Piovene Viaggio in Italia (Travels round Italy) between 1953 and 1956, and 
Mario Soldati's television series Viaggio nella valle del Po (Tour of the Po Valley) in 1957 and 1958. While Piovene sketched a picture of the country poised before the economic boom in which cookery was recognized as a hallmark of regional variety, Soldati travelled down Italy's greatest waterway, revealing ageold local food traditions cheek by jowl with new industrial developments that revolutionized the country's feeding habits. Romantic glimpses of places off the beaten track where local specialities could be tasted at ancient trattorias blended happily with documentation of a developing food industry which did have the historical merit of solving the country's food problem. The two dimensions, gastronomic tradition and a future where the industrialization of food was forging ahead, could seemingly cohabit and complement one another.

It was in the 1970 s, when a completely industrialized Italy was riven by violent social and political conflict, that marketing strategies began to pump the past for nostalgic potential.

Johannes Hofer coined the term nostalgia in the 17th century to describe a psychosomatic complaint widespread among young Swiss far from home. Among the causes of this separation malaise Hofer mentioned dietary habits: "the dearth of good genuine milk that those brought up on it cannot readily do without" and "inability to adapt to foreign customs and diet" (Hofer 1688, 5, 6). Being uprooted from one's feeding habits caused physiological alterations and an ardent desire to be reunited with one's place of origin. In the course of the 19th century the heuristic value of nostalgia as a medical category began to wane, and it entered the realm of poetry with the full spate of European romanticism (Boym 2001; Starobinski 1992). In this transition nostalgia underwent a semantic shift: it came to depend less on space and more and more on time. Greater familiarity with distant lands and efficient rapid transport softened the pangs of spatial nostalgia, but that which depended on time gone by seemed incurable. Only poetry could soothe the suffering by evoking the lost past and conjuring it anew in language the fleeting emotion of which provided some relief. Nostalgia thus hankers for a restored enchantment, a feeling that kindles desire for a past that never existed, and is thus a powerful tool for the engineering of desire that has grown sophisticated in our postmodern era. ${ }^{3}$

While nostalgia now permeates our commercial culture, the peculiarity of nostalgia for the food of yesteryear is its purely discursive nature. Unlike the commercializing of vintage objects that pervades postmodern consumerism, the food consumed in the past cannot be recovered: one can only frame a picture of present food in an act of aesthetic communication alluding to the past by advertising, packaging and décor at consumer venues.

The most successful example of nostalgia being used commercially as a marketing ploy is certainly that of Mulino Bianco Barilla. At a time when Italy was going through deep social crisis, with violence escalating and breeding insecurity, Barilla launched a new product line hinging on "return to nature", traditional family values and the good country life of the old days. ${ }^{4}$ The storyline was purely fictitious, not just because Barilla was promoting an entirely industrial product, but because Italy's country outback had endured a history of 
poverty, toil and class conflict that had nothing of the rural idyll depicted in the Barilla advertisement. The nostalgia halo enveloping this publicity campaign tied the product's value to the past and cancelled the present-day industrial society whose dark side was beginning to be seen and feared. When the ad, based on a drawing of the mythical white mill, proved a huge success and consumers clamoured to visit it, the company purchased a dilapidated old farmhouse with an adjacent mill, did it up and created a real white mill in which it later shot publicity ads and organized visits by the public. The drawing of the past had become artifice, a counterfeit.

\section{Conclusion}

By using a purely invented past, Mulino Bianco Barilla achieved one of the greatest successes in the history of Italian publicity (Fasce, Bini and Gaudenzi 2016). This admittedly extreme instance shows how deeply contemporary food marketing has been affected by the nostalgic "turn". ${ }^{5}$ Such banalizing of the past needs to be combated in any recognition of food as a cultural heritage; we should mistrust plausible-sounding definitions of identity (Aime 2004) and highlight the plurality of resources and exchange of experience that have gone into the preparation of food in its social and cultural contexts. None of this restores a harmoniously consistent picture, but it does bring us closer to the cognitive potential of food as an expression of stories that may be complicated and tortuous.

\section{Notes}

1 The author, a doctor, writer and man of many parts, native of Nice but early transplanted to Genoa and later Emilia, had already published various papers showing his anthropological interest in food (Cougnet 1903, 1905).

2 The Italian Rotary Club involved many Milanese similar in social extraction to members of the Touring Club; on its ups and downs with Fascism, see Rambaldi 2006.

3 Jameson (1991) introduced the idea of nostalgia as an agent of de-historicization in postmodern culture (especially chap. 8: Nostalgia for the Present). Boym (2001) is critical of nostalgia for the present, which she sees as tribalism clinging to invented pasts, a position in turn contested by Cross (2015), who sees nostalgia mediated by consumer objects as a kind of individual re-appropriation of time or at least a defence against its consuming action. On the role of food nostalgia in coming to terms with subjective spatial dislocation see Swislocki (2008), Mannur (2007).

4 Market research into food has shown that the image of the happy family and its children is one of the most effective iconographic ways of arousing desire shot with nostalgia for consumption of a product (Vignolles and Pichno 2014, 225-38, especially 235).

5 Marketing studies have insisted that the use of nostalgia as the driving force in a relationship with goods exploits a dissociation of identity with respect to the present time; see J. Sierra and S. McQuitty (2007). One can still agree with Barbara B. Stern (1992), that this phenomenon is not confined to publicity, but permeates contemporary culture. 


\section{References}

100 specialità di cucina italiane ed estere (1908) Milan: Sonzogno.

Abad, R. (2002) Le Grand Marché. L'approvisionnement alimentaire de Paris sous l'Ancien régime, Paris: Fayard.

Agnetti,V. (1910) La nuova cucina delle specialità regionali. Piemontesi - Ligure - Lombarde Venete - Emiliane - Romagnole - Toscane - Romane - Napoletane - Siciliane e Sardegnole, Milan: Società Editoriale Milanese.

Aime, M. (2004) Eccessi di culture, Torino: Einaudi.

Asor Rosa, A. (1966) Scrittori e popolo, Rome: Samonà e Savelli.

Bardelli, D. (2004) L'Italia viaggia. Il Touring Club, la nazione e la modernità (1894-1927), Rome: Bulzoni.

Barth, H. (1908) Osteria. Kulturgeschichtlicher Führer durch Italiens Schenken von Verona bis Capri, Stuttgart: Julius Hoffmann Verlag.

Boym, S. (2001) The Future of Nostalgia, New York: Basic Books.

Capatti, A. (1998) Lingua, regioni e gastronomia dall'Unità alla seconda guerra mondiale, in A. Varni, A. De Bernardi and A. Capatti (eds), Storia d'Italia. Annali. 13. L' alimentazione Turin: Einaudi, 755-801.

Capatti, A. (2003) Il Buon Paese, Milan: Touring Club Italiano.

Capatti, A. (2015) "Scoperta e invenzione della cucina regionale", L'Italia e le sue regioni, vol. 4 Territori, Rome: Istituto dell'Enciclopedia italiana, 409-25.

Capatti, A. and Montanari, M. (1999) La cucina italiana. Storia di una cultura, Rome: Laterza.

Carnago, G. (1892) La vera cuciniera genovese: metodo facile e veloce per preparare e cuocere ogni vivanda all'uso di Genova, Genoa: Giovanni Prina Editore.

Cavazza, S. (1997) Piccole patrie. Feste popolari tra regione e nazione durante il fascismo, Bologna: Il Mulino.

Cougnet, A. (1903) I piaceri della tavola. Contributo alla storia della cucina e della mensa, Turin: Bocca.

Cougnet, A. (1905) Il ventre dei popoli. Saggi di cucine etniche e nazionali, Turin: Bocca.

Cougnet, A. (1910) L' arte cucinaria in Italia: trattato teorico, pratico e dimostrativo della cucina italiana e delle principali straniere, applicabile a qualsiasi servizio, sia per cucina di lusso che per quelle d'albergo e di famiglia, 2 vols. Milan: Wilmant.

Coveri, L. (2012) "Artusi e dintorni, Assaggi di lingua nelle Cuciniere regionali dopo l'Unità. Il caso ligure", in G. Frosini and M. Montanari (eds), Il secolo artusiano. Atti del convegno Firenze-Forlimpopoli 30 marzo - 2 aprile 2011, Florence: Academia della Crusca, 123-34.

Croce, B. (1929) “Poesia 'popolare' e poesia 'd'arte'. Considerazioni teorico-storiche”, La Critica. Rivista di Letteratura, Storia e Filosofia diretta da B. Croce, 27: 321-39.

Cross, G. (2015) Consumed Nostalgia: Memory in the Age of Fast Capitalism, New York: Columbia University Press.

Csergo, J. (2007) L'emergere delle cucine regionali: la Francia, in J.L. Flandrin and M. Montanari (eds), Storia dell'alimentazione, Rome: Laterza.

de la Varenne, F.P. (2001) Le cuisinier françois: d'après l'édition de 1651, ed. P. Hyman and M. Hyman, Orthez: Editions Manucius.

Farrar, R.R. (1939) A Soft Cheese of the Bel Paese Type, United States Department of Agriculture, Circular no. 522, April. 
Fasce, F., Bini, E. and Gaudenzi, B. (2016) Comprare per credere. La pubblicità in Italia dalla Belle Epoque a oggi, Rome: Carocci.

Hofer, J. (1688) Dissertatio medica de nostalgia, oder Heimwehe, Basileae.

Il cuoco milanese e la cuciniera piemontese: manuale di cucina indispensabile per ogni ceto di famiglia. (1859) Milan: Francesco Pagnoni.

Jameson, F. (1991) Postmodernism or the Cultural Logic of Late Capitalism, Durham, NC: Duke University Press.

La cuciniera bolognese (1990) Ossia Modo semplice e facile di cucinare ogni sorta di vivande e delle diverse salse tirate ad uso italiano, con la descrizione dei prodotti d'ogni genere nelle quattro stagioni dell'anno, Sala Bolognese: A. Forni (1874).

Legrand d'Aussy, P.J. (1782) Histoire de la vie privée des Français depuis l'origine de la nation jusqu'à nos jours, 3 vols. Paris.

Maestro Martino (2001) Libro de Arte Coquinaria, ed. L. Ballerini and J. Parzen, Milan: G. Tommasi.

Mannur, A. (2007) "Culinary nostalgia: authenticity, nationalism, and diaspora", Melus 4: $11-32$.

Meldini, P. (1997) L'emergere delle cucine regionali: l'Italia, in J.L. Flandrin and M. Montanari (eds), Storia dell'alimentazione Rome: Laterza, 658-64.

Montanari, M. (2014) La fame e l'abbondanza: storia dell'alimentazione in Europa, Rome: Laterza.

Palma, F. (1881) Il principe dei cuochi, o la vera cucina napolitana: operetta indispensabile ai capi di famiglia e agli esercenti il mestiere di cuoco ... compilata sulle opere del Corrado, del Cavalcanti ed altri, Naples: Eschena.

Pardo Bazán,E. (1913) La cocina española antigua, Madrid: Sociedad Anónima Renacimiento.

Parkhurst Ferguson, P. (2004) Accounting for Taste: The Triumph of French Cuisine, Chicago: University of Chicago Press.

Paz Moreno, M. (2006) "La cocina española antigua de Emilia Pardo Bazán. Dulce venganza e intencionalidad múltiple en un recetario ilustrado", La Tribuna: cuadernos de estudios da Casa Museo Emilia Pardo Bazán, 4: 243-51.

Pivato, S. (2006) Il Touring Club italiano, Bologna: Il Mulino.

Porciani, I. (1996) "Lokale Identität-nationale Identität. Die Konstruktion einer doppelten Zugehörigkeit", in O. Janz, P. Schiera and H. Siegrist (eds), Zentralismus und Föderalismus im 19. Und 20. Jahrhundert. Deutschland und Italien im Vergleich, Berlin: Duncker und Humblot, 103-33.

Portincasa, A. (2008) "Il Touring Club Italiano e la Guida Gastronomica d'Italia. Creazione, circolazione del modello e tracce della sua evoluzione (1931-1984)", Food \& History 1: 83-116.

Prete, A. (1992) Nostalgia. Storia di un sentimento, Milan: Cortina.

Puccini, S. (2005) L'itala gente dalle molte vite. Lamberto Loria e la Mostra di Etnografia italiana del 1911, Rome: Meltemi.

Raimondi, E. (1993) Un europeo di provincia: Renato Serra, Bologna: Il Mulino.

Rambaldi, E. (2006) Rotary International, a "Brotherhood of Leadership". Il caso italiano tra fascismo e primi passi della Repubblica, Rome: Carocci.

Ratto, G.B. (2004) La cuciniera genovese, ossia la vera maniera di cucinare alla genovese, Genoa: Fratelli Frilli.

Redondi, P. (ed.) (2013) Un best-seller per l'Italia unita. Il "Bel Paese" di Antonio Stoppani con documenti annessi, Milan: Guerini e Associati. 
Sierra, J. and McQuitty, S. (2007) “Attitudes and emotions as determinants of nostalgia purchaser: an application of social identity theory", Journal of Marketing Theory and Practice 15(2): 99-112.

Starobinski, J. (1992) "Il concetto di nostalgia", in A. Prete (ed.), Nostalgia. Storia di un sentimento, Milan: Cortina, 85-117.

Stern, B.B. (1992) "Historical and personal nostalgia in advertising text: the fin de siecle effect", Journal of Advertising 4: 11-22.

Storm, E. (2016) "The nationalisation of the domestic sphere", Nations and Nationalism 23(1): 173-93.

Swislocki, M. (2008) Culinary Nostalgia: Regional Food Culture and the Urban Experience in Shanghai, Stanford, CA: Stanford University Press.

Touring Club Italiano (1931) Guida gastronomica d'Italia, Milan: Mondaini.

Vignolles, A. and Pichno, P. (2014) "A taste of nostalgia. Links between nostalgia and food consumption”, Qualitative Marketing Research 3: 225-38. 


\title{
In the kitchens of ' 68
}

\section{The impact of student protest and counterculture on attitudes towards food}

\author{
Marica Tolomelli
}

\section{Overcoming barriers: the new cultural meaning of kitchens and dining rooms}

The student protests that culminated in 1968 aimed at subverting not only the rules and values of the bourgeois social order, but also the habits, manners and behavioural attitudes affecting social life both in the public and in the private sphere (Lazzarini 1980). Week-long occupations of universities were the ideal situation in which to experiment with the informal use of public spaces: classrooms were therefore transformed not only into reasoning and debating rooms; they also served as dining and sleeping quarters. Similarly, private spaces also became places in which to experiment with alternative forms of interpersonal relationships. In some cases, households lost their traditional function as oikos, a primordial place for intimacy, privacy and separation from public life, in favour of community lifestyles in which to translate into action some of the anti-institutional and anti-authoritarian issues behind the protests.

The kitchens, bedrooms and bathrooms of communitarian households became "spaces" where the bourgeois way of life could be challenged day by day. According to Alexandra Staub, the category of space is used here with reference to its cultural function as a modifier (Staub 2015). This means that the way in which space is used and the meaning ascribed to it always express cultural values. In the case of the communes founded by 1968 activists the shift of meaning given to traditionally private space was radical. Ordinary moments of private life such as breakfast, lunch or dinner; ordinary eating manners, like sitting properly at table, chewing and drinking silently, holding the correct posture; traditional gender roles connected with cooking, washing up etc., all these ordinary tasks of daily life were fundamentally challenged. It must be admitted that in some cases the reality of communitarian life was less revolutionary than intended; it was found particularly difficult to overcome the gender roles relating to reproductive tasks, but that is not to belittle the social relevance of the far-reaching goals pursued by the communes.

According to some theoretical assumptions of the transnational New Left, revolutionary practices were to be carried into every situation of daily life 
(Gilcher-Holtey 2008; Katsiaficas 1987). Domestic tasks were thus addressed and reinvented, moving from the assumption that all transformation of society must involve the transformation of each individual, of his/her daily habits and practices. This was the goal of nine West Berlin activists - among them Ulrich Enzensberger, Dagrun Enzensberger Kristensen, Dieter Kunzelmann, Rainer Langshans, Dorothea Ridder and Fritz Teufel - who in 1967 came up with the idea of moving in together, so as to begin immediately with concrete experimentation of their values in opposition to the prevailing social order (Enzensberger 2004). During the notorious life experiment of Kommune 1 (and later Kommune 2) in West Berlin - soon becoming a model for further such experiences in Western Europe - revolutionary aspirations were taken extremely seriously: doors separating rooms were removed and bedrooms and bathrooms were made accessible for all commune members without any restriction. The centre of communitarian life was the kitchen and dining rooms: they were the focus of the communards' daily lives as they ate and smoked around a table or lay on couches, carpets and mattresses. Even in less radical community experiments many features changed in the dining rooms of private households: not only manners and habits, but also food preferences and combinations and ways of cooking underwent new experimentation. New forms of conviviality went hand in hand with a growing open-mindedness about unknown foodstuffs and tastes. Wine consumption, unconventional combinations of ingredients, meals at unconventional times and low attention to hygiene thus became typical features of kitchens and dining rooms in urban communes. Sitting at table took on a profoundly new symbolic, political and cultural meaning, expressing a protest against the rigid conventions that reigned in the dining rooms of traditional families.

Besides political factors and a kind of wilful overthrowing of customs and traditions, the new awareness of unusual foods and recipes was partly prompted by young people's (especially students') growing freedom of movement across countries and even continents. Although student mobility only affected a tiny percentage of the affluent population, mass "motorization" and new migrant flows brought "gastronomic encounters", above all during the 1970s (Schneider 1973). That period, for example, saw a great increase in the number of young Greeks seeking work or study opportunities at Northern European universities, escaping from the colonels' repressive regime, while Portugal and Spain became more widely attractive as their transition to democracy proceeded and new expectations of change hung in the air. Europe also witnessed the arrival of political refugees from Latin America - Chile especially - seeking asylum from military dictatorships. To welcome and fraternize with such newcomers was natural for people sharing values and political stances. In some cases this led to forms of egalitarian community sharing, where daily life was, of course, punctuated by mealtimes, often resulting in the "cultural exchange" of cooking traditions. There again, criticism of a world that needed challenging translated into open-minded acceptance of basic differences, together with appreciation 
for authentic-looking traditions linked to nature and the soil rather than to social hierarchy.

As the 1960s merged into the 1970s, the experience of community living not only spread through the more marginal urban settings, but tended to diversify more, according to cultural inclinations and the values and goals upon which they rested. Marked differences thus emerged between urban and country communes (Moberg 1979, 285-7). While urban communes were preeminently concerned with the symbolic subversion of bourgeois values on one hand, and the organization of protest and other political activities on the other, rural communes were more sensitive to issues concerning a fundamental opposition to industrial civilization, the dominant model of social life, in favour of a new approach to nature and the environment.

There were obviously numerous reasons why many 1968 activists, come the early 1970s, went on to set up communes away from the town. It may have been in response to the need to drop out of urban living for political - evading problems with justice - or more strictly existential reasons, but whatever the cause, settling in the countryside entailed a radical change of lifestyle. In countryside communes providing food was an elementary matter that couldn't be ignored in daily life. What food and how to get it was a simple but unavoidable issue. More than in urban communes, where it was not necessary to cook while one could eat in restaurants, cafés or on the street, rural communes became the main place where cultural and political issues relating to food production and consumption were critically questioned and reformulated.

Direct contact with nature meant a world less contaminated by environmental alienation as engendered by industrial society; it encouraged sensitivity and attention to the quality of "intact" food, which is to say not impoverished or transformed by industrial processing. In the United States, where the growth of the food industry and the dire effects of industrializing agricultural output had a much longer history than in Europe, authoritative and well-substantiated voices of protest had been heard since the early 1960s. A classic in this sense was Rachel Carson's Silent Spring, 1962, in which the biologist published the results of her research into the impact of weedkiller and pesticides, especially DDT, on the food chain of "affluent societies". The study would become an out-and-out bestseller (Wöbse 2018). The rise of a new interest in producing and consuming foodstuffs outside the industrial circuits was noted, significantly, from the mid-1960s on, when the new concepts of organic food and organic farming were rediscovered and taken up by the hippie culture and particularly rural communes. Emblematically, the magazine Organic Gardening \& Farming rocketed to success at the end of the 1960s: it had made only marginal impact since it was launched in the 1940s, but was "discovered" by the rural communes who faced the hands-on challenge of meeting their daily food requirement without resorting to the major marketing chains. Among communes offering an alternative to urban and industrial living, the idea of "organic" soon came to 
symbolize a whole new lifestyle, based on the search for harmony with nature and the environment: "Living organically meant experiencing basic processes of growth, change and renewal. Embracing enduring life processes such as natural childbirth, breastfeeding, bread baking, and gardening, the organically inclined saw nature as an ally rather than as a nuisance or conquest" (Belasco 2007, 69).

While in the United States a new approach to country life, agriculture and the environment reached the proportions of a major turning point, following upon a now ascertained rift between the dominant lifestyle and the natural environment, Western Europe too witnessed a growing number of community experiments in more or less remote areas; as a result, once again interpersonal relations needed reorganizing to match the reconfiguration of man's relation to nature. From the many German Landkommunen (Reichardt 2014) to the French communes (Lacroix 1981), down to the lesser known but no less significant or radical community experiments in Italy (Lazzarini 1980), there was a marked increase in schemes answering the need for a new relationship with nature. The commune of Longo Maï, a political farm set up in 1972 at Limans in the Alps of Haute-Provence by former French 1968-ites liaising with the Austrian political group Spartakus and the Swiss group Hydra, was too radical an experiment to be typical of the average 1970s rural commune. But it is significant for the political spirit that ran throughout its long existence. The farm stemmed from the poorest of beginnings: reconstruction of a ruined farmstead on unproductive land denuded of its trees and in an inaccessible situation. It expressed the still ardent ideals of a group of French, Swiss and Austrian activists bent on creating a micro counter-society, not isolated from the rest of the world, but deeply committed to social causes and international solidarity (Willette 1993).

Whatever the aspirations from which each community sprang, all these new experiments in group living alternative to the traditional family model in their own way questioned the political and social relevance of food. Like a leitmotiv, a new awareness developed of the political, social and environmental implications linked to the production and consumption of food. The result of this was a growing sensitivity to organic food and an aversion to all forms of pre-cooking, adulteration and depletion of nutritional value.

The political and cultural sides to food, the scope for expressing one's own view of the world and acting to bring about change through food among other things, in keeping with the 1968 ideal of revolutionizing the whole of daily life, are well expressed in the words of a Californian communard:

We want to eat food that has the things our bodies need to grow, food that hasn't had all the goodness processed out of it, food in its proper season. And we'd like to eat food that has been grown and picked and cooked with love, by people who enjoyed what they were doing, food with good vibes in it. We want to stand in a good relation to the soil - to feed it well, so we 
will be fed by it. We're not fanatical about any of these things, but that's the general shape of what we want, and we think it's possible to have it.

(Sundancer 1973, 134)

But if the communes were the quintessence of theory, experiment and a new approach to food, they were by no means unique. Freshness, simplicity, harmony with nature, an ambition to feel part of a natural environment that science had shown to be vulnerable by publications such as Rachel Carson's study or the report on the Limits to Growth promoted by the Club of Rome ten years later (1972), were values that had entered the public domain and reached social milieus that were politically less go-ahead.

\section{The "long march across the institutions" reaches high gastronomy}

As already mentioned, "bourgeois" cooking and eating habits as well were affected by the subverting spirit of 1968. Typical or traditional dishes were rejected in favour of "popular", ethnic but also "political" food and different ways of cooking it. While traditional middle-class courses tended to be synonymous with bourgeois values, typical worker dishes attracted the gastronomic inclinations of the young intelligentsia. A few years later, a nouvelle cuisine movement in France seemed to be conveying some of the subversive outburst of 1968 into the field of high gastronomy. It was not the first time in the history of French gastronomie that culinary traditions had been profoundly challenged, but it was not by chance that the rise of unconventional cooking styles took place in the wake of 1968.

Although nouvelle cuisine was not an immediate outcome of student protest, some significant analogies can be detected. Public restauration spaces underwent some important changes due to the impact of protest on lifestyles, values and visions. In France, the questioning of bourgeois traditions, the subversion of hierarchies and the pursuit of creativity encouraged some chefs to combine ingredients with more daring experimentation and creativity. Building upon a frame of general social questioning, the shift to culinary transgression was quite natural: combining traditional cooking techniques with new ingredients or using old cooking techniques with old ingredients in illegitimate ways testified to a growing bent for transgression that would affect the hierarchical structures of haute cuisine. Mixing meat and fish, preparing salads containing vegetables and foie gras and mixing pot au feu with fish was a great way to subvert gastronomic conventions. The nouvelle cuisine movement arose in opposition to classical cuisine as embodied in Auguste Escoffier, the maître of French postrevolutionary and post-restoration haute cuisine, who achieved international recognition at the beginning of the 20 th century.

While the culinary rhetoric of classical cuisine drew on conservatism and conservation - often, dishes were named after places, noblemen or mythological 
characters associated with them - the great breakthrough of May 1968 created a radically new cultural atmosphere. Private suddenly became political and the scope of protest expanded until it even challenged classical cuisine, a synonym for the opposite way of life. Nouvelle cuisine was thus inspired by the Zeitgeist of change and radical questioning, but it was led by insiders, award-winning chefs, with more credentials and expertise than outsiders. In contrast to the social conflict on the streets, gastronomic activists drew on the professional resources gained in the field of French high gastronomy (Rao, Monin and Durand 2003). Nevertheless, one can argue that the culinary movement nouvelle cuisine developed as a kind of gastronomic vanguard, challenging the dominant symbols and structures of the sector in favour of individual freedom, spontaneity, creativity and virtuosity. While chefs in traditional restaurants lacked the freedom to create and invent dishes, the nouvelle cuisine movement made chefs into inventors, innovators and creators rather than mere technicians. In their way, nouvelle cuisine chefs were a field-specific conceptualist avant-garde that met a growing customer receptiveness to "the shock of the new" at table (Ferguson and Zukin 1998).

\section{Nouvelle versus authentic cuisine: a new approach to the heritage of food}

In the United States, particularly in Berkeley, California, one of the most influential university epicentres of the student movement, former hippie and civil rights activists critical of the lifestyle of industrial civilization tried to establish a new relation to nature by founding restaurants in keeping with the values of the movement. One paradigmatic example is the renowned Chez Panisse restaurant at Berkeley, opened in 1971 by activist Alice Waters. The biography of this woman is particularly significant because of the convergence of two different experiences that she managed to embody (McNamee 2009; Waters, Mueller and Carrau 2017). The first significant experience in Waters' life was her encounter with traditional French cuisine. During a study year in France in 1965, she got to know and appreciate eating habits, tastes and food she had never met in the United States. French people ate mostly unprocessed food and used local products like fresh vegetables and fruit, meat and fish from regional farms and so on. Once back in California, she found that the free speech movement and the civil rights movements had already evolved into a widespread counterculture affecting broad social sectors far beyond the academic field. The revolutionary atmosphere she found at Berkeley changed her life definitively. There she met not only charismatic activists like Mario Savio, whose oratory impressed her as much as the numerous bottles of wine he set on his table, but many other people who spread the feeling in everyday life that everyone could participate in changing the world. Soon she combined that feeling, the spirit of the movement, with her previous experience in France and came up with the idea of creating a place where people 
could gather to discuss, eating "real", good and well-served food. In opening Chez Panisse Alice Waters intended to do things differently and to reach out to like-minded people (Andrews 2008, 12-14). The principles driving her undertaking were clearly embedded in the counterculture values circulating and already experimented with within the commune scene: a) use of simple, fresh ingredients; b) attention to the quality of food; and c) awareness of social aspects concerning the ways food is produced and consumed. In other words, at Chez Panisse one was intended to feel the same climate of conviviality one could enjoy living in a commune: openness and pleasure at eating good food in a collective frame, and conversing about all possible issues. This was Alice Waters' main goal. As Andrew Smith noted, with "Chez Panisse, Waters hoped to create a place where her friends could discuss politics and enjoy good food. [...] Her true talent seemed to lie in selecting good chefs, cooks, bartenders, and waiters, and one of the people she hired early on was Jeremiah Tower" (Smith 2009, 258). This last had no experience in restaurant catering, but he loved cooking and good food, and he had read David's French Provincial Cooking and imbibed the principles of culinary philosophy.

To begin with, the enterprising activist tried to replicate good French cooking; but when Alice Waters realized that the flavour of the ingredients is conditioned by the soil, air and water of the places where they are grown, she set about hunting for the prime flavours of Californian agriculture. The land, with its biodiversity and the special features that each site offers, came to occupy pride of place over the original model of French culinary tradition (seen as the opposite of the industrialized US food output).

Particularly in the years when Jeremiah Tower was her head chef (1973-6), the simple message Waters sent out not only pioneered the organic health food movement, but was also ground-breaking with regard to questions related to what some years later would be debated in terms of sustainability. It was anything but common when in October 1976 chef Jeremiah Tower created a menu composed solely of local foods from the San Francisco Bay Area (Tower 2003, 111). At that time, no one paid much attention to the menu, but 25 years later food critics would hail it as one of the great turning points in American gastronomy. According to Thomas McNamee $(2009,6)$, Waters even "transformed the way Americans eat and the way they think about food".

Chez Panisse is especially significant in that it unites some of the virtuous effects of values and experience (political, cultural and gastronomic) circulating, meeting up and interacting across the Atlantic. In the cultural climate of protest and rejection of tradition, the weight of European culinary tradition by no means devoid of experimentation - one thinks of the French influence behind American chef Julia Child and her great culinary success back in the late 1950s (Fitch 1997; Smith 2009) - impacting the United States' now widespread industrialized food model led to a rediscovery of the value and meaning of food that ushered in some unexpected developments. However, Alice Waters is but one case - though outstanding - in a whole climate of "reshaping social 
behaviour" in the late 1960s, especially on the part of the younger generation. In that process conviviality was of basic importance. To meet and discuss politics or to organize events when seated in front of fine wine and good food went beyond the Californian counterculture. Just as pubs had become venues of proletarian socializing in Europe at the turn of the 20th century, so the late 1960s witnessed a rediscovery or creation of new countercultural venues of sociability where the quest for more authentic relationships could be pursued - including that with food.

In Italy, the osterie - simple, usually family-run venues serving plain, cheap fare based on fresh, genuine produce - became the preferred kind of popular gastronomic centres to meet in. Later on, in the 1970s, some of them became extremely successful and widely known places with an increasingly selected clientele sharing political and cultural values. Well known, for instance are the osterie Il Cibreo in Florence or the Osteria delle Logge in Siena, but the list could be endless. In West Germany Kneipen and Biergärten had the equivalent social function to the osterie in Italy, pubs in Britain or bistros in France. The only difference was that in Germany beer, local or not, remained the most popular drink, while wine would only be "discovered" and appreciated for mass consumption some decades later.

\section{Resist fast life by slowing the food: the long-lasting vision of ' 68}

In November 1987, i.e. almost 20 years after the rise of counterculture movements, civil rights and anti-systemic protest in the Western world, the first version of the slow food movement manifesto was published in Italy. As a manifesto, it was a short, point-by-point document taking a clear stance in relation to food. It voiced a critique of the way of life driven by the growth of capitalism and industrial civilization. It challenged the way in which Western eating habits had been shaped by the increasing spread of "fast food":

Born and nurtured under the sign of Industrialization, this century first invented the machine and then modelled its lifestyle after it. Speed became our shackles. We fell prey to the same virus: "the fast life" that fractures our customs and assails us even in our own homes, forcing us to ingest "fast-food". [...] Let us defend ourselves against the universal madness of "the fast life" with tranquil material pleasure. Against those [...] who confuse efficiency with frenzy, we propose the vaccine of an adequate portion of sensual gourmandise pleasures, to be taken with slow and prolonged enjoyment. Appropriately, we will start in the kitchen, with Slow Food. To escape the tediousness of "fast-food", let us rediscover the rich varieties and aromas of local cuisines. In the name of productivity, the "fast life" has 
changed our lifestyle and now threatens our environment and our land (and city) scapes. Slow Food is the alternative, the avant-garde's riposte.

(http://slowfood.com/filemanager/Convivium\%20Leader\%20Area/

Manifesto_ENG.pdf)

The author of the document was Folco Portinari, a novelist and, more important, a friend of Carlo Petrini, one of the most active figures in the field of cultural and political engagement for which food reflected the values of the social movements of 1968 .

The statement first appeared in the wine and food insert Gambero Rosso of the daily Il Manifesto, a communist newspaper founded in 1969 after a split within the Italian Communist Party. At that time Il Manifesto was a quite influential opinion maker within the Italian press, though it represented a minority stance within the Italian left and an even smaller voice within the Italian public sphere. There and then the ideas conveyed by the document found little echo and their impact was quite limited, but they would gain much higher resonance two years later. In December 1989 Slow Food Manifesto - International Movement for the Defence of and the Right to Pleasure was presented in Paris at the first international Slow Food Congress. The Parisian event gave the cue for international diffusion of the core ideas expressed by the manifesto.

As a document it became the foundation on which a transnational movement has unfolded down to recent times. In its very essence the manifesto tried to translate into theory a vision of life bound up with the emerging phenomenon of eco-gastronomy. The growing awareness of the ties between ecology and gastronomy grew out of a new and more sensitive attitude to the complex interrelations between the food produced, processed and consumed in wealthy and poor countries of the world and its ecological impact on the environment and sustainability. Eco-gastronomy became particularly appealing at the beginning of the 21st century, when it became evident that "the global economic system $[\ldots]$ is incapable of producing safe, culturally appropriate, tasty, quality food. And it is incapable of producing enough food for all because it is wasteful of land, water, energy" (Shiva 2005, quoted by Andrews 2008, 68). While the slow food movement addressed precisely these kind of matters relating to ecogastronomy, its life was much longer than a classical social movement. It evolved into an organized association "coordinated by an International Council and steered by an Executive Committee. The Executive Committee is the highest institutional governing body, with all appointments held for a four-year term. Carlo Petrini, who founded the movement in the 1980s, is the President of Slow Food" (www.slowfood.com/about-us/our-structure/) (accessed 23 January 2018).

In accordance with the food philosophy promoted by Slow Food - good, clean and fair quality - the role of the gastronome in society has evolved into a "modern gastronome" uniting the two principles of pleasure and ecological 


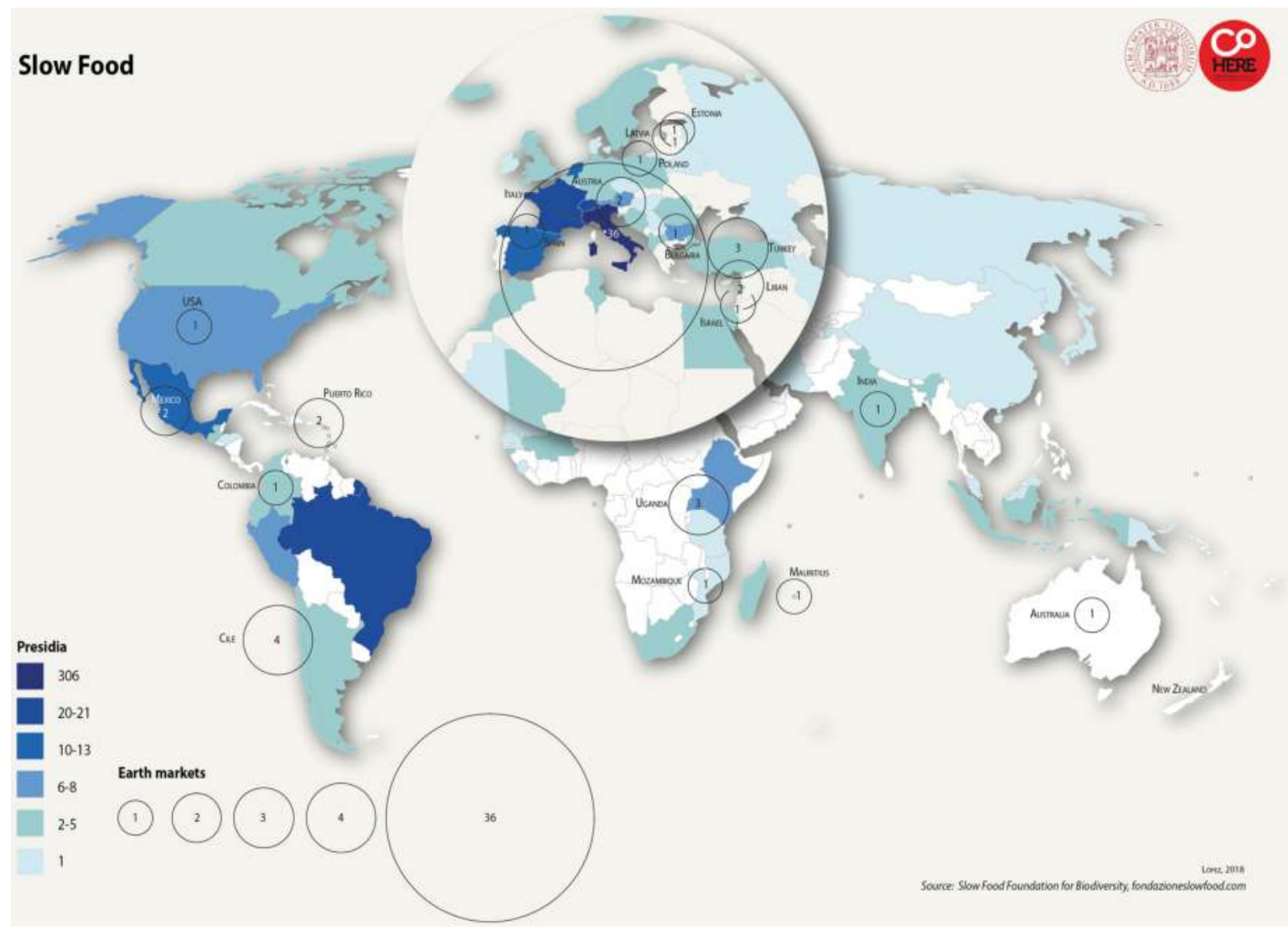

Figure 5.I Slow Food presidia and earth markets 
conscience in one and the same figure. In other words, at the end of this chapter we can state that some of the effects spawned by the social protest of 1968 can be verified in the replacement of the traditional gastronome by the ecogastronome, i.e. "someone who will have a cultural awareness, and a global perspective, as well as be capable of a fine sensory analysis" (Andrews 2008, 68). Thanks to his/her "finely tuned sense of taste" and his/her huge knowledge of food production, the eco-gastronome has become someone who plays a pivotal role in orienting and making understandable critical issues concerning the ecological and global economic context of food (as related to Italy, see Siniscalchi 2014).

The problem with this happy story is the relatively small clout that Slow Food carries. By promoting a different system of production and consumption parallel to the dominant one, it makes a promise containing the seeds of a better global system, but on the other hand it dares not actually face up to the reasons for the success of "fast-food". Supplying good, clean and fair food to a population growing at a speed out of all control remains one of the main problems on the fringe of slow food activism. The revolutionary élan of the "years of hope" (Gitlin 1987) seems therefore to have been lost in favour of greater sensitivity for the taste of food.

Yet some continuity with the spirit of '68 can be observed. As Geoff Andrews has put it, "while the food [Slow Food] favours is authentic, derived from long traditional knowledge and free of artificial chemical and influences, Slow Food's ideological menu is distinctly nouvelle cuisine, a mix of previously incompatible ingredients. They have made digestible a set of ideas that previously had little appeal to the political palate, enabling the power of 'old idea' to live in new settings" (Andrews 2008, 71).

The "old idea" Andrews mentions refers inter alia to the concept of politics whereby it is no longer possible to distinguish between private and public "spaces", as since the late 1960s they have been subverted and irreversibly merged.

The strongest link with the earlier era was the groundbreaking idea that "the personal is political." This found many expressions in sexual politics and the civil rights movement but was also fundamental to the way in which food has become a political issue. According to food writer Michael Pollan, food has become one of the means [by] which people make personal political choices. The personal dimension to food is "what people are responding to today", whether as activists in alternative consumption movements or just acting as informed citizens, they are making personal choices about the food they eat which often go against received opinion or the power of big corporations. 


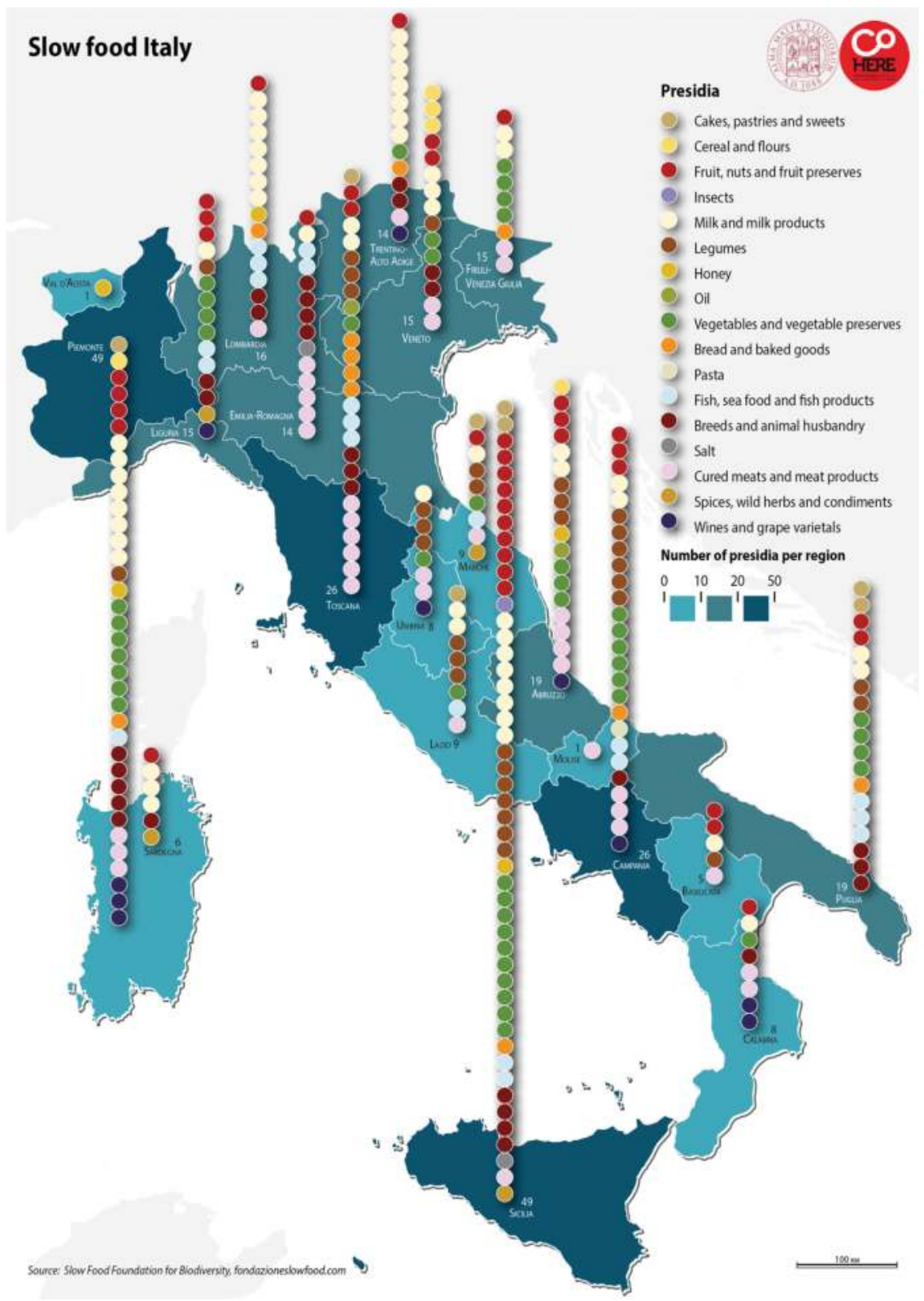

Figure 5.2 Slow Food Italy 
Agreeing with Andrews, Pollan also believes that the 1960s were formative in the development of the slow food movement in the United States. To that end he points to several continuities: the back-to-the-land movement, the hippie communes, Woodstock and the Diggers, which all had strong roots in rediscovering rural ways of living and "building a new society". "The contemporary politics of food thus has deep roots in the counter-culture" (Pollan 2009).

\section{Conclusion}

The transformative power of the 1968 movement, its determination to subvert not so much - or not only - class relations structuring the social order as all aspects of living - doing away with traditional limits of space, abolishing alleged separations between public and private, private and political, oikos and polis - started out from major revolutionary ideals and permeated the most elementary acts of daily life. The movement thus involved and reshaped food in its economic and commercial dimensions, productive regimens and organoleptic properties - not to mention its social, cultural and political sides. In the heyday of protest the venues and modes of food consumption were central to that transformation; during the long aftermath of the movement food became an object around which to propose new experiences of living or political-social engagement furthering values and aspirations that had survived from the high phase of protest: the community idea, the wish for shared spaces for conviviality, the ongoing quest for alternative forms of cohabitation besides the asphyxiating model of the nuclear family. We also see a growing attention to modes of producing and processing foodstuffs, a predilection for fresh food without additives or chemical agents. A new movement has formed, no longer based on ongoing mobilization, but on a new and daily renewed cultural attitude, in the hope that a radical change will come about in the relationship between human beings and nature, food and the land.

The trajectory of such developments has obviously not been linear or crowned with any marked success. New forms of social inequality have emerged, neutralizing the original transformative vision of projects like Longo-Maï or Chez Panisse. The less affluent social classes know all about eco-sustainable food, but are forced to resort to the mainstream marketing system to meet a dietary requirement that they cannot otherwise afford. In the 1980s the slow food movement emerged in opposition to a lifestyle geared to the success of fast food; in these early years of the 21st century the enemies are on the increase, with the invasion of "junk food" beating all competition while the commercializing of a slow food that is more exclusive than accessible makes it unlikely that sustainable agriculture will have any chance of being competitive. Luckily, at the dawn of the 1970s none of this was foreseeable. 


\section{References}

Andrews, G. (2008) The Slow Food Story. Politics and Pleasure, Montreal and KingstonIthaca, NY: McGill-Queen's University Press.

Belasco, W. (2007) Appetite for Change: How the Counterculture Took on the Food Industry, 2nd updated edn. Ithaca, NY-London: Cornell University Press.

Enzensberger, U. (2004) Die Jahre der Kommune 1. Berlin 1967-1969, Cologne: Kiepenheuer und Witsch.

Ferguson, P. and Zukin, S. (1998) "The career of chefs," in R. Scapp and B. Seitz (eds), Eating Culture, New York: State University of New York Press, 92-111.

Fitch, N.R (1997) Appetite for Life: The Biography of Julia Child, New York: Doubleday. Gilcher-Holtey, I. (2008) Kritische Theorie und Neue Linke, in I. Gilcher-Holtey (ed.), 1968. Vom Ereignis zum Mythos, Frankfort M.: Suhrkamp, 223-48.

Gitlin, T. (1987) The Sixties: Years of Hope, Days of Rage, New York: Bantam Books.

Hayes-Conroy, A. and Martin, D.G. (2010) "Mobilising bodies: visceral identification in the slow food movement", Transactions of the Institute of British Geographers, New Series 35(2): 269-81.

Katsiaficas, G.N. (1987) The Imagination of the New Left: A Global Analysis of 1968, Boston: South End Press.

Lacroix, B. (1981) L'utopie communitaire. Histoire sociale d'une révolte, Paris: Presses Universitaires de France.

Lazzarini, G. (1980) Le comuni tra pubblico e privato, in G. Campanini and P. Donati (eds), Le comuni familiari tra pubblico e privato, Milan: Franco Angeli, 116-24.

McNamee, T. (2009) Alice Waters and Chez Panisse: The Romantic, Impractical, Often Eccentric, Ultimately Brilliant Making of a Food Revolution, New York: Penguin.

Moberg, D. (1979) Experimenting with the Future: Alternative Institutions and American Socialism, in J. Case and R.C.Taylor (eds), Co-ops, Communes, and Collectives: Experiments in Social Change in the 1960s and 1970s, New York: Pantheon Books, 285-7.

Parasecoli, F. (2017) Knowing Where It Comes From: Labelling Traditional Food to Compete in a Global Market, Iowa City: University of Iowa Press.

Pollan, M. (2009) In Defense of Food: The Myth of Nutrition and the Pleasure of Eating: An Eater's Manifesto, New York: Penguin.

Reichardt, S. (2014) Authentizität und Gemeinschaft. Linksalternatives Leben in den siebziger und frühen achtziger Jahren, Berlin: Suhrkamp.

Rao, H., Monin, P. and Durand, R. (2003) "Institutional change in Toque Ville: nouvelle cuisine as an identity movement in French gastronomy", American Journal of Sociology 108(4): 795-843.

Schibel, K.-L. (2008) Kommunenbewegung, in R. Roth and D. Rucht (eds), Die sozialen Bewegungen in Deutschland seit 1945. Ein Handbuch, Frankfurt: Campus, 527-40.

Schneider, P. (1973) Lenz, West Berlin: Rotbuch Verlag.

Shiva, V. (2005), "Celebrating food economies". Resurgence 229. www.resurgence.org/ magazine/issue229-the-spiritual-imperative-html. (accessed 27 December, 2018)

Siniscalchi, V. (2014) "La politique dans l'assiette. Restaurants et restaurateurs dans le mouvement Slow Food en Italie", Ethnologie française 44(1): 73-83. 
Smith, A.F. (2009) Eating History: 30 Turning Points in the Making of American Cuisine, New York: Columbia University Press.Sundancer, E. (1973) Selery Wine: Story of a Country Commune, Ohio: Yellow Spring.

Staub, A. (2015) Conflicted Identities: Housing and the Politics of Cultural Representation, London: Routledge.

Tower, J. (2003) California Dish: What I Saw (and Cooked) at the American Culinary Revolution, New York: Free Press.

Waters, A., Mueller, Ch. and Carrau, B. (2017) Coming to My Senses. The Making of a Counterculture Cook, New York: Clarkson Potter.

Willette, L. (1993), Longo Maï. Vingt ans d'utopie communautaire, Paris: Syros.

Wöbse, A.-K. (2018), “Un bene naturale globale, ossia l'inizio di un'intesa ecologica tra i popoli”, Ricerche di Storia Politica 21(1): 35-50. 


\title{
A place at the table? \\ Food in museums as an "Ersatz politics" of difficulty
}

\author{
Susannah Eckersley
}

\section{Introduction}

This chapter explores three political uses of food and cuisine in museums and discusses the paradoxical relations between them. ${ }^{1}$ In each case food is a kind of proxy for politically based desires connected to difficult histories, as well as an indicator of different forms of nostalgic remembering and reimagining using a phenomenological approach (Farrar 2011). The first of these desires is for a "happy multiculturalism" in a present shaped by difficult issues of migration; the second is for a return to a mythic past of "how things were" prior to the perceived problems of the present day; the third is for public understanding of difficult times from the past and mourning for futures that never were. In each one, food is used as a means to argue for the significance of having, or in order to offer a "place at the table", where the politics of difficult issues can be revealed or hidden through the media of food or culinary objects. Holtzman (2006) analyses the deep connection between food and memory on multiple levels, and shows how it can be used for multiple purposes when addressing themes of ethnic and diaspora identity, sensuous memory, invented traditions and nostalgias, gender and agency, transformation through time and processes of remembering and forgetting. Indeed, despite the fact that Holtzman does not address museums in his article, the museum might be the ideal location within which to analyse all of these themes.

As this chapter shows, museums can use food to prompt, play on or touch on some kind of desire about the sociocultural order. Its everyday, appealing nature can enable the articulation of social values, culture, demographics and identity in a way that is subtle yet simple, so that visitors may understand complex or otherwise "difficult" political issues in recognizable and emotive form. The three issues examined in this chapter each respond to or play on a sense of nostalgia (Arnold-de Simine 2013, 54-67; Boym 2001), differentiated in each case according to the underlying political perspective of the museum. This could be the presumed nostalgic longing of migrants for a home far away or their processes of making new homes, epitomized by the sharing and exchange of food, its preparation and its consumption. Or it might be the overtly nostalgic 
remembering of bygone times as idealized places and moments (Farrar 2011) to which food and the senses might return us. Both of these forms of nostalgic remembering relate to notions of fabricated or reproduced authenticities within "a nostalgia for the past that is blind in some ways to structural inequities and forms of difference" (Mannur 2007, 15). Or it could be the difficult memories of food hardship and suffering, where nostalgia may be brought in as an oppositional device to draw attention to what (and who) existed before the hardship, and the unjust conditions of hardship.

Fieldwork for this chapter was conducted at museums around Europe between 2016 and 2018, as part of the European Commission Horizon 2020funded CoHERE project. This chapter analyses museums both in depth and in breadth - with key museums acting as primary field sites for in-depth analysis of specific issues, combined with insights from a broad survey of museums across Europe. The museums included in this analysis cover a variety of locations across Europe as well as a range of museum "types", including historical museums, ethnographic museums, open-air museums, a food museum, a city museum, a migration museum and a Holocaust museum. This plurality is indicative of the somewhat hidden or incidental nature of food in most museums, where it is usually simultaneously not a specific focus of the museum, and yet also an intrinsic part of it. Only very few "food museums" exist, and yet as both an essential element of human existence and a constituent part of much of our social, cultural, political and economic lives, food might seem to be an ideal medium through which to address multiple and often difficult histories. This is comparative with the ways in which other thematic issues, such as migration, are addressed in and by museums of varying types and in different places. The methodology used in this chapter therefore follows the approach taken by the author during previous work on migration in European museums (Whitehead, Eckersley and Mason 2012), which enabled a balance of broad and deep analysis of case studies, where each museum site was inevitably unique as a result of the varying histories, contexts, collections, audiences and sociopolitical and cultural conditions within which each museum operates. In this way, the approach to food in museums taken by this chapter addresses some of the concerns raised by Sutton in his review of food and the senses, in that it is crucial to focus on "everyday life and the multiple contexts in which the culturally shaped sensory properties and sensory experiences of food are invested with meaning, emotion, memory and value" (Sutton 2010, 220).

While food itself is not easy to put on display or to add to a collection, nevertheless from the wide range of museums visited and analysed for this chapter it is clear that many museums use common strategies to focus attention around food, its preparation and its enjoyment - often as part of an engagement with or subjugation of the politics of social difference and difficult histories. Museum displays and objects relating to food - its preparation, its consumption and its absence - were analysed using display analysis techniques from museum studies (Whitehead 2016a, 2016b). Museum activities and events relating specifically 
to food were researched online from museum websites and through semistructured interviews with three museum staff members. Due to the "objectpoor" nature of many difficult histories (Arnold-de Simine 2013, 10), and the inherent challenge of displaying actual foodstuffs in museums, the analysis covers a mixture of food-related objects, such as utensils, packaging, recipes and their presentation in museum displays and on online media platforms used by museums, as well as events connected with preparing, eating, cooking and sharing food. Food-focused events, whether festivals where food can be bought and eaten, demonstrations where visitors watch, learn and sample foods, or cookery classes where participants learn different, new - or old - recipes and share the results feature in many museum activities. Recipe books themselves can be used by museums to engage visitors or new audiences, even when the recipes are based on experiences of hardship and food scarcity. The notion of collective belonging - whether through past hardships or in present social and political circumstances - becomes somehow tangible through the intangible idea of food, or even through objects highlighting its absence.

\section{A guest at the table: multiculturalism, migration and intercultural contact}

Firstly, I examine museum uses of food - in display and engagement activities - which address themes of multiculturalism, migration and intercultural contact. Focusing on culinary cultures and traditions in museum work might seem to offer a "safe space" within which museum publics can encounter social difference without antagonism. The universality of food, cooking and eating as a human necessity is seen as a means to bring people together, both literally in museum spaces and figuratively in terms of enabling museum visitors to develop an understanding of "others". The shared nature of food as well as the active sharing of food are used as mechanisms by which to create understandings of a shared humanity and to try to overcome discrimination or racism, but often neglect to reflect the inherent politics of difference embodied within such acts themselves.

Museums which address migration, multiculturalism or issues relating to intercultural contact frequently use food as a means to explore issues of similarity and difference - to make links between different cultures and as a way to bring people together (both figuratively and literally). Food can "provide a focus for practices of communality, especially in collective eating, whether in private or public spaces" (Hage 2010, 424). The migration of ingredients, techniques, recipes and tastes, and the increase in cultural encounters within a place and in the mobility of people, ideas and foodstuffs between places, mean that different kinds of food have become more widely accessible. Simultaneously, familiarity with different cuisines, ingredients or cooking methods has become a way to experience some idealistic aspect of otherness, to signal a habitus of cosmopolitanism which people may find desirable. 
The history of these changes can be seen in displays at the Culinarium Museum, part of the Domäne Dahlem in Berlin - an open-air museum of small-scale historical agricultural techniques - which focuses mainly on family and school audiences in order to educate young people within Berlin about the origins of the food they eat today, and how things were done in the past. One display in particular shows "how Berlin eats", highlighting the wide variety of snack foods available within the city whose origins lie far beyond Berlin or even Germany. The German title of the display, "so isst Berlin", includes a word play on "isst", meaning "eats", and "ist", meaning "is" - words which are distinguishable from one another in the written form but not in the spoken form. In this case, the display and information make subtle connections between food diversity and population diversity, and how these contribute towards the city being what it is - without using images of people.

Taking food as a vehicle for addressing issues of migration, multiculturalism and interculturalism allows museums to depart from the use of people, which can create pitfalls connected to issues around supposed representativeness, the possibility of stereotyping, discrimination and prejudice (whether unconscious or otherwise). The notion of coming around one table, as a metaphor for communication across cultures, is also present in a tangible form within the Culinarium, where visitors are invited to sit at a table, with places set with cutlery, plates and teacups. The teacups are in fact audio speakers which visitors can lift to their ear to listen to. Each place setting provides information about eating habits and customs from around the world - making the familiar act as a vehicle for the unfamiliar.

The House of European History in Brussels has also used food as a means to address the issue of multicultural belonging: "Interactions", the first temporary exhibition, included a section on "the kitchen, living room and bedroom" where the kitchen stood for the idea of different flavours as symbols of cultural contacts and exchange, of familiarity and difference (https://historia-europa.ep.eu/en/interactions). The sense of representing, and perhaps also creating, a community where difference is celebrated rather than used to divide or to antagonize is key to these museums' approach to food as part of multiculturalism, migration and diversity in contemporary populations. In order to achieve this, it is necessary for the museums to focus on the positives and to appeal to happy feelings or memories in their visitors. As the director of the Museum of European Cultures in Berlin says in relation to the core mission of her museum: "the mission really is to address a wider public, to different target groups. And, really, the wish is that people come into our house, and they should simply feel at ease there" (Tietmeyer 2017). She also describes her museum as based on the idea of cultural contact and encounter, using objects to illustrate specific ideas - such as "cultural hybridity and mobility [...] borders [...] via trade, via travelling migration [and] media", as well as taking a strong role within public debates about refugees and society (ibid.). 


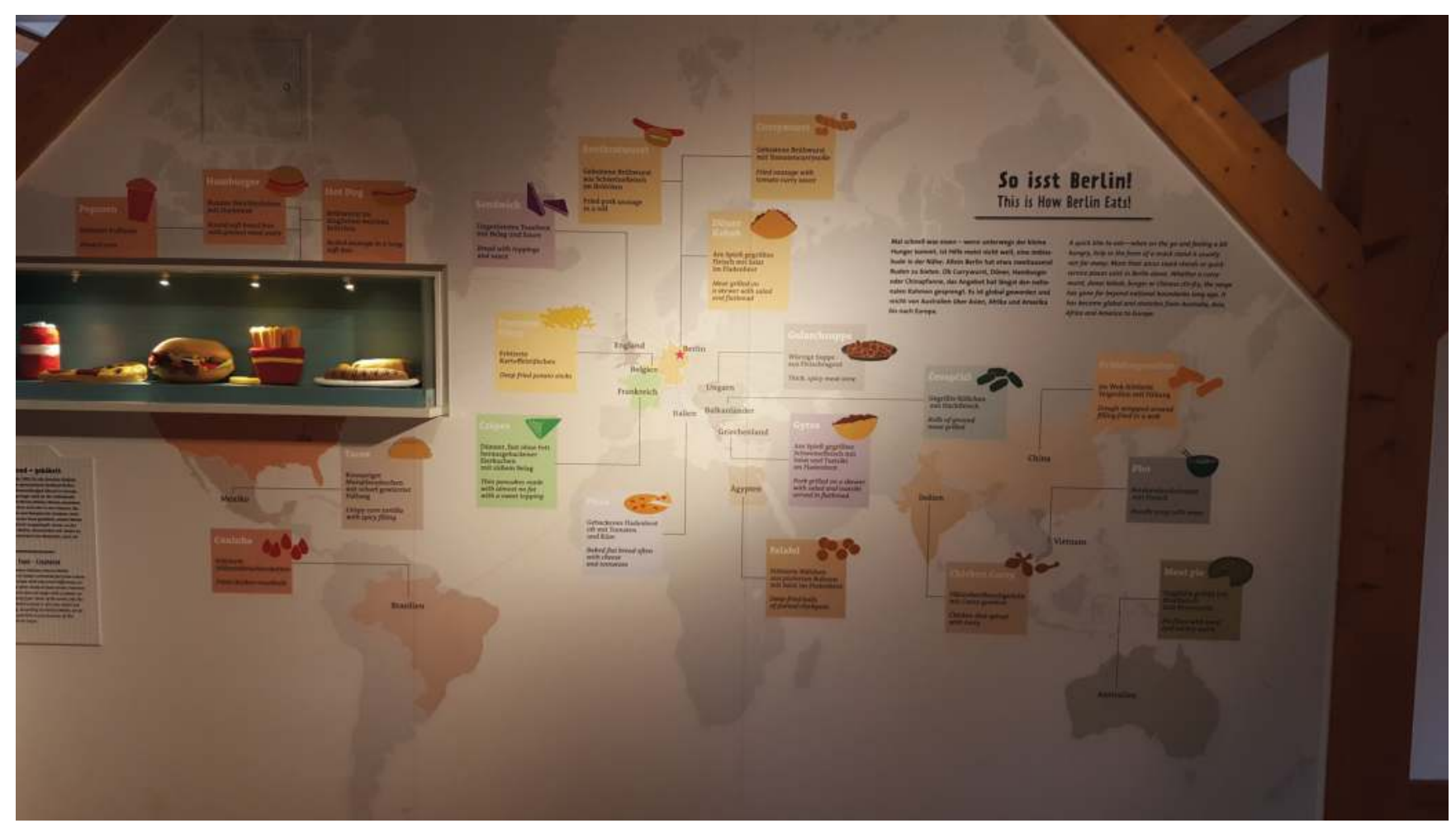

Figure 6.I CULINARIUM exhibition as part of Open Air Museum Domain Dahlem Berlin, display: "So isst Berlin”. Photo: Susannah Eckersley, with thanks to Open Air Museum Domain Dahlem 


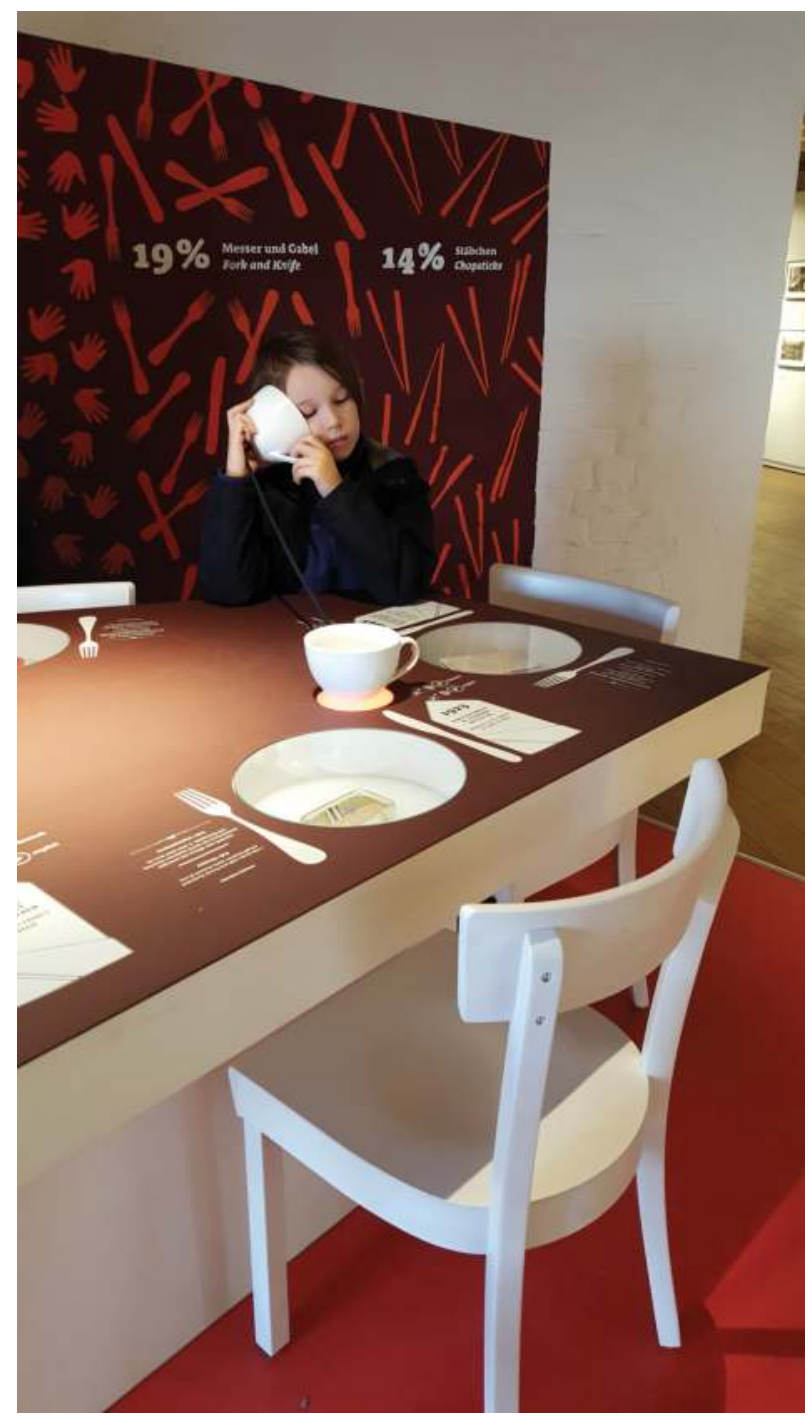

Figure 6.2 CULINARIUM exhibition as part of Open Air Museum Domain Dahlem Berlin: teacups and table setting display. Photo: Susannah Eckersley, with thanks to Open Air Museum Domain Dahlem

What does a large plastic doner kebab advertising sign tell museum visitors about Europe? The Museum of European Cultures (MEK) in Berlin uses a small number of large objects from its collection to act as symbols for, or pointers towards, the bigger issues of relevance to Europe today and in recent times. The 
doner kebab is a case in point, representing not only the large Turkish communities of Germany, but also the wider history of migration to and within Europe, and how this has influenced the everyday surroundings, lives and habits of people and places (see also Macdonald 2013, 126-7). The director of MEK points out that when visitors during guided tours discuss culinary cultures and are shown the doner kebab as a key part of fast food, the fact that the doner kebab in bread was "invented in Berlin and not in Turkey" (Tietmeyer 2017) is an important means to unsettle their expectations and to create a learning moment.

So, while the plastic doner kebab appears to be a rather benign object, one which is perhaps even banal in its everyday-ness, and simultaneously humorous as a result of being placed out of context within a museum instead of on a shop front, it also has a political, social role to play in the museum. Almost resembling a pop art piece through the incongruity of its display, its apparently benign nature as an "easy" symbol of migration, of multiculturalism and of interculturalism within Europe is further disrupted by information (and possible prior visitor knowledge) relating to the so-called Döner murders - an infamous series of murders committed against Turkish residents and others with immigrant backgrounds in Germany. The discovery that the murders were committed by members of a neo-Nazi cell in Germany, and not as a result of victim complicity in organized crime as had been assumed initially by the police, highlighted not only the issue of far-right terrorism within Europe, but also the presence of racism and prejudice within the German police and society (see Saha 2017). The MEK takes migration as a particular focus for its temporary exhibitions, with at least one exhibition on the topic each year (Tietmeyer 2017). The director makes clear that they understand the politics of this topic and the positionality of a museum within this debate, saying: "of course, we are not neutral, and we are somehow also political, in that we are reacting on society crises or debates, but [...] the state is in the background [...] we have the freedom to do what we think is important" (Tietmeyer 2017).

Museum activities use participation in the processes of cooking and eating, or sharing the experience of preparing food, and of consuming, as an immersive means to achieve "intercultural" communication, while simultaneously using the unfamiliar as a route to familiarity. The MEK in Berlin has an annual cultural days festival, "Kulturtage", focused on a different nation, region or city and the people living in it each year. Part of this includes the sharing of food for the 20th anniversary of the MEK in 2019 the Kulturtage theme was "Cafe Europa: essen verbindet" ("Café Europe: food connects"), taking a broad view of Europe and the people living there, specifically through the means of food. The positive effects of migration, mobility and cultural transfer are expressed through the changes to food and nutrition and the significant role of "culinary migration to contemporary lifestyles" (MEK website 2019). The events enable the museums to act "as a forum for cultural encounters [...] different communities and different cultural institutes, or the embassy, they all try to present their 


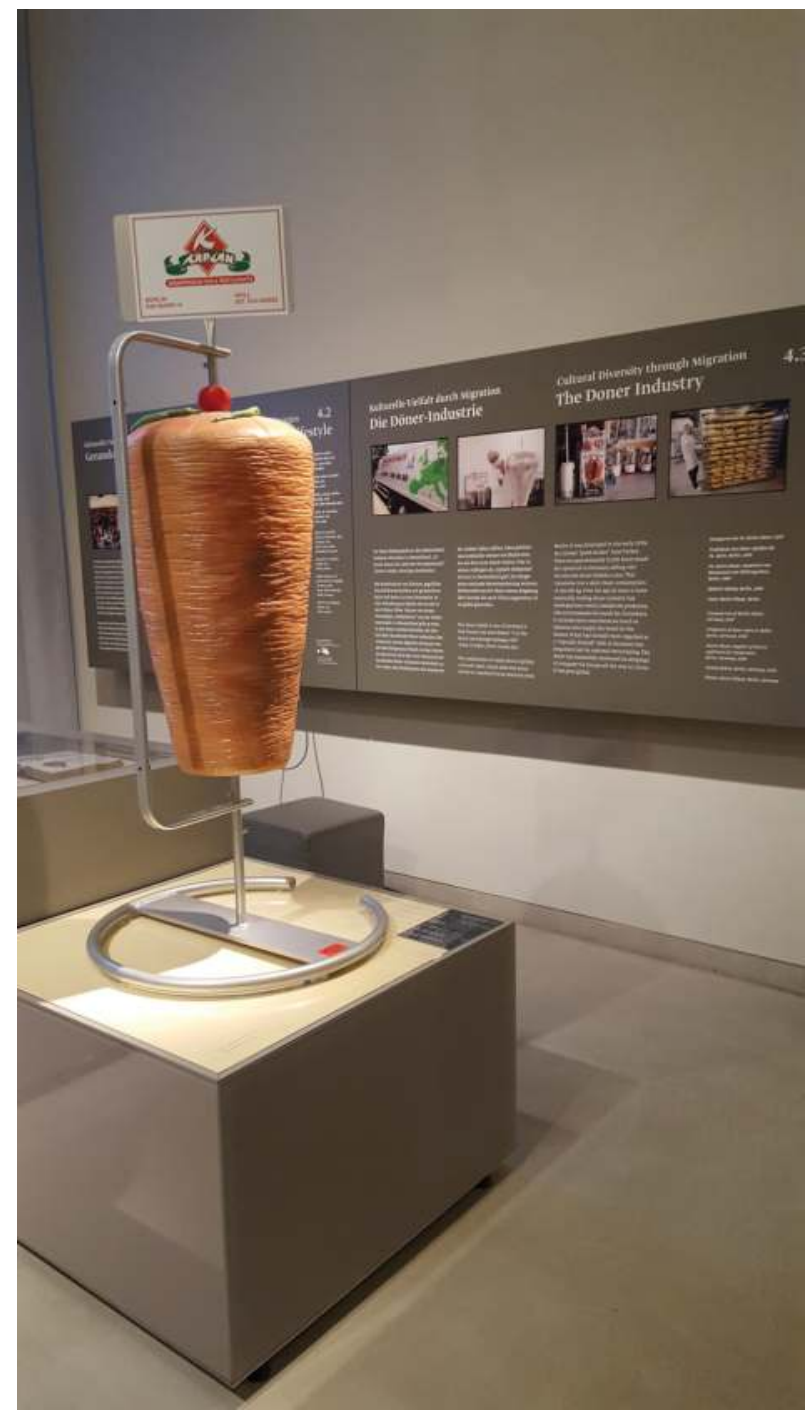

Figure 6.3 Döner kebab display, Museum Europäischer Kulturen - Staatliche Museen zu Berlin. Photo: Susannah Eckersley, with thanks to Museum Europäischer Kulturen - Staatliche Museen zu Berlin

way of life, or aspects of life and their culture [...] and then they get in contact with different people who are visiting the events and the exhibition. And this is really lived cultural contact. So, we try to live Europe" (ibid.). The website text specifically states that they not only want to strengthen relationships 
with their formal partner organizations, and to offer visitors the chance to discover different ways of life, but also to address "people of a non-German background, to discover the museum and see and enjoy familiar things from their homes. Through this we want to make a contribution towards affirming peoples' self-images and better social integration" (MEK website 2019, own translation). Tietmeyer highlights the crucial significance of participation for the MEK: "since our foundation, we have this participatory approach $[\ldots]$ we collaborate with people, not doing exhibitions about the people, but with the people $[\ldots]$ in that the people are doing their exhibition and we are facility managers $[\ldots]$ so, this participatory approach is very, very important to us. It's the core of our profile. And also, the orientation in the present time is very important to us" (ibid.). Following the international "participatory turn" in museums, the limitations of such community participation and the involvement of marginalized groups on individual and group processes of "integration" are now also being researched (see for example, Lynch 2013; Lynch and Alberti 2010).

Other museums offer bookable cooking courses, connected to different national cuisines or linked to special exhibitions or event programmes. Notably those on offer at the UK Migration Museum have a migrant individual as the course leader, who not only guides the participants through recipes from their homeland and the food preparation, but who also acts as a discursive host during the shared meal at the end. For paying participants this offers the opportunity to learn a new recipe from a possibly unfamiliar cuisine or culture, while also allowing them access to an individual from that culture in order to ask questions or to listen to personal stories in addition to the shared experience of the food. The notion that "food is so good at triggering dialogue" (Steinberg 2012, 83) has shaped the use of food in migration-focused museums internationally. This strategy can also be found in other non-museum situations and organizations, such as a recent example discussed on Twitter of the "Tandem" project in Hamburg where a local and a refugee cook together, tell their life stories and are filmed in the process, and the "Stories and Supper" (www.storiesandsupper.co.uk/) organization of supper clubs which works with local communities and refugees in south-east England.

The notion that cooking and eating together is a way to create common understandings may be both valid and valuable on the one-to-one level of interpersonal communication, but becomes more problematic when scaled up as a strategy for implementing broader "integration" measures or to provide evidence of them. The simplistic perspective that having a place at the table (whether this is a table for a shared meal or the metaphorical table of social, cultural or political influence) overcomes structural inequalities is naive - "such utopian desires imagine eating to be a solution to the fractious malaises of the world but are predicated on sentimentalized and dehistoricized understandings of the power of consumption" (Mannur 2007, 27). At the same time, however, the recognition, appreciation and enjoyment of "migrant food" by members of 
the "host society" constitute a valuing of the contribution of "newcomers" and their skills (Hage 2010, 425).

The use of willing individuals as migrant or refugee guides in museums with the intention of widening the interpretation of the museum through new perspectives on the museum objects is not entirely new (see the Multaka project in Berlin, https://multaka.de/en/startsite-en/, and now also in Oxford, www.prm.ox.ac.uk/multaka-oxford-0). However, this approach carries the risk of the migrants themselves becoming "the object" or "beneficiary", thereby reinforcing asymmetric power relationships between the migrant, the museum and other museum visitors (Eckersley 2019; Lynch 2013; Lynch and Alberti 2010), and that, for potential participants, their involvement appeals to a sense of "orientalism". Furthermore, a common trope of public representations and framings of refugees and migrants - found in museums as well as in the media (Chouliaraki and Stolic 2017) and elsewhere - is not one of migrant agency, resilience or determination, but rather a "tendency in the study of migration that wants to make migrants passive pained people at all costs" (Hage 2010, 417). Instead, Hage argues that memory and the enactment of practices of homeliness among migrants is a settlement strategy: "for migrants [...] memory belongs to the construction of the future. It is only in certain pathological situations that memory becomes a form of entrenchment in the past" (ibid., 419). In this sense, museum involvements with migrant and multicultural communities could be categorized as a form of "reflective nostalgia" (Boym 2001), where the process of remembering allows a differentiated perspective on the past, in relation to the constructions of a new future, rather than a more problematic "restorative nostalgia" (ibid.) which aims to somehow return to an idealized past. The examples here make evident that while the use of food, cooking and eating by and in museums is often intended as a means to mobilize positive understandings of different cultures and shared human experiences, there are underlying problems if museums see food as apolitical. In fact, several of the examples show that the social tensions, antagonisms and problematic misconceptions of difference and similarity which museum staff may be aiming to overcome might even be reinforced if a museum presents visions of "otherness" rooted in orientalism.

\section{A place for the past and the past in its place: nostalgic engagements with food}

Secondly, I consider how food is used in museum contexts where the appeal to visitors is to engage nostalgically with a certain view of the past, in connection to the specificity of place - even when this is not an "authentic" place. I use data from Beamish Open-Air Museum in England, in which food history is a key part of a museum experience based on recreating past times and places. $^{2}$ The museum's strategy for food swings between Proustian sentimentalism, didactic intent and commercial gain (as seen in other museums, such as the 
Tenement Museum - Steinberg 2012), and the result is an offer to reminisce, and literally to consume the past as pure and wholesome - through immersive re-enacting as a form of "restorative nostalgia" (Boym 2001). More difficult histories relating to food - such as those relating to shortages, class inequalities and colonialism - are not absent, but they are rather toned down compared to the invitation to indulge in celebratory, nostalgic time travel through food. Our fieldwork at Beamish took place in the aftermath of the Brexit referendum in the United Kingdom, when some visitors took the time-travelling experience of the museum as a reminder of a (mythic) past of bucolic social homogeneity, prior to immigration and the interference of the European Union - one that it might now be possible to recover and to relive.

For Boym (2001), restorative nostalgia is when nostalgia is utilized in order to recreate a positive sense remembered from or conjured out of memories of the past, rather than to face the realities of the present. Museums may do this in ways which are both collective and individual - in appealing to visitors' individual memories (perhaps of childhood) or in responding to a collective social, cultural or even political mood in relation to specific parts of the past.

To give another example, the Culinarium's display on the different food products consumed in East and West Germany during the Cold War are designed according to this tendency to respond to food in museums from a nostalgic point of view, using old picture frames for photographs of food items and packaging. The two display boards face one another, allowing the visitor to look from one to the other and to make comparisons or to note contrasts between the "two Germanies". This exhibit plays on feelings of nostalgia for foodstuffs that were available in each country, but with a particular - albeit rather benign - appeal to Ostalgie (nostalgia for East Germany, a term coined in the 1990s and addressed in detail by Arnold-de Simine 2013, 160-83). Berlin's GDR Museum, however, seems to present food rather more overtly cleansed of the difficult political and social history of the German Democratic Republic (GDR). Arnold-de Simine (2013) provides a detailed analysis of this museum in relation to Ostalgie and the tendency of German museums dealing with the GDR to address either the "banal" everyday experience or state oppression, but not to bring the personal and the political together. In their semi-immersive, interactive exhibition, where visitors can enter a reconstructed East German Plattenbau flat and handle objects in the kitchen for example, the GDR Museum appeals particularly to foreign tourists, rather than necessarily German visitors - for some of whom this history may still be too close to reconcile such "playful" treatment of it in a museum. From 2010 the museum also included a restaurant, the Domklause, serving "authentic" favourite dishes from the GDR period (Arnold-de Simine 2013, 178); however, the restaurant was closed in March 2015 and a statement about this appears on the museum website (www.ddr-museum.de/en/blog/archive/ goodbye-isnt-easy-ddr-restaurant-domklause-closes-till-31st-march-2015).

Currently, the GDR Museum makes increasing use of social media platforms such as Twitter to engage with a public beyond the walls of the museum and to 


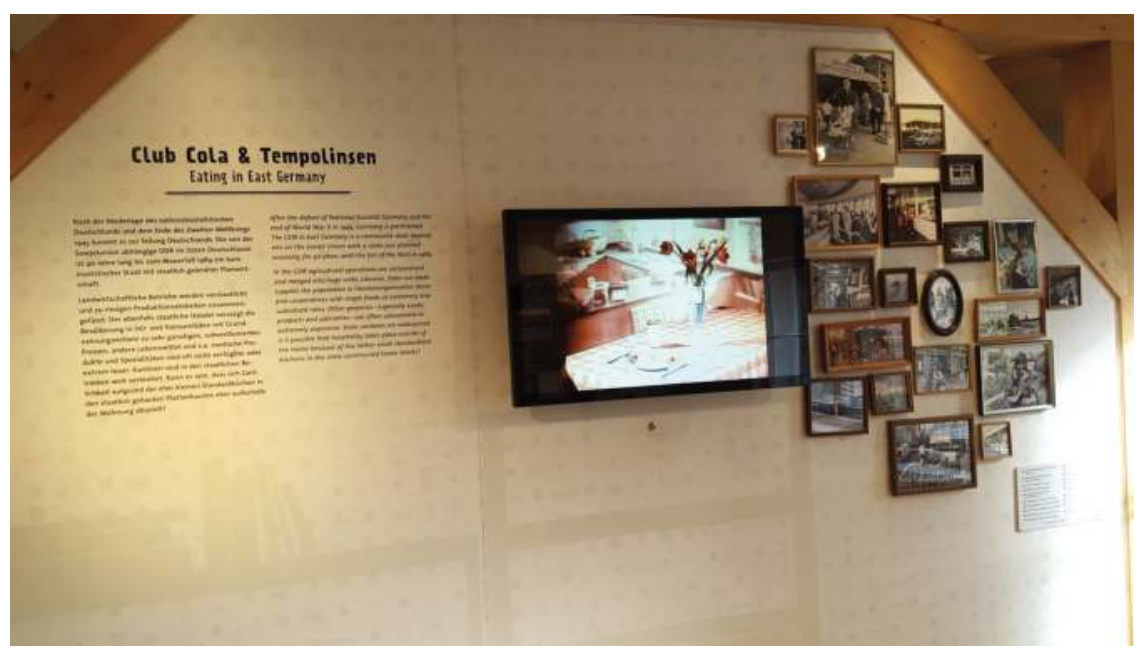

Figure 6.4 CULINARIUM exhibition as part of Open Air Museum Domain Dahlem Berlin: display board "Eating in East Germany". Photo: Susannah Eckersley, with thanks to Open Air Museum Domain Dahlem

inspire people to share their memories of the GDR. Food is a frequently recurring theme on their Twitter account, where celebrations such as Christmas and New Year, regular everyday practices or products from the GDR which are now lost - such as the triangular school milk cartons, or particular food brands - are presented online with a request for people to respond with their memories. In this way, the museum encourages people to share personal aspects of their lives not only with the general public via Twitter, but also potentially as a rich source for museum curators, educators and historians of the time. Interestingly, however, such personal stories or "oral histories" are only collected via social media, and not included in the museum displays (Arnold-de Simine 2013,181). By playing on the sense of nostalgia, resulting from the museum's focus on apparently non-political objects and memories, it plays an important role in the sense of Ostalgie. Of course, Ostalgie is not an essential component of displaying objects related to food in the GDR. For example, the Dresden City Museum has many similar objects on display, but it does not rely on the overtly nostalgic designs or the playfully nostalgic display styles of the Culinarium and the GDR Museum.

At both the GDR Museum in Berlin and Beamish Open-Air Museum in the United Kingdom, personal nostalgia is layered into a sense of political amnesia, particularly when it comes to food. This is despite both museums including displays on difficult aspects of the past - on internment in the GDR and on the home front during World War II at Beamish. Food is a significant 


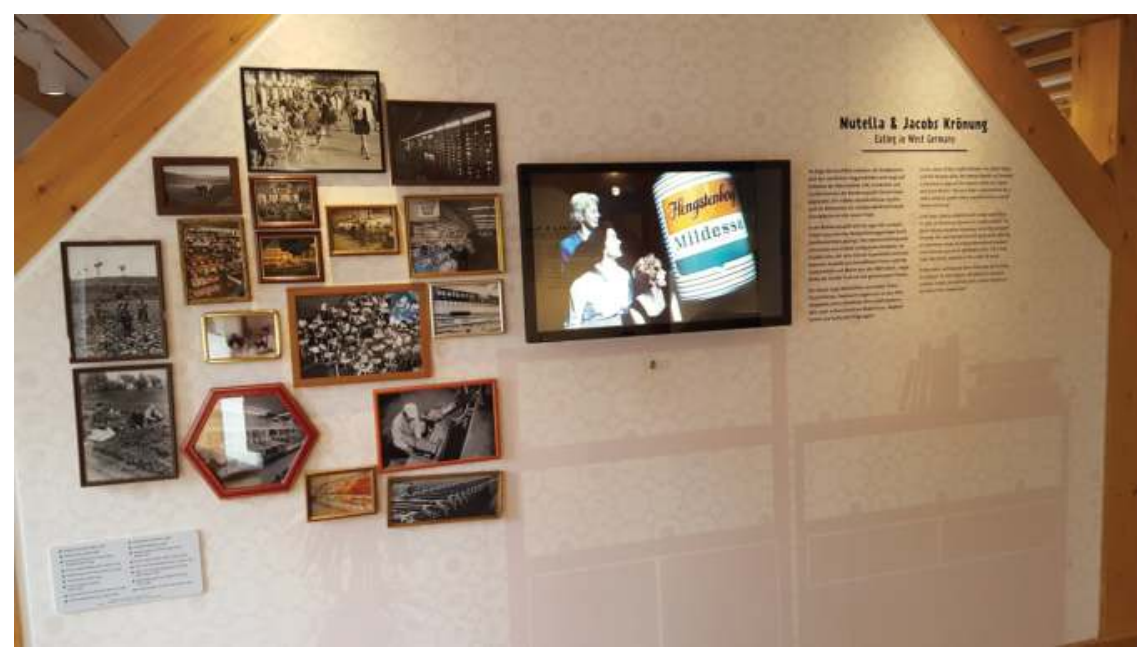

Figure 6.5 CULINARIUM exhibition as part of Open Air Museum Domain Dahlem Berlin: display board “Eating in West Germany”. Photo: Susannah Eckersley, with thanks to Open Air Museum Domain Dahlem

part of any visit to Beamish - as a large, open-air museum it caters to families and other visitors who come for a full day out, and who need to eat on site. In fact, the need to provide food for visitors has become a key part of the historical attractions, with several "exhibition" spaces (reconstructed historic homes, shops or other buildings) acting as places where food and drink are not only prepared according to traditional techniques but also sold to visitors. The Beamish museum site includes a working sweet shop, a pub, a bakery and a fish and chip shop, where visitors can "feel" part of a historical experience, watching sweets being made in the traditional style before buying some, or waiting in line for the coal-fired fish and chip shop to prepare their order for lunch. The participatory aspect of the food experience, combined with its sensory nature - seeing, smelling and finally tasting the food - make it extremely popular amongst visitors, while also aligning with research on how memories are made and retrieved. The staff at Beamish consider the focus on food crucial: "when the visitors go into the sweet shop [...] the smell of the sweets being made brings memories back, doesn't it? And that's really important [...] I can't imagine doing it without the food" (Anon. B 2016).

The idea that the techniques (and therefore perhaps some of the flavours) of the food preparation are no longer in use elsewhere adds to the sense of nostalgic remembering of times gone by. Such use of food within the open-air museum is undoubtedly a very successful marketing strategy, and visitors make great use of the food outlets available to them at Beamish. However, this use of food 
and nostalgic remembering and re-enacting has recently been taken further at Beamish through the development of a series of bookable "experiences" some connected to traditional crafts or skills (ranging from basket weaving to steam-roller driving) and others connected to food. While a traditional breadmaking or sweet-making workshop may be seen as "good clean fun", the inclusion of a "1940s wartime cooking" workshop within the range of food-related experiences on offer to paying customers for entertainment is an indication of the rose-tinted nostalgia being sold. All such experiences include the opportunity for participants to dress up in period costume, as a way to facilitate imagining themselves within the circumstances of the time. The 1940s experience includes a meal of spam sandwiches and tea - a light-hearted attempt to recreate the food privations of rationing in the United Kingdom - and recipes using mock ingredients. As another Beamish staff member points out, Beamish experiences are "more than a museum, it's an experience, it's an immersive aspect of your life which will always be with you as a memory, so you take that memory away with you" (Anon. A 2016). This light-hearted approach to the purchase and consumption of "food experiences" may be comparable to that at the GDR Museum with its former inclusion of a working restaurant as an example of "restorative nostalgia" (Boym 2001). Arnold-de Simine points out that the significance of Ostalgie for GDR food products was less to do with the actual foods or their flavours, but rather more connected to the loss of "cultural capital and expertise" and that such "restorative nostalgia" should be seen as an "attempt to regain agency in modelling the future" (Arnold-de Simine 2013, 175).

The Beamish "wartime cooking experience" can be considered an innovative way to educate visitors and to create a deeper, more personal response to the history of everyday life in the United Kingdom during World War II. On the other hand, it reflects a growing trend in the United Kingdom to look back at the past through a nostalgic filter, through which the notion of overcoming hardship is celebrated. This plays into nostalgic beliefs perpetuated by the discourse of "leavers" in relation to Brexit - the notion that the United Kingdom prior to its membership in the European Union was somehow "better" and that if only everyone believed this, it might be possible to return to such an idealized past - much like people can when visiting Beamish. This is in stark contrast to the intentions of staff at Beamish, who state categorically that while they aim to provide a historical perspective, they try to do this apolitically: "staff recently [...] have reported that they have quite challenging conversations with visitors at times, particularly around culture, ethnicity. We encourage all our staff and volunteers to be very, very neutral in their responses" (Anon. A 2016).

Addressing the current sense of purpose and mission of the museum, Anon. A says: "our mission is to put the visitor first" (2016). As a commercial rather than a fully publicly funded museum, the need to act commercially, seeing the visitor as a customer, therefore fits a business model of self-sustainability. However, a business which happens to be a museum also operates under a sense 
of public value, of trust and of expertise. While visitors to Beamish are unlikely to be aware of the differences between a museum managed and funded by local or national government and one which is a private, commercial operation, this difference becomes evident in the lack of critical engagement with the politics of the past in relation to the present. The "restorative nostalgia" enjoyed by visitors at Beamish and at the GDR Museum is therefore to some extent created by both museums' intentional distancing from political issues and current affairs, allowing visitors to step into a mythical world of the past uncomplicated by political realities.

\section{Food as Ersatz for traumatic loss: mourning a lost future}

Within the context of museum displays, the absence of food can become a proxy (in German literally an Ersatz, ironically also the word adopted in both German and English to describe replacement foodstuffs during rationing) for attempts to come to terms with or to gain recognition for personally and politically difficult pasts. The emotive appeal of museum objects which combine the familiarity of food and cooking with the challenging impact of scarcity and hunger connects to theories of attachment and adjusting to traumatic change (Hirsch and Spitzer 2006; Parkin 1999). This emotional appeal becomes heightened when the objects relate in a non-nostalgic manner to the lack of food, to scarcity, hunger and privation. The absence of food links personal tragedy with international conflicts and historical atrocities, including the Holocaust.

Food utensils, such as crockery and cutlery, which have historically had a role in conveying the status of a family or individuals, perhaps being linked to previous generations or to the idea of "the family silver" or "the good china" being kept for special occasions, can become symbols of individual significance during difficult times, or during separation from loved ones. Such objects therefore stand not only for the experiences of food scarcity and the heightened significance of cooking and eating utensils, but also become a proxy for associated loss of individual agency or control and for a subsequent desire for recognition of past suffering or for the loss of imagined futures.

One example of this is at the Tränenpalast Museum in Berlin - in the buildings at the Berlin Friedrichstrasse station, where limited visits between East and West Germany and some permitted emigration from the GDR took place. Suitcases containing some of the key personal possessions of individuals leaving the GDR are displayed, including one with a china plate, teacup and saucer. Not the most practical items to take away, either in terms of packing them or their future necessity, these objects have a significance that therefore goes beyond their practical purpose. Symbolizing the sense of attachment to family traditions in the face of disconnection and displacement, the dishes become an indicator of nostalgic loss, and of a desire to start afresh without entirely leaving the past behind, 
but to "engage in home-building in the here and now" (Hage 2010, 420), much as the contemporary migrants and refugees discussed in the first section.

Scarcity of food as a result of war is evident in displays from museums across Europe. In some of these museums food, cooking and eating appear to be a peripheral concern, almost missing from the museum - but on second glance, the few objects which do relate to this are deeply significant, and their sparsity is telling in itself. The main collection of food-related objects in Dresden's City Museum is from the GDR collection; only a few food-related objects from the earlier 20th century are found. However, those that are present relate to scarcity. For example, a decorative plate from 1916 with a rather foreboding inscription ("das Essen wird knapp, gewoehnt's Euch ab" - "food is getting scarce, get used to not having it"). This sentiment of food scarcity as integral to wartime at home is echoed in the Museum of the Second World War in Gdańsk - particularly in the children's exhibition. Here visitors are invited to walk through a series of exhibition spaces, within which the same living room of a city apartment is reconstructed at three different moments during the Second World War (1939, during the war and after 1945). In the living room visitors find a china cabinet and dining table, laid at first with fine china and a silver coffee set and decorative elements indicating the status of the family living there. As the war progresses, visitors see how, in stages, the dining table becomes bare, with Ersatz products instead of luxuries, then UNRRA food parcels appear and the fine tea set has been replaced by chipped enamel mugs, until the last reconstruction shows the room bombed out and almost bare.

The gradual presentation of wartime food shortages in the Gdańsk museum makes what is evident in the dish in the Dresden museum all the more clear. The museums here do not make entertainment out of food shortages, but rather lead visitors to see the predictable inevitability of individual suffering as a result of war. The objects and displays serve multiple purposes: taken simply, they stand for experiences of food scarcity and the heightened value of cooking and eating utensils; at the same time, they become symbols of the loss of individual agency or control; and finally, they represent the desire for past suffering whether on an individual or a collective scale - to be recognized publicly.

The main exhibition of the Museum of the Second World War in Gdańsk contains numerous objects connecting to food hardship and hunger. Ration stamps and Ersatz food products represented in the children's exhibition reappear in cases addressing the impact of war on civilians, and in those addressing military issues, mess kits are displayed. Later in the chronologically organized displays the focus on appealing to the visitors' emotions seems to become stronger. It is important to note that this museum - its collections, displays and staff - have been the subject of significant political interference from the Polish Law and Justice Party national government since it first opened in 2016, as it was perceived not to sufficiently present Poles and Polish history in the politically preferred "victim-hero" role (Ciobanu 2017; Clarke and Duber 2018; Michalska 2017; Waszak 2018). Objects and photographs 

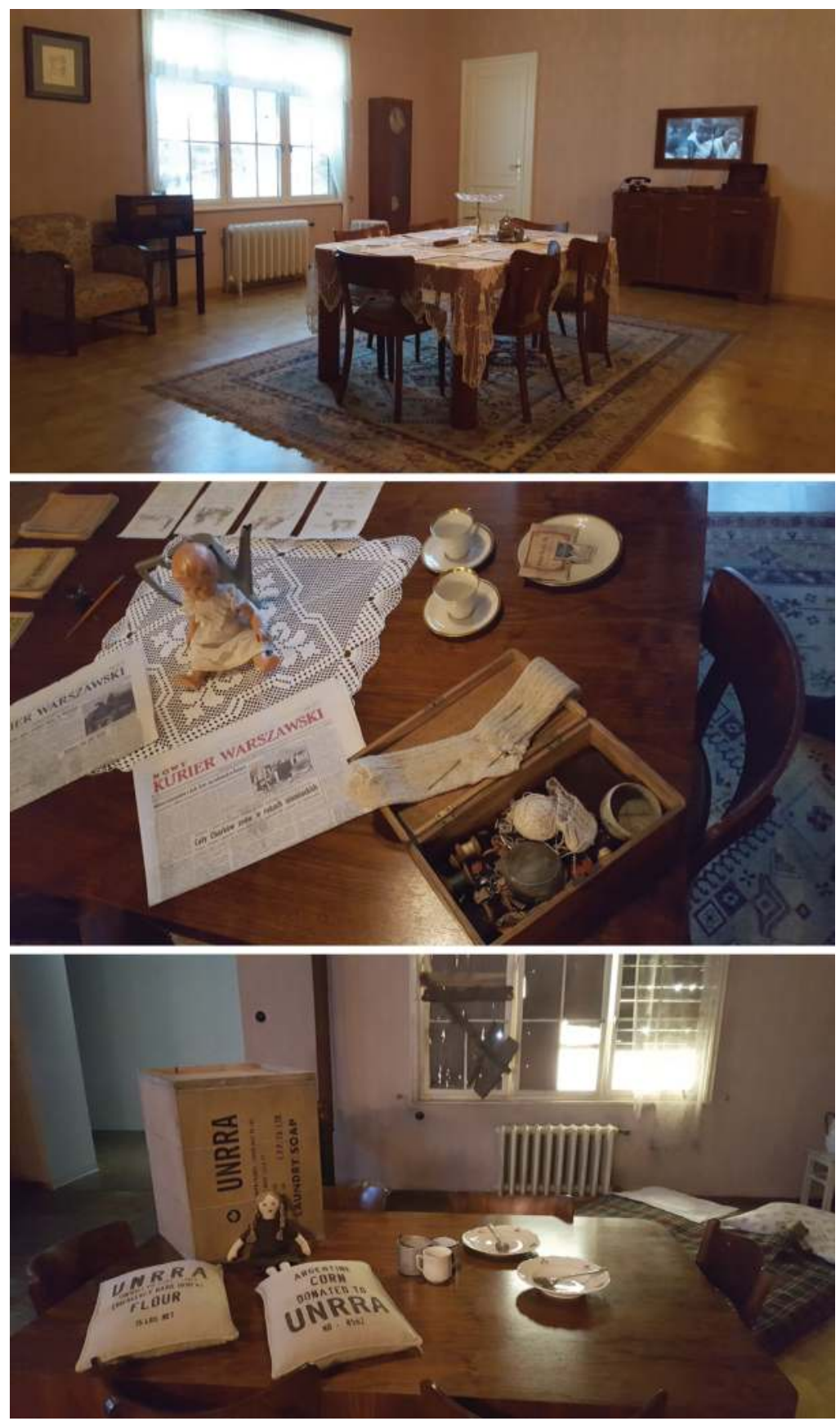

Figure 6.6 a-c Gdańsk Museum of the Second World War, children's exhibition. Photos: Susannah Eckersley, with thanks to Museum of the Second World War, Gdańsk 
relating to hunger - including spoons from Auschwitz and Ravensbrück, a camp bowl from Dachau and objects from Poles executed at Katyn - seem to be displayed not only to inform the visitor, but so as to produce affective responses. Visitors encounter a case containing pieces of bread made according to a recipe used during the siege of Leningrad, as well as a bowl and cup from the Warsaw ghetto. These food-related items from deeply traumatic events in the history of World War II are displayed in highly scenographic installations, where the design of the space which visitors move through appears to be as important in shaping visitor understanding as the objects or interpretive texts themselves. Affective museum interpretation techniques where "talking about food in a time when there was none [...] presents an opportunity to introduce drama and action into the public history site" (Elias 2012, 14, in relation to the Tenement Museum in New York) highlight the apparent paradox of combining food scarcity associated with traumatic pasts in a highly designed, intentionally affective sensory environment - something which creates an unsettling, discomforting effect.

At Auschwitz Museum and Memorial the exhibition and display design is very restrained. Museum cases and visitor spaces are simple and plain, evidently due in part to the fact that little has changed in the look of the museum's presentation style over the years, but significantly premised as it is on the necessity to retain and present the authenticity of the historic site. The restraint of the display cases contrasts starkly with the affective power of their contents. Visitors encounter a huge case full of cooking pots and dishes, and a small display of kitchen utensils - a cheese grater, a wooden whisk, cutlery, a potato peeler - making us as visitors at once aware of the huge and inhuman scale of the destruction at Auschwitz, but also of the everyday needs and individual lives of those murdered there. The food utensils speak of the universal need to eat, something which people imprisoned at Auschwitz were denied, and of the victims' expectation that they would need the means to provide for themselves - of their expectation of life. This dual approach of presenting visitors with the huge scale of the inhumanity carried out at Auschwitz, juxtaposed with the micro level of each individual victim's humanity, bringing them "to life" as individuals, is achieved through different types of objects, including the familiar shoes and suitcases, but the food objects are particularly poignant.

In many of the other museums, recipes or recipe books which make use of only easily available ingredients are employed as a means by which to indicate hardship to visitors. The historically gendered nature of food and cooking is also at play here (as seen in the Tenement Museum, Elias 2012, 27). The apparent simplicity and homeliness of the recipe book, and in particular its association with the traditionally "female domain" of cooking, homemaking and the family, are used as a contrast with the traditionally male-centred experience of war as a military rather than a domestic issue. In 2018 a reproduction post-war recipe book with a New Year's greeting was sent out to those on the mailing list of the Stiftung Flucht Vertreibung Versöhnung (Foundation 


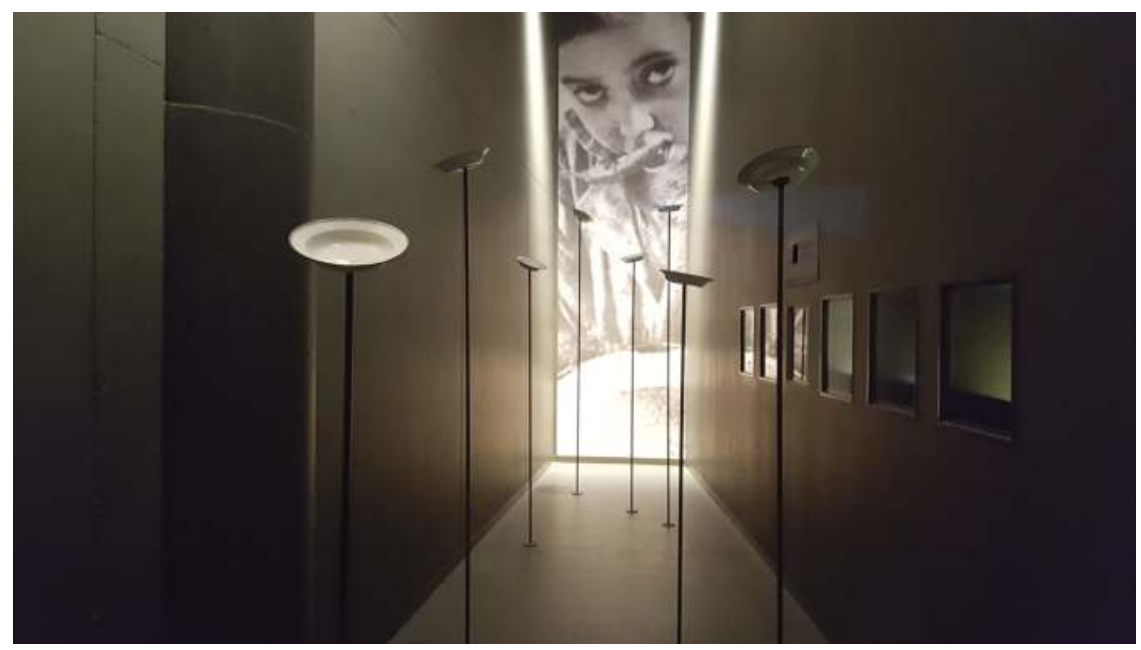

Figure 6.7 Gdańsk Museum of the Second World War, highly designed area with foodrelated content. Photo: Susannah Eckersley, with thanks to Museum of the Second World War, Gdańsk

for Flight, Expulsion and Reconciliation) (SFVV). The SFVV is developing a documentation centre in Berlin following decades of controversy around the idea of a "museum for expellees" based on the German experience of forced migration following the end of World War II.The personal story behind this recipe book and the transmission of the challenges associated with food shortages to a contemporary public can be seen as an attempt to defuse the political element of the object's association with a history which continues to be contested and politically sensitive.

In these cases, food has become an affective, emotive medium through which difficult histories can be made more visible, more tangible and more comprehensible to museum visitors - and perhaps also to a politically sensitive general public - despite the political concerns and at times the controversies surrounding them. In this way, it acts as an Ersatz both for direct political statements and for overt positioning by museums and heritage sites, particularly those which operate within a political realm that is not always sympathetic. Simultaneously, the scarcity of food, in particular when presented as part of the Holocaust and war, can be seen as a means by which visitors are enabled to comprehend human suffering through hunger, at times within the extreme context of genocide. The dishes and utensils displayed at Auschwitz not only do this, but also enable visitors to imagine the past lives - the time before the Holocaust - in addition to the lost futures of all those who were killed. This relates to Žižek's idea of nostalgia for unrealized futures (Žižek 2008, 141), 

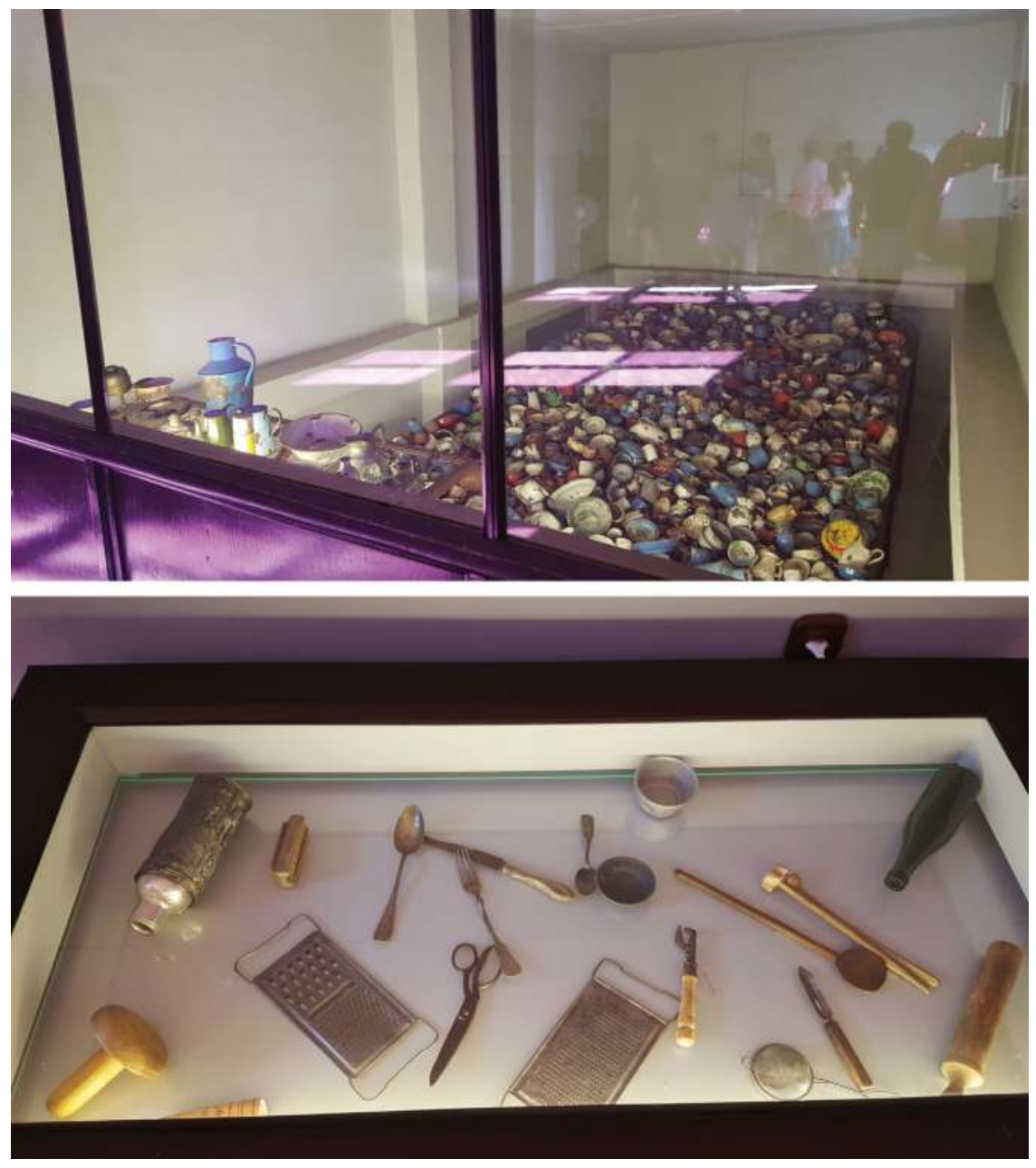

Figure 6.8 a. Auschwitz Museum, large display of cooking pots.b. Auschwitz Museum, small display of food utensils. Photos: Susannah Eckersley, courtesy of Museum and Memorial Former Nazi-German Concentration Camp Auschwitz-Birkenau

where the process of looking back enables the potential to consider alternative futures. Although the presentation of food scarcity, hunger and starvation seen in these cases might not appear nostalgic in the sense of happier times, the Auschwitz example in particular suggests a mixing of elements of both reflective and restorative nostalgia to create a more differentiated, multi-layered form of nostalgia. Arnold-de Simine addresses the complexity of heritage sites 
and nostalgia (Arnold-de Simine 2013, 54-67) in relation to trauma, seeing both emotions as "on the threshold between remembering and forgetting" (ibid., 62), with traumatic memory and post-traumatic stress disorder (PTSD) both characterized by a sense of bringing the past into the present and future so almost the opposite of a "restorative nostalgia". Instead of attempting to recreate a lost past (like the restorative nostalgia at Beamish or the GDR Museum), or to create a better future in light of the past (like the reflective nostalgia at the $\mathrm{MEK})$, it rather addresses the significance of the losses in the past, while gently reminding us of the precarious nature of stable societies as a nod to possible difficult futures. As such it could perhaps best be described as an anticipatory nostalgia - where the possibility of future loss or change is anticipated at the same time that the past is mourned.

\section{Conclusion}

Food in museums is therefore not only a proxy - or Ersatz - for political issues, but also a means through which different notions of nostalgic placemaking, attachment or "finding one's place in the world" are being enacted and constructed at times with, on behalf of or even in opposition to people seen as "other". This can be limiting, in the sense of fixing predetermined notions of attachment of people to place through the means of food - as Sutton points out, "the attachment of taste to place can be seen as one of the tautologies of food and identity" (Sutton 2010, 216). This echoes the way that "culture" is sometimes seen as a category of identity that is fixed to a nation, language or religion for example, rather than being constantly reconfigured in relation to changing environments and experiences - part of changing processes which connect people and place across time and space (Eckersley 2017). The different ways in which food, place, belonging and difference are put to work in these museums, whether in order to mobilize a conscious critical political engagement, or in attempting to disengage from contemporary politics through a supposedly apolitical, historical presentation, is always about addressing identity and belonging.

All the main museums analysed here - in Gdańsk, Auschwitz and Beamish, the MEK, the Culinarium and the GDR Museum - are museums with very different roles, purposes and audiences. They are located in different countries and operate on different scales, yet in each of them food is being used as a proxy or Ersatz for difficult political issues - whether historical or contemporary. The affective, sensory nature of food combined with its universality as both human necessity and desire enables the museums to speak to different forms of nostalgia and even loss. In the case of the multicultural museum, food enables people of different geographic origins to engage in processes of"reflective nostalgia", reimagining for the future, to create - for a short time at least - a world where differences are welcome and the encounter with the unfamiliar is desired. At Beamish and the GDR Museum, we see different approaches to 
the selective recreation of the past, as a means of "restorative nostalgia", where the complexities and contradictions of difficult or contested pasts are smoothed out, in order to provide an entertaining learning experience for visitors. In the museums where food scarcity and privation is presented, it is as a symbolic Ersatz for the most difficult loss - that of human lives and futures. The food objects here are used to enable visitors to grasp the realities of atrocities which are simultaneously somehow unimaginable. They do this at the same time as subtly unsettling the apparent security of the present and future, through what I term anticipatory nostalgia, where the possibility of future loss and future mourning is always part of remembering past losses.

Food is used in museums in multiple politicized ways, which may not always be immediately evident, but which speak to difficult histories and memories of the past, as well as to troubled or challenging present times. Different forms of nostalgia are at play in these examples - the reflective and restorative nostalgia identified by Boym (2001) and the newly identified anticipatory nostalgia. These provide not only a means to analyse the use of food in museums, as in this chapter, but also offer a tool for analysing presentations, performances and enactments of difficult histories both more generally and within wider spaces of circulation beyond the walls of the museum.

\section{Notes}

1 Some of the early ideas from which this chapter has developed were formed in collaboration with Christopher Whitehead, and from presentations we each gave at a workshop organized by Ilaria Porciani in Bologna in 2018. Chris undertook the fieldwork interviews at Beamish Open-Air Museum and has given me permission to use this material here, for which I am very grateful.

2 Collected by Christopher Whitehead and used with his permission here.

\section{References}

Arnold-de Simine, S. (2013) Mediating Memory in the Museum: Trauma, Memory, Empathy, Basingstoke: Palgrave Macmillan.

Boym, S. (2001) The Future of Nostalgia, New York: Basic Books.

Chouliaraki, L. and Stolic, T. (2017) "Rethinking humanity and responsibility in the refugee 'crisis': A visual typology of news media”, Media, Culture \& Society 39(8), 116277. www.lse.ac.uk/media-and-communications/assets/documents/research/projects/ media-and-migration/Chouliaraki-and-Stolic-Refugees-Visual-SUBMISSION.pdf accessed 10 January 2009.

Ciobanu, C. (2017) "Poland's WWII museum under political bombardment", Politico. www.politico.eu/article/polands-wwii-museum-under-political-bombardment/ accessed 10 January 2019.

Clarke, D. and Duber, P. (2018) "Polish cultural diplomacy and historical memory: the case of the Museum of the Second World War in Gdańsk", International Journal of Politics, Culture, and Society. doi: https://doi.org/10.1007/s10767-018-9294-x. 
Eckersley, S. (2017) "People-place-process and attachment in the museum: a new paradigm for understanding belonging?" Anthropological Journal of European Cultures 2017(2): 6-30.

Eckersley, S. (forthcoming) "Encountering authenticity in the contact zone? Museums, refugees and participation”, in S. Brüggerhoff and D. Kimmel (eds), Museen, Orte des Authentischen, Schriften des RGZM: Mainz.

Elias, M. (2012) "Summoning the food ghosts: food history as public history", The Public Historian 34(2): 13-29.

Farrar, M. (2011) "Amnesia, nostalgia and the politics of memory", Political Research Quarterly 64(4): 723-35.

Hage, G. (2010) "Migration, food, memory, and home-building", in S. Radstone and B. Schwarz (eds), Memory: Histories, Theories, Debates, New York: Fordham University Press, 416-27.

Hirsch, M. and Spitzer, L. (2006) "Testimonial objects: memory, gender, and transmission", Poetics Today 27:2.

Holtzman, J. (2006) "Food and memory", Annual Review of Anthropology 35: 361-78.

Lynch, B. (2013) "Reflective debate, radical transparency and trust in the museum", Museum Management and Curatorship 28(1): 1-13.

Lynch, B. and Alberti, S.G. (2010) "Legacies of prejudice: racism, co-production and radical trust in the museum", Museum Management and Curatorship 25(1): 13-35.

Macdonald, S. (2013) Memorylands. Heritage and Identity in Europe Today, Abingdon: Routledge.

Mannur, A. (2007) "Culinary nostalgia: authenticity, nationalism, diaspora", MELUS 32(4): 11-31.

Michalska, J. (2017) “Outcry over Polish government's changes to Second World War Museum", The Art Newspaper. www.theartnewspaper.com/news/outcry-over-polishgovernment-s-changes-to-second-world-war-museum accessed 10 January 2019.

Museum of European Cultures website (2019) www.smb.museum/museen-undeinrichtungen/museum-europaeischer-kulturen/veranstaltungen/europaeischekulturtage.html accessed 10 January 2019.

Parkin, D. (1999) "Mementoes as transitional objects in human displacement", Journal of Material Culture 4: 303-20.

Saha, M. (2017, 12 September) “Neo-Nazism: what is Germany's NSU terror trial?” DW News. www.dw.com/en/neo-nazism-what-is-germanys-nsu-terror-trial/a-39777036 accessed 10 January 2019.

Steinberger, A. (2012) "What we talk about when we talk about food: using food to teach history at the Tenement Museum", The Public Historian 34(2): 79-89.

Sutton, D. (2010) "Food and the senses", Annual Review of Anthropology 39: 209-23.

Waszak, S. (2018) "With WWII scars still raw, Poland tries to 'balance' its history”, Times of Israel. www.timesofisrael.com/with-wwii-scars-still-raw-poland-tries-to-balanceits-history/ accessed 10 January 2019.

Whitehead, C. (2016a) Why analyse museum display? http://cohere-ca.ncl.ac.uk/\#/ grid/56 accessed 10 January 2019.

Whitehead, C. (2016b) How to analyse museum display: script, text, narrative http://cohereca.ncl.ac.uk/\#/grid/76 accessed 10 January 2019. 
Whitehead, C., Eckersley, S. and Mason, R. (2012) Placing Migration in European Museums: Theoretical, Contextual and Methodological Foundations, Milan: Polimi Press. Žižek, S. (2008) In Defence of Lost Causes, London: Verso.

\section{Interviews}

Senior staff member (Anon. A) (2016). Beamish Open Air Museum, UK, interviewed by Christopher Whitehead.

Food operations senior staff member (Anon. B) (2016). Beamish Open Air Museum, UK, interviewed by Christopher Whitehead.

Elisabeth Tietmeyer, Director, Museum of European Cultures Berlin (2017, November). Interviewed by Susannah Eckersley. 
$\because$ Taylor \& Francis Taylor \& Francis Group

http://taylorandfrancis.com 
Part II

Contact zones and exchanges 
$\because$ Taylor \& Francis Taylor \& Francis Group

http://taylorandfrancis.com 


\title{
A taste for diversity
}

\author{
Massimo Montanari
}

\section{Introduction}

\section{Is there such a thing as a "European" cuisine?}

At first sight it would appear not. The variety of ingredients, styles of preparation and tastes typifying individual countries, and individual regions within them, bespeaks a gamut of cultures, episodes in history, attitudes and food preferences. Yet there is also an evident common identity distinguishing these differing cultures as one whole - above all to the outside eye - an identity akin to what you find inside each country: from the outside it seems stamped with one culture, but on closer inspection it proves highly differentiated. Europe as a whole is like that: great local, regional, national differences with a common heritage to share.

Somewhere between these two only apparently opposite poles lies the food culture of the Europeans, a major index of that identity and those differences.

\section{The medieval imprint}

The identity came into being with the birth of Europe and is hence a medieval creation. It stems from the encounter (first more of a collision, then a fecund integration) between different and largely opposing cultures: "Roman" - an amalgam in its turn of distinct cultures, to which Roman domination gave a unifying patina in the broad Mediterranean context - and "Barbarian" as the Romans, and the Greeks before them, called the Germanic and Slavic populations living on the fringe of their world. These too were a bundle of disparate traditions and cultures linked only by opposition to the Roman world. As they crossed, the two traditions (each already complex in its own right) gave rise to a medieval civilization that was neither Roman nor Barbarian but both together (Montanari 1994, 5 ff.).

At the dawn of the Middle Ages the clash between these cultures was partly a clash of food styles. The culture of bread, wine and oil symbolized agricultural Roman society (expressing man's ability to dominate nature, create landscapes 
and invent foods). Against it stood the culture of meat, beer and butter (symbols of Barbarian society, connected more to the forest than to the fields of agriculture). Little by little the two worlds blended and a "Roman-Barbarian" dietetic pattern emerged, perfectly reflecting what was happening in all fields of civil life, in social structure (as races mingled), institutions (with the rise of the so-called Romano-Barbarian kingdoms), law (Germanic customs being grafted onto the Roman legal tradition) and so forth. Ways of using the land and feeding practices likewise merged: agriculture got crossed with forest culture, giving rise to novel forms of coexistence between the two economies and to complex modes of production in which wheat, wine and vegetable cultivation rubbed shoulders with cattle ranging, hunting and gathering from the wild - distinct areas of production which were rated of similar importance at the time. The fascination of the old patterns (i.e. the Roman tradition) and the prestige of the new ruling class (mainly of Barbarian extraction) were the first vectors of that integration. It would end by giving the palm not to one, but to two key products, bread and meat. The resulting food system was dynamic and extremely creative. While Roman culture thought that bread was man's ideal staple - as a symbol, a pattern of production and a form of diet - and Barbarian culture gave that prominence to meat, a whole new medieval culture saw the systematic juxtaposition of "bread" and "meat" (in the most general sense: vegetable and animal produce) as the perfect diet.

\section{Food and Christianity}

The diffusion of Christianity played its part in this osmotic process (Montanari 1994, 15-21; 2015): first because it "promoted the image" of bread, wine and oil, symbols of the new faith; then the Church introduced the role of alternating between foods - the "fat" and the "lean" - according to the liturgical date or period. In Lent (and other periods or days of fasting) one was to abstain from meat and animal fats, eating cereals, vegetables and vegetable oils instead. There was also the equally binding custom - almost an obligation in its own right of solemnizing a feast by meat and lard (the same also applied to Carnival time). This transferred the cross-over of two dietary traditions onto the religious plane, and ensured the presence of all foods, fats and condiments on the tables of Christendom.

One kind of meat in particular, pork, would become the symbol of that Europe (Montanari 2015, 97-104), not just for economic purposes (herding swine was a prime way of using woodland), but for more cultural reasons as well. The pig was debarred from the Jewish and the Muslim tables: it was a perfect marker of Christian identity. The Jews had their own kind of "pork": the goose, which had pride of place in kosher cuisine, a true counterpart to the pig in culinary Christendom (Toaff 2011,55-71). With Islam - although present on the Iberian Peninsula - there was the physical barrier of the Mediterranean: beyond that marine frontier (no longer an internal lake, as under the Roman Empire) there was a ban on pork and also on wine. As a result, this typically "Mediterranean" 
product invented in the Middle East and spreading to the Greeks and Romans ended by being launched into the heart of the European continent, winning over many northerners who had traditionally drunk beer. Here again the role of Christianity was decisive in spreading a need and taste for a product which, like bread, was the sacred kernel of the new religion.

\section{Between cuisine and dietetics}

The same phenomenon of cultural integration which in the Middle Ages shaped a dietary identity common to Christian and Romano-Barbarian Europe can also be discerned in the culinary arts. The first thing to note is the evidence of a common dietetic culture behind that cuisine, based on the canons of scientific medicine dictated by Hippocrates in the fifth and fourth centuries BC and then erected into a system by Galen in the second and third centuries (Pucci Donati 2007). The techniques of cooking, matching meats with sauces, and the sequence of courses followed the rules of health repeated in all medical treatises of the age: how to combine the different "qualities" of foodstuffs (humid or dry, cold or hot) according to consumers' needs; how to offset one with another until an ideal equilibrium was achieved - such precepts merged directly or indirectly into ways of preparing food, making them "scientifically" consistent and standardized (Flandrin 1999a, 1999b; Montanari 2006, 51-7). For all the inevitable regional differences, Europe's recipe books of the 14th-15th centuries thus reveal a broadly circular pattern of ideas, a gastronomic koinè uniting the cultures of various lands by similarities of recipe, common terminology and affinity of tastes. Sweet and sour and sweet and salty are universally triumphant. So too with the use of spices (Laurioux 2005a), which followed the dietetic theories of the age (hymning their amazing digestive properties) as well as the dictates of prestige attaching to whoever could afford to grace his table with luxury powders from the Orient.

It was an "international" cuisine, then, but subject to infinite local variations (Flandrin 1984). Take "blancmange", for example: famed throughout medieval gastronomy and styled so for its all-white ingredients (rice, almond milk, breadcrumbs etc.), which might vary "on the fat side" or "on the lean side" (chicken breast in the former, fish or plain vegetables in the latter). But when recipes for blancmange were analysed from European cookery books (Italian, French, English and Catalonian), no one common ingredient was found among them (Flandrin 1984, 77-9).

\section{Europe and the Arabs}

Setting aside such "variants of philology", some major regional factors can be detected. Despite the "Christian" identity of the continent, Arabic influences are everywhere found in European gastronomy - even if historians do not agree on the actual importance to be ascribed to the Arabs in the redefinition of a European food model in the Middle Ages: some consider it fundamental 
(Rodinson 1949; Wilson 1981), others definitely downsize it (Laurioux 2005b; Rosenberger 1999). Its role was particularly strong in Mediterranean countries abutting on Islam - yet English medieval cuisine seems very sensitive to this influence (Hieatt 1997). Sicilian and Spanish cuisines betray an especially sweet tooth which connects beyond all doubt to the cane sugar the Arabs introduced wherever they invaded. Then again, a significant legend attributes the foundation of Salerno University - one of the hubs where medieval gastronomy and dietetics were forged - to a joint venture by four doctors: one Roman, one Greek, one Jewish and one Arabic (Montanari 1997, 371). The anecdote bespeaks the syncretism of medieval culture; it also shows a persisting area of "Mediterranean" culture surviving the Muslim occupation and overlapping with the "European" koinè mentioned earlier (Vitolo 2004).

\section{History and geography}

Obviously, it is not just Arab influence but also climate and local economy that explain the southern European propensity for foods and products with an exotic sound: citrus fruit, aubergines or spinach (and even more important food resources imported from the Arab world, such as rice, or the use of dried pasta). And although wine conquered the beer-drinking countries, that chiefly regarded the social elite: popular consumption stuck to the traditional beverage, for economic reasons no doubt, though taste will have played its part. This "alimentary geography" has partly remained down to our own times (Flandrin and Montanari 1999). Take that age-old drink, cider. It has kept its niche in the consumer market fairly unchanged since the Middle Ages: northern France and England. I mean that, despite some consumer standardization, local specialities do survive, above all among ordinary folk who are least affected by change and fashion. Take bread itself, which became Christian Europe's food par excellence, but has kept differing roles from one region to another: to the Mediterranean countries it has always been seen as a staple item and is still an automatic "must", served alongside cutlery in homes and restaurants; whereas in northern countries one has to ask for it, like any other food. The term companatico (i.e. the idea of something "to go with one's bread", bread being the staple, all the rest an accompaniment) has not become common coinage but is confined even lexically to the romance cultures, a case where the Roman heritage is palpable.

Meat-eating and the taste for meat again differ. Pork and beef are not appreciated to the same degree everywhere. This is partly due to simple economics, bound up with geography, soil and climate. Oak forests were traditional grazing grounds for pigs. They covered much of the European landscape but in some areas - especially the south, though also in the north - there was more open grazing land on which it was natural to raise sheep and oxen: almost exclusively sheep in the Middle Ages, cows from the 14th-15th centuries on and especially since the 18th-19th centuries (Montanari 1994, 71-8, 155-6). 
But there are other cultural, rather than economic, reasons explaining the pork-mutton divide and local preferences for one or the other. The pork culture always had a key role in the Germanic world (and earlier still among the Celts); sheep were the typical animals reared on Roman pastureland. One sees that it was partly different political and institutional backgrounds that dictated regional customs. Thus, even in present-day Italy there is a special fondness for the sheep in areas that avoided German penetration during the Middle Ages (or succumbed later, or more marginally), while the pig prevailed - possibly grafted onto previous native tradition - where the conquering tribes brought and spread their food culture. Take the case of a centre-north Italian region, Emilia-Romagna. Its double-barrelled name is due to its twofold history in the early Middle Ages. Emilia was occupied by "Barbarians" early on (the Lombards); Romania took its name (now written "Romagna") because it held out under the imperial control of Byzantium, the "new Rome". Even down to our own day the historical border between the two areas patently marks a gastronomic border too. The taste for mutton has not entered Emilia (save in a few traditional Byzantine enclaves) while it is typical of Romagna tradition. The contrast is found also in the way they stuff their tortellini (as they are called in Emilia) or cappelletti (the Romagna name): in both cases a flap of pastry, folded over a filling and cooked in broth. But the tortellino has a meat filling - nowadays varying, traditionally mainly pork; the cappelletto is stuffed with cheese - a milk product, originally from sheep (Montanari 2012, 41-3). This micro-historical fact, like so many others one could produce for many countries' gastronomic customs, is instructive in that it shows the extraordinary historical depths to which cooking traditions go back. In the ways of preparing food one glimpses a kind of "historical arrière-goutt", and one can easily imagine the range and richness of flavours produced by a complex strife-torn history like that of medieval and modern Europe. Behind every product, recipe or taste is a different history. The idea is gaining ground that such histories are a significant part of our cultural heritage.

\section{The grammar of food}

One realizes, in short, that victuals and recipes are not the fruit of an accident - or rather, they may be at the time of invention, but then it is environment and culture that underlie their continuing good fortune.Victuals and recipes take their place in a system (a geographical, economic, social, political, cultural or religious one), somewhat as words and rules make up a given language, a structure in which each element takes on a precise meaning and value. Against that structure and rule system we docket the exceptions, inventions and creations. That goes for language, and how true it is of cooking too (Lévi-Strauss 1958; Montanari 2006, 99-103). Every cuisine (like every language) is enriched by importations over time: far from being rigid and unchanging - though they are usually conservative - food 
systems evolve with time. They change and are continually reshaped. They pick up novelties with a mixture of diffidence and curiosity. They may adapt them to their own history, or they may be won over by them. Such was the case with American foodstuffs entering Europe in the 15th and 16th centuries (Montanari 2006, 105-3). It took a long time before maize, potatoes and tomatoes found a real footing in old-continent food habits. But from the 18th century on they had come to stay, basic to the Europeans' diet such that nowadays one could hardly imagine a Europe without them. What would a German table be without potatoes, or an Italian table without tomatoes?

The pattern by which American produce found its way into Europe is instructive. It shows that taste may form out of necessity: it was to combat hunger and to find an answer to the repeated 18th-century famines plaguing the people of Europe (who had outgrown their productive potential) that farmers overcame their suspicions of new produce which many deemed food for animals, and listened to the intellectuals hymning (and also hyping) its nutritional virtues. To boost adoption of the potato, many claimed that potato flour could be used to make bread - the Europeans' traditional fare, their food of all foods (Montanari 1994, 137-40). This proved an illusion, but the very idea suggests a tendency to incorporate novelties into one's culture, to make the unknown known, the different equal. Besides, when that attempt failed, many other imaginative ways were invented of making potatoes palatable. Some of those ways (like Italian gnocchi or French fries) trespassed on gastronomic ground that had been trodden for centuries in Europe. At all events, the potato muscled in on the European palate and has never since left it (Salaman 1985).

Similar attempts were made to channel maize into the mainstream of tradition - this time successfully (Montanari 1994,133-6). The Europeans - mainly in centre-south regions, while the potato spread in centre-north ones - used it to make polenta, a thick pap they had known for millennia, it being an age-old way of using cereals (millet especially, Italian millet or panico, and sorghum). These last named vanished from the fields and tables of Europe as maize came in. By the same token, potatoes scaled down the dietary role of turnips, which were a prime foodstuff in the Middle Ages. The two parallel stories illustrate the difficulty with which new foods are accepted, unless they come to occupy a specific place in the food system, perhaps ousting something else. In the same way the American turkey spectacularly took over from the peacock on the tables of European nobility, before becoming accessible to all at a period closer to our own day. Likewise, when Asian tea caught on in Europe, wine and beer consumption slumped under the new and formidable competitor (Montanari 1994, 126-7). This applied to social relaxation (having a drink together) as well as to the gastronomic and nutritional plane. As an accompaniment to mealtimes, either one drinks alcohol like wine or beer, or one takes an infusion like tea (as was and is the custom in many Eastern countries: it began to catch on in Holland and England from the 18th century on). 
The European fortunes of chocolate (Coe and Coe 1996, 104 ff.) again underwent "acclimatization". The natives of America drank it cold, unsweetened and spicy; Europe wanted it hot, sweet and bland, cutting the taste with the fatty addition of milk.

Then there is the story of the tomato (Gentilcore 2010), which likewise tied up with a form of cultural assimilation. It made a sporadic appearance in the 15 th and 16th centuries, but only really caught on at the end of the 17 th century, when it was turned into a sauce - that age-old gastronomic tradition which was virtually a "must" in medieval cooking (Adamson 2004; Scully 1995). In Spain tomato sauce went with meat; in Italy it blended happily with pasta - an early 19th-century experiment - lending a predominantly red colour to the latter, which had hitherto been white: butter and cheese had been its habitual condiments since the Middle Ages (Capatti and Montanari 2003, 54-5, 116).

\section{A revolution in taste (but not everywhere)}

Many a change thus took place in European eating habits across the modern era. It was not just to do with the produce (potatoes in the north of Europe, maize in the centre, tomatoes in the south), but a matter of taste. In the 17th and 18th centuries the medieval predilection for sweet and sour and spicy foods began to give way to gentler, more delicate flavours. Above all in France and (somewhat later) in Italy, haute cuisine explored new avenues, using simpler aromas instead of strong spices, introducing fatty oil- and butter-based sauces where medieval meat had called for clean, sharp, spicy tastes. The old gastronomic idea was based on the mingling of different flavours: typically the Middle Ages thought that food should tend to comprise all possible tastes, mixed and balanced by culinary alchemy ensuring a complete nutritional coverage (Montanari 2006, 61-6). By contrast the new cuisine decided that flavours should be distinct from one another, to be appreciated in separation. This "revolution in taste" (Pinkard 2009; Quellier 2004, 75 ff.), the daughter of Enlightenment rationalism, would affect culinary policy across the 19th and 20th centuries, but not to the same extent everywhere. Thus there was a marked persistence of "medieval" flavours in German and Eastern European cooking, above all popular: the sweet and sour contrast between strong-flavoured meat and fruit compote is a case in point. From the 18th century on, therefore, gastronomic variety increased across the continent.

\section{New religious contrasts, new forms of integration}

In the modern era other factors too deepened dietary differences across the regions of Europe. The Protestant Reformation played a large role (Montanari 2004, 110-16; 2015, 117-19). In Reformed countries it did away with Lenten fasting and outmoded the veneer of uniformity that had tended to standardize 
Christians' food habits during the Middle Ages, spreading the use of vegetable oils (instead of animal fats) across the north and enforcing a cut in meat eating (replaced by fish, cheese, eggs and vegetables). Having shaken off such restrictions, many Protestant regions reverted to their traditional ways, based heavily on meat consumption, as was the Germanic and Slavic wont - a cultural, not just economic preference, as we have said (Flandrin 1983). This, then, is the cultural and, as it were, ethnic (not just religious) drift of the treatises on free meat consumption that abounded in Protestant Europe across the 16th and 17th centuries; while the Catholic Church spawned treatises on "Lenten fare" listing in ever-greater detail the permitted or forbidden foods (Montanari 2004, 114). Unsurprisingly, those centuries witnessed a sharp drop in the fishery output in countries where consumption had been artificially boosted by the obligations of Lent; it only remained high in places like Holland, Scotland and Norway, where fish formed an obvious part of the daily diet (Michell 1977: 175).

While the Reformation marks a critical point in the sundering of Christian Europe, paradoxically it also prompted new forms of integration and cultural exchange. To take one example: at the dawn of the 17th century an Italian religious exile in London, Giacomo Castelvetro, wrote that "the noble English nation has learnt new dietary customs thanks to the influx of people fleeing to its safe asylum from the snares of the Roman inquisition". He himself composed a "small account on the roots, herbs and fruits eaten cooked or raw in Italy", a kind of panorama of Italian gastronomy taking one of its most original and distinctive features - the fondness for vegetables (Montanari 1994, 116). Castelvetro offered this to his English hosts so that they might come to appreciate "so many foods which many abstain from using, not knowing how to do so". When people circulate, ideas circulate. That is possibly the only advantage of enforced emigration. It may have been that very pamphlet by Castelvetro which, as the 17th century closed, prompted John Evelyn to publish the first English treatise on salads. Anyway, in the 17th century a new fondness for vegetables caught on in France (Quellier 2003, 2004, 81-3), possibly linked to the influence of Italian cooking.

\section{European culture in the face of globalization}

The trend towards standardizing consumption accelerated in the 20th century, partly through the increase in exchanges within Europe, and partly because of the multinationals controlling world markets. All Europeans today drink Coca-Cola and orange juice, and eat steak and chips (a symbol of transatlantic fast food after being invented by European genius in the 19th century). Everyone consumes pasta and rice, beer and wine (the former invading wine countries, the latter beer countries). White bread became the norm in most continental countries, only to see a curious revival at the turn of the 20th century of the fashion for brown bread (formerly a sign of 
peasant poverty). Again, the meat ration soared everywhere until the contraction of the latest generations, due to a new sensitivity to animals, the environment and health.

At all events, differences are still with us (Flandrin and Montanari 1999). The intake of meat is still lower in Mediterranean countries than further north. Every people has its favourite meat: beef and lamb in Britain, pork in Germany, veal in Italy. As for fish, although refrigerated trucks and lorries whisk it fresh to any destination, the Swiss and Austrians continue to eat much less than peoples by the sea. Again, while beer and wine are now to be found in all countries, how important each is continues to depend on local tradition. Potatoes are eaten in all areas, but the top consumers are still Ireland and Germany, the first countries where that became the staple diet.

What is more, when they turn up in different countries, foods and drinks are rarely identical. In Northern Europe the coffee sold is toasted far less than in Italy. Even Coca-Cola, symbol of the levelling of tastes, does not taste the same everywhere. Above all, the function of the various foods differs, and even when they are apparently very similar, so does the place they occupy on the menu and in the gastronomic system. Pasta is invariably a dish in its own right for the Italians, whether as a first course or a meal in itself, but in other countries it goes on appearing as a side dish to meat, which occurred in Italy during the Middle Ages and the Renaissance. The same goes for rice. Beer, which normally accompanies the meal in many northern countries, is a daily feature in Spain but not as a mealtime drink: it is served beforehand, along with appetizers prior to the rite of going to table (where wine is the rule). In Italy beer is now the drink to go with a pizza, but unlikely to appear with other dishes. Differences of the kind also apply to the degree of cooking. Italians eat their pasta much less "done" than is the rule across the continent; likewise with the juxtaposition of flavours (the medieval tradition of sauces is still flourishing in France and Belgium, but is less "in" elsewhere), with table etiquette or with the kind of crockery used. Wherever one turns, eating on the Old Continent preserves a wide range of local variants, tenacious differences of custom holding out against the standardization of behaviour. While patterns are tending to look similar, the uniformity is quite relative, and often more apparent than real, since the points in common are given a special slant by the culture of each country.

Such differences do not seem destined to disappear. Quite the reverse: the trend towards uniform behaviour is causing a reaction to set in (Montanari 2006, 83-9). People are getting more attached to their identity.

\section{The invention of regional cuisines}

This typically applies to regional cuisine, the mainstay of present-day gastronomy, though it has been given a far more modern cachet than we tend to imagine. For we like to place regionality in an "old world" context of food 
history, some mythical Eden, whereas it actually used to aspire to quite different values: medieval and renaissance gastronomy was not concerned with diversity but universalism (as we have said), cosmopolitanism, transcending the local dimension. In past centuries the cooking styles of the lower social orders were inevitably confined to what their own territory produced. That link, however, aroused no pride in group belonging; it was just seen as a limit, a restriction one sought to surmount. The prime aspiration of the elite, the main sign of privilege and social distinction, was a sophisticated cuisine putting together as many foods as possible on the table and glossing over the restrictive territorial identity. A 17th-century Italian chef, Bartolomeo Stefani, explains that a lord should not be straitjacketed by local limitations and not concern himself with seasonal produce since, with "a good purse and good steeds" (i.e. plenty of cash and fast means of transport) one can get hold of anything at any time of the year (Montanari 1994, 163-4).

To some extent it could be said that today's food industry has enabled the old wish to be fulfilled: it has given everybody - democratically if not disinterestedly - the chance to consume all and everything and cancel out regional differences. But that has triggered a reaction: the ardent and often scrappy quest for local eating traditions. "Rediscovery" of local cooking set in just as the food industry was smothering its right to a say. But at once the industry jumped on the bandwagon of the new demand. The image of "plain and simple" values of the past has been revived, and a fat price charged for them. The present situation - after much confusion and misunderstanding - is that regional cuisines form part of a common collective heritage about which we are much more aware (Montanari 2013, 65-71). Local dishes and foods in season have become prime values sought by every top chef and restaurant of repute. The traditional yardsticks of assessment have done a complete volte-face. This is the outcome of a metamorphosis in production processes which had seemed set on course to produce the exact opposite. But the paradox lies just there: in a truly fragmented world like the Middle Ages the aspiration was to create an artificial "universal" consumer pattern. In our own day's global village what counts is identity, difference, the genuinely local.

Let us be careful, then: praise of differences and defence of cultural identity are not some harking back to the past. They belong to the present and the future, coming from a recent conquest which is still in the process of consolidation. They belong here for another reason too: traditions are not given once and for all; they do not stem from some legendary "origin", but are created, moulded and gradually defined with the passing of time, as cultures happen to cross over, or to clash, overlap or merge (Montanari 2006, 133-7). At the dawn of the Middle Ages the encounter between Roman food habits and "Barbarian" customs brought great changes to both sides, without cancelling out the differences. The same occurred when Europeans came across imports from America. These were macro events: but there is also the daily story of 
little encounters, little discoveries and experiences going to form personal and group identities (Bruegel and Laurioux 2002; Campanini, Scholliers and Williot 2011).

Another example. We talk - too often inappropriately - of a "Mediterranean" diet as though a common geographical situation is enough to breed habits and customs in common. But how many "Mediterranean Diets" are there? And how many are truly Mediterranean? If you think of the ingredients that went to form them (American tomatoes, fruits and vegetables from Asia and Africa, pasta which first appeared in Sicily under the Arabs), there can only be one answer: there are no pure identities. Each is the upshot of contamination, each tradition is a daughter of history - and history never stands still (Montanari 2005).

These are topics of great relevance today, now that foodstuffs, like people, can travel faster than ever before. In the face of such phenomena history teaches that transformations are inevitable and it is vain to pine for the past - a past, let us remember, where famine was often the leading lady. Managing the relationship between present and past, tradition and change, is a task facing our own like previous generations. The starting assumption seems to be that diversity of taste, and a taste for diversity, are coded into the Europeans' chromosomes.

\section{References}

Adamson, M.Weiss (2004) Food in Medieval Times, Westport, CT-London: Greenwood. Bruegel, M. and Laurioux B. (eds) (2002) Histoire et identités alimentaires en Europe, Paris: Hachette.

Campanini, A., Scholliers, P. and Williot J.P. (eds) (2011) Manger en Europe. Patrimoines, échanges, identités, Bruxelles: Peter Lang.

Capatti, A. and Montanari, M. (2003) Italian Cuisine: A Cultural History, New York: Columbia University Press (La cucina italiana. Storia di una cultura, Roma-Bari: Laterza, 1999).

Coe, S.D. and Coe, M.D. (1996) The True History of Chocolate, London: Thames and Hudson.

Flandrin, J.L. (1983) "Le goût et la nécessité: réflexions sur l'usage des graisses dans les cuisines de l'Europe occidentale (XIVe-XVIII ${ }^{\mathrm{e}}$ siècles)", Annales ESC 33: 369-401.

Flandrin, J.L. (1984) "Internationalisme, nationalisme et régionalisme dans la cuisine des $\mathrm{XIV}^{\mathrm{e}}$ et $\mathrm{XV}^{\mathrm{e}}$ siècles: le témoignage des livres de cuisine", Manger et boire au Moyen Age, vol. 2. Nice: Les Belles Lettres, 75-91.

Flandrin, J.L. (1999a) "Seasoning, cooking and dietetics in the late Middle Ages", in J.L. Flandrin and M. Montanari (eds), Food: A Culinary History, New York: Columbia University Press, 313-27.

Flandrin, J.L. (1999b) "Dietary choices and culinary technique, 1500-1800", in J.L. Flandrin and M. Montanari (eds), Food: A Culinary History, New York: Columbia University Press, 403-17. 
Flandrin, J.L. and Montanari, M. (1999), “Today and tomorrow”, in J.L. Flandrin and M. Montanari (eds), Food: A Culinary History, New York: Columbia University Press, 548-53.

Gentilcore, D. (2010) Pomodoro! A History of the Tomato in Italy, New York: Columbia University Press.

Hieatt, C.B. (1997) "How Arabic traditions travelled to England”, in H. Walker (ed.), Food on the Move: Oxford Symposium on Food and Cookery 1996, Totnes: Prospect Books, 120-6.

Laurioux, B. (2005a) "De l'usage des épices dans l'alimentation médiévale”, Une histoire culinaire du Moyen Âge, Paris: Champion, 157-96.

Laurioux, B. (2005b), "Le goût médièval est-il arabe? À propos de la 'Saracen connection"”, Une histoire culinaire du Moyen Âge, Paris: Champion, 305-35.

Lévi-Strauss, C. (1958) Anthropologie structurale, Paris: Plon.

Michell, A.R. (1977) “The European fisheries in early modern Europe”, in E.E. Rich and C.H.Wilson (eds), The Cambridge Economic History of Europe, vol. 5, The Economic Organization of Early Modern Europe, Cambridge: Cambridge University Press.

Montanari, M. (1994) The Culture of Food, Oxford, UK-Cambridge, MA: Blackwell (La fame e l'abbondanza. Storia dell'alimentazione in Europa, Roma-Bari: Laterza, 1993).

Montanari, M. (1997) "I luoghi della cultura alimentare", Centri di produzione della cultura nel Mezzogiorno normanno-svevo, Bari: Dedalo, 355-72.

Montanari, M. (2005) "Continuidad y rupturas, incorporaciones, diversificaciones en la época medieval y la era moderna”, in J. Contreras, A. Riera and F. Xavier Medina (eds), Sabores del Mediterráneo. Aportaciones para promover un patrimonio alimentario común, Barcelona: IEMed, 122-30.

Montanari, M. (2006) Food Is Culture, New York: Columbia University Press (Il cibo come cultura, Roma-Bari: Laterza, 2004).

Montanari, M. (2012) Let the Meatballs Rest, and Other Stories about Food and Culture, New York: Columbia University Press (Il riposo della polpetta e altre storie intorno al cibo, Roma-Bari, Laterza, 2009).

Montanari, M. (2013) Italian Identity in the Kitchen, or Food and the Nation, New York: Columbia University Press (L'identità italiana in cucina, Roma-Bari: Laterza, 2010).

Montanari, M. (2015) Mangiare da cristiani. Diete, digiuni, banchetti. Storie di una cultura, Milano: Rizzoli.

Pinkard, S. (2009) A Revolution in Taste. The Rise of French Cuisine, Cambridge: Cambridge University Press.

Pucci Donati, F. (2007) Dieta, salute, calendari. Dal regime stagionale antico ai regimina mensium medievali: origine di un genere nella letteratura medica occidentale, Spoleto: Centro italiano di studi sull'alto Medioevo.

Quellier, F. (2003) Des fruits et des hommes. L'arboriculture fruitière en Île de France (vers 1600-vers 1800), Rennes: Presses Universitaires de Rennes.

Quellier, F. (2004) La table des Français. Une histoire culturelle (XVe-début XIX ${ }^{e}$ siècle), Rennes: Presses Universitaires de Rennes.

Rodinson, M. (1949) "Recherches sur des documents arabes relatifs à la cuisine", Revue des études islamiques 17: 95-165.

Rosenberger, P. (1999) "Arab cuisine and its contribution to European culture", in J.L. Flandrin and M. Montanari (eds), Food: A Culinary History, New York: Columbia University Press, 207-23. 
Salaman, R.N. (1985) The History and Social Influence of the Potato, Cambridge: Cambridge University Press.

Scully, T. (1995) The Art of Cookery in the Middle Ages, Woodbridge: Boydell.

Toaff, A. (2011) Mangiare alla giudia. Cucine ebraiche dal Rinascimento all'età moderna, 2nd edn. Bologna: Il Mulino.

Vitolo, G. (2004) "La Scuola medica salernitana come metafora della storia del Mezzogiorno", Studi storici 45(3): 633-50.

Wilson, C.A. (1981) "The Saracen connection: Arab cuisine and the medieval West", Petit Propos Culinaires 7: 13-22; 8: 19-28. 


\title{
Chapter 8
}

\section{Franz Joseph's Tafelspitz \\ Austro-Hungarian cooking as an imperial project}

\author{
Catherine Horel
}

\section{Hybridism and transformation in a multinational empire}

The issue of European culinary heritage is certainly not an easy one. However, in the 19th century, in spite of the birth of new gastronomic nationalisms, it is essential to consider the prominent role of empires in transfer and exchanges, as well as in the construction of a shared patrimoine. This chapter focuses on the Austro-Hungarian Empire. Food and gastronomy travelled from one end of the empire to the other. Thanks to the customs union of the monarchy and the common currency, products and people circulated without restriction. Cattle, wine, grain etc. formed the basic elements of Habsburg cuisine's cultural heritage. Civil servants, officers and academics came back from their various postings with changed tastes: their wives had to adapt not only to the foreign language spoken by the cook, but also to her cuisine and to the ingredients offered in the marketplace. Books were written for them that gathered together all the diversity of "Habsburg" cuisine. The vocabulary bears witness to these transfers: many words for ingredients, such as vegetables, are typical "Habsburg" constructions, which were at the core of European gastronomic identity. When asking questions about European cultural heritage, and discussing issues such as hybridism, it is first of all crucial to rethink the multinational perspective within the empire's history.

The multinational Habsburg Empire embodies hybridism through multiple identities (ethnicity, language, confession), mobility and exchanges. In its various territories there is a translation and integration of culinary traditions from the centre(s) to the peripheries.

The multinational empire not only adapted and adopted Ottoman and Italian recipes: they became symbols of a "Gemütlichkeit" (or cosiness) all its own: coffee of every possible variety, Strudel (sweet and salty) and Fisolen, together with wines grown in many regions of the kingdom. Food and gastronomy travelled from one end of the empire to the other. From the mid19th century on, increased mobility helped not only to transport food, but also to enable people to travel for work, study or leisure to places where they 
encountered other cooking practices and products. The Czech maidservants coming to Vienna made Bohemian cuisine a characteristic of the capital's gastronomy. Railways were built together with demonstrative train stations where the restaurant was instrumental in transferring recipes: thus Hungarian gulyás soup travelled east and west, turning into a beef stew.

Thanks to the customs union of the monarchy and the common currency, products circulated without restriction, while newspapers all over the empire advertised the same products in all languages, thus creating a common world of culinary references. The result is that many recipes were absorbed into "Viennese" cuisine, and many influences were adapted or imported, some dating back to the 16 th century. Vienna was thus a melting pot in the first sense of the word, where foreign (Italy, France) and local (Alpine lands, Bohemia, Hungary) contributions were mixed. A patchwork from all the Habsburg provinces and hereditary lands was created and offered in the capital's restaurants (Beisln), though far from corresponding with some alleged Austrian cuisine (Breuss 2003). Hybridism and transformation characterized this phenomenon. Legends and myths were invented to explain these transfers - the most famous being the Wiener Schnitzel- so that we may truly speak of "invention of tradition" (Hobsbawm and Ranger 1983) to describe the palimpsest that was Viennese cuisine. Different geographical origins got attached to the same recipes, while the same names, rudely translated, travelled from one linguistic environment (German, Slavic, Latin-Italian, Turkish,Yiddish) to another and were appropriated, causing endless battles over the origin of a dish. In the broad regions of this continent-wide empire, consuming dishes that bore the stamp of faraway places (Bucovina, Dalmatia) became a matter of internal exoticism (Binnenexotik). After the dissolution of the Austro-Hungarian state the recipes became a lieu de mémoire (Nora 1984), turning Viennese cuisine into a witness to the many tastes of the empire where everybody contributed to the proliferating diversity: migrating peasants and workers, domestics and cooks, soldiers, civil servants and aristocrats. But what remained of this transfer outside Vienna? Was the Viennese melting pot exported? In short, though one could find the cuisine of the whole empire there, were these recipes exported to other places? Was it possible to eat Bohemian cuisine in Sarajevo, or paprika in Trieste? It seems here that the difference is mainly between urban and rural environments: peasants in Galicia went on cooking as they had been taught; creativity, fantasy and curiosity were mainly urban attributes, if only because diversity was at hand.

The everyday agents in spreading cooking practices were the people of the empire, themselves on the move but meanwhile transporting products. Cooking played a role in the formation of national identity through both appropriation and differentiation. Hoteliers and cooks were essential actors in this process of transfer, some even writing their own cookbooks. Here as anywhere, there was a gendered division of the profession: in domestic households (though less so in aristocratic houses) the cook was a woman, whereas in hotels and 
restaurants it was a man. On the other hand, most authors of cookbooks were bourgeois women bent on sharing their skills and advice on how to cook (or train the cook) and to conduct a perfect household. Migrants, generally coming from rural parts, brought their culinary traditions but had to adapt to the availability and price of ingredients so that they necessarily changed some of their recipes and took over others from the new environment; in return they inspired their neighbours. In the courtyards of Vienna, Prague and Budapest the Pawlatschen, kitchens, opened onto the corridors so that everyone would hear, smell and sometimes taste what the neighbour was cooking. Thus diversity was an everyday experience over the kitchen stove.

With its continental expansion, the Habsburg Empire encompassed regions producing everything needed to feed the population, except colonial and overseas exotic products that had to be imported almost exclusively through its two main ports: Trieste for the Austrian part of the monarchy, Fiume for the Hungarian one. From the end of the 1850s extension of the Südbahn (southern railway) led to quicker and more widespread exportation of these goods. However, the empire knew transfers of products and practices well before the 19th century. The addition of the so-called Kronländer (hereditary lands) changed the food circuits: provinces were not only political assets, but also food reservoirs and a way to diversify production. Thus traditions were created: product provenance tied up with a land or province, and the image of each land was accompanied by its most famous food or wine products. The cult of food diversity throughout the empire culminated in the series Die österreichisch-ungarische Monarchie in Wort und Bild, where each territory was depicted and its value enhanced by mention of its agricultural produce (Zintzen 1999). The customs union and common currency that was reinforced by the 1867 Compromise with Hungary engendered a free market.

The Habsburg Empire encompassed many cultural borders (Catholicism/ Protestantism, Roman Catholicism/Orthodoxy and Latin, German, Hungarian and Slavic populations, as well as Jews and Muslims), one of which is rarely mentioned: the divide between beer and wine, present in both parts of the empire, though the Hungarian part belonged mainly to the "wine" region. The frontier stretched from Moravia in the north to a point west of Salzburg in the west. This does not mean that beer was not brewed elsewhere, but that it was then in competition with wine. The Kältetechnik invented by Anton Dreher in the 1870 s enabled one to refrigerate and consequently to transport beer all over the monarchy (Tötschinger 1996). Dreher created Lager-Bier, and the process was soon imitated by others. Beer rapidly became one of the first broadly distributed food products, and was widely advertised in Biergarten and restaurants. With the creation of many local breweries, beer was no longer seen as a "German" drink: in Hungary in particular, the negative perception of beer originating with the repression of the 1848 revolution was reversed as soon as local entrepreneurs started to produce beer, though Dreher's beer was still available and popular. The most famous brands were brewed in Bohemia: among 


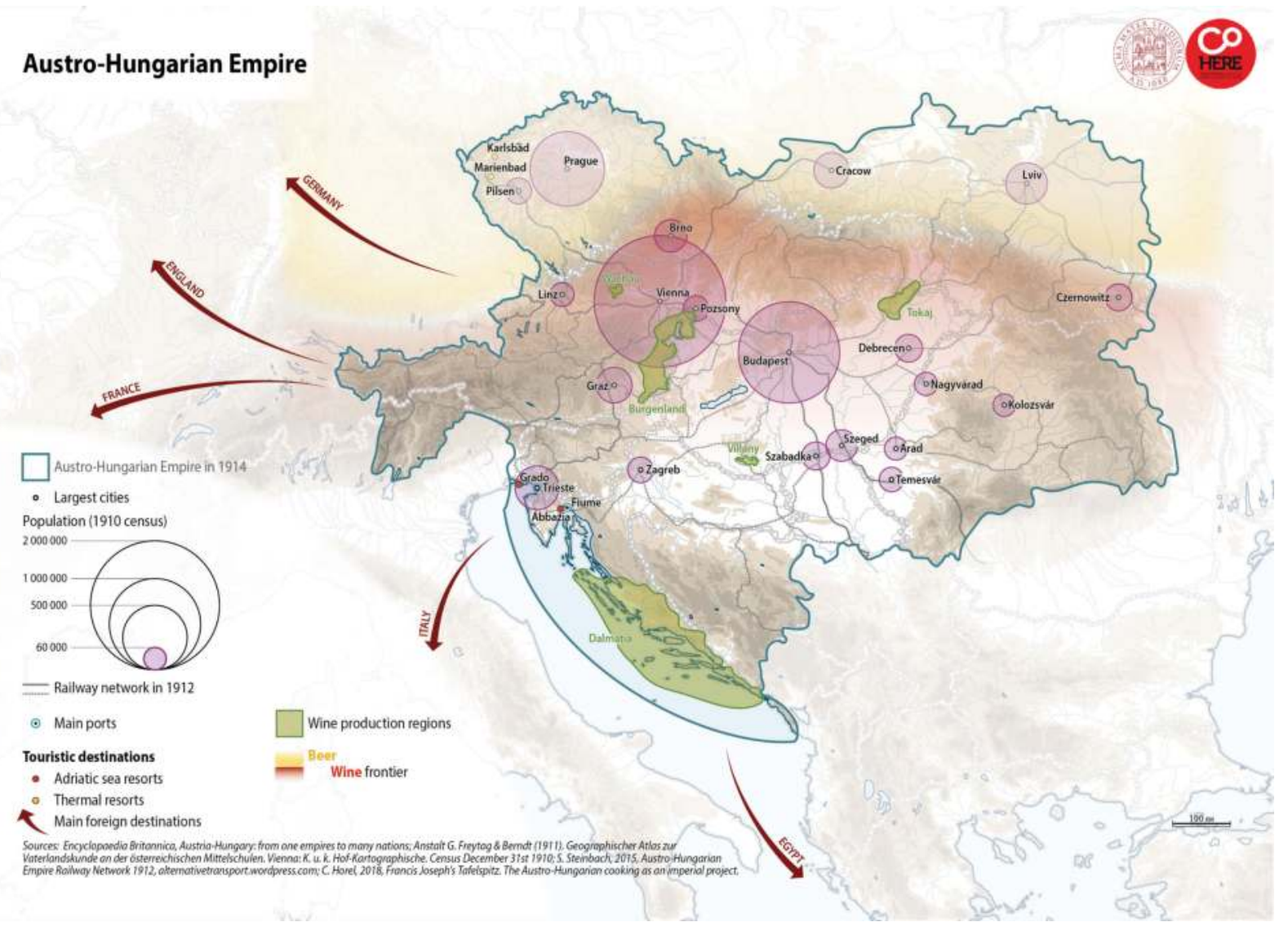

Figure 8.I Austro-Hungarian Empire 
them Pils in the city of Pilsen (Plzeň). Austro-Hungarian brewers had a reputation for excellence and went on to open breweries outside the monarchy, beginning with the "colonial" experiment in Bosnia-Herzegovina. In this way a large and representative brewery became established (and still exists) in Sarajevo.

For export purposes, Hungarian wine was praised, building on a legacy of famous Tokaj - "Vinum regum, rex vinorum"- and others, mainly from Transdanubia. The other wine region that acquired a reputation for plenty and excellence was Dalmatia, as soon as this province fell into Habsburg possession after Venice lost its foothold on the Adriatic coast at the turn of the 19th century. Thanks to the Südbahn as well as the opening of big warehouses and storage facilities in Trieste and Fiume, Dalmatian wines soon flowed throughout the empire. Local newspapers advertised the arrival of these wines. With the acquisition of the Küstenland (littoral) the empire greatly extended its maritime capacity beyond Trieste and Fiume so that not only wines, but also other products became available. It was then possible to send fish and some other seafood to elite customers in Vienna and Budapest, where people had been used to freshwater fish. It became a commoner item in the diet of locals and tourists who started to visit the Adriatic sea resorts like Abbazia or to go on vacation along the coast to Zara (Zadar), Spalato (Split) or Ragusa (Dubrovnik). But of course the most famous Austro-Hungarian fish was the carp, traditionally prepared for religious celebrations such as Christmas Eve, thus becoming a transnational dish, whether in its Jewish form (gefillte Fisch), in soup by Hungarians or in a paprika sauce by Serbs (serbischer Karpfen). The big rivers, the Danube, Drava, Sava, Tisza and many smaller ones, provided a great variety of fish that were and still are prepared in more or less the same way.

Yet the majority of the population was rural, and agriculture was the main resource of the empire. Hungary was the major purveyor of grain and mills for a long time formed the skyline of Budapest. It was also one of the main producers of cattle and pork: the arrival of herds in Vienna was a common sight, bringing a touch of exoticism with herdsmen in traditional garb. These men were called gulyásokin Hungarian: the famous soup that was to become one of the most renowned dishes in the empire derives from this name. It combines two of Hungary's main products, beef and paprika.

\section{Cities and marketplaces}

Transfers occurred in the cities, not in villages where people maintained their cooking traditions, and people did not buy "exotic" products from the next market town, first because they were expensive, and second, because they did not feel curiosity to try them. Yet urbanization drew more and more peasants into cities of all sizes: from the neighbouring provincial centre to the metropolises of Vienna and Budapest. In the medium-sized cities commerce developed so that more shops were able to sell goods not originating from the immediate 
countryside: the advertisements in the local press show that the same products, sometimes with names translated, were available throughout the empire.

The bigger the city, the broader the scope for tasting products or meeting people from other regions. Trieste was considered Volkstopf, a melting pot of people where influences and food from various regions and overseas passed through or were consumed on the spot. The diverse populations who had gathered there under Habsburg rule since 1382 helped to create a mixed heritage. Trieste was one of the doors through which Italian influences came to Austria but not the only one, for the Habsburg dynasty also controlled Lombardy and Venetia. Here transfers had a long history of reciprocity and a tradition of inventiveness. The proximity of Moravia and even Bohemia to Vienna, enhanced by the early development of the railway for economic reasons, drew migrants to the capital and created the figure of the "Czech" cook. The same could be said for the Slovene cook in Trieste, originating from the villages of the hinterland around the city. Mixed regions such as Banat or Bucovina have an extraordinarily rich cooking tradition that is the result of exchanges in the marketplace, but also mixed marriages, common Christian festivities and some transfers from Jewish cooking practices as well. As for Bucovina, a glance at the map shows the roads along which influences could arrive. A late acquisition by the monarchy at the end of the 18th century, Bucovina had Ukrainian (Ruthenian), Polish, Armenian, Jewish, Hungarian and Romanian populations as well as some German settlers: this created not only a Babel of languages, but also a melting pot of food. Here as in the southern part of the kingdom (Vojvodina, Transylvania), corn replaced potatoes as one of the staples of cooking (Jaworski 2014). Just as there is no "Viennese" cuisine, so there is no longer a Bucovinian cuisine, for each recipe is more or less the result of mixed influence, adaptation and transformation, if not translation (Weidhofer, BanlerBachyńska and Meindl 2010). This also had the result of creating disputes over the "national" attribution of certain dishes. Border zones and regions situated on the fringe inevitably developed a mixed cooking culture that was chiefly found in towns, thanks to the multiplication of hotels and restaurants, and to the growing supply of products.

Under the Habsburg monarchy the marketplace embodied diversity: since many regions were multilingual and multidenominational, it was an opportunity to exchange goods and practices. The products of a region were shared by everyone, but the way they were consumed differed from one people or faith to another. In the bigger cities, the marketplace was transformed at the end of the 19th century into a market hall, visited by servants, bourgeois and professional cooks, while the surrounding square still attracted street vendors. But most of the time there was no such hall and customers were forced to buy out of doors.Vendors generally came from nearby villages, only the annual market the Jahrmarkt, a term that was exported as far as Russia - attracting merchants from farther afield. In many of these towns, where the hinterland was peopled 
by a minority group such as Slovenes around Trieste, or Czechs in Prague and Brün/Brno, the language spoken at the market was often mixed.

Everyday life and the pragmatism of both shopkeepers and customers showed that despite nationalistic propaganda, people went about business as usual and took no notice of the linguistic divide in towns. The market was a place where multilingualism remained at its highest level because of the presence of peasants and merchants from the region and sometimes from further destinations. Merchants and visitors flocked from far away to the yearly fairs. Many peasants had a very poor knowledge of a second language, and therefore customers would address them in their mother tongue, thus showing that they also knew the basic vocabulary of the minority. As the market customers were mainly ladies and maids, they were accused by nationalist activists of deviant behaviour in not insisting on speaking their own language. An example of this occurred at the famous Krautmarkt (cabbage market) in Brünn. The German nationalist weekly Brünner Wochenblatt inveighed against German ladies who "completely lack national upbringing" because they speak Czech at the market, even to German peasant women (Brünner Wochenblatt 1905)! It should be an absolute rule for German ladies and girls to speak German to everybody, argued the journalist, who was, needless to say, a man. Indeed, women showed "indifference" to nationalistic principles and were thus a target for (men's) propaganda of the kind mainly expressed in newspapers. The fact is that people were multilingual and adapted their linguistic practices without necessarily associating them with national identity. They did the same with food when confronted with dishes that were not the same or not prepared as they were used to at home.

\section{Mobility}

In bigger towns the main source of changing habits was the railway. Of course, people had already been mobile in the empire for various reasons (the army, studies and careers), but the railway made movement easier and cheaper, it reduced the distance to the nearby provincial centre and it also let people travel to the bigger cities. ${ }^{1}$ Introduction of generalized military service took young peasants who had never left their villages to the other end of the empire, while in their regiments they were confronted with comrades speaking other languages. Army cooks - there is no real study about them, but many of them are said to have been Hungarians - gave "Habsburg" cooking a personal note depending on their own place of origin. Officers from various areas also contributed to this diversity, as did their aides-de-camp by introducing new recipes. In medium-sized towns the railway station restaurant was one of the places where "Viennese" cuisine might be offered. As the door to the outside world, this restaurant had to provide well-known local dishes so as not to alienate the local customers, but also had to give a whiff of the capital by serving "exotic" food, which here meant "inner-exotic". There was thus nothing extraordinary about finding Dalmatian wine in Bucovina. Thanks to the extensive railway network 
and soon also to new conservation and refrigeration techniques, a hotelier in Pressburg (Poszony) could order fish from the Adriatic at only a moderate risk.

Later on, the new urban middle classes were increasingly interested in novel kinds of taste. The older noble elites had experienced cooks in their estates or townhouses, but the bourgeois often had only one servant who was not always a good cook and who probably had a limited repertoire of dishes. Yet even in these medium-sized towns the cook might come from a village belonging to another nationality (a Romanian might be cook to a German or Hungarian family in Temesvár for example, or a Slovene to a German or Italian family in Trieste) and thus introduce her own cooking practices whilst at the same time adapting to what the family expected. We know from memoirs that many Jewish households had non-Jewish cooks whom they instructed about the kosher rules (Koerner 2004).

In the last decades of the 19th century the main cafe-restaurants of a city had to offer something else to their customers. Such places flourished everywhere, bearing names like the "Habsburg", "Kaiser von Österreich", "Central”, "Imperial", "Wien" etc. Along with their names they brought the diffusion of Austro-Hungarian imperial culture; the inhabitants of remote border towns had the impression that the capital had come nearer to them, at least in the symbolic form of coffee specialities, Strudel variations and Wiener Schnitzel. Diversity of menu was matched by the range of newspapers available in the cafe, a sign of its opening up to the world. All new hotels built in those years bowed to this transformation of urban planning by being appointed with a restaurant, and likewise theatres began to include a café offering snacks and a light supper. New beerhalls were also opened, sometimes in the outskirts or in the new parks or in the nearby "forest" to accommodate weekend customers. Even in the more modest taverns, a fashion for new types of food found its way. This was often due to the fact that the innkeeper hailed from another region, if not further afield. In many towns outside Austria proper, German was still a leading language so that it was possible for an adventurous soul from Graz, for example, to try his luck as far as Czernowitz or Temesvár, where he would in the course of a few years learn the other language(s) through his staff and/or local wife. There are many examples of such "careers". Advertising for anew innkeeper was frequent in the press, and sometimes his origin might be mentioned as a proof of quality and exoticism. If a Czech brewer came to Sarajevo, people would welcome the event, assuming he knew something about beer. In Sarajevo a brewery was anyway an immediate success and also a political statement in a city where Muslims were still in the majority. While beerhalls advertised their range of Czech beers, the food industry in turn started to produce "chemical" drinks out of sugar beet, like rum, which had nothing to do with the real product but was, next to beer, the cheapest alcohol available to the lower classes. It became the typical drink of coach drivers (Fiaker) all over the realm. When wine was too expensive or not produced in the region, ordinary people resorted to Schnaps (and local names thereof) for a quick "binge". But this was 
more a phenomenon of the countryside, where practically everyone distilled his own Schnaps; in other cases it was consumed and bought at the local inn, generally run by a Jew. This led to the common taunt by anti-Semites that Jews were "perverting" the villagers by tempting them with alcohol. Actually many distilleries were founded by Jews who had long been stewards on estates; they were not permitted to buy land until the mid-19th century, but they had developed skill in managing others' lands and were consequently among the pioneers of the food industry. ${ }^{2}$

Mobility meant travelling for professional reasons (migration, study, military service, civil administration), but also for leisure, which started to be a mass phenomenon. Thanks to the extension of the railway, travel times and costs were reduced so that more people could afford to go to spas or to the seaside; the wealthy would also go abroad (Italy mainly, Egypt, Germany, France and England). There they expected social encounters, leisure, comfort and, last but not least, gastronomy. Those who chose the seaside would certainly have their first taste of seafood and fish, sometimes even oysters and hummer. In eating such things they experienced the territorial extent of the monarchy, exoticism within their own country. ${ }^{3}$ Certainly spas could not compete in this respect, but they were in their way places of gastronomic experiment: the most famous were located in Bohemia (Karlsbad/Karlovy Vary, Marienbad/ Mariánské Lázně, Franzensbad/Frantyškovy Lázně), but there were others in today's Slovakia, Slovenia and Croatia. There too new hotels and restaurants sprang up where hoteliers provided Austro-Hungarian cuisine so that everybody would feel in Vienna and at home at one and the same time. An exclusive and exotic touch was introduced through French recipes and wines (real champagne, for example). To simulate French champagne, sparkling wine was imported from Italy, though it was also produced within the kingdom by firms that had a transnational reputation, the best examples being Schlumberger in Vienna (founded 1842) and Törley in Budapest (founded 1882). Both sent their wines throughout the empire, and their advertising was omnipresent in the press, on street billboards and in cafés.

Diversity of taste was brought about by cooks who adapted and interpreted the recipes they had learned or discovered in their travels. This profession, together with many others, was a highly mobile one. The domestic cook in smaller towns, as previously mentioned, generally came from the neighbouring countryside, but in bigger towns she may have travelled from further away. In Vienna, most immigrants came from Moravia and Bohemia, the majority of the women becoming servants in bourgeois households, where they were also responsible for the cooking (together with bringing up children). ${ }^{4}$ They brought to Viennese gastronomy its most renowned features (Schwendter 1995): Buchteln (original Czech brioche buchta), Powidl (a sort of plum stew, very sticky, also appropriated by Poles under the name powidta) and, finally, knedliky (knödel), though here we have a real transnational transfer: as soon as people began to prepare dough, they redeveloped such 
recipes as gnocchi, quenelles etc., marked by substantial differences (the filling, the dough texture, whether it was made of bread or potato). Going down to the south, the knödel turns into pasta (Slovenia, Italian provinces) and eastwards into small dough for soup (galuska in Hungary), ravioli (Polish pierogi or Ukrainian varenyky), or it stands alone with cheese and other ingredients (Slovak halusk $k$ ). Confronted with such novelties, the housewife might try to instruct the cook in other traditions, sometimes her own if she originated from another non-German region, or get her to use one of the cookbooks that were widely produced at the turn of the century. Thus meals resulted in a combination of the cook's own flair tempered by the needs of a bourgeois household: when the household was wealthy, the cook was expected to prepare formal dinners and receptions at which she could not serve "peasant" food. On such occasions she was sometimes allowed to recruit helpers which she invariably found among her acquaintances or relatives, in short, belonging to the same national group.

Slovene maids and cooks had a similar influence in Trieste with the difference that the local cuisine was already a mixture of Italian and south Slavic with interchangeable names. It was a more disturbing prospect for a cook coming from a remote hinterland village to have to handle seafood which she was not used to. Cooks and maids, as well as women from the lower classes, communicated through the already-mentioned Pawlatsche and met in the outside corridor, which was equipped on each floor with a washbowl called a Bassena. There they would discuss cooking, among other gossip, and hence the Viennese word Bassenatratsch. Thus the taste for diversity transcended all classes and created a heritage common to all Austro-Hungarian cuisine that is still perceptible today.

\section{Inventing the tradition of Viennese cuisine}

Habsburg cuisine was a palimpsest on which everyone added his/her own heritage of cooking practices and references. What now goes under the name of "Viennese" cuisine was not formulated as such before 1918, or rarely (Neuber 1987). Along with nostalgia for the Habsburg monarchy's multiculturalism, its culinary tradition has turned into a lieu de mémoire (Csáky and Lack 2014). Vienna influenced the whole empire; it exported the Kaffeehaus and many cultural habits linked to food consumption, but its cooking was itself a conglomerate of influences. So the transfer here really goes in both directions. Viennese inspiration lay behind the proliferation of hotels and restaurants adorned with imperial names: this extended as far as Galicia, Bucovina and Bosnia-Herzegovina. The civilization of the Kaffeehaus reached from one end of the empire to the other (Kurdiovsky 2012): each town had its famous place where people met (more and more women daring to visit them on their own), worked and ate simple dishes (Gulaschsuppe, Schnitzel, Palatschinken, all possible variants of Strudel). Yet the content of the dishes reflected the Volkstopf that 
was cooked in the capital of the empire: Italian, Czech, Alpine-German and Hungarian.

The first indication of these exchanges of diversity is the names used for ingredients and recipes; in their Austrian version they are now seen as "typical" of the old monarchy because they are different from the ones used in Germany proper. They go to form the Austrian identity, but are in reality inherited from other languages (Danielczyk and Peter 2014).Vienna's main market, the Naschmarkt, was (and still is) the meeting place for these Austro-Hungarian products converging from all over the realm. Words and their culinary implications travelled throughout the empire: a good example of this occurred with the occupation of Bosnia and Herzegovina in 1878: Austrian vocabulary began to spread in all fields, mainly military (a logical consequence of the occupation), but also in gastronomy with the arrival of hoteliers from Austria (most of them Czechs and Croats who handled Serbo-Croatian better) and Hungary (here again, Serbs and Croats). They introduced Austro-Hungarian tastes which were then combined with traditional Turkish-Balkan specialities.

Gastronomy was not exempt from nationalistic quarrels, as in this example from Trieste. The newspaper Slovenka (The Slovene Women) had a column dedicated to "pure Slovene". It is a series written as a dictionary where the authors explain the etymology of foreign words that have penetrated the Slovene language; they suggest replacing them with more "original" terms which they are sometimes forced to create ex nihilo. They also chafe against the use of dialect. For example the melspajz from the Austrian Mehlspeise (a category of dessert made with flour) should be renamed testenina. Concerning Italianisms, makaroni noodles must be changed into the supposedly more autochthonous vlitki (Slovenka 1897). Zagreb hoteliers writing their menus with German and/ or Hungarian names were attacked by the press for not being conscious of their national duties, especially when they were not considered "pure" Croats. Ines Sabotic shows that the language in which menus were written was not considered a relevant issue before the 1900s. And even then standardization stemmed from the legalism of the city authorities and not nationalism (Sabotic 2004). Yet the hoteliers were reluctant and slow to introduce still imprecise Croatian terminology: German names prevailed that everyone understood. Indeed many hoteliers and restaurateurs were of German origin. Finally the solution of bilingual menus was adopted. Nationalism also interfered with recipes, proclaiming them to be "original"; some of these disputes are still raging today over the "invention" of such and such a dish.

Thus it was not irrelevant to call Viennese cooks the mediators between nationalities because their pragmatism and ability to adapt had nothing to do with linguistic groups (Köstlin 2014). Just as Die österreichisch-ungarische Monarchie in Wort und Bild demonstrated the ethnographical diversity of the monarchy, so Viennese cuisine reflected the various heritages that came to symbolize it. As the author (we haven't introduced him yet!)himself puts it: "in der Wiener Küche tanzt aber ein ganzes Ensemble" (Köstlin 2014, 121). The 
variety of dishes offered in Viennese cafés and restaurants reflected this Volkstopf, though with some nuances as to the social level of the place or its pretensions. From the Beisl around the corner to the Sacher Hotel, from the Heurigen in Grinzing to the exclusive Demel pastry shop, one could find more or less the same things. This would have been impossible in Paris, for example. Names and terminology travelled as well, sometimes with the names varying widely from one cookbook to another. Linguistic transfer functioned throughout the empire (Pohl 2007): Italian (frittata, risotto, fagioli), Hungarian (gulyás, palacsinta), Slavic,Yiddish and Turkish names were more or less accurately translated before being incorporated into Viennese gastronomy beyond recognition so that their original variants are sometimes forgotten or rediscovered. This form of appropriation - not only by Viennese cooks - creates battles over the "nationality" of a dish. It also forms a specific German-Viennese vocabulary that stands apart from common German and puzzles foreigners (beginning with Germans) (Pohl 2007, 32-5).

Even at theVienna court, simple dishes were cooked for everyday meals: Franz Joseph was proverbially fond of Tafelspitz (soured boiled rump of beef) and was imitated in that on Sundays by some of his devoted subjects, as narrated by Joseph Roth in his Radetzky-March (Roth 1986). For this Fräulein Hirschwitz, the housekeeper, probably needed no instruction or a glance in a cookbook, so integrated was the dish in the cooking traditions of Austria. It was common knowledge that the emperor and king liked Tafelspitz, but also that when he was enjoying his summer vacation at Bad Ischl he was a client of the Zauner pastry shop, which had been made a court provider (k.u.k. Hofzuckerbäcker), a distinction reserved for Demelin Vienna and few others. His lady friend Katharina Schratt used to come to Ischl as well, and among the guests at her villa was Franz Joseph. She wrote her own cookbook (Povse and Maurer 2012).

\section{Chefs and cookbooks}

All in all, though, the court was not really a gourmet's haven, and it was elsewhere that chefs made big reputations and created a tradition of gastronomy. The best examples come from Hungary thanks to the confectioners Kugler and Gerbeaud (who was a Swiss), and the chef Károly Gundel. They established the fame of Hungarian cuisine, which, together with the excellence of its wines, became a benchmark for the monarchy. Gundel was one of the first chefs to publish his own book of recipes (Gundel 1988). He ran the restaurant of that name in the Budapest City Park (Városliget). These works were also masterpieces of the Austro-Hungarian pastry tradition that is still well represented today. Géza Kugler published his own recipe book, most of which is devoted exclusively to this sweet form of art. ${ }^{5}$ Interestingly, the savoury recipes are all translated into French (not very accurately, be it said), but not the sweet ones, which were considered indigenous, conferring some form of specificity on the Konditor (cukrászat in Hungarian). Maybe this cult for cakes, cream and confectionery 
of all kinds lies in the baroque tradition of specifically Austrian Catholic piety (pietas austriaca), where decoration, illusion, stucco and various theatrical forms went together with the Counter Reformation. The heritage of Turkish and Italian influences did the rest in giving people of the Habsburg lands a sweet tooth. The result is a perfect combination of poor people's cooking (pancakes, doughnuts) and elite confectionery. The cakes (Torten) at the Demel pastry shop in Vienna mirror the abundant decoration of the nearby churches.

Books were an essential aspect in the process of inventing the tradition of Austro-Hungarian cooking. Many of them were published at the turn of the century, mostly written by ladies who wanted to educate cooks and young married women. Recipes were accompanied with advice on how to manage the household, hold dinners and give receptions. Bohemian cooks had their disposal the Bible of Czech cuisine written by Magdalena Dobromila Rettigová back in the Vormärz period, which was regularly reprinted and even translated into German. ${ }^{6}$ It targets the bourgeois woman in the process of emancipation and connects with the Czech national awakening, but it is also designed for more modest readers in the smaller towns and countryside in spite of its relatively high linguistic level and select vocabulary. The author set about gathering around 600 recipes from the "heimatliche tradition" and states that they are Czech. The book became the benchmark of Czech cooking through World War I. Most Czech cooks coming to Vienna carried this book in their luggage. Indeed, around 1880, 46.8\% of the women working in Viennese households are known to have come from Bohemia-Moravia. The first German book acknowledging this influence was published in 1911 by Johann Michael Heitz. His Wiener Bürger-Küche lists recipes qualified as "böhmisch".

Special issues written by Jewish women anxious to combine ritual practices with new trends in social urban life appeared in their turn. Thanks to the command of German common to all educated Jews, these books were popular all over the kingdom, but were also translated and original versions written in Hungarian, Czech and Polish, not to mention Italian in the particular case of Trieste. One of the most famous books was written by a German-Jewish lady from Prague in 1885 (Kauders 2009): the original German version was very soon translated into Hungarian. This is an indication of the growing assimilation of Jews in Hungary. Some wealthy households had servants who were not German-speaking, and therefore some of the "traditional" Jewish dishes belonging to the Galician Jewish cuisine are not mentioned: they were not considered "modern", on one hand, and did not appear on the table of an assimilated family. On the other hand, many recipes were adapted from French, Italian and Hungarian culinary practice. However, in the introduction of these books, the Jewish lady authors deplore the loss of tradition - which here means kosher rules - in the town context. ${ }^{7}$ Many of these ladies also produced books to be studied in girls' institutions and professional cookery schools. ${ }^{8}$ 
The most successful were translated into some of the languages of the monarchy, but those written in German were generally not, because most educated ladies had a knowledge of German and could thus instruct their cooks.Various original books, on the contrary, were written in Hungarian, Czech, Polish and Italian (though for the latter ladies could resort to books published in Italy, these generally lacked references to Austrian cuisine). One of the most famous books, with its 80 editions down to the end of the 20th century and its translation into 16 languages (among them the 11 official languages of the Habsburg monarchy), was first published in 1858 (Peter 2013). The author, Katharina Prato, was born in Graz in 1818; she developed her cooking expertise by trying to cure her husband, who had stomach pain (probably cancer, since he died one year after they were married) (Trefzer 2009). The 358 pages of her book, Die Süddeutsche Küche, were intended for novices and housewives. It was an immediate success, so she continued to work on revising it and adding new recipes: the 24th edition of the book which was published two years before her death in 1895 had reached 712 pages. Her granddaughter, Viktorine von Leitmeier, went on updating the book until the interwar years, adding new recipes to what was now called Die große Prato (Trefzer 2009, 163). Other bestsellers were the book by Marie von Rokitansky, Österreichische Küche, published in 1897, as well as Olga and Adolf Hess's book, Wiener Küche, published in 1913. These books were also translated into various languages of the monarchy, but their recipes are also to be found more or less adapted in editions of original cookbooks throughout the empire, since some belonged to the common heritage of the people.

\section{Conclusion}

The anthropologist Konrad Köstlin considered that the term "Viennese cuisine" was misleading since, according to him, the cooking of late imperialVienna did not exist: it was a retrospective construction: "Resultat einer Selbsterzählung des späten 19. Jahrhundert" (Fendl and Nosková 2010, 105). In actual fact, the definition of so-called Wiener Küche appeared during the last decades of the 19th century from a compilation of all sorts of influences accumulating since the 16th century, at a time when the continental power of the ruling house of Austria extended over large parts of what was to become Austria-Hungary. The capital necessarily concentrated these influences thanks to people's increasing mobility, chefs and cooks in particular. Thus one might even argue that there is no more Viennese cuisine than there is Austrian identity. It is thus not surprising to see that in the interwar period, as well as after 1945, the culinary heritage formed part of the construction of the problematic Austrian identity. The various books recently devoted to this question include chapters dealing with specifically Viennese cuisine (Sandgruber 1997, 187-91). A lieu de mémoire was created with the help of many surviving brands that used to be k.u.k. 
Hoflieferanten. They still play a role in advertising Vienna worldwide, and have even led to the appearance of new products supposedly giving the customer a whiff of the empire. The same phenomenon is obvious in the countries of the former Socialist Bloc, where "Viennese" cafés have opened or reopened; their rooms are often adorned with turn-of-the-century photographs idealizing the town's life before 1918, as well as with portraits of Franz Joseph and "Sissi".

By way of conclusion, I would like to point out once more the crucial role played by empires, and more precisely by the Habsburg Empire, in the construction of an important part of the European gastronomic heritage, as well as for the perception of a shared European cultural dimension. The dimension of the empire conditioned the variety of imports from its nearby and outlying peripheries, a phenomenon that endured until the end. The imperial frame the court, the other centres of power (for the Habsburg Empire meaning Spain, Italy from Lombardy to Sicily, the Netherlands) - created many contact zones with other lands, enabling continuous transfer of influences. Just as Vienna became the melting pot of the empire's populations, so it concentrated a large part of European culinary heritage.

\section{Notes}

1 See the funny story "Die Gans von Podwolotschyska” by Roda Roda, Rote Weste und Monokel. Das neue Roda Roda Buch, Munich DTV, 1999, 136-40.

2 See the film by Hungarian director István Szabó, A Taste of Sunshine (1999), that tells the story of the Hungarian-Jewish Sonnenschein family, who made a fortune out of a new brandy. The model is the Zwack family, who invented the recipe for the famous liquor brand Unicum.

3 Tourism also began to spread towards Bosnia-Herzegovina, which offered a cheaper and nearer version of the "Orient", though it did not provide much adventure in terms of gastronomy, since most of its products were already widely known.

4 See the tribute paid by Franz Werfel to his Czech nanny, Barbara oder die Frömmigkeit, Frankfurt/Main, Fischer, 1990.

5 Géza Kugler, A legujabb és legteljesebb gyakorlati nagy budapesti szakácsköny és házi cukrászat, hires magyar és francia szakács-müvészek nyomán [The Newest and Most Complete Practical Big Budapest Cookbook and Home Confectionery, Following Famous Hungarian and French Cooking Artists]. See also the one devoted to sweet recipes only: A legujabb és legteljesebb nagy házi cukrászat [The Newest and Most Complete Big Home Confectionery], reprint edition, Budapest, Grafo Könyvkiadó, 2008.

6 Domácí kucharka, aneb pojednaní o masitých a postnich pokrmech pro dcerky české a moravské. Quoted in Elisabeth Fendl and Jana Nosková, "Die böhmische Küche", in Heinke M. Kalinke, Klaus Rothand Tobias Weger (eds), Esskultur und kulturelle Identität, 105-36.

7 See, for example, the book written by the wife of the Subotica (Szabadka) rabbi: Rosenfeld Mártonné, A zsidó nö szakácskönyve [The Jewish Woman's Cookbook].

8 Marie Kauders wrote, for example: Kochbuch der ersten israelitischen Kochschule verbunden mit Restauration und Hochzeitsunternehmung. 


\section{References}

Breuss, S. (2003) “Zur Bedeutung des kulinarischen für die Konstruktion österreichischer Identität”, in H.Stekl andE.Mannová(eds), Heroen, Mythen, Identitäten, die Slowakei und Österreich im Vergleich, Wien: Wien Universitätsverlag, 351-72.

Brünner Wochenblatt (1905) “Wochenschrift zur Wahrung deutscher Interessen”, 33(13).

Csáky, M. and Lack, G.C. (eds) (2014) Kulinarik und Kultur: Speisen als kulturelle Codes in Zentraleuropa, Wien; Böhlau.

Danielczyk, J. and Peter, B. (2014) "Die Transnationale des Geschmacks", in M. Csáky and G.C. Lack (eds), Kulinarik und Kultur Speisen als kulturelle Codes in Zentraleuropa, Wien: Böhlau Verlag, 69-82.

Fendl, E. and Nosková, J. (2010) "Die böhmische Küche”, in H. Kalinke, K. Roth and T. Weger (eds), Esskultur und kulturelle Identität: ethnologische Nahrungsforschung im östlichen Europa, München: R. Oldenbourg, 105-36.

Gundel, K. (1988) Kleines ungarisches Kochbuch, 1934; reprint edition Budapest, Corvina. Hobsbawm,E.and Ranger,T.(eds) (1983) The Invention of Tradition, Cambridge: Cambridge University Press.

Jaworski, R. (2014) "Kulinarik als Indikator von Mischkulturen. Gregor von Rezzori und die Küche der Bukowina”, in M. Csáky and G.C. Lack (eds), Kulinarik und Kultur Speisen als kulturelle Codes in Zentraleuropa, Wien: Böhlau Verlag, 161-71.

Kauders, M. (2009) Teljes izraelita szakácskönyv a húsvéti konyha figyelembevételével, Prague: Brandeis, 1890, reprint, Budapest, Gabbiano Print.

Koerner, A. (2004) A Taste of the Past: The Daily Life and Cooking of a 19th Century Hungarian Jewish Homemaker, Hanover-London: University Press of New England.

Köstlin, K. (2014) "Die Wiener Küche. Ein alleinstellungsmerkmal avant la lettre”, in M. Csáky and G.C. Lack (eds), Kulinarik und Kultur Speisen als kulturelle Codes in Zentraleuropa, Wien: Böhlau Verlag, 121-31.

Kugler, G. (1899) A legujabb és legteljesebb gyakorlati nagy budapesti szakácsköny és házi cukrászat, hires magyar és francia szakács-müvészek nyomán, Budapest: Rosznyai.

Kurdiovsky, R. (2012) “Das Kaffeehaus in der Doppelmonarchie.Zwischen WienerTypus und nationalem Ausdruck", in A. Balogh (ed.), Mehrsprachigkeit in Zentraleuropa: zur Geschichte einer literarischen und kulturellen Chance, Wien: Praesens-Verlag, 189-206.

Mártonné, R. (1927) A zsidó nő szakácskönyve, Subotica: Minerva.

Neuber,W.(1987) Die k.u.k.Wiener Küche. Rezepte aus der guten alten Zeit, München: Hahn.

Nora, P. (1984) Les Lieux de mémoire, Paris: Gallimard.

Peter, P. (2013) Kulturgeschichte der österreichischen Küche, München: Beck.

Pohl, H.D. (2007) Die österreichische Küchensprache: ein Lexikon der typisch österreichischen kulinarischen Besonderheiten (mit sprachwissenschaftlichen Erläuterungen),Vienna, PraesensVerlag, 18-20.

Povse, H. and Maurer, R. (eds) (2012), Das Kochbuch der FamilieSchratt, Erfurt: Sutton. Roth, J. (1986) Radetzkymarsch, Munich: DTV.

Sabotić, I. (2004) "Le menu à Zagreb au tournant du XIXe au XXe siècle: dans quelle langue mange-t-on?” Balkanologie 8(2): 55-70.

Sandgruber, R. (1997) “Österreichische Nationalspeisen. Mythos und Realität”, in H. Teuteberg and E. Barlösius (eds), EssenundkulturelleIdentität: europäische Perspektiven, Berlin: Akademie-Verlag, 187-91. 
Schwendter,R.(1995) Arme essen, Reiche speisen: neuere Sozialgeschichte der zentraleuropäischen Gastronomie, Wien: Promedia.

Slovenka (1897) Glasilo slovenskega zenstva, No. 6, 13 March, No. 7, 27 March, No. 8, 10 April and No. 10, 24 April 1897.

Tötschinger, G. (1996) Wünschen zu speisen? Ein kulinarischer Streifzug durch die Länder der österreichischen Monarchie, Wien: Amalthea.

Trefzer, R. (2009) "Das kulinarische Erbe der Donaumonarchie - Katharina Prato", in N. Schreiber and L. Wieser(eds), Wie schmeckt Europa?, Klagenfurt: Wieser Verlag.

Weidhofer, J., Banler-Bachyńska, N. andMeindl, V. (2010), Das Czernowitzer Kochbuch. Ukrainische, rumänische, jüdische, deutsche und polnische Köstlichkeiten aus der Bukowina,Graz-Stuttgart: Leopold Stocker Verlag.

Zintzen, C. (1999) Die österreichisch-ungarische Monarchie in Wort und Bild. Aus dem Kronprinzenwerk von Erzherzog Rudolf,Vienna: Böhlau. 


\title{
Images, perceptions and authenticity in Ottoman-Turkish cuisine
}

\author{
Özge Samancı
}

When discussing the issue of culinary heritage today as well as in the past, the Turkish case appears to be extremely relevant for many reasons, related to the "country's complex status, in and out of Europe geographically, politically, culturally and historically" (Whitehead , Bozoğlu and Daugbjerg 2019, 45). Firstly, the Ottoman Empire included territories which have always been undeniably understood as part of Europe, but it also appeared at times as the "threatening other". When it comes more specifically to gastronomic traditions, the Ottoman Empire worked as a complex system of transfers, influencing foodways and recipes over a long time in a relevant number of present-day nation states. Secondly, this example matters because it deals with cultural and to some extent political uses of gastronomic heritage, and the way the public and private sectors have both rediscovered and used particularly appealing features of the Ottoman past. In fact, in the new millennium Ottoman cuisine has become a popular subject in Turkey's food and drink sector and publishing milieu. Renewal of the Ottoman culinary heritage has produced a duality in imagining the past, and multiple attempts to reconstruct images of the national identity. In the process, various cultural communities have come to light. The main objectives of this study are to understand when and how the subject of cuisine began to be used as a leitmotif in defining Turkish national identity, and to explore the different meanings attributed to the Ottoman culinary legacy in Turkey's nation-building project.

Since the 2000s, one of the main subjects of discussion in the Turkish food and beverage sector and publishing milieu has been the meaning attributed to different culinary heritages such as Ottoman, Turkish, Anatolian and Armenian cuisines, or local cuisines such as those named after the Black Sea or Gaziantep. The publication of cookbooks on these subjects bears witness to the interest in defining these culinary heritages. We can say that cuisine has become a tool to identify and construct the food cultures of diverse national, religious or cultural communities within the Turkish culinary heritage. While making an overview of the Ottoman-Turkish food culture from a historical perspective, the main objective of this study is to highlight the ongoing efforts in Turkey to define and reconstruct Ottoman-Turkish culinary heritage and the so-called 
multiple culinary heritages of different national, cultural and religious communities within the present-day Turkish culinary culture.

Cuisine constructs a community of dialogue, collectively held together by words, by language and by interpretations of the world (Ferguson 2004, 8). The food system in a society is a source of traditions and collective identity. It is a vehicle of self-representation and of cultural exchange and a means of establishing identity, but also the first way of making contact with a different culture (Montanari 2006, 133). There is a strong relationship between food, taste and memory. The emotional experience that we have through taste creates a collective memory that we share with others. This collective memory of taste can be identified as food heritage, reinforcing a group's identity on a small scale and therefore defining a particular group or community, or it can be on a large scale, attempting to solidify nationalistic ideologies or multicultural ideals that aid unity or celebrate cultural diversity (Di Giovine and Brulotte 2014, 14). Different models of food heritage that are imagined in contemporary Turkey contribute to the legitimization of multiple identities.

\section{Reimagining Ottoman cuisine}

In 1999 the 700th anniversary of the foundation of the Ottoman Empire was celebrated with conferences, exhibitions and the publication of books in Turkey and Europe. Ottoman cuisine as a new concept began to contribute to the Turkish culinary world agenda. Prior to that date, literature on Ottoman culinary culture was seldom published. For example, one of the first attempts to write about Ottoman cuisine, which appeared in 1948, was by Süheyl Ünver, a historian of medicine. Ünver's book, Fifty Turkish Dishes in History, consisted of recipes found in an 18th-century Ottoman cooking manuscript. Until the 1980s, apart from a few studies about local foods of Anatolia, past Turkish cuisine was not a significant part of folkloric, academic or popular studies in Turkey (Samanc1 2012, 109). From the 1980s, folklore studies started to include an emphasis on culinary culture, which was motivated especially by increased tourism in Turkey. Public interest in building a national Turkish cuisine engendered publications, underlining the richness of Turkish cuisine. We should note, however, that Turkish cuisine's Ottoman past was not the most important theme in these publications. ${ }^{1}$

Prior to 2000, Timeless Tastes, a book about Turkish culinary heritage published in 1996, was remarkably popular. The book contained essays about Turkish culinary heritage with examples of traditional Turkish recipes. This book, which was sponsored by an important private cultural foundation in Turkey, was translated into English, French and German (Samanc1 2012, 113). Imperial Taste: 700 Years of Culinary Culture, a book on Ottoman cuisine sponsored by the Turkish Ministry of Culture and Tourism, was published in 2000 to celebrate the 700th anniversary of the foundation of the Ottoman Empire (Cevik 
2000). Although the title of the book does not include a direct reference to Ottoman cuisine, the chapter authors directly and indirectly cite Ottoman culinary heritage as the basis of contemporary Turkish cuisine. As mentioned by Defne Karaosmanoğlu, "this book aims to create an image of Turkey through a rich history, and it focuses more on heritage and historical continuity than on the exoticism of the Ottoman culture" (Karaosmanoğlu 2006, 94). We should mention other books published since 2000 that contributed significantly to the renewal of Ottoman cuisine, with an emphasis on its cosmopolitan character as well as its imperial origin. For example, Tuğrul Şavkay, a well-known food columnist, emphasized the idea of a kind of "cosmopolitan Ottoman cuisine" (Şavkay 1999) in which multiple cultural communities contributed much to the formation of Ottoman cuisine. In addition, Marianna Yerasimos, in her book titled 500 Years of Ottoman Cuisine, primarily introduced Ottoman imperial cuisine by referring to the traditions of cooking, serving and eating in the Ottoman palace (Yerasimos 2002). Both Savkay's and Yerasimos' books included Ottoman recipes adapted for modern tastes. Parallel to the publication of books about Ottoman culinary heritage, high-end restaurants with a desire to serve Ottoman cuisine have flourished in Istanbul since 2000. These restaurants have Ottoman-related names such as Tuğra, which means the signature of the Ottoman sultans; Feriye, the name of an old Ottoman palace; Cintemani, an Ottoman motif; and Asitane, the old Ottoman name for Istanbul. The publication of books on Ottoman cuisine and the rise of Ottoman-style restaurants denote a new approach to defining Turkish national cuisine. Reference to the Ottoman past became legitimate when reconstructing Turkish cuisine's past. At the same time, the reconstruction of Turkish cuisine with Ottoman motifs continues to enhance Turkey as a culinary destination for foreigners, thus promoting tourism.

Ottoman cuisine, as Turkish cuisine's rediscovered heritage since the 2000s, has today become a very popular subject in the media and restaurant trade in Turkey. The publication of cookbooks on Ottoman cuisine has also become more popular. For example, Ömür Akkor's book, titled Ottoman Cuisine: A Rich Culinary Tradition, published in 2014, has become a bestseller. Some of the Ottoman restaurants serve examples of old dishes as well as beverages discovered in the Ottoman cookbooks and manuscripts, some of them invent new dishes with reference to Ottoman dishes, and others simply promote key traditional dishes of Turkey as examples of Ottoman cuisine. There is not a clear, precise definition attributed to Ottoman cuisine. For some people, it represents the food culture of the Ottoman palace; for others, it is traditional Turkish cuisine or the food heritage of multiple ethnic communities (Samanc1 2018b, 162). As mentioned by Rohdewald $(2018,298)$, "the imagination of an Ottoman past in cookery books turns out to be various, mirroring, reproducing and broadening the other." In real terms, considering the vast geographical territories, the religious and ethnic cultural diversity and the long history of the Ottoman Empire, 
defining Ottoman cuisine as a unique and static culinary culture is problematic. Therefore, the meaning attributed to Ottoman cuisine continues to be a subject of intense discussion in Turkey's gastronomic milieu today.

\section{The cosmopolitan character of Ottoman cuisine}

The revival and legitimization of Ottoman cuisine in Turkey since the 2000s highlight different consequences that contribute directly and/or indirectly to the construction of national imaginary connected to cuisine. The Ottoman culinary heritage aided the creation of a sense of continuity from the past to the present for Turkish culinary traditions. The celebrated Ottoman cuisine, especially the Ottoman palace cuisine, became a source of inspiration as well as a source of pride in defining the history of Turkish cuisine. In addition, Ottoman multicultural culinary culture became a subject in which the notion of cosmopolitanism is discussed from cultural and political perspectives. As a result, the cosmopolitan Ottoman cuisine that embodies the multi-religious, multicultural and multi-ethnic food heritages became an important subject matter for food writers and journalists. Cookbooks, including Be Merry Around Our Table, a book of nostalgia representing Armenian culinary traditions in Istanbul (Tovmasyan 2004); Dishes Cooked in Armenian, Rum, Jewish and Muslim Houses in Istanbul (Kara 2017); Sephardic Cuisine (Koronyo 2003); Recipes from Rums of Istanbul (Bozis 2012); or Kurdish Culinary Culture and Kurdish Dishes in Anatolia (Bender 2003), all published since 2000, aim to represent the multi-ethnic and multi-religious cosmopolitan culinary heritages in present-day Turkey. The authors of these publications exemplify the desire to remember and underline diversity in Turkey. These cookbooks, which aim to present authentic tastes of Armenian, Greek, Kurdish or Sephardic cuisines, also aim to pay tribute to the ethnic identities within the Ottoman Empire. Multicultural Ottoman food heritages help to compose and recompose cultural and historical boundaries in Turkish history. It can be argued that the representation of ethnicity through these cookbooks contributes to the creation and circulation of ethnic perceptions inside and outside of Turkey today (Di Giovine and Brulotte 2014, 16). But in real terms, defining the differences between these so-called ethnic food heritages is not very easy or accurate, because similar culinary techniques and a common gastronomic lexicon exist within a shared and common historical Ottoman food culture.

Cookbooks published in Turkish using the Arab and Armenian script during the second half of the 19th century, exemplifying the existence of a cuisine shared by both Ottoman Muslim and Armenian communities in Istanbul, validate the aforementioned argument. The recipes in two Armenian cookbooks published in Istanbul, Keys of Cooks (1876) and New Cookbook (1889), ${ }^{3}$ have similarities with the five Ottoman cookbooks that were published in Istanbul in the 19th century. ${ }^{4}$ Soups (çorbalar), braised vegetable and legume dishes 
(bastı, yahni), kebabs prepared with lamb, game, poultry, fishes, fried fishes, meat stews (yahni), grilled meat (külbastı), meatballs (köfte), stuffed vegetables (dolma, sarma), pilafs, eggs (kaygana), pastry dishes both savoury (börek) and sweet (such as baklava), halva, fruit compotes (hoşaf), sorbets (şerbet), cordials (şurup), jams (reçel) and pickles (turşu) comprise the traditional types of dishes that exist in both Turkish and Armenian cookbooks. We should mention that both types of cookbooks represent the culinary culture of Istanbul that was formed over the centuries as a result of the amalgamation of culinary techniques and food traditions practised by all the inhabitants of the Ottoman capital, including Muslims, Armenians, Rums, Jewish and Levantine peoples. However, the Armenian and Ottoman cookbooks have two important differences. First, the Armenian cookbooks include recipes for pork dishes. Not surprisingly, pork recipes were absent from Ottoman cookbooks written for Muslim communities. Religious beliefs constituted the essential boundaries between the cuisines of different religious communities in the Ottoman Empire. In addition, new European recipes, namely in the French style, are more numerous in Armenian cookbooks. A new style of cuisine called alla franca, in the European style, became popular among Istanbul's elite, including in the Ottoman palace, during the last decades of the 19th century. New recipes in the French style, along with new European-style table manners (dining at a high table with forks and knives instead of at a low table) were adopted initially and voluntarily by the non-Muslim elites of the capital. Some of the non-Muslim elites of Istanbul - especially those who were French-speaking - had been involved in commercial activities in Istanbul since the 1850s. This subpopulation may have had easier access to the European style of life, including new alla franca dishes served in the modern restaurants, cafés, pastry shops and brasseries opened in Péra (the European district of Istanbul) by European and Levantine entrepreneurs (Samanc1 2015,187). Cookbooks published in the 19th century in Istanbul reflect a culinary synthesis shared by different religious communities. For centuries, Istanbul had been a house for many religions and therefore Muslims, Christians and Jewish people lived in the city. The interaction between different cultural groups had an impact on the formation of a hybrid and rich cuisine over time, which can be defined as Istanbul's cuisine. For example, braised dishes named pilaki, prepared with mussels, fish or oysters, were delicacies in the cuisine of the Christian communities of Istanbul. Stuffed vegetables cooked in olive oil (yalancı dolma), seafood dishes and pilaki were among the special dishes prepared by Christians in Istanbul, especially during Lent, the fasting period. As witnessed by 19th-century cookbooks, these dishes, which emerged initially as a result of the religious dietary restrictions of Christian communities in the Ottoman Empire over a long period (Mattaiou 1996), became in time common dishes consumed by all the cultural communities in Ottoman cities, including Istanbul (Samanc1 2015). Most of these dishes are still a part of modern Turkish and Greek cuisine. 


\section{Turkish cuisine or Anatolian cuisine: on the way to constructing Turkish national cuisine}

As we mentioned previously, defining culinary heritages in Turkey is a problematic issue today. Defining or naming one of these culinary heritages as Ottoman, Turkish, Armenian or Rum suggests the supremacy of one of these cultures in Turkey. Some food writers, authors of cookbooks or chefs prefer to use the term Anatolian cuisine to identify the food culture of Turkey. They think that the expression Turkish cuisine connotes a nationalistic approach that does not cover the rich, multicultural and ancient culinary heritages of Anatolia. Mehmet Gürs, one of Turkey's well-known chefs and restaurant owners, when representing his concept of a New Anatolian Kitchen in his restaurant, defines the Anatolian kitchen in his manifesto as follows: "The Anatolian kitchen is not restricted to the Turkish or the Ottoman kitchen. All products of different ethnic origins and religions of Anatolia, the birthplace of cultures during a very long span of time before and after the Ottoman Empire, constitute the kitchen of this region." 5 The expression Turkish cuisine represents in this perspective an ethnic cuisine inherited from the Turkish people who have migrated to Anatolia from Central Asia since the 11th century. Gürs is against this nationalistic approach, which excludes the culinary heritages of other cultural and ethnic communities. In real terms, the expression Turkish cuisine represents for most people all of the culinary practices performed within the geographical boundaries of today's Turkey. But today the subject of cuisine in Turkey has become politicized and has become a sensitive subject. Instead of Turkish cuisine, the expression cuisine of Turkey is another term used nowadays in order not to exclude any historical or cultural heritages.

We should note that during the early days of the Republic, compared to other aspects, cuisine did not play any significant role in the nation-building project or in the definition of the Turkish national identity. For example, unlike language, the culinary heritage of nomadic Turkic people from Central Asia did not become a source of inspiration in Turkish folklore studies, which have contributed to defining the Turkish nation (Sauner-Nebioglu 1995, 61). Instead, the construction of national Turkish cuisine, which tends to unify or homogenize different culinary practices in Turkey, has been realized in a different manner. Istanbul's cuisine exemplifies the summit of Ottoman culinary culture formed in the kitchens of Ottoman palaces and mansions over the centuries. It was initially represented in 18th-century Ottoman cooking manuscripts, and became codified in the Ottoman cookbooks (both Turkish and Armenian) that started to be published in Istanbul during the 19th century. This cuisine, which also represents the interaction between European - mainly French - and Ottoman cuisine during the last phase of the empire in the late 19th century, continued to be reproduced via cookbooks published in the early years of the Republican era, in the 1930s. We should note that new table manners 
and new culinary techniques inspired by European culinary cultures were the major novelties embraced by Ottoman elites in the 19th century (Samanc1 2018b, 95). Several cookbooks on Turkish cuisine were published during the Republican era in Turkey. Some of them became bestsellers; for example, The Perfect Cookbook of Alla Turca and Alla Franca Dishes and Desserts, first published in 1933 by a female author, Fahriye Nedim, was republished 18 times up to the 1980s. Another title, Culinary Education in Alla Turca and Alla Franca Style, written by a culinary instructor, Ekrem Muhittin Yeğen, was issued 25 times between 1946 and 2016. Note that the titles of the cookbooks published from the 1930s to the 1970s did not make any direct reference to Turkish cuisine. This cuisine was also served to the customers in hotels and restaurants in larger cities such as Istanbul and Ankara. The elite cuisine of Istanbul, defined as the Turkish cuisine represented in cookbooks, became in time the standard for an entire nation through the Republican-era culinary education programme in girls' schools and more recently in cooking schools. Girl Institutes opened to teach young women how to cook modern dishes that were economical and high in nutritional value (Yenal 2003). In 1971, a well-known Turkish chef, Necip Ertürk, published a cookbook called Art of Turkish Cuisine. This was the first mention of Turkish cuisine in a cookbook published in Turkey. The 1970s saw the beginning of tourism in Turkey, and Ertürk was a famous chef who worked in the newly opened luxury hotels in Turkey. It can be argued that the publication of cookbooks on Turkish cuisine, the presence of Turkish cuisine in culinary education and the rise of restaurants that served Turkish cuisine all contributed directly or indirectly to the formation of a national Turkish culinary identity. The concept of Turkish cuisine served as a common symbol of the nation and then acted as a medium to solidify the national identity. As mentioned by Atsuko Ichijo and Ronald Ranta (2016), cuisine therefore served unofficially in the construction of a national identity from the bottom up.

Today, the construction of a national Turkish cuisine has also created a challenge to discover the different regional cuisines in Anatolia. Culinary writings about regional cuisines in Turkey ${ }^{6}$, as well as culinary events organized around regional food, encourage the construction of a sense of community identity that tends to solidify the nation-building project. The different regions that make up Anatolia each offer their culinary individuality, linked to their ecological heritage and the various influences these receive or have received in the past (Sauner-Nebioglu 2008, 262). Today's regional cuisines in Anatolia include the Black Sea (iconic foods are anchovies, maize and kale), Mediterranean (represented by citrus fruits, tahini and pomegranate), southeast Anatolian (famous for kebabs and lahmacun - a kind of flatbread topped with minced meat mixture made of parsley, onions, red peppers, tomatoes and baklava), Aegean (renowned for fish, shellfish dishes, olive oil and wild herbs), central Anatolian (homeland of wheat, bulgur and a savoury pastry called börek), eastern Anatolian (land of butter, meat and wheat) and Marmara 
cuisines (representing the Ottoman culinary heritage). These tend to accentuate their differences in tastes and culinary practices from the national Turkish cuisine represented in Istanbul. We should note that people who have migrated from Anatolia to Istanbul articulate nostalgia for their homeland through food. Since the 1950s, migrants from eastern Anatolia to Istanbul have started to open food outlets where they sell their local food products such as spicy kebabs on skewers, lahmacun, içli köfte (bulgur meatballs stuffed with walnut, minced meat and paprika) or çĭg köfte (raw meatballs made of minced meat, paprika and tomato paste and fine bulgur).

The subject of Turkish national cuisine has also become important because of the culinary struggle between Turkey and its neighbouring countries. The culinary tussle between Turkey and Greece is the best example (Karaosmanoglu $2006,84)$. The food wars regarding the origin of some iconic foods such as baklava, Turkish delight and Turkish/Greek coffee created a desire to legitimize Turkish culinary heritage. The effort to inscribe Turkish culinary rituals, along with some food items, on UNESCO's list of the Intangible Cultural Heritage of humanity can be interpreted as an outcome of this culinary tension between nations. The inscription of "Turkish coffee culture and tradition" in UNESCO's representative list of the Intangible Cultural Heritage of humanity ${ }^{7}$ in 2013 thus became a source of pride, which was celebrated with exhibitions, events and publications in Turkey during the following years. ${ }^{8}$

Differentiating very distinct ethnic and regional cuisines within Turkish culinary culture is challenging. While similar culinary techniques and dishes are present simultaneously in numerous ethnic, religious and local communities in Turkey and even in neighbouring countries in the Balkans and the Middle East, it is difficult to define totally distinctive and different culinary heritages. Culinary differences due to the geographical environment, historical background or religious rituals do indeed exist in these locations, but similarities are more pertinent. The culinary cultures of the contemporary Middle East and the Balkan region have coherent patterns. As mentioned by

Sami Zubaida and Richard Tapper $(1994,2)$, this coherence is the product of successions and articulations of political and cultural hegemonies established by successive dynasties and elites in history. The Ottoman culinary legacy is the common denominator in this coherence.

\section{Ottoman culinary heritage}

Considering the long shared history across the vast territories of the Ottoman Empire, the formation of food cultures in the Middle East, Anatolia and the Balkans reflects a synthesis of multiple culinary heritages in which migrations, wars, political domination, trade and religions played important roles. The culinary heritage of these regions has been formed over the centuries as a result of culinary amalgamation of ancient Anatolian and Mediterranean 


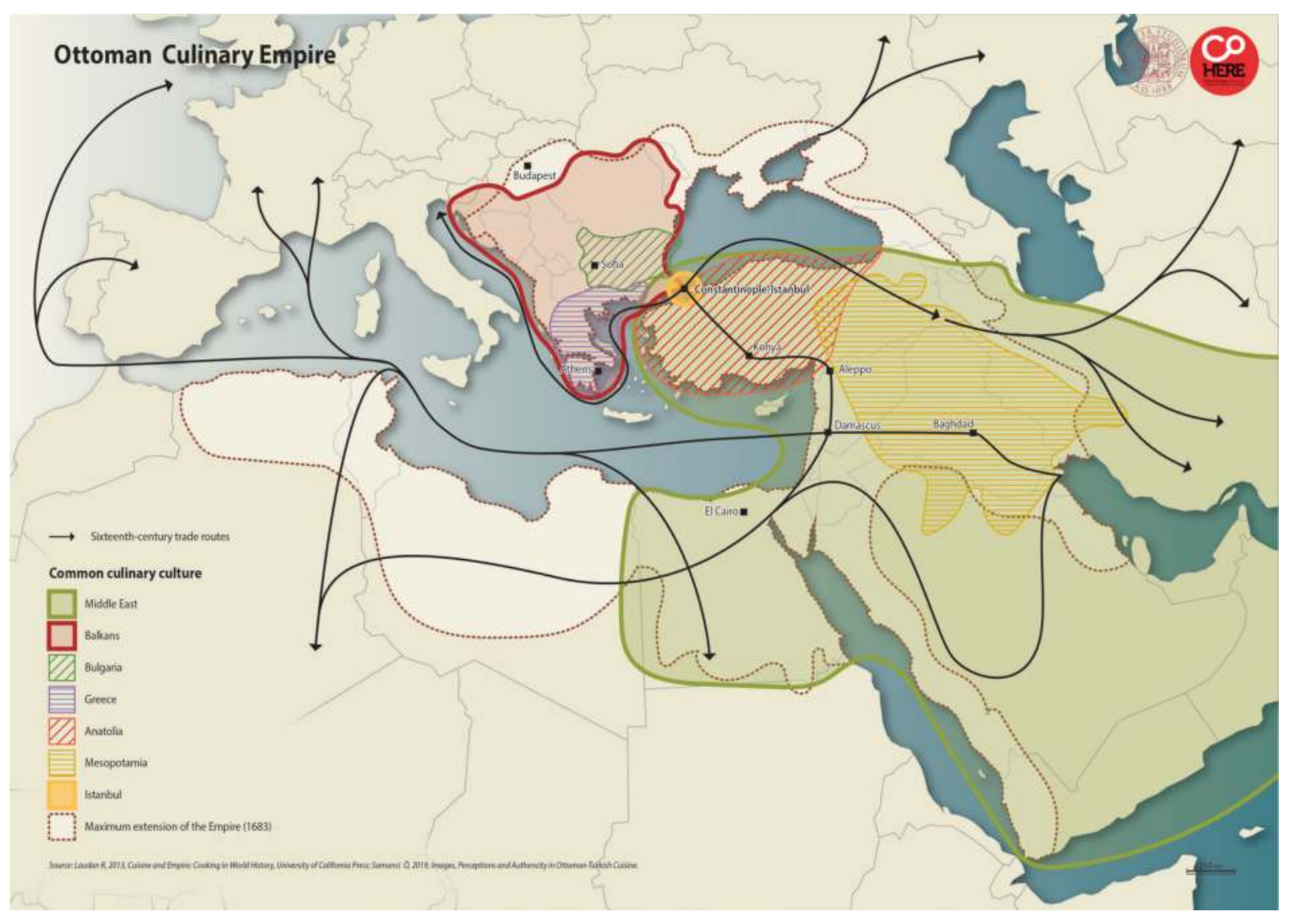

Figure 9.1 Ottoman Culinary Empire 
civilizations and of nomadic Turkish, medieval Arab-Persian, Byzantine and Ottoman cultures. Among these ancient culinary heritages, the last is Ottoman. Although culinary habits and traditions were noticeably changed, enriched or renovated in the Ottoman territories from the end of the 14th century to the last days of the empire in the 1920s, a coherent gastronomic language with some distinctions was formed in the vast territories of the empire. The rise of nationalist movements in the Ottoman territories - first in the Balkans - since the 19th century tended to disrupt the culinary coherence of the Ottoman Empire with new discourses.

Ottoman cuisine bears the mixed imprint of the culinary traditions of the nomadic Turkic peoples, of the medieval Arabic-Persian cuisine and of the Seljuk and Byzantine cuisines. After the Ottoman conquest of Istanbul in 1453, the city became the capital of the empire: the centre of administration, commerce and culture. At the same time, Ottoman palace cuisine became an important symbol of the imperial city. Culinary trends in the Ottoman Empire were shaped mainly by Istanbul's elites. As the capital of the Ottoman Empire, Istanbul had the privilege of sourcing the best and most varied ingredients from each of its regions. Beyond the food items and products of its immediate territorial limits, the kitchens of Istanbul also used foodstuffs from distant geographical regions of the empire (Samanc1 2015, 137-68). For centuries, the Ottoman territories, including Istanbul, were a house for different cultural groups where Sunni Muslims, Alevi, Orthodox Christians, Catholics and Jews mingled and cohabited. The interaction between these cultural groups had an impact on the formation of a hybrid and rich cuisine over time. Istanbul's cuisine in the 19th century thus reflected the imperial traits, the multicultural notes and these historical heritages. As we mentioned earlier, the last decades of the 19th century and the first half of the 20th century also witnessed the partial impact of French cuisine on Ottoman elite cuisine. During the second half of the 19th century, European lifestyles as well as culinary habits became sources of inspiration for those among the Ottoman elites who supported reform. Thus a new style of eating called alafranga (alla franca, i.e. European style) became fashionable within Ottoman elite circles from the 1850s. European-style table manners, having meals on a high dining table and using individual services, were increasingly in use among the Ottoman elites. Parallel to the novelties adopted into the Ottoman culinary etiquette, European cuisine, especially French, started to influence the Ottoman elites' cuisine (Samanc1 2018b, 93).

Istanbul played a unique role as a capital throughout the territories under Ottoman rule for its incomparable metropolitan urban life (Fragner 1994, 52). As it evolved in the kitchens of the Ottoman palace and the elite households of Istanbul from the 15th century to the end of the empire, the culinary culture of the Ottoman capital city represented the elegant and refined tastes of the Ottoman elites (Samanc1 2015). Istanbul's cuisine was thus an exemplar for the rest of the empire. For example, in 1870, the first cookbook published in Bulgarian, titled Every Type of Dishes Prepared in Istanbul (Tsarigrad) Style, 
reflected the interest of Bulgarian elites in Istanbul cuisine (Detchev 2015, 14). As Detchev remarked, the cookbook mirrored cosmopolitan Istanbul cuisine. Istanbul cuisine was a source of inspiration for the elites of Ottoman Balkan territories until the rise of nationalist movements in the 19th century. From this point, European-style cuisine was embraced in Bulgaria and Greece as they sought to construct a new culinary identity in contrast to the historical Ottoman culinary influence. Cookbooks published in Greek in 1828 and 1860 were translations of two Italian and French cookbooks. The reason for the publication of these cookbooks was the desire to break with the roots of Ottoman culinary heritage and to create a new national identity (Notaker 2002, 147).

Bert Fragner $(1994,52)$ has written that "despite the disintegration of the Ottoman political Empire, we can still see the survival of a large region which could be called the Ottoman culinary empire". The Balkans, Greece, Anatolia and the Middle East share today a common culinary culture, with certain regional differences. We can argue that a similar gastronomic language is still present in Istanbul, in Turkey and in old Ottoman territories including Greece, Bulgaria, the old Yugoslavian territories and Mesopotamia. The diffusion of a common gastronomic language that covers comparable culinary techniques and dishes in Ottoman territories is not easy to explain. The long historical background should be considered, in which migration, trade and population exchanges played roles in the mutual dissemination of cultural practices, including culinary ones. The Ottoman Empire ruled the Balkans and the Middle East for many centuries and thus deeply affected those territories in various areas such as politics, economy, culture, religion and society (Sancaktar 2011). These effects have inevitably turned into legacies on various levels and in various areas, including the culinary field. The presence of Ottoman governmental officers in the Ottoman provinces from the very beginning of the empire contributed to the transmission of Ottoman elite food culture to the remote reaches of the empire. Ottoman public kitchens (imarets) opened in Ottoman cities; there, free meals distributed on behalf of the Ottoman palace also signalled the Ottoman presence throughout the empire (Singer 2011).

As I pointed out in my recent work based on European travelogues on the Balkan regions in the 19th century, the culinary practices of local people in Greek and Bulgarian cities have common characteristics with Ottoman Istanbul's culinary culture of that period (Samanc1 2018b). The basic types of dishes, such as pilaf, roasted lamb (called kebab in Istanbul cuisine), savoury pastries, sweet pastries in syrup, stuffed vegetables (dolma), sherbets, halva and food items such as yogurt, pastrami, clotted cream, salted (brined) white cheese and caviar existed both in Istanbul and in Balkan cuisines. The style of serving at the table and the table manners were also the same. Both in the Balkan territories and in Istanbul, Christians respected their fasting days. During Lent, Christians refrained from eating meat and animal products, except shellfish and sometimes fish. Vegetables, caviar, botargo (salted cured fish roe), savoury pastries filled with herbs and even snails were typical Lenten foods in Greece. The 
influence of European cuisine in terms of the adoption of new table manners, the consumption of imported food products from Europe and the adaptation of new European-style culinary techniques were other common points shared by Istanbul and Balkan cuisines amongst elites during the second half of the 19th century. As mentioned by Rayna Gavrilova, in the 19th century, the modernization process in South-East Europe favoured the consumption of imported food items from Western Europe. Two cookbooks published in Bulgaria after the 1850s witness the introduction of new recipes and culinary techniques adopted from Western Europe. Traditional Turkish-style dishes such as kebab, jachni (stew), chorba (soup) and dolma (stuffed vegetables) are present alongside new European dishes in these cookbooks. These cookbooks also testify to the substitution of Turkish names of dishes by European culinary terms, demonstrating the desire of Bulgarian elites to break with their cultural Ottoman past (Gavrilova 2002, 101-18).

The cuisines of the old Ottoman territories (present-day Turkey included) attempt today to identify their respective regional and communal boundaries. However, they exist within a common cultural knowledge. Instead of homogeneity of culinary culture, a common culinary vocabulary is prevalent, which covers the same or different dishes and culinary techniques. There are abundant examples of common dishes, such as yogurt mixed with cucumber, which is called cactk in Turkey, tzatziki in Greece and tarator in Bulgaria; or stuffed vegetables, which are known as dolma in Turkey, dolmades in Greece and sarma in Bulgaria. Sarma represents a good example of common dishes known in Middle Eastern and South-East European cuisines. The term sarma, meaning wrapped in Turkish, refers to leaves (raw or more often briefly blanched, or kept in salt brine) rolled around a filling made of rice, bulgur and/or minced meat, onions and spices, braised in a pot and generally consumed warm (with meat) or cold (without meat). Sarma represents a famous dish of the traditional cuisines of the former Ottoman territories: Turkey, the Balkans, the Middle East and North Africa (Doğan et al. 2015).

\section{Conclusion}

As we mentioned earlier, the Ottoman past of Turkish cuisine, or the subject of cuisine itself, was not voluntarily used as a tool in the political agenda of governmental organizations in constructing the Turkish nation during the early decades of the Republic. The reconstruction of a supposedly national Turkish cuisine that tries to unify or homogenize different culinary practices in Turkey has become a social fact over nearly 200 years and can be interpreted as a movement realized from the bottom up. The Ottoman cookbooks of the 19th century, followed by the Turkish cookbooks published during the 20th century, representing similar culinary knowledge, comprised the fundamentals of this national Turkish cuisine. This cuisine, which mainly represents Istanbul's elite food culture, mostly comprises flavours of the Ottoman culinary culture 
inherited from the past. The analysis of cookbooks published in Istanbul (whether written in old Ottoman, Armenian or modern Turkish) from the 1850s to the 2000s suggests that a common culinary terminology of names of dishes and techniques has endured throughout these publications. From the 19th century to the 2000s, ingredients used in these cookbooks have obviously changed and new types of dishes have emerged. But at the same time, the basic types of dishes, such as kebab, baklava, pilaf, börek (savoury pastry), kadayıf (dough-based dessert soaked in syrup, including vermicelli-style pancake or cake), helva (the generic type of Ottoman dessert like a thick porridge based on butter, flour/semolina/starch and syrup), dolma/sarma (stuffed vegetables/ leaves) and musakka (fried eggplant with minced meat) have persisted to the current day.

Since the beginning of the 21st century, a new discourse related to the food culture in Turkey has become evident. Ottoman cuisine has become a popular topic in cookbooks, the media and the food and beverage sector in Turkey. The publication of books on Ottoman cuisine and the rise of Ottoman-style restaurants suggest a new approach to defining Turkish cuisine. The search for an Ottoman cuisine dissimilar to the contemporary Turkish cuisine has become evident. In this search for an exotic Ottoman cuisine, it was forgotten that most current Turkish dishes originated in the Ottoman era. The newly constructed image of Ottoman cuisine, then, reproduced a dual meaning inspired both by the celebrated past of the Ottoman palace and by the cosmopolitan character of the empire. The revival and legitimization of Ottoman cuisine in Turkey since 2000 thus created new dynamic forces in the nation-building project of Turkish cuisine. The Ottoman past began to be used in reconstructing the image of Turkish national cuisine. In addition, the recognition of the Ottoman past reproduced new images of cuisine referencing multicultural identities (Armenian, Rum, Circassian or Kurd) that tended to interrogate the validity of the image of a national Turkish cuisine. Moreover, the search for an Ottoman identity in Turkish cuisine engendered a desire to authenticate the culinary richness of Anatolia; therefore, regional and local cuisines in Turkey became important in this new approach to defining Turkish cuisine.

As we tried to demonstrate in the previous section of this chapter, the Ottoman culinary legacy created a kind of gastronomic coherence across the old Ottoman territories, including present-day Turkey. In the presence of a shared culinary inheritance in Turkey, it is not easy to differentiate clearly any ethnic, cultural, regional or local cuisines. However, the historical reality and facts do not always contribute directly to nation-building projects; thus, the identity of "Turkish cuisine" will continue to be discussed and will remain under construction in the coming decades.

Nation-building projects that tend to unify people around food identities and culinary heritages denoting an authenticity emerge not only in today's Turkey, but were also evident in old Ottoman territories, namely in SouthEast Europe and the Middle East. We should note that, in the 19th century, 
the subject of food had already become a source of inspiration in imagining national identities in the Balkans. The publication of cookbooks in vernacular languages such as Greek, Bulgarian and Romanian implies a desire both to build a modern national cuisine inspired by Western Europe (namely French cuisine, which at that time was accepted and adopted by the rest of the Western world as a culinary model) and to erase the Ottoman past (Notaker 2002). Most of the cookbooks published in the late 19th century in South-East Europe did not include names of dishes from the Ottoman past. However, Ottoman dishes, recognized now as a part of each national cuisine in the Balkans, are used as tools in constructing national and culinary identities. Today, culinary struggles between Balkan countries and Turkey have become evident. In Greece, Bulgaria, Romania, Albania, Croatia, Bosnia or Turkey, deciding about the origin of foods such as yogurt, stuffed wine leaves, baklava, coffee or savoury pastry (börek in Turkish) is a hot topic of discussion in popular culinary writings, including websites. However, most of the time, these discussions neglect the fact of a shared history and culture between these nations.

\section{Notes}

1 In this chapter, only popular studies and cookbooks about Ottoman and Turkish cuisine are used as primary sources. Studies employing a scientific approach that tend to analyse food culture of the Ottoman society from historical or anthropological perspectives are not included. For further research, please refer to Samanc1 (2012).

2 Rum refers to the Greek population living in Ottoman territories.

3 I would like to thank Turgut Kut, who provided me with the content lists of these cookbooks.

4 The Ottoman cookbooks published in Turkish using the old alphabet in the 19th century were Mehmet Kamil (1844) Refuge of Cooks (Melceü't-Tabbahin), Istanbul; New Cookbook (Yeni Yemek Kitabı) in 1880, Istanbul; Ayşe Fahriye (1883) Housewife (Ev Kadını), Istanbul. Mahmut Nedim bin Tosun; (1900) The Chef (Aş̧̧ıbşı), Istanbul.

5 www.miklarestaurant.com/en/the-new-anatolian-kitchen.

6 Examples of Turkish regional cookbooks published since the 2000s are Bayrak (2015a, 2015b); Tan (2014). www.alfayayinlari.com/kitap.php?id=198130

7 https://ich.unesco.org/en/RL/turkish-coffee-culture-and-tradition-00645.

8 www.kulturvarliklari.gov.tr/TR,130700/topkapi-sarayi-muzesinde-bir-tasimkeyif-turk-kahvesini-.html.

\section{References}

Ayşe, F. (1882) Ev Kadını, Istanbul: Mahmud Bey Matbaası. Bayrak, F. (2015a) Soframda Anadolu İç Anadolu Yemekleri, Istanbul: Alfa Yayınevi. Bayrak, F. (2015b) Soframda Anadolu Karadeniz Yemekleri, Istanbul: Alfa Yayınevi. Bender, C. (2003) Kürt Mutfak Kültürü ve Kürt Yemekleri, Istanbul: Berfin Yayınları. Bilgin, A. (2004) Osmanl Saray Mutfă̆ı, Istanbul: Kitabevi Yayınları. 
Bozis, S. (2012) Istanbul Rumlanndan Yemek Tarifleri, Istanbul: Yapı Kredi Kültür Yayınları.

Çevik, N. (ed.). (2000) Hünkar Beğendi 700Yillı Mutfak Kültürü,Ankara: Kültür Bakanlığ1 Yayınları.

Çevik, N. (2006) Imperial Taste: 700 years of Culinary Culture, Ankara: Ministry of Culture Publication.

Detchev, S. (2015) “Seçkin Osmanlı Mutfağı ile Avrupa Arasında Slaveykov'un 1870 Tarihli Kitab1 ve Modern Aşç1lığa Giden Yol”, Yemek ve Kültür 42: 14-41.

Di Giovine, M.A. and Brulotte, R. (2014) Edible Identities: Food as Cultural Heritage (Heritage, Culture and Identity), 2nd edition, New York: Routledge.

Doğan,Y., Nedelcheva ,A., Łuczaj, L., Drăgulescu, C., Stefkov, G., Maglajlić, A., Ferrier, J., Papp, N., Hajdari, A., Mustafa, B., Dajić-Stevanović, Z. and Pieroni, A. (2015) "Of the importance of a leaf: the ethnobotany of sarma in Turkey and the Balkans", Journal of Ethnobiology and Ethnomedicine 11: 26.

Ertürk, N. (1971) Türk Mutfak Sanatı, Istanbul: Kral Matbaas1.

Ferguson, S. (2004) Accounting for Taste: The Triumph of French Cuisine, Chicago: University of Chicago Press.

Fragner, B. (1994) "From the Caucasus to the roof of the world", in S. Zubaida and R. Tapper (eds), Culinary Cultures of the Middle East, New York: I.B. Tauris, 49-62.

Gavrilova, R. (2002) "Ex Occidente Lux: Les produits occidentaux et la modernisation de la culture culinaire dans l'Europe du Sud-Est au XIXe siècle", in M. Bruegel and B. Laurioux (eds), Histoire et Identités Alimentaires en Europe, France: Hachette Littérature, 101-19.

Ichijo, A. and Ranta, R. (2016) Food National Identity and Nationalism from Everyday to Global Politics, Basingstoke: Palgrave.

Işıı, P.M. (ed.) (1998) Mahmud Nedim bin Tosun Aş̧̧başı, Istanbul: Yapı Kredi Yayınları.

Kara, G. (2009) "Eating the past, multiple spaces, multiple times - performing 'Ottomaness' in Istanbul”, International Journal of Cultural Studies 12(4): 339-58.

Kara, G. (2017) Ermeni, Musevi ve Rum Evlerinde Pişen Yemekler, Istanbul: Hayy Kitap.

Karaosmanoğlu, D. (2006) Cooking the Past: The Revival of Ottoman Cuisine, Unpublished PhD thesis, McGill University.

Koronyo, V. and Ovadya. S. (2003) Sefarad Yemekleri Sephardic Cooking Book, Istanbul: Gözlem Yayıncılık.

Kut, G. and Kut, T. (eds), (2015) Melceü’t-Tabbahin Aş̧̧lann Sığınă̆ı Mehmed Kamil, Ankara: Türkiye Yazma Eserler Kurumu Başkanlığı Yayınları.

Kut, T. (1990) “A bibliography of Turkish cookbooks up to 1927”, Petits Propos Culinaires 36: 29-48.

Mattaiou, A. (1996) "La longue durée de l'alimentation: permanences rurales et différenciations urbaines en Grece sous la domination ottoman", in S. Cavaciocchi (ed.), Alimentazione e nutrizione Secc. XIII-XVIII, Florence: Le Monnier, 313-23.

Montanari, M. (2006) Food Is Culture, New York: Columbia University Press.

Nedim, F. (1933) Alaturka ve Alafranga Mükemmel Yemek ve Tath Kitabı, Istanbul: Inkılab Kitabevi.

Notaker, H. (2002) “En contrepoint. L'identité nationale a travers les livres de cuisine du XIXe siècle", in M. Bruegel and B. Laurioux (eds), Histoire et Identités Alimentaires en Europe, France: Hachette Littérature, 137-50. 
Rohdewald, S. (2018) "Neo-Ottoman cooking in Turkey in the twenty-first century: cooking as a means to imagine a common past and future", in A. Blaszczyk and S. Rohdewald (eds), From Kebab to Cevapcici Foodways in (Post)-Ottoman Europe, Wiesbaden: Harrassowitz, 289-300.

Samanc1, Ö. (2012) "Food studies in Ottoman-Turkish Historiography", in K. Klaflin and P. Scholliers (eds), Writing Food History: A Global Perspective, New York: Berg, 107-20.

Samanc1, Ö. (2015) La cuisine d'Istanbul au 19e siècle, Rennes: PUR-PUFR.

Samanc1, Ö. (2018a) "The cuisine of Istanbul between East and West during the 19th century", in A. Jianu andV. Barbu (eds), Earthly Delights: Economies and Cultures of Food in Ottoman and Danubian Europe, c. 1500-1900, Leiden: Brill, 77-98.

Samanc1, Ö. (2018b) "Ottoman food culture in the Balkan Peninsula through the exotic views of the 19th century traveller's accounts", in A. Blaszczyk and S. Rohdewald (eds), From Kebab to Cevapici Foodways in (Post)-Ottoman Europe, Wiesbaden: Harrassowitz, 162-75.

Samancı, Ö. (ed.) (2018c), Yeni Yemek Kitabı 1880, Istanbul: Çiya Yayınları.

Sancaktar, C. (2011) “The Ottoman rule and its political legacy in the Balkans", Ege Strategic Research Journal 2: 27-47.

Sauner-Nebioglu, M.H. (1995) Evolution des pratiques alimentaires en Turquie: Analyse Comparative, Berlin: Klaus Schwarz Verlag.

Sauner-Nebioglu, M.H. (2008) "The way to the hearth is through the stomach: culinary practices in contemporary Turkey", in Ö. Samanc1 and A. Bilgin (eds), Turkish Cuisine, Ankara: Ministry of Culture and Tourism, 261-79.

Şavkay,T. (1999) Osmanlı Mutfağı (Ottoman Cuisine), Istanbul: Şeker Bank KültürYayınları. Singer, A. (2011) Starting with Food: Culinary Approaches to Ottoman History, Princeton, NJ: Princeton University.

Tan, A.Ö. (2014) Güneşin ve Ateşin Tadı, Gaziantep Mutfă̆g, Istanbul: Yapı Kredi Kültür Yayınları.

Tovmasyan, T. (2004) Soframı Şen Olsun, Istanbul: Aras Yayınevi.

Whitehead, C., Bozoğlu, G. and Daugbjerg, M. "Remapping European heritage and memory," in C. Whitehead, S. Eckersley,M. Daugbjerg and G. Bozoğlu (eds), Dimensions of Heritage and Memory: Multiple Europes and the Politics of Crisis, New York: Routledge, 2019, 26-49.

Yeğen, E.M. (1946) Alaturka Alafranga Yemek Öğretimi, Istanbul: Inkılap Yayınevi.

Yenal, Z. (2003) "Istanbul'da Yemek Kültürü ve Gölgede Bıraktıkları", Istanbul 47: 98-101.

Yerasimos, M. (2002) 500 Years of Ottoman Cuisine, Istanbul: Boyut Publishing.

Zubaida, S. and Tapper, R. (eds) (1994) Culinary Cultures of the Middle East, New York: I.B. Tauris. 


\title{
Station buffets and universal exhibitions
}

\section{Places of mobility for crossing food cultures}

\author{
Jean-Pierre Williot
}

\section{Travel and the transmission of tastes}

From a review of the overarching theme of European culinary heritage in the present day and during the previous two centuries, it now seems obvious that we are considering, not a set of unchanging geographically defined situations, so much as transnational mobility. This is an essential pathway in cultural transference and the connected history of cultures. It takes different forms. International tourist mobility constantly grows as the air, road, sea and rail networks expand. Migratory mobility is prompted by geopolitical instability or the quest for work, driving people to cross frontiers at whatever risk. This may occur upon various geographical scales entailing widely diverse experiences.

The exchanges deriving from such movement often have a decisive effect on gastronomy. Tourists coming across unfamiliar products on their travels connect new tastes with the change of scenery. Migrants changing country may bring their culinary skills with them, adopt the diet of the host country, or mix and blend the two. Anthropologists have abundantly shown the extent to which such migratory processes have served to circulate cuisines and transplant tastes (Barou 2010; Kershen 2009).

All such attitudes of appropriation or rejection, brought about by geographical mobility, cause an evolution of identity. From integrating novelty to passing on one's own lifestyle, a blurring takes place between the innovation mechanism and the claims of heritage.

In insisting on the existence of solid, long-standing, staunchly defended national cultures, food heritagization tends to overlook one factor. A tradition is nothing but the sedimenting of a novelty that has gained acceptance and is itself gradually transforming. Mobility of place here plays a central role lending support to the idea of a shared European heritage. The aim of this chapter is to show its relevance when considering certain channels of food exchange in the 19th century, formed by geographical to-ing and fro-ing across Europe: the movement of people, products and gastronomic knowledge. In tackling this subject I concentrate on two main types of venue: on one hand, universal exhibitions, and, on the other, railway station restaurants which brought scope for new experience as the great European rail networks became established. 
When, in 1935, the art historian and future director of the Braidense Library in Milan published a bibliography of foreign travellers to Italy in the 19th century, he recorded more than 600 stories of English-speaking travellers, a little over 550 stories in German and more than 1,000 narrations in Italian or French (Lodovici 1934). These texts did not necessarily include descriptions of the dining table or the impressions of the travellers discovering new local cooking, but provided a considerable source of food facts. This example alone could be enough to justify a study of travelogues as an essential source of European identities and their representations applied to food history.

An example would be Angiolo Tursi, whose donation has enriched the National Library of Venice with a project to bring together the entire bibliography on travel in Italy, whatever the century (Campana 1999)! He managed to collect 60,000 cards. A bibliographic study on travelogues estimated that in the 19th century, the ever-increasing production of travel stories was accompanied by the diversification of written languages. This helped to spread the descriptions of other territories to wider audiences. These audiences were thus confronted with multiple identities that they could get to know better. Thus, while in the 16th century, $28 \%$ of travel stories were written in Latin, Greek or Hebrew, these made up less than $2 \%$ in the 18th century. But by then, there were more than 3,500 stories: 37\% in Dutch or German, 30\% in French, 25\% in English and 5\% in Italian and Spanish (Roche 2011). In the 19th century, the dissemination of stories in national languages followed the ever-increasing slope of continental mobility.

The filter of the trip is rich for our purpose. It allows us to observe food identity inheritances on multiple spatial bases. There are significant differences between local, regional, national and transnational, which travel can separate or bring together. The narrative of mobilities and their contexts thus opens broad windows on identities, inherited or modified by wandering. The testimony of the traveller can turn the observation towards the food production of a place, the specificities of a food business and the opportunities to eat and drink, whether sought or fortuitously discovered. It informs society as much as the economy, personal opinion and collective psychologies. This type of text is therefore of particular interest for us. It gives us the means to observe and describe the ways of living and being away from home.

The historiography of travel with its surges of innovation confirms that this is a fertile area for observing confluences as well as diversities (Venayre 2006). Complementary to the history of travel, the history of transport has also contributed to informing the analysis of the conditions of travellers. Whether it is the automobile, planes, shipping or railways, each mode has its historiography: plural and centred on the techniques, the economy of the companies or that of the infrastructure. As much as the journey itself, the traffic conditions are to be taken into account. They can determine the experiences and induce the representations. As such, the railway trip upset perceptions during the 19th century. 
Travel guides did not originate with the railways in the 19th century. Ottokar Reichard's A Traveller's Guide to Europe, first published in German in 1784 and then translated in French in 1793, set the tone for this necessity. Some pages were devoted to inns. Their inclusion was primarily related to the fact that they alone offered stables for rest stops. Their food function was only secondary, but it became essential, as the number of guides increased, by locating this stage between indigenous habits and the demands of travellers. A hierarchy of European routes was thus born from the signalling of journeys and associated resources. The rise of guide collections created habits even before rail became an additional means of mobility. When, in the mid-19th century, the English Murray guides, the German Baedeker and the French Joanne took decisive places for the tourist, the information given constituted a legacy of past practices for European travellers (Guilcher 2011).

If we exclude the traveller who was invited to someone's house, the one who did not plan his trip, and the individual who preferred roaming and adventure, the others found the travel guide useful. In a way, the book indicated where to go and what to do. It could be used to recommend diets and precautions against foreign cuisines, creating interest in discovering new flavours and local gastronomy (Morlier 2013, 201-31). But the pamphlets clutched by slightly nervous travellers also carried information on different places. The description of the restaurants - at least, the mention of the list with sometimes the indication of the foods most frequently served - was a reference point for many travellers. The correlation between the possible paths in a place and the arrangement of tables at different points of the city could guide and inspire. The selection, whether or not travellers followed it, was enriched with practical convenience when station buffets became an increasingly frequent offer.

As the volume of travel has grown, the emergence of new food and the competition of food places have spread. Cross-cultural territories were strategic places. The originality of a cuisine and local food production have become more profitable. This evolution was not only linked to the growth of the railways.

Ports offered multiple tables where migrants, sailors and long-term travellers could feed. The piers and docks, loaded with supplies from overseas and distant destinations, offered renewed senses, flavours, smells and appearances. Port cities, even more than the port itself, included this diversity in their economy. In Bordeaux, Caribbean rum and American sugar are strong examples. Inner harbours have contributed to the circulation of tastes (Hubert and Figeac 2006).

The road junction inn and the post office also offered random stops. However, they were not required where the products of the place could be transported further or employed in culinary ways. Road inns were not just urban. Only the most important welcomed travellers to the heart of the city. Others were simply stages in villages or small towns which saw less frequentation due to limited mobility. In their entirety, these stops on the paths were experiences that each traveller could carry as a new element of his food register. Although many testimonies seem distressing as to the foods served, they did restore the traveller. 
Some reverse the criticism. In the mid-1860s, Théophile Gautier welcomed a trip to Normandy. He had found dinner at an inn where "cold meats, ham, cider, wine and coffee" (Goulemot, Lidsky and Masseau 1997, 427) were served. Everything had pleased him.

The railway created a new obligation. The departure, like the arrival, took place at the station. The first stations were at the entrance of the city, away in the suburbs. For example, that of Antwerp was opened in 1865. The station was wedged between the park - which became a reputed zoo - and the Borgerhout's gate, a privileged way of entry into town via the crossing of the rampart walk. Gradually, the stations were surrounded by increasingly densely populated real estate. But the station remained a gateway to or from the city. It was there that the railway's first contacts with the city were made. The traveller could spend time waiting to board, a term drawn from the language of sea travel. The station and its place have become "identity cards" of the city. Before the traveller went into the city to eat from a street kitchen or be seated in a restaurant - other nodes of culinary exchange - he spent his first moments in the enclosure of the station.

To the 19th-century traveller, this entry into the city was equivalent to making a leap in the dark. The station became more familiar with the expansion of the flow of travellers and especially their diversity: tourists passing through, workers and employees in daily migrations, farmers selling to the market, military garrisons and so on. The station, which was also the place from which one left, became the heart of the space mobilities. Whether small scale, between nearby cities or announcing long journeys - Englishmen leaving for the Riviera or soldiers going to the front - the hours spent at the station made it useful for a commercial offering to be established there. Long remaining closed on itself since access was only allowed to travellers - in France until the 20th century - only the holders of a concession in the space of the station could attract a few customers. The port brewed the migrations; the inn imposed the kitchen of a place; the station engendered both.

\section{Station buffets: multiscale food exchange territories}

For the railway traveller, the two movements of departure and arrival were not experienced in a single way. Initially the station was to be a place of convenience for travel: ticket purchase, luggage registration, waiting for access to the platform. The privileged spaces were thus the places of administration of the journey and the places of waiting: halls, bookshops, restaurants. On arrival, the traveller's goal was to go out to reach his hotel or work. For the tourist, the finish yard supervised the recovery of luggage and precautions against con men of all kinds. Taking a cab to a hotel, taking the tram or going through the maze of city streets created needs not in the station, but rather outside the city.

In this context, the station buffet met the needs of departing travellers more than those who arrived. The first found the buffet service to be anticipating the 


\section{LA GARE}

\section{EST AUJOURD'HUI} CE QU'ÉTAIT AUTREFOIS
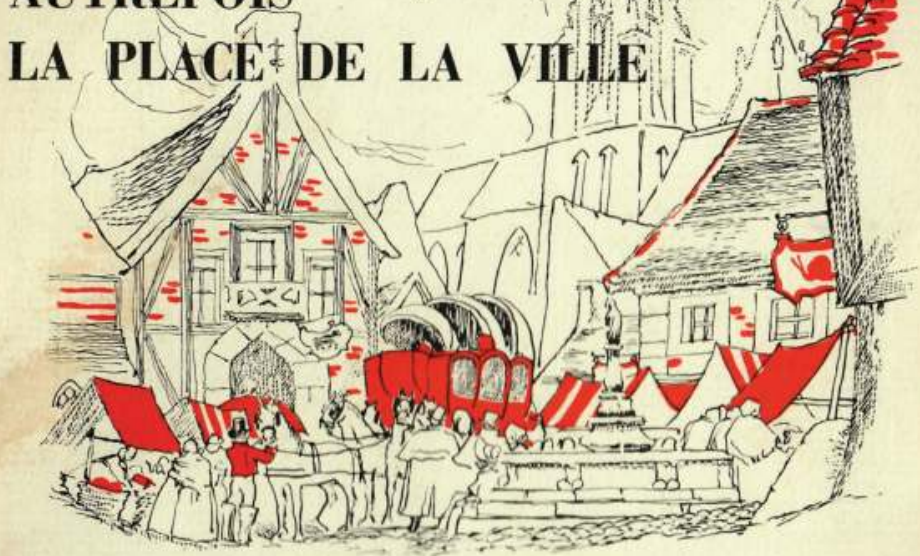

CHEMINS DE FER

DE L'ETAT

Figure 10.I Chemins de fer de l'Etat, La gare est aujourd'hui ce qu'é tait autrefois la place de la ville, Paris, Draeger imp. [1930]. Photo:Jean-Pierre Williot, with thanks to Fonds Cheminot-CCGPF Paris

journey, a place of waiting for a food function. The buffet room was also suitable for community banquets where members arrived at the station and found the ideal gathering place. With the proliferation of passenger flows and the integration of the station into the city, the station buffet has changed. It has become a more important restaurant for travellers: while remaining the place of passage for tourists, its commercial offering has extended to city dwellers.

The first station buffets were created in England and France in the 1830s and 1840s. Their multiplication proceeded mainly from the expansion of railway networks. In France, the network grew from $573 \mathrm{~km}$ in 1841 to 5,500 in 1855 and 41,000 in 1913. The commercial interest came from the growing 


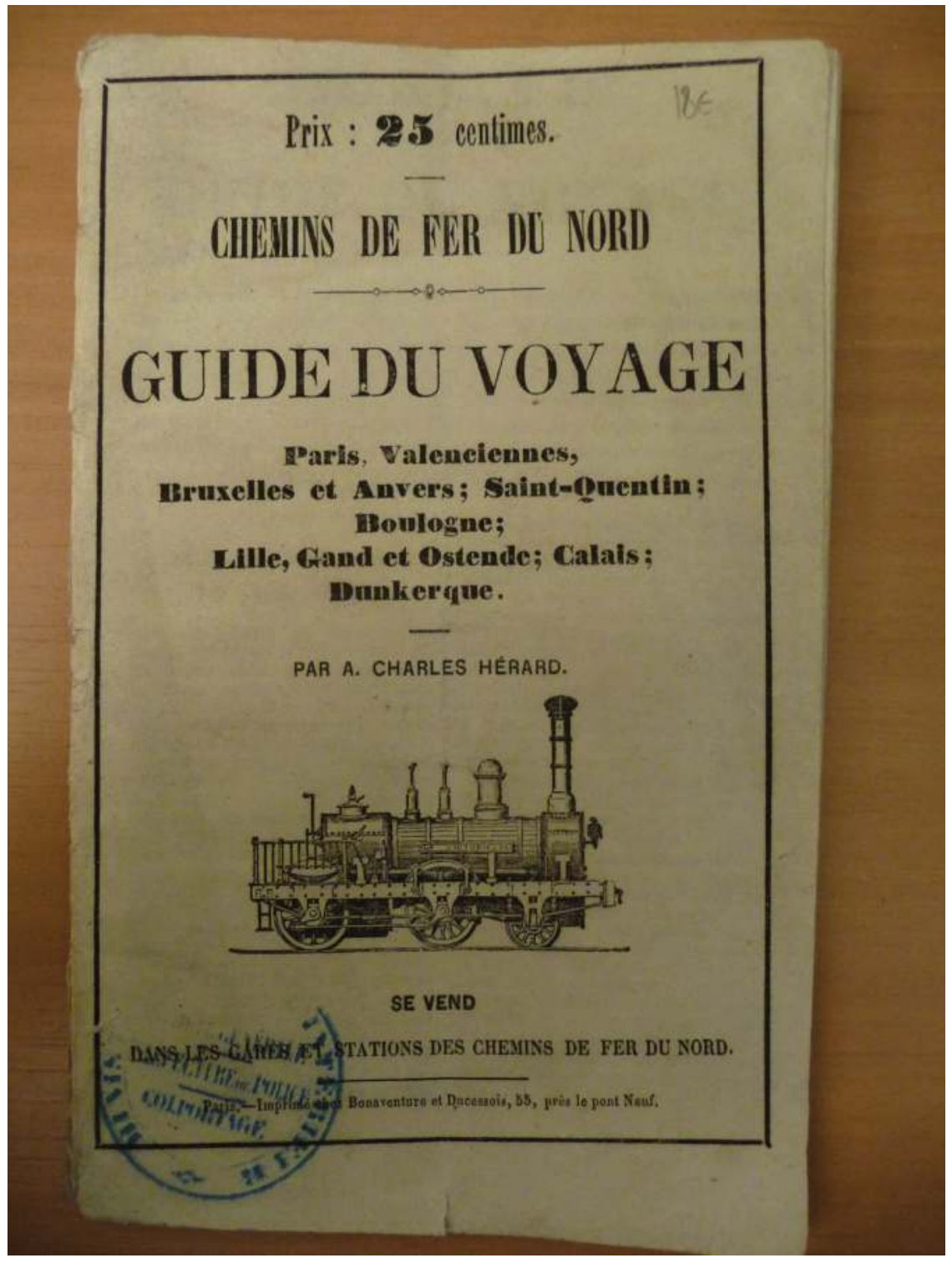

Figure 10.2 Chemins de fer du Nord, Guide du voyage, Paris, Bonaventure et Ducessois imp. [1850]. Photo: Jean-Pierre Williot, with thanks to Fonds CheminotCCGPF Paris 
number of travellers: 6 million in 1841, 131 million in 1875, 547 million in 1913. The number of station buffets increased from 66 in 1858 to 115 in 1878 (meaning that 5\% of France's stations had them), and to 445 before the First World War.

The framework therefore evolved according to the nature of the travellers and the role assigned to the station buffet. At first, it was a service designed as a provision space during the trip. Then it became a comfort lounge for a bourgeois clientele. Last but not least, the buffet station moved on to become a place of passage and capture from the crowd passing through the station. This development, which is reflected in the layout of stations, reflects the status of travellers and their typology. Some buffets showed their representation through architecture: those in Amsterdam, Milan and Antwerp reflected national identities. An emblematic example, the Zurich buffet, was inserted in the central station. It was built between 1865 and 1871 by Jakob Wanner, founder of the Zurich style at the end of the 19th century. It was inspired by the historicist style and the national style promoted by Gottfried Semper, director of the Polytechnicum in Zurich. With its architecture of a triumphal arch and ancient baths, it was one of the biggest buffets in Europe, with different salons.

The first sections of railway lines served limited distances, at low speeds, with stops made necessary by the need to recharge the locomotive with coal or water. The short duration of the journey permitted everyone to find a solution to feed themselves, often with provisions carried with them. The proliferation of judgements created a commercial opportunity. The formula of the buffet was applied literally: a counter where provisions were sold. Some were obviously local products, raw or processed. Soup, the quarter of cold poultry and fruits figured on the menu, as did culinary specialities. In England, Swindon station earned its gastronomic reputation by selling Banbury Cakes, a puff pastry made since the 16th century. The opportunity to stop for longer and enjoy a meal at the buffet appeared to catering contractors as the possible legacy of the coaching inns. Most travel stories and travel guides report shorter stops and the difficulty of having a decent meal. The American traveller Mark Twain compared the brevity of his 10-minute stop in England with the 30 minutes he had in Dijon in France (Twain 1869).

The buffetists, most of whom were originally restaurateurs attracted by the possible turnover at the station, have often innovated. Commercial choices have diversified. Some have opened bars to offer drinks near the platforms. Trolleys were set up on the platforms to pass food to travellers who could buy without leaving their carriage. The space of the buffet in the station was arranged to receive diversified clienteles. The bar was for fast consumption; the tables were for more elaborate meals. As early as the 1880 s, the first forms of automatic distribution also appeared in the stations' spaces. The German company Stollwerck took advantage of these to sell its chocolates. 
The convenience of the buffet was revealed in two types of more particular services. When an official procession was moving, the buffet could serve as a food area by dissociating the services provided. This was the case at the Lausanne buffet when the convoy of Queen Victoria of England stopped on an official trip in 1890. The buffet served as a caterer to bring the foods to the royal car, and different menus were provided for the notables of the royal suite and for the servants. At the end of the 19th century, banquets became another asset of the biggest buffets. Thanks to the catering at the station, the size of the room, the number of possible covers and the well-stocked cellar, the station buffet was a meeting point.

Another function of the station buffet was to create a market. Three steps oriented them towards the dissemination of food products, so they could develop innovation trends at regional, national and international scales. The first stage was to accept products that artisans or small sellers, such as street vendors or peasant women, could sell to supplement their income. The introduction into the station was initially limited. But it was extended either by commercial interest or on the initiative of the railway companies and the wives of railway employees.

The second stage was taken care of by the buffetists who reacted to the creation of restaurant cars from the 1880s onwards. Ready-made basket formulas, allowing travellers to feed themselves on the train without having to leave their seats, were an important innovation in the diffusion of tastes. These baskets, whose food composition might be of limited quality, could also be a commercial way to develop the notoriety of a station buffet. The case of Casali and cestino da viaggio in Cesena is exemplary. Father Casali opened the buffet in 1860, the son invented the basket in 1913 with a hot dish: a terracotta container to preserve the dish of tagliatelle al ragù, lasagne, an arrosto di pollo and vitello $e$ salsicce (pasta, chicken, veal and sausages), each cut out and presented, but also cheeses and amaretti. In France, the Capdenac buffet, offering local preserves, gave birth to the Raynal and Roquelaure canneries.

The third stage was to develop a commercial offering for tourists selling local products at the buffet. This was the most durable method and it is still found everywhere. In 1852, when the national network was barely implemented in France, maps reporting the gastronomic productions of the territories with railway lines were already being published.

Therefore, the notoriety of station buffets came from their ability to develop gastronomic menus. This was justified by the competition that restaurant cars had engendered. Fewer travellers were interested in buffets since rich food could be served directly on the train with a high level of luxury. This new situation oriented station buffets towards two different types of clientele. One method aimed at democratizing buffet meals. The other concentrated on highlighting gastronomic proposals.

From the very beginning of the station buffets, travel guides pointed out the types of services that travellers could find. The mention of buffets was only one 
element in the wider offering that could be found in the city. But this indication was an invaluable aid because it adapted to the recommendations that travel literature could address before any pilgrimage. Works on the physiology of the railways advised against eating on trains due to the risk of not digesting. The recommendation of the buffet became very useful. It was not a question of preserving travellers' health, but rather of separating behaviours between the habit of eating food served at the table, and the random way of refreshing oneself on the go, which was considered more popular. Buffets have served as transmitters of kitchens, on one hand through the discovery of culinary preparations of local food, on the other by raising their services according to the demands of travellers. Finally, these tables served as midpoints for food practices to meet, intersect or even mix.

One guide, for example, points out this suggestion, which invites us to cross social boundaries: "When you do not travel with ladies, do not disdain the dining rooms of the 3rd class, especially if you like beer; there is beer poured in glasses and not in bottles, wine of the country and dishes as good as in other rooms but cheaper" (Joanne 1900). Another, earlier guide notes the amenities that facilitate the maintenance of barriers of class or gender. The English guide Esquiros notes in 1865 that "the ladies will find at the buffets of the big stations servants of their sex to serve them" (Esquiros 1865).

The lengthening of rail networks and the development of international travel have given additional elements of comparison to travellers, who have discovered other ways in Europe and all around in the world. One example concerns a French tourist left in Asia. He evokes on a Japanese journey the game of the restaurant wagon, very different according to the different cultures:

At noon, the young gentlemen, descending to a station, are reassembled with a pretty little box in white wood. They opened it. It contained rice that they ate, very simply, with a cup of tea, which constituted all their meal. I, in the dining car, had stupidly filled my stomach with five or six enigmatic dishes, so-called Europeans, and elaborated by people who are not unaware of the worst recipes of the art of accommodating remains.

(Brieux 1914 156)

Between the travel guides' descriptions and the measure of the real that travellers' comments produce, the impressions and representations of other food cultures become well informed. These sources do not necessarily give a quantitative testimony. But the presentation of what travellers expected to eat and their judgement of what they were buying open up a perception of food exchanges. There is more or less porosity of culinary habits. Of course, the restitution would be even richer in these places of mediation if we had complaint booklets that travellers could use. In each station, customers could leave comments on the buffet about the service. Due to the lack of such 
sources, it is through the representations given by iconography, fictional literature and travel correspondence that we can draw a picture of the evolution of station buffets. These restaurants brewed very heterogeneous food knowledge on different scales depending on the traffic of the station. There was little in common between the American writer discovering the food and "civilization" at the Chartres buffet (James 1994, 140) and the French bourgeois impressed by the caviar sandwiches with a glass of chai at the Eklavi station buffet, between Batum and Baku, in the company of Russians, Armenians, Germans and Persians (Charton 1891, 376).

Through different experiments, common channels existed for the exchange of information about food. As poles of mobility, station buffets formed a favourable setting for the confluence of their products, some of which became the supports of a trade in "specialities" for tourists. They helped to spread local cuisine. They have become part of a chain of food legacies that other places of mobility have brought to global scales.

\section{The showcase of international exhibitions: a European opportunity}

The large world fairs gather different viewpoints. They are extrapolations of the rhythm of the journey. After the first national exhibitions, focused on industrial products or agricultural changes, the introduction of international exhibitions, some of them universal, opened a new space of confrontation. These exhibitions have led to economic and cultural exchanges in Europe. The first, as we know, was linked to the English will to show and demonstrate the British model of industrial development. The 1851 Great Exhibition at the Crystal Palace was long remembered. It testified to the English industrial revolution and material contributions to everyday life. It founded a new commercial framework and a scene of events.

We know of the success of the formula, which was repeated several times in Europe, while other exhibitions, considered international but not universal, offered the products and innovations of industrial civilization around the world. This was the case, for example, with the Great Exhibition of the Industry of All Nations in New York in 1853-4 or the World Columbian Exposition of Chicago in 1893. On the European continent, events with international status included the International Exhibition of Arts and Crafts in Dublin in 1874, the International Exhibition in Glasgow in 1888, the Brussels Exhibition in 1897 and the Esposizione Internazionale del Sempione in Milan in 1906. To these were added the famous exhibitions given the title of universal. Twelve of them were held in Europe between 1851 and 1914: two in London (1851, 1862), four in Paris $(1855,1867,1889,1900)$ and one each in Vienna (1873) and Barcelona (1888). The other four were held in Belgium: Antwerp (1885), Liège (1905), Brussels (1910) and Ghent (1913). 


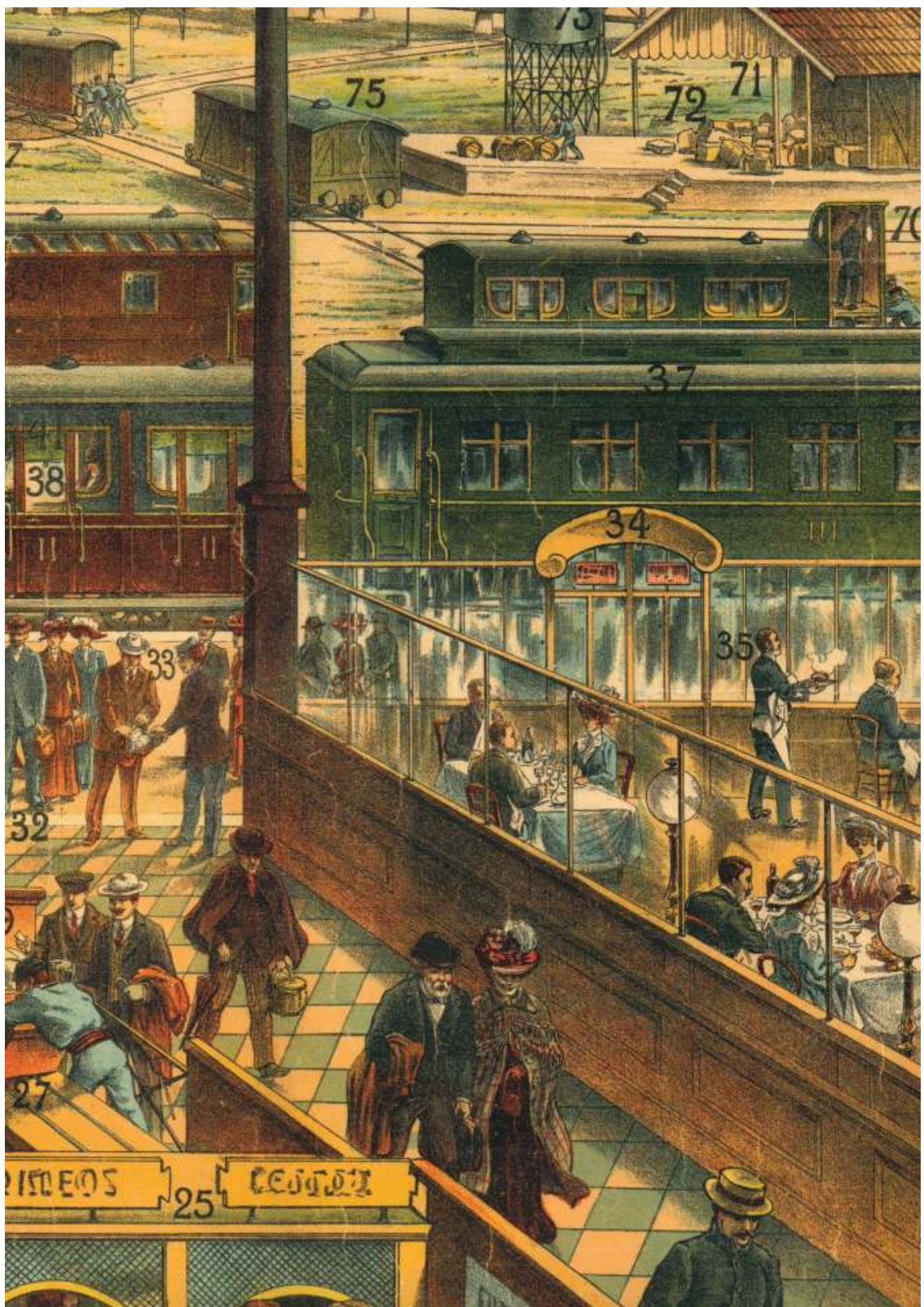

Figure 10.3 Tableau auxiliaire Delmas pour l'enseignement pratique des langues vivantes par l'image. Série III: NI2- La Gare, Delmas (G.), Bordeaux (circa 1900). Photo: Jean-Pierre Williot, with thanks to Fonds Cheminot-CCGPF Paris 
Commercial showcases designed to attract crowds are measured by statistics of spatial occupancy and the number of visits recorded or evaluated. The first exhibition in London lasted 164 days, occupied more than 10 hectares and gathered at least 14,000 different exhibitors. As for the attendance, it was estimated at 6 million admissions. In comparison, 22 years later, in the heart of the Austro-Hungarian Empire, the exhibition inVienna lasted 20 days longer, its area was 23 times larger and the number of exhibitors had quadrupled. Finally, at the end of the century in Paris in 1900, all the statistics exploded: 211 days (the longest of the century), 230 hectares divided into two poles, 83,000 objects presented and more than 50 million visitors - more than the French population, even though the organizers recognized that $23 \%$ of entries were free (Chalet-Bailhache 2008). This major international event - it was no less than a summing-up of the 19th century! - was another mobility hub. During the summer of 1900, more than 100 million travellers passed through Parisian stations, and some of them ate in a station buffet.

The exhibitions of the late 19th century differed greatly from that of 1851 . After 1867, it became the rule for national pavilions to house exhibitors as a single pavilion was no longer sufficient on this scale. Thematic pavilions followed. InVienna, one could enter a tea pavilion or that of Xeres. Later, it was the brands that in turn took possession of a territory that had become commercial. In 1889, the pavilion of the Amer Picon aperitif, created in 1837, found its position between the pavilions of India, Uganda, Senegal and the French Alliance. It was very recognizable with its mosque architecture and the bright dome to suggest trade links with Algeria. In these contexts, the space devoted to food discoveries was not limited. The exhibition was accompanied by a pedagogy of developing food exchanges.

There is little difference between the report written by a European doctor astonished by all the flavours he did not know and the memoirs that a cultivated early 20th-century woman could write after visiting the Paris Exposition of 1900. Dr Bonnafont was ecstatic about the smoked meats, lobsters, cherries and rye bread that he discovered in the station buffets during a trip to Scandinavia in 1880 (Bonnafont 1880). The Countess de Pange looked intrigued at the sacks of rice from the distant Indochinese peninsula (Broglie 1962). If the station buffet could surprise and allow for punctual food appropriation, the exoticism of a great international fair aroused ephemeral discoveries. The space of the universal exhibitions was also the meeting place of culinary cultures, real or invented (Teughels and Scholliers 2015; Van Troi 2012).

Food was eaten and eating behaviours could expand. The offer was diverse. In Vienna, for example, in 1873, the visitor went to the restaurants in the pavilions of Italy or Hungary. The variety of establishments continued to be amplified in later exhibitions. In 1878, 39 dining places were open on the grounds of the exhibition in Paris. They included four luxury restaurants, 28 buffets, some brasseries and two cheap restaurants. At the next Parisian exhibition, there were 86 dining places, both French and foreign. Generalized commodification 
became the rule; this favoured the diffusion of tastes or their confrontation. In Paris in 1889, there was the Creole restaurant, the Algerian concert café and the Moorish café next to the Annam restaurant. The publication of guides to stroll through the exhibitions showed that culinary cultures did not mix so easily. The visiting public was thus prepared for false signs in the form of weird sauces and unusual recipes: the exhibition could also be a territory of exchange and deception.

Sometimes, at the margins of the events or to attract the public in other ways, ceremonies and banquets opened different scenes. Regional cuisines found political platforms. The organizations of cooks made them a vector of additional events. Thus, culinary exhibitions were added to the fairs in London as early as 1851 and to the fairs in Paris that followed, before becoming autonomous performances. Between demonstrations of know-how, political affirmation and staging of a national gastronomy, these exhibitions also contributed to exchanges by reinterpretation or by copying.

Beyond the consumption that visitors could experiment with as a source of food crossing, the real stakes of the exhibitions were in the commercial competitions. Three forms of competition could be involved: each was a way to spread innovation.

The pavilions favoured the presentation of the food products to be made known (Saillard 2012, 71-84). The classification of Bordeaux wines in 1855 had already had the objective of selecting products to promote their commercialization. The absence of a delegation revealed other objectives, sometimes not to participate in the game of competition. So, when the tinned-sardine firms of Vendée and Brittany refused to bring their products to the exhibition in St. Louis in the United States, their places were taken by others. The French considered other competitors of lower rank. However, the Portuguese canners found advantages in the promotion of their fabrications. Some societies understood this well when they had the right to promote their brands, for example Maggi or Liebig demonstrating their food innovations. Others, such as some English bakery machine builders who asserted their presence in 1889, aimed to demonstrate their techniques, which could be exported to foreign countries. Some brands or corporations stuck to the impression, to the point of the show, for example Mercier and his giant champagne lightning can, which contained 120,000 bottles, at his house. Another example would be the pastry chefs who in 1900 managed to provide a gingerbread of five metres in length.

Conferences bringing together experts - whether industrial, scientific or technical - made it possible to discuss the evolution of a sector or a food chain. During the 1878 exhibition in Paris, the international brewers' congress and the dairy industry congress were important moments in the structuring of commercial exchanges and transfers of technology. At the time of these congresses, the board of members was an international meeting. Also, the organization of debates and conferences was both an exercise in transnational cooperation and 
an assertion of dominant positions. The brewers' congress was attended by six vice presidents: two Frenchmen and one each from Philadelphia, Copenhagen, Sydney and Spain. The English and Belgians were only secretaries of the congress.

Medals and awards were important in the acquisition of notoriety. Far from being honorific attributes, they helped to extend the winners' reputations among consumers. They had been able to discover the products at the show and they could see the fashions spread. More than 5,000 prizes were awarded in London in 1851, more than 25,000 in Vienna in 1873 and almost 46,000 in Paris at the turn of the century. Being on the distribution board of awards was not just an honour, it was a strategic position with regard to sectoral economic issues, one which could be directed to the advantage of a particular country.

Through their propensity to showcase evolutions and innovations, the world exhibitions thus helped to promote national food industries. They also circulated new knowledge and practices. In 1867, an exemplary proof of circulation and exchanges in Europe was thus provided by the French cheese industry. France has generally produced only fat cheeses, difficult to transport and preserve, while Holland, Switzerland and England produce considerable quantities of firm cheeses that are long-lasting and survive long-distance journeys. Other examples of creation associated with the large exhibition shows served other purposes, such as the Belgian waffle, which ceased to be only made in Liège. As such, mobilizing visitors, many of whom were also travellers, contributed to the dynamics of food exchanges. The confrontations with products and kitchens considered typical or traditional led to renewed food appropriations through these channels of products and human mobility.

Finally, we must emphasize how universal exhibitions served as platforms to publicize national productions or to show the similarities of food in Europe. In groups or classes, each exhibition presented the products associated with evolutions in cereals, agriculture, livestock and fisheries, and systematically the products resulting from artisanal processing or industrial creation. Pastry, confectionery, preserves, biscuits, pasta, coffee, teas, chocolates, beers, wines and spirits, cured meats, butters, cheeses and fats constituted a long list of goods.

To confirm this, we can consider one example from each exhibition held in France. In 1867, the Paris exhibition presented different types of pasta: from Italy and France, but also from Turkey and Tunisia. An invention of pasta made with rice flour, which cost less than wheat pasta, was part of the French exhibition. This was stained with powdered turmeric to make it acceptable to the consumer.

In 1889, the liqueurs section was still classified with confectionery products. The use of liqueurs had long remained the preserve of the confectioner. But since the 1840 s, liqueurs had tended to become an autonomous industry with an increasingly wide market. The commission in charge of examining the products tasted the manufactures of 396 foreign exhibitors and 302 French exhibitors. The largest number came from Algeria (62 exhibitors). In contrast, only one English exhibitor and one from the United States were present. Switzerland 
had sent 24 presentations, much fewer than the 54 Spanish exhibitors. Holland, like Italy, had hired about 15, a little more than the Belgians and the Portuguese, who scarcely passed 10. In total, aside from France, 38\% of European houses were present. It was then possible to taste a syrup of blueberries from Norway; curaçao from Amsterdam; a Swedish arac made from plants from Dutch colonies; malaga, sherry and anise from Spain; Swiss absinthes; and a lemon balm of Romanian melissa.

In 1900, the canning section proved that this important industry was now one of the common characteristics of the food industries in Europe. Among the products were Westphalian hams boxed for export, Austrian potato flour, Belgian oil sprats for industrial and working-class cities, Breton sardines in competition with Portuguese sardines, Bosnian plums, canned anchovies from Cadiz, Neapolitan tomatoes and Norwegian fishmeal cookies.

\section{Conclusion}

Travellers testify by their stories of the discovery and the transmission of new tastes, but also by their representations. After those who report their own wandering, or those who evoke the particular atmosphere of a port, all those who travel by rail leave multiple comments in which food is never absent. Their scale is that of the individual. Commercial nodes emerge at the crossroads of the trip. These are distribution platforms, generating shared identities. The station is thus a central place, as was the coaching inn. Lands of meetings, departure and arrival, stations accumulate individual routes into a collective. The creation of station buffets has focused a culinary economy. On another scale, universal and international exhibitions, of which Europe had the greatest number of manifestations before the 20th century, offer a wider scene of similar travel movements. These played the role of huge stations where there were travellers, national actors, tourists and finally future consumers. At such a scale, observation became transnational for a wide audience.

From the individual narrative of the journey, to other horizons, to the experience of a world tour, each of these processes has crossed identities. None prevented the maintenance of national interests. But these exchanges have built a common legacy in Europe, whose food is an essential part of its economy.

Over the very long historical term, these phenomena invite us to rethink the materiality of heritage transmission. Whether it is the overseas trade flows that have conditioned European food consumption, or the trade circuits born of economic globalization, food is made up of transfers and innovations in taste. To evoke a cultural heritage in countries or regions is not meaningless. But in considering the space of Europeans, it would be more relevant not to focus too much on the "national heritages" whose transmission would be proof of the stability of inheritances. The food products that result from agricultural activity and livestock or artisanal ways actually circulate in various forms. 
Linguistics accounts for this in the etymology of the names of food products. Culinary recipes provide further evidence of similarities that do not stop at cartographic boundaries. Trade, finally, supports the shipment of products that become "local" in their denomination by the paradoxical fact that they are no longer consumed only at their place of production. If there is no "European diet", there is a diet of Europeans, with differences but also a number of similarities and common features. Mobility is the key to this process - mobility of traded products, mobility of Europeans themselves and the circulation of ideas and cultures.

\section{References}

Barou, J. (2010) "Alimentation et migration: une relation révélatrice", Hommes et Migrations 1283: 6-10.

Bonnafont, J.-P. (1880) L'Europe en Train Rapide, vol. 2, Europe centrale et septentrionale, Paris: Dentu.

Brieux, E. (1914) Au Japon par Java, la Chine, la Corée: Nouvelles d'un Touriste, Paris: Delagrave.

de Broglie, P. (1962) Comment j’ai vu 1900, Paris: Grasset.

Campana, C. (1999) "Le Fonds Angiolo Tursi de la Bibliothèque Nationale de Venise", in M.Viallon (ed.), Voyages de Bibliothèques, Saint Etienne: Publications de l'Université de Saint Etienne.

Chalet-Bailhache, I. (ed.) (2008) Paris et ses Expositions Universelles. Architectures, 18551937, Paris: Editions du patrimoine.

Charton, E. (1891) Le Tour du Monde. Nouveau Journal des Voyages Fondé par Edouard Charton, Paris: Hachette.

Goulemot, J.-M. Lidsky, P. and Masseau, D. (1997) Le Voyage en France, Paris: Robert Laffont.

Guilcher, G. (2011), "Les guides européens et leurs auteurs: clés de lecture”, in "Le patrimoine des guides: lectures de l'espace urbain européen”, In Situ 15. http://insitu. revues.org/499

Guide Joanne (1900) L'Allemagne Septentrionale, Paris: Hachette.

Guide Esquiros (1865) Angleterre, Paris: Hachette.

Hubert, A. and Figeac, M. (2006) La table des ports. Cuisine et société à Bordeaux et dans les villes portuaires, Pessac: Presses Universitaires de Bordeaux.

James, H. (1994) Esquisses Parisiennes, Paris: La Différence.

Kershen, A.J. (2009) "Food in the British immigrant experience", Food \& History 7(1): 211-24.

Lodovici, S. (1934) Bibliografia di Viaggiatori Stranieri in Italia nel Secolo XIX, Rome.

Morlier, H. (2013) "Hygiène alimentaire ou goût du terroir? La gastronomie dans les guides de voyage (1850-1940)", in J.-Y.Andrieux and P. Harismendy (eds), L'Assiette du Touriste. Le Goût de l'Authentique, Rennes: Presses Universitaires de Rennes, 201-31.

Reichard, O. (1784) Handbuch für Reisende aus allen Ständen, nebst B. Wey Postkarten zur grossen Reise durch Europa von Frankreich nach Engelland und einer Karte von der Schweiz und den Gletschern von Faucigny, Leipzig: Weygand. 
Roche, D. (2011) Les Circulations dans l'Europe Moderne: XVIIe-XVIIIe Siècle, Paris: Fayard.

Saillard, D. (2012) “L'artification du culinaire par les expositions (1851-1939)!”, Sociétés et Représentations 34(2): 71-84.

Teughels, N. and Scholliers, P. (2015) A Taste of Progress: Food at International and World Exhibitions in the Nineteenth and Twentieth Centuries, London: Routledge.

Twain, M. (1869) The Innocent Abroad. https://ebooks.adelaide.edu.au/t/twain/mark/ innocents/chapter12.html

Van Troi, T. (2012) Manger et Boire aux Expositions Universelles. Paris, 1889, 1900, Rennes: Presses Universitaires de Rennes.

Venayre, S. (ed.) (2006) Le Siècle du Voyage, Sociétés et Représentations. Issue 21. Paris: CREHESS. 


\title{
Canteens, cafés and cabarets \\ The food culture of the Russian diaspora in Shanghai, 1920-1950
}

\author{
Katya Knyazeva
}

\section{Introduction}

The history of the Russian diaspora in Shanghai in the first half of the 20th century is still an emerging field of inquiry. While a significant number of studies within and outside of China have sufficiently covered the issues of identity, displacement and cultural cross-pollination, they have largely neglected the mundane and material components of the diaspora experience. The existing scholarship in English, Russian and Chinese (Khisamutdinov 2010; Ristaino 2003; Sharonova 2015; Wang 1993) only paints a general picture. There is a paucity of scholarly work covering all aspects of the half-century-long cultural and political interplay that conditioned the Russian experience in China, and specifically in Shanghai. Food culture is part of a broader discourse on local history, and accounts of restaurants, kitchens, markets and hospitality venues provide a savoury method of extricating the story of the diaspora from nationcentred or migration-centred narratives, providing alternatives to linear history (Swislocki 2008, 17-18).

Shanghai's rise to prosperity and its conscious embrace of cosmopolitanism have always been associated with its fortuitous location at the mouth of the Yangtze River, which linked the city at once to the country's interior and the wider transoceanic world. In the aftermath of the Opium Wars and China's forced entry into global trade, new commercial opportunities made possible by Shanghai's location had attracted merchants from all over China and all over the world. Sojourners in the treaty port brought with them the specialty foods and foodways of their native places, endowing the city with a diverse urban gastronomic culture and "turning Shanghai into a national and international culinary marketplace" (Swislocki 2008, 143). This was evident in the city's diverse restaurant industry that helped to cement Shanghai's status as the forerunner of culinary internationalism in China.

The exposure to Western food led to the adoption and incorporation of Western cooking into the Chinese diet. By the end of the 19th century, Western-style eateries in Shanghai were "as numerous as trees in the forest" (Swislocki 2008, 126), housed in Western-style buildings and using Western-style 
ingredients, which led the local press to argue that Western-style restaurants were "beacons of the new stage of civilization" (Swislocki 2008, 126). In the early years of the 20th century Western fare remained an important component of the idea of Shanghai, but "the burgeoning interest in the varieties of regional Chinese food-ways and specialty foodstuffs" eclipsed "the late-Qing craze for Western food" (Swislocki 2008, 143). The emergence of culinary and hospitality practices brought by Russians reignited the local Chinese interest in international food, weaving the appreciation of European cuisine into the system of status relations among Shanghai's urban Chinese. Cultural patronage and connoisseurship - and simply a broader palate among the locals - were forerunners of the globalization of the Chinese city and the rising thirst for "the modern" amid Chinese society at large.

\section{Ethnic food production in a cosmopolitan city}

Communities of Russian refugees began to form in cities across the world after the October Revolution of 1917. Most of their destinations - Berlin, Paris, Riga, New York and Shanghai - already hosted small communities of Russian expatriates, so the newcomers confronted various presuppositions about the Russian Empire and its people. Prior to the mass arrivals of exiles, the image of "the Russian" in Paris was largely cultural, widely influenced by Diagilev's ballet and opera productions from 1909 onwards, which helped to place Russianness "in the context of modernist painting, stage design, music and contemporary discourse on orientalism and refined eroticism" (Bulgakova 2005, 212). In contrast, Shanghai received a rather unfavourable early impression of citizens of the Russian Empire, when in August 1904 the cruiser Askold, damaged in the Russo-Japanese War, took refuge in Shanghai, and several hundred sailors and military personnel disembarked and stayed in the city (Knyazeva 2017, 23). They quickly entered the crime columns of Shanghai's English-language newspapers with charges of drunkenness, disorderly conduct, knife assaults and solicitation (North-China Herald and Supreme Court \& Consular Gazette, hereafter NCH, 20 January 1905, 141; 29 September 1905, 740; 3 November 1905, 243).

At that time Shanghai was a city of more than 1 million people (Wasserstrom 2009,3). It was divided into three separate administrations - the Chinese municipality, the self-governed International Settlement and the French Concession under the governance of the French Consul General. The overwhelming majority of residents in all three districts were Chinese, with a total of about 12,000 foreigners composed largely of British, Japanese, Portuguese, American and French (Directory \& Chronicle for China, hereafter Directory, 1905, 835). Some 50 Russians did not depart with the Askold after the end of the RussoJapanese War; instead, they settled in Shanghai, adding to a mix that included an earlier group of expatriates from Russia - Ashkenazi Jews, who had been doing business in Shanghai since the 1870s, having travelled the long way from the 
western borders of the Russian Empire (Ristaino 2003, 23). Numbering fewer than 100 families, the Russian Ashkenazi were close to the long-established and wealthy Sephardim community, although they shared the cultural background, place of origin and language of the Russians.

A number of Russian Jewish expatriates were proprietors or employees of hotels and restaurants in the port area, many positions being held by women. In March 1905 Jewish recruits of the Askold, numbering 32, were treated to a banquet in Mrs A. Sterling's New Traveler's Hotel; the hotel advertised its "first class cuisine" on the pages of the Shanghai-published Israel's Messenger (Israel's Messenger, 24 March 1905, 317). Mrs Frida Perlman's New Camp Hotel advertised its "scenic setting with a view of the river"; it was located near the port and offered "lodging, entertainment, wines and liquors", as well as "meals at all hours", which included "dinners, tiffins for parties" (Israel's Messenger, 24 March 1905, 318). Mrs C. Katz owned the Cosmopolitan Hotel (NCH, 4 May 1906, 242); F. Whitgob operated the International Bakery, which offered "first class cakes, bread and pastry" (Israel's Messenger, 7 April 1905, 334).

Another restaurant and hotel in the north of the city was H. M. Silkiss' Tivoli, on Boone Road; it had "nicely furnished rooms" and "excellent cuisine" (NCH, 14 April 1905, 72). The owner had the respectable status of a ratepayer (taxpayer) in the International Settlement, proof of being well off and entitled to vote on the affairs of the Municipal Council. However, he also featured in criminal reports on several occasions: in 1906 Silkiss was arrested and put on trial for burning down his own home and restaurant to receive the insurance payment. Unable to arrive at a criminal judgement against a reputable businessman, the Court of the International Settlement sent the case to Vladivostok and released Silkiss on bail (NCH, 14 July 1906, 619).

Mr Silkiss' competitor, Mrs S. Gabay, ran Olympia Restaurant on Broadway, in the row of houses stretching behind the oldest foreign-owned hotel, Astor House. Her establishment proved more abiding and resilient. In 1938 an eatery of the same name operated at the same location on Broadway, "in a line of roofless and floorless shops" damaged by explosions and fires from the Japanese air raids a year earlier. The visitors to Olympia were treated to "a plate of borscht, a traditional Russian soup made from red beets, potatoes, cabbage, meat and a final addition of French cream", followed by "a big tureen filled with frankfurters floating in pink hot water and a generous helping of potato salad" (Eisfelder 2004, 18). Guests noted that the traditional Russian bread drink, kvass, resembled plain lemonade.

Russian and Jewish cuisines were, of course, nearly identical, coming from the same regions and cooked with the same ingredients: herring, onions, tvorog (pot cheese), sour cream, potatoes, cabbage and beets (Nakhimovsky 2006, 64). Jellied meat, chicken soup, stuffed fish, stuffed cabbage leaves and blintzes were well known to both groups, although somewhat less popular with the Slavs. Many cooking patterns were shared as well: foods were rarely served whole, meats were chopped and made into meatballs and stuffing, and there was a large 
variety of variously named dumplings. Though the precise menus of the early Jewish-Russian restaurants in Shanghai are unavailable, one can speculate that since they claimed to serve "first class cuisine", they must have toned down the pungent flavours traditionally associated with homemade Jewish fare in Russia, specifically garlic and onion (Nakhimovsky 2006, 67).

On the cusp of the mass arrival of Russians in Shanghai, a 1918 city guide recorded 18 Western-style restaurants and one coffee house (Shanghai Zhinan $1918,123)$. The next year, another coffee house, a tearoom and a pastry store opened on Broadway (Zhiganov 1936, 155), in the same row of establishments as Mrs Gabay's Olympia Restaurant. Its owner, L. Winikoff, sold it in 1926 to the Russian Greek entrepreneur Kyriaco Dimitriades, who renamed it the Astoria Confectionary and Tearoom and employed a team of Chinese cooks to work under the direction of a Russian pastry chef. Astoria made its name by its "buns and bread loaves, caramels, candy and delicious French and Russian cakes with lovely sounding names - milles feuilles, cream puffs, hazelnut slices, palmiers, cream horns - and madly extravagant wedding cakes" (Skillen 2014). According to Dimitriades' daughter, "the clientele was as eclectic as old Shanghai: journalists with offices in Broadway Mansions, diplomats from the neighbouring Soviet Embassy and the British Consulate, Astor House residents, members of the nearby Hongkou Jewish community, Greek merchant sailors doing the regular cargo run and, after 1937, the occupying Japanese forces" (Skillen 2014).

The earliest grocery store catering specifically to Russian clientele emerged in 1907 and remained the only provider of sausages, salted herring and vodka until the 1920s. The owner, Isaac Shainin, had travelled to Shanghai from Odessa, and "with a capital of only 300 dollars opened the first Russian grocery in Shanghai" (Zhiganov 1936, 155), called the Russian Provision Store. Shainin's company grew through the years, and by the 1930s he owned a chain of wine and food stores called Home of Delicatessen, a liquor factory and a wholesale food products warehouse. Russian-style food staples were shipped from Harbin, but the political situation had been volatile since the emergence of the Japanese military threat and the upheaval in the Soviet Union. In 1920 Efimoff's Liquor Distillery in Shanghai began to supply vodka to the Russian tables, although not in the quantities required by the growing population; the press complained that in 1925 "there was no local vodka and no canned zakuskas other than cheap sardines in tomato sauce, while Moscow sausage from Harbin cost an arm and a leg" (Shanghai Zaria, 22 April 1930).

By the early 1920s Shanghai's Russian community was established and growing, clustering in the vicinity of its point of arrival, the city port. Although the community was mostly poor, it was entrepreneurial, and many new arrivals possessed enough capital to start a business. In May 1920 the experienced restaurateur Vassily Shouin, who had owned restaurants in Russia's Far East and Harbin for almost 30 years, opened the Grand Restaurant St George in Shanghai's International Settlement. Advertisements for the venue extolled "the 
celebrated old Shouin's culinary genius" and offered "luncheons, teas, dinners, suppers, high class in every respect" (Shanghai Gazette, 6 August 1920, 3). There was no special emphasis on the ethnic character of the food, but rather on the wealth of entertainment options, from a symphony orchestra, "the best jazz band" and "zestful dance music" to accompany the daily afternoon "thé dansant" (Shanghai Times, 13 May 1920, 12). The St George also held raffles, a popular type of lottery the proceeds of which ostensibly went to a designated charity; Russian refugees often featured as the beneficiaries. In spite of the large capital investment and lavish advertising, Shouin's restaurant went bankrupt in three months, and by August 1920 creditors and the landlord were pursuing the owner (Shanghai Times, 4 August 1920,2). Shouin never operated a high-profile restaurant again, but the equal weight given to entertainment and eating set a pattern that became the most persistent characteristic of Russian establishments in Shanghai.

The failure of Shouin's establishment was probably due to poor timing. When the St George opened, Shanghai's directory listed only three restaurants of comparable scale, the Astor, Carlton and Palace Gardens (Directory, 1920), and they, presumably, were enough to cater for the needs of the moneyed community, represented by foreigners who counted about 23,000 (more than a third of whom were Japanese). Nevertheless, by the end of the 1920s more than 40 Russian restaurants were operating in the city (Liao 2014), and Shanghai's foreign and Chinese public was more receptive to new ventures. By the 1930s the Russian community numbered about 20,000 people, and the majority lived in the French Concession and the International Settlement, the centres of purchasing activity.

In the decade between 1927 and 1937 the city saw explosive economic growth and on the whole enjoyed relative political stability, with a Republican government based in nearby Nanjing. There was, however, localized urban conflict in the port area, as government forces pushed out factions loyal to the local warlords. Stateless Russians were vulnerable and frequently attacked, and so they moved to cheaper undeveloped areas under French jurisdiction west of the city. At the beginning of their migration to the French Concession in the late 1920s Russians considered the area rural and undeveloped, and journalists described the central French Concession as a wasteland and an "Arabian desert", "with low squat bungalows" (Muratov 1934) lining the dusty track of Avenue Joffre, the main thoroughfare. It was the entrepreneurial flair of Russian small business, particularly grocers and restaurateurs, that succeeded in transforming this area into the most fashionable and thriving part of Shanghai.

One of the factors that led to this strong Russian entrepreneurism was the social and professional composition of the diaspora. Former subjects of the Russian Empire who ended up in China originated mostly from Siberia and the Far East, and in contrast to Paris, where a large diaspora was taking shape in parallel to Shanghai, the majority of exiles in China were merchants, skilled workers, teachers, journalists, petty officials and clerks (Wang 1993, 32). Conversely, the aristocracy, large-scale manufacturers and state officials formed 
an insignificant part of the community. Women comprised almost half of the Shanghai diaspora, and became a workforce on a par with men, going into business in unprecedented numbers, driven mostly by the need to provide for their families.

Russian merchant activity was also enabled by the laissez-faire land and credit conditions in Shanghai. It was easy to obtain a loan from a Chinese bank or a credit society. In the words of V. Fedoulenko, the owner of the first pharmacy in the French Concession, "the condition was that everything must be paid within one year; if you didn't pay within one year then you never got any more credit. If you did pay back within one year then you had complete respect and you had all the money you ever needed" (Fedoulenko and Raymond 1978, 53). Impending repayment of loans explains the tendency of Russian businesses to go bankrupt around the one-year mark. "Many of our merchants who gave the appearance of being very wealthy were in fact quite poor but lived and operated on credit" (Fedoulenko and Raymond 1978, 84). Forty-five-yearold F. G. Potemko, the owner of the Imperial Hotel and Restaurant and a string of other large restaurants, had seen every one of his enterprises become a business failure. In 1934, while making plans to open yet another restaurant in the French Concession, he ran into financial problems and wrote a suicide note indicating his intention to drown himself. Potemko's body was never found (The China Press, hereafter TCP, 1 October 1934, 8).

Entertainment palaces like the St George were costly to open and to maintain, and some restaurateurs found it impossible to face their creditors. Eventually, it was less capital-intensive, smaller enterprises that became the dominant economic entity in Russian Shanghai. Restaurants, tearooms, cafés, cabarets, canteens, nightclubs and bars were housed in popular two-story row houses, standalone villas or makeshift pavilions. Food retail enterprises, such as dairy stores, deli shops, liquor stores, bakeries, groceries and confectionaries, had an even longer average lifespan, and were able to resist market fluctuations thanks to being rooted in the unwavering demand of the resident Russian population.

As an urban setting, the French Concession compared favourably with other areas of Shanghai by the small scale of its urban fabric, lax business regulations and potential for growth and densification. While the Chinese-governed territories surrounding the foreign settlements had cheaper rents, they offered less safety. The port area and the northern districts of the city where Russians lived in the 1920s became the site of urban warfare twice in five years, in 1927 and in 1932. The clientele for the Russian food businesses was mostly themselves and other Westerners living exclusively in the settlements. The International Settlement was harder to penetrate as it consisted either of high-rent business blocks that precluded Russian small businesses from thriving or of residential suburbs with a low-density population. By contrast, the French Concession had the infrastructure and the street frontage that held just the right kind of potential for a vibrant commercial scene and a service economy.

One of the most impactful enterprises on Avenue Joffre, the main boulevard of the French Concession, was the café and restaurant of the brothers 
Tkachenko, which opened in December 1928. Its emergence marked the centre of the zone where in subsequent years a multitude of Russian businesses would thrive. The Tkachenkos' café offered a "splendid selection of fresh cakes, pastries, chocolate and candies", as well as "ice cream, wines and refreshments" (TCP, 23 June 1929, 6). It was open until 2:00 Am, in stark contrast with the dormant scene in the residential French Concession. The customers were, reportedly, a mix of Westerners, among whom there were "financial and administrative elites, diplomats and ordinary Russian emigrants" (Zhiganov 1936, 186). Entertainment was more than a vital part of the dining experience at Tkachenkos' - it was, in fact, the raison d'ettre of the place. The programme of concerts, comedy routines and theatrical performances on the stage in the dining room changed biweekly. The audience had an option of paying a reduced price and attending only the show without the dinner (Zhiganov 1936,186).

Performance routines rotated seasonally, and winter was punctuated with a string of dinner parties, from the secular New Year through Orthodox Christmas to the pagan Feast of the End of Winter (Maslennitsa), and each of them commanded a designated line-up of orchestra musicians, stage dancers and performers. The New Year celebration was the biggest event of the year and called for an extra spectacular revue that included the Cossacks' Chorus, circus acrobats and classical opera and ballet numbers. St Tatiana's Day on 25 January 1930 called for a Grand Masquerade Ball, at which the floor was thrown open to paying patrons to compete for ballroom prizes (NCH, 23 January 1931, 10). In August 1930, a "big symphonic concert" saw 50 musicians on the restaurant stage (NCH, 10 August 1930,3). In the intervals between numbers the in-house orchestra played jazz. In between calendar holidays, the restaurant was the venue for charity balls, cabaret revues and private parties for Chinese and Western dignitaries.

In summer, newspapers published the rankings of public spaces with openair terraces, and the garden of Tkachenkos' (and its later incarnations) always won a mention. In summer 1930 the brothers refurbished their garden mansion and reopened it as Piccadilly, which was reviewed in the largest Russian newspaper, the Shanghai Zaria:

On Saturday evening, the opening [...] attracted a big crowd. By 11 at night all the tables were full. Many visitors foxtrotted on the dance floors until dawn. The orchestra has a mixed profile: there are Russians, Filipinos and one black musician. They have achieved a harmonious sound that makes dancing very easy.The lanterns in the garden are hung low over the tables, keeping the dinner tables well-lit and the rest of the garden intriguingly dark and conducive of foxtrot. The kitchen is well equipped. The only complaint the public had was that the servants were not sufficiently trained.

(Shanghai Zaria, 10 July 1930) 
The next May the brothers expanded the open-air seating to 150 tables. After reopening the garden restaurant dropped Piccadilly from its name and returned to being called Tkachenkos', claiming to be "the only open-air family place in town" (NCH, 13 June 1931, 8). Indeed, compared with emerging emporiums like the Casanova and Moon Palace that advertised adult entertainment and "girls of all nationalities [...] you will be satisfied" (NCH, 27 June 1931, 5), Tkachenkos' seemed to offer a prudish kind of leisure. In summer the brothers operated a summer café on Minhang Beach, ferrying families and children "away from the madding crowd" by a specially chartered bus (NCH, 27 June 1931, 5). In November the ballroom was refurbished again, and new lights, a dance floor and decorations were installed. The kitchen was now advertising Caucasian cuisine under the supervision of a Turkish chef. The concert programme included jazz, violin solos, dance numbers and gypsy songs.

In December 1932 the court ordered the doors of the Tkachenkos' restaurant to be sealed, forcing some 40 customers to leave their plates with hors d'oeuvre unfinished. This was the beginning of a legal battle between the brothers Tkachenko and their suppliers and lenders, which in the end led to closure of the restaurant in June 1933. In August that year, the restaurant's new owner, the Tkachenkos' former assistant (comprador) Tsai Ching Dao, reopened it as the Alcazar, under the management of N. Lalin, who had made his name managing restaurants and hotels in Harbin and Mukden. Nothing in the cuisine, service or entertainment of Alcazar was substantially different from Tkachenkos'. When a year and a half later the Alcazar closed down too, the Joffre Garden opened in its place. Altogether, the garden restaurant started by the brothers Tkachenko changed hands five times in five years, which was by no means exceptional. La Maison Omon on Avenue Joffre, a self-proclaimed "restaurant de luxe" and the "best Russian restaurant in town", had Russian and "other popular foreign dishes" (TCP, 21 September 1935, 3) on the menu and a three-piece string orchestra playing in the background. Predictably, Omon opened in November 1934 and closed in early 1936.

While market demand, financial pressure and municipal regulations partly explained the high turnover of Russian businesses, additional stress was provided by the unstable political situation in the region which at times affected the settlements. Though establishment of the Republican government in Nanking in 1928 heralded a relatively stable and affluent decade for Shanghai residents, this period was punctuated by unsettling events - among them the 1929 influx of Russians from Manchuria, Japanese military incursions into the city territory in 1932 and impending armed conflict with Japan that finally burst out in 1937. All this led to a speeded-up pace of life and a kind of apolitical fatalism among all groups of the population, which stimulated the growth of entertainment and the leisure and pleasure industries. The lines between cabarets, ballrooms, nightclubs and restaurants grew increasingly blurred. Any cabaret with a stage show maintained a kitchen offering dinners à la carte; any restaurant had a resident or hired orchestra; most venues had a dance floor and 
hired taxi dancers to keep patrons company at the table and egg them on to pay for drinks.

\section{The Russian menu in Shanghai}

The Russian culinary culture in Shanghai drew its inspiration and imported business models from Harbin, where an established expatriate community had existed since the turn of the 20th century. As of 1907, even the railway restaurant, where "hundreds of people of all classes" ate every day, was "furnished with great mirrors and costly marble work" (NCH, 5 April 1907, 33). By 1923 about 100,000 Russians lived in Harbin (NCH, 17 February 1923, 439). There were "five moving picture theatres, two of which are part vaudeville, and three winter gardens [...] where restaurants are maintained" (NCH, 17 February 1923, 439). The exact number of restaurants was not known, but according to an observation by a Western visitor, "about every third entrance of Pristan" (the central district of Harbin) had a restaurant sign (Gilbert 1929, 127).

A typical meal in a high-end Russian restaurant in Harbin was dominated by "lavish portions" of hors d'oeuvres - "salads, pickles, cold meats and sausages, fresh black caviar, cold lobster, cold crab, smoked salmon" ( $\mathrm{NCH}$, 19 January 1929, 127). They were accompanied by "the inevitable little decanter of vodka which later appears only the small item on the bill" (NCH, 19 January 1929, 127). Because of the habit of pairing starters with alcohol, hors d'oeuvres were referred to as zakouskas even by English speakers (the Russian word means specifically "food to chase down liquor"). After a plentiful course of zakouskas, the "mediocre 'dinner' appeared less than generous" (NCH, 19 January 1929, 127). While these establishments were often associated with hotels and targeted visitors, third-class establishments, jokingly referred to as pectopah by Western visitors to Harbin, were popular with the local Russian customers. In such places, "the temptation is to overeat", because "the food is good and the cooking remarkably good", and the diners stuff themselves "to a point of serious discomfort" (NCH, 19 January 1929, 128). In restaurants of all ranks, the starters, zakouskas, were the most enticing and abundant part. Westerners visiting Harbin remarked that eating out was the best thing the city had to offer, since "so much else that is widely advertised turns out to be pathetically sordid" or "chiefly make-up and make-shift" (NCH, 19 January 1929, 128).

If one genre from the Russian culinary palette stood out from the rest, it was Caucasian cuisine, originating in the mountainous region of Caucasus in the south-western corner of Russia. A Western visitor to a Caucasian restaurant in Harbin described its owners as having a look between "a Russian, a Turk and a pirate" (China Weekly Review, hereafter CWR, 9 November 1929, 380). For Russians, the Caucasian cuisine, and specifically that from the region of Georgia, was familiarly exotic, "not alien either to our ear or to our taste" (Nakhimovsky 2006, 72). It was typically represented by "crusty Georgian 
bread and sharp cheese, renowned Georgian wines, dishes whose names sound like music: satsivi, chakokhbili, khachapuri, lobio, suluguni" (Metreveli and Bar-Sliva 2001, 5). Georgian dining appealed to the Russian palate with a range of highly developed tastes: roasted, grilled and stewed meats; complex seasonings composed of coriander, saffron and other rare spices; subtle sauces combining sweet and savoury flavours with a taste of pomegranates, walnuts and tangy plums (Scott 2012,835). The prime offering by Caucasian restaurants based in China and elsewhere was shashlyk - grilled meat on a skewer - which first appeared on Russian menus in the middle of the 19th century, following the Russian expansion into the mountainous region. The Georgian meat stew (chakhokhbili) was in wide demand as well.

Sophisticated Georgian food and drink were believed to be best enjoyed in tandem with elaborate toasting rituals, and restaurants in China made sure to replicate the spirit of the Caucasian dinner as well as its fare. To make the marketing easy, Caucasian restaurants in Harbin and Shanghai adopted the simple name Kavkaz, Russian for the Caucasus. The cuisine was popular with the public, and at any given time there was more than one Kavkaz in Shanghai. One of the earliest Caucasian restaurant in Shanghai was Alla Verdy (the name means "passing the toast to the next person"), run by the Armenian expatriate Enoch Sarkissian and the Georgian Colonel Joseph Nozadze. In 1926 the restaurant featured in an essay by M. Scherbakoff as "a small unkempt building", where the guests were greeted by "the wasp-waisted host in a traditional Caucasian long coat", who stepped out from "the smoke-filled entrance" (Shcherbakov 2011, 164). The interior, the food, the drinks and the service were underwhelming, but nostalgic:

In the best private room there was nothing there except a table, a wide bench covered with a thick Bukhara carpet hanging from the wall, and an old broken piano, but the memory of the maze of filthy streets leading to the restaurant made this simple arrangement seem cozy. Marcel ordered: "Bring Russian zakouski and champagne." Lola added: "And send your musician here." This place, despite its shabbiness, somehow resembled old Petersburg - not its solemn palaces and embankments, but its small subterranean grill-bars. [...] There was a knock on the door, and the pianist walked in. He was unshaven and looked consumptive. He exclaimed: "Bonjour, s'il vous plait!" and bowed.

(Shcherbakov 2011, 164-6)

There was no hard line between Slavic and Caucasian restaurants; both kinds strove to make themselves familiar to Shanghai's cosmopolitan audiences by advertising dinners, tiffins, zakouski, Russian atmosphere and fine entertainment. The lack of authenticity in interior design and food was, no doubt, a consequence of the fact that only the most seasoned restaurateurs boasted 
trade experience outside of China, whereas most culinary careers developed in the Russian Far East or China's north. A memoir by an ethnic Harbin-born Georgian who spent his youth in Shanghai described a mid-1930s Georgian restaurant on Avenue Joffre as a comfortable place with walls covered with murals depicting Caucasus mountains and streams "as painters that have never seen it like to imagine it" (Khaindrava 1989, 69).

In the early 1930s the English-language press wrote extensively about the Russian "invasion" of Shanghai, following the relocation of the Russian population from Shanghai's north district to the French Concession and the quick transformation of its urban landscape. The "galaxy of gardens" (restaurants with open-air seating), "garish restaurants" and "sweet shops" made Avenue Joffre "informal, tawdry, yet picturesque, as a ship in full dress" (TCP, 3 July 1931, 11). One estimate claimed 61 Russian-owned restaurants in the French Concession in 1931, and 28 grocery stores, among other businesses (CWR, 21 November 1931, 438). By another calculation from the same year, there were more than 150 Western eateries in the whole city, and a large part of them were Russian (Farrer 2015, 82). The press observed that "the Russian influence in Shanghai is expressed greatly in the splendid restaurants where everything from salty zakuskas to soft thick ice cream abounds" (TCP, 8 November 1931, 13). Given the wealth of choice, diners embarked on a search for authenticity, struggling to find the "truly Russian" places, where one needed an interpreter to place an order, where "the diners, the food, the menu, the waitresses, the music, everything was Russian" (CWR, 27 December 1931, 133) The food offerings in those "authentic" restaurants were very similar to those more tourist-oriented places and included beef stroganoff, chicken cutlet à la Kiev, mutton skewers (shashlyk), homemade ice cream and Warsaw-style coffee. The "slightly bewildered [...] Englishmen, Americans, Frenchmen and Germans you see every night at local Russian restaurants" were reportedly trying hard to retain their dignity before the customary deluge of zakouskas (TCP, 8 November 1931, 13). The Russian food craze was contagious: in 1930 zakouska and borscht were included in the menus of American clubs in Shanghai (CWR, 27 December 1931, 133).

The choice of food and drink in restaurants was prone to seasonal change. In summer, the producers of ice, soda drinks and ice cream made the most of their sales through cabarets and soda fountains. The customers of the restaurants, reluctant to dance in the subtropical heat, eased off taxi dancing, but the loss in dance tickets for the establishment was repaid more than twofold by the extra consumption of soft drinks that sold with a 500\% markup (Segodnia, 5 July 1941, 20). In winter the brothers Tkachenko promoted homemade sweets, holiday candy and halva from their confectionary across the street from the restaurant. The coming of Easter called for production of chocolate bunnies and eggs, a nod to Western tradition, as well as traditional Russian pastry (kulich) and soft cheese pudding (paskha) (Rossica 1941,37). Even after the Tkachenkos lost control of their restaurant they retained the ownership 
of the bakery, and by the end of the 1930s it grew to four branch stores. Maintaining a separate brand identity, the brothers emphasized the legacy of their bread, "famous in Russia's Far East and Siberia since 1907" (Parus, 25 February 1937, 15) and marketed their stuffed pastry (piroshky) as "the best in town".

In the shadow of the larger and better-appointed venues that received multilingual press coverage were scores of small-scale ad hoc Russian eateries that focused their services on their own community. If they ever appeared in print, it was in the local news - as backdrops to some poverty-related crime - or in small print ads in the Russian-language classifieds: "Try our home-cooked meals. We accept monthly diners. Dinners: 165, Suppers: 180. Everything is prepared by the owner Valentine. 1706 Avenue Joffre" (Shanghai Zaria, 2 November 1941). Among these places were canteens that offered simple meals like "boiled sausages with cabbage on the side, a glass of tea and a wedge of apple strudel" for a total of 40 cents (Khaindrava 1989, 121) or sold soup by tureens (Titov 2014). Boarding houses, where the majority of the Russians lived, offered dinners to lodgers or any visitors. Lastly, there were informal case-by-case arrangements, such as ordering home-cooked meals by telephone. A number of canteens were sponsored by benevolent societies and provided cheap meals for impoverished members of the community.

\section{European cafés as a clandestine engine of modernity}

Urban restaurant scenes are a long-established phenomenon in China. They can be traced back to the Song Dynasty (960-1279), when the concentration of merchants, craftsmen and intellectuals in the cities "stimulated the development of urban eateries functionally similar to modern restaurants, characterized by menus, waiters, entertainers and sophisticated ways of attracting and serving a revolving clientele" (Farrer 2015, 115). Urban dining at the treaty port of Shanghai was influenced by the adoption of French cuisine, as Parisian-style restaurants went global in the 19th century, bringing French high cuisine to the growing urban bourgeoisie. Culinary Occidentalism was especially important to Shanghai residents' claims as to their city's rising cultural standing (Farrer 2015, 115). "The association of Shanghai with Western food culture cemented Shanghai's status as the vanguard of China's engagement with foreign culture" (Swislocki 2008, 125). Over time, a hybrid menu of Western cuisine (xican) emerged that combined French, German, British, Russian, Italian, American and Anglo-Indian flavours (Farrer 2015, 116). Cosmopolitanism reached its apogee towards the end of the 1940s, when a newly opening Russian restaurant would advertise sukiyaki, Russian dishes, Georgian shashlyk and Indian curry (CWR, 18 June 1949, 46). On the culinary stage of Shanghai, the Russian diaspora's foodways left a lasting imprint, as items like "Russian soup" (a cabbage, beef and tomato soup inspired by borscht) found their way into even the ordinary household menus of the Shanghainese. 
Dining at least occasionally in Western restaurants or cafés was a regular feature of Shanghai life as of the 1920s, even for the middle classes. Chinese customers of Russian eateries took into consideration a factor that played a less important role for the wealthier Western clients: the prices. Russian eateries were considerably cheaper than other Western restaurants. In a letter from the poet and writer Zhu Ziqing to the prominent writer and publisher Ye Shengtao, Zhu nostalgically recalled a meal in a popular Russian restaurant in 1930; in Zhu's opinion, the restaurant's popularity was as much due to its affordability as to the fact that the dishes were cooked in oil, not butter, which suited the Chinese taste better, and they were easy to share (Liao 2014).

If Russian restaurants represented the culinary practices of the Russian Empire augmented by contact with the Far East, Russian-run cafés occupied a more exotic culinary and cultural territory, representing the European style. Looking at the open-air cafés on Avenue Joffre, with their tapestry awnings, quaint windows and blond waitresses, even the discerning Western journalists were willing to half-close their eyes and pretend they were in Paris, so convincingly European were Russian-run garden cafés: "All the charm of good living, of material and wholesome pleasure belong[s] to the thoroughly European garden cafes along the street" (TCP, 3 July 1931,11). The largest segment of the population - the Chinese - responded to this phenomenon and made it their entry point into the world of Western modernity.

The cultural mimicry of the Russian café owners was rooted in their heritage. France has been a powerful cultural attraction for the Russian upper classes for centuries (Hassell 1991, 2). Young Frenchwomen had brought up generations of aristocratic children, passing down, among other things, the habit of speaking French at home. The French Riviera since the middle of the 19th century had been a vacation spot favoured by wealthy Russians, including the royal family. Shanghai Russians generally looked up to their brethren in Paris, picking up the cultural dynamics by reading diaspora newspapers that represented the Parisian café as the typical meeting place where one could drink spirits or coffee, have a meal or not and enjoy the company of one's friends in a relaxed atmosphere (Hassell 1991, 13). Russians adopted not only the time-proven French phenomena, but also the latest fashions of the time. At the same time as Josephine Baker was exciting Paris with her exotic dance numbers, the Shanghai-based operetta singer and dancer Maria Danilevich was imitating her in a New Year revue presented at the Kavkaz restaurant. Her show was widely advertised in the English-language press and promised to "go down in history as one of the best that Shanghai pleasure-seekers have seen in a long time" (TCP, 12 January $1930,3)$.

The coffee house fashion emerged in the early 1920s, and the first cafés to leave their mark had Chinese and Japanese owners and were frequently affiliated with bookstores. Like the English-language press, Chinese newspapers remarked on the emergence of a new café zone on Avenue Joffre (Pang 2006, 26). While the cafés in the northern area of Shanghai had a cloistered, indoor 
atmosphere, the Russian "French" cafés of the French Concession modelled themselves on the open-air street-side Parisian cafés (Pang 2006,26).Though at first the Chinese customers did not make a sharp distinction between Western cultures, favouring German and American-run enterprises as much as Russian, their experiences of the latter left a deeper mark, and indeed found expression in the modern prose of the time, as the Russian cafe wove its way into the documentary prose and fiction of the day.

The 1930s were the hotbed of the Chinese modern literary tradition. The Shanghai literati admitted to getting accustomed to Western ways during their endless hours spent in Shanghai's European-style cafés. The influence of the café culture on Chinese modernization was undeniable: along with large Chinese bookstores, smaller innovations such as the cafe culture of the French Concession enabled Chinese literary figures to inject an idea of European cosmopolitanism into their lives even when they had never set foot outside China (Mitter 2004, 52). The essayist Zhang Ruogu was caught up in the literary world's "coffee house craze" in the 1920s, spending time at his favoured haunts, such as Constantine's, that served authentic Arabian coffee. He wrote in 1929, "I spent practically all my leisure time in the cafes on Avenue Joffre [...] Come late afternoon, all of us would gather [...] and as we drank the strong and fragrant coffee to enhance our fun, we would gently talk our hearts out" (Mitter 2004, 53). His favourite haunt was the Balkan Milk Store, which offered coffee at cheaper prices than the more upmarket Café Federal (German-owned) and Marcel (French-owned); there he and friends could spend long hours undisturbed by waiters. Zhang also favoured the Russian café Little Man, across the street from the Cathay Theatre, "where the décor is splendid and the waitresses young and pretty" (Lee 1999, 99). Zhang considered the coffee house one of the crucial symbols of modernity, together with the cinema and the automobile.

The owners of the long-lived Café Renaissance fancied themselves as patrons of arts, so they designated a special room, called Bohemia, to the meetings of Shanghai literati and artists. Zhang Rougu devoted one of his essays to the Renaissance, in which he "constructs a scenario involving three well-dressed young men, three musketeers of the metropolis", who bring with them a fashionable modern girl in an automobile (Lee 1999, 22). Literary Shanghai responded to the coffee house craze with essays, translations and plays, such as Tian Han's One Night in a Café. All this Occidental exotica "naturally converged on a bohemian self-image" (Lee 1999, 100), which infused characters from the opera La Boheme with the nationalist fervour cultivated by the young writers.

By the 1930s Shanghai had become the fifth largest city in the world and an international legend, often referred to as the Paris of the East. The name Shanghai was nearly synonymous in China with modernity. As a treaty port, the city was also the site of China's confrontation with globalism and cosmopolitanism. The co-residence of foreigners and Shanghainese had far-reaching influences on each other's daily lives, resulting in a hybrid lifestyle (Zhao and Belk 2008). "Electric fans, 1930-model Citroëns, radios, foreign-style mansions, 
Browning guns, cigars, perfume, high-heeled shoes, beauty parlours, 1930 Parisian summer dresses, Japanese and Swedish watches, as well as all forms of entertainment, such as dancing, bordellos, greyhound racing, Turkish baths, and films", were part of the urban consumption-scape (Lee 1999, 4-5). Even though few Chinese in Shanghai could afford to participate fully in this consumer culture, almost everyone was influenced in some way by the flood of new goods, food and entertainment, and what happened in Shanghai gradually spread to other parts of China (Johnson et al. 1985).

\section{Conclusion}

By the late 1920s Russian diasporas around the world were well established, and the separation from the motherland was understood to be permanent. In Shanghai, Russians were lodged in the middle of a thriving bourgeois economy of the semi-colonial free port. Here the refugees essentially pursued an economic trajectory that had been interrupted in the Russian motherland by the October Revolution; they adapted to a self-governed society, participated in and transformed the economic life of the city and established a thriving middle class. Where their economy connected to hospitality was the most visible and best-documented part, as reflected in memoirs, interviews, advertising and newspaper reports, perfectly illustrating the economic pattern of capitalist development outside of the constraints of the new Soviet government.

Fugitive, but influential elements of cultural exchange between Russians, Chinese and the European citizens in 1930s Shanghai have been brought to light from examination of the Russian diaspora in its early material development - specifically, the activities of the food workers and restaurateurs and the public reaction to the Russian hospitality business in the treaty port. We have begun to assess the role that Russians played in the socioeconomic development of Shanghai, demonstrating how Russian culinary culture became a persuasive pageant and a laboratory of behaviour, for better or worse - a model of Western modernity in China. The culinary residue of the Russian diaspora continues to inform urban experience in Shanghai, from the integration of Slavic recipes into the traditional Shanghai cuisine to the continued existence of brands and venues that go back to the heyday of Shanghai's "Little Russia".

\section{References}

Bulgakova, O. (2005) “The 'Russian vogue' in Europe and Hollywood: The transformation of Russian stereotypes through the 1920s", The Russian Review 64(2): 211-35.

China Press (1925-38).

China Weekly Review (1923-50).

Directory \& Chronicle for China, Japan, Corea, Indo-China, Straits Settlements, Malay States, Siam, Netherlands India, Borneo, the Philippines ... (1905), Hong Kong: Hong Kong Daily Press. 
Directory \& Chronicle for China, Japan, Corea, Indo-China, Straits Settlements, Malay States, Siam, Netherlands India, Borneo, the Philippines ... (1920), Hong Kong: Hong Kong Daily Press.

Eisfelder, H. (2004) Chinese Exile: My Years in Shanghai and Nanking, Melbourne:Ayotaynu Foundation.

Farrer, J. (2015) "Michelin stars over China: The place of France in Shanghai's culinary contact zones", Proceedings of the 2015 International Conference on Chinese Food Culture, 113-38, accessed at www.fcdc.org.tw:8999/english/publish/publish_detail. aspx?sn $=468 x k$ kind $=1$

Fedoulenko,V.V. and Raymond, B. (1978) Valentine Vassilievich Fedoulenko, Russian Emigré Life in Shanghai, Berkeley: University of California Press.

Gilbert, R. (1929) "Harbin and its inhabitants", The North-China Herald and Supreme Court \& Consular Gazette, 19 January.

Hassell, J.E. (1991) "Russian Refugees in France and the United States between the World Wars", Transactions of the American Philosophical Society 81(7): 1-96.

Johnson, D. et al. (eds) (1985) Popular Culture in Late Imperial China, Berkeley: University of California Press.

Khaindrava, L. (1989) Ocharovannaia dal, Moscow: Sovpisatel.

Khisamutdinov, A.A. (2010) Russians in China: A Historical Review, Shanghai: Russky Club.

Knyazeva, K. (2017) "High and low: the material culture of the Russian diaspora in Shanghai, 1920s-1950s", Global Histories 3(2): 21-42.

Lee, L. (1999) Shanghai Modern: The Flowering of a New Urban Culture in China, 19301945, Cambridge, MA: Harvard University Press.

Liao, F. (2014) "Foreign flavors", Global Times (27 February 2014), accessed at www. globaltimes.cn/content/845106.shtml.

Mack, G.R. and Surina A. (2005) Food Culture in Russia and Central Asia, London: Greenwood.

Metreveli,V.V. and Bar-Sliva, I.M. (2001) Gruzinskaia kukhnia, Moscow: Eksmo Press.

Mintz, S. (2008) "Food and diaspora", Food, Culture \& Society, 11(4): 511-23.

Mitter, R. (2004) A Bitter Revolution: China's Struggle with the Modern World, Oxford: Oxford University Press.

Muratov, P. (1934) “Toward the sun”, Vozrozhdenie: La Renaissance 9(3181): 3.

Nakhimovsky, A. (2006) "You are what they ate: Russian Jews reclaim their foodways", Shofar: An Interdisciplinary Journal of Jewish Studies 25(1): 63-77.

North-China Herald and Supreme Court \& Consular Gazette (1870-1941).

Pang, L. (2006) "The collective subjectivity of Chinese intellectuals and their cafe culture in republican Shanghai”, Inter-Asia Cultural Studies 7(1): 24-42.

Parus (1931-9).

Ristaino, M. (2003) Port of Last Resort: Diaspora Communities of Shanghai, Stanford, CA: Stanford University Press.

Rossica (1930-41).

Scott, E.R. (2012) "Edible ethnicity: How Georgian cuisine conquered the Soviet table”, Kritika: Explorations in Russian and Eurasian History 13(4): 831-58.

Segodnia (1941-3).

Shanghai Gazette (1919-21). 
Shanghai Times (1914-21).

Shanghai Zaria (1925-40).

Shanghai Zhinan (1918).

Sharonova, V.G. (2015), Istoriia russkoi emigratsii v vostochnom Kitae v pervoi polovine XX veka, Saint Petersburg: Universitetskaya Kniga.

Scherbakoff, M. (2011) Oddissei bez Itaki,Vladivostok: Rubezh.

Skillen, D. (2014), “The Astoria Confectionary and Tearoom”, Historic Shanghai, accessed at www.historic-shanghai.com/the-astoria-confectionary-tea-room-a-memoir/ .

Swislocki, M. (2008) Culinary Nostalgia: Regional Food Culture and the Urban Experience in Shanghai, Stanford, CA: Stanford University Press.

Titov, A. (2014) Zdravstvui, Shanghai, accessed at www.rusconshanghai.org.cn/useful/ shanghai/titov-memory.

Wang, Z. (1993) Shanghai e qiao shi, Shanghai: Sanlian Shudian.

Wasserstrom, J.N. (2009) Global Shanghai, 1850-2010: A History in Fragments, London and New York: Routledge.

Zhao, X. and Belk, R.W. (2008) “Advertising consumer culture in 1930s Shanghai: globalization and localization in Yuefenpai”, Journal of Advertising 37(2): 45-56.

Zhiganov,V.D. (1936) Russkie v Shanhae, Shanghai: Slovo. 
Conclusion 
$\because$ Taylor \& Francis Taylor \& Francis Group

http://taylorandfrancis.com 


\title{
Careful with heritage
}

\author{
Ilaria Porciani and Massimo Montanari
}

\section{Observe, describe, don't freeze}

At the beginning of the long 19th century, heritage belonged essentially to the cultural sphere. It was no different for food heritage. Intellectuals, historians and folklorists made large use of it with the aim of "awakening" the national consciousness - as the phrase went. They used it as part of the nation-state discourse (Berger and Conrad 2014). Such rhetoric powerfully conveyed a strong feeling of inclusion within the nation, well described as wir Gefühl (the "us" feeling) by Norbert Elias. But it also implied othering and the exclusion of "aliens".

Food and taste, more than other elements of the imagined community of the nation (Anderson 1983), convey the feeling of "home", embody sensorial memories imbued with nostalgia and nurture the feeling of belonging together. Thanks to its nature, rooted in culture as much as in the zoe-mere everyday life - food has proved extremely successful in linking the idea of the Kulturnation to its daily domestic experience, thus indirectly supporting the interpretation of the nation as a family, sometimes even in the ethnic sense.

As Paolo Capuzzo suggests here (Chapter 4), since the beginning of industrialization - which obviously took place at different times in different countries - and even more so in the age of globalization, food heritage has rapidly shifted towards commodity: it has turned into commodity heritage - artefacts modified in order to enter the global market (Grasseni 2005). More: they have become "a political artefact, on its way to becoming a tourist artefact" (Mintz 2003, 26).

Both UNESCO's nominations to world intangible heritage and the EU's quality place-based labelling, created in their different ways as means of protecting culinary diversity and authenticity, have generated risks, as Laura Di Fiore (Chapter 2) and Fabio Parasecoli (Chapter 3) point out in this book. Thus, cuisine heritage has turned into a truly contested issue which has even fuelled food wars, especially where ethnic, national or political conflicts have existed, as discussed in the introduction.

Gisela Welz reflects on the case of two products. Lokoumi Geroskipou, linked with the firm Aphrodite's Delight based in the Greek part of 
Cyprus, was in 2007 entered in the European Union Registry of Protected Geographical Indications. Thus, this sweet became strictly connected to Cyprus. Welz also focuses on halloumi cheese, which was not entered in the protected denomination list, but was strongly promoted once again by the Republic of Cyprus shortly after it joined the European Union (Welz 2013). The German anthropologist highlights the contested origins behind those two stories, the first a successful and the second an unsuccessful one, as well as the bitter criticisms that they aroused. In fact, the same candy under the name of lokum or Turkish delight is not only produced in the Republic of Cyprus, but also in the still internationally unrecognized Turkish part of the island, and of course in Turkey itself, but also Armenia and Iran. Moreover, this delight, in different versions, was manufactured and widely consumed throughout the Ottoman Empire.

The case of halloumi is similar and yet different, since it was produced not only in various places, originally by extremely small groups of women, and was made out of cow, sheep or goat milk. The cheese, though bearing the same name, tastes different according to the kind of milk used or the season or the herbs eaten by the animals whose milk is used. In both cases, however, application for a quality label resulted in a remarkable hardening of the products. Standardization prevailed over variety, singleness over plurality of tastes, maintenance of exactly the same qualities over flexibility. In short, the immobility of a supposedly authentic place of production prevailed over changes in time. What got lost was the living wealth of hybridization and exchange embodied in these foods, as in almost every cuisine, as Massimo Montanari (Chapter 7), Özge Samanc1 (Chapter 9) and Catherine Horel (Chapter 8) have highlighted here, referring respectively to Europe of the Middle Ages and the Ottoman and Habsburg Empires.

Inventories and forms of protection are a useful way of controlling the quality of food and avoiding confusion between industrial dishes prepared with artificial flavours or colours and food properly prepared with good ingredients. However, labelling and bureaucracy tend to freeze one set definition and recipe. Ignoring or at least downplaying the plurality of its various versions and the multiplicity of places and larger or smaller communities which contributed to creating such a dish, they end up in favour of strict, homogeneous, codified canons. Instead of choosing this way, one should surely set gastronationalism aside and perhaps follow the new path of ecogastronomy (Goodman, Dupuis and Goodman 2012).

\section{The chefs' way}

Food nationalism seems to grow stronger as a result of the European Union's recent difficulties. As an extreme example one could quote the words of UK Environment Secretary Michael Gove who, in late 2017, stigmatized an 
"unpatriotic attitude towards cheese" in the face of concerns about tariffs on cheese imported to the United Kingdom after Brexit, as if British citizens should consume British cheese and eschew foreign cheese as a matter of patriotism. ${ }^{1}$ It is therefore important to reflect once more on the concepts of authenticity and of food heritage in their connections with nationalism, and to suggest a more flexible idea of heritage which can reflect the food differences and the nuances within Europe.

In a short paper written in 1986 when he was a fellow of the Palo Alto Center for Advanced Study in Behavioral Sciences and meanwhile acting as a reviewer of the restaurant scene in the San Francisco area, Arjun Appadurai discussed the authority of gastronomic standards. A well-known postcolonial intellectual as well as the author of a major early contribution, Gastropolitics in Hindu South Asia (Appadurai 1986), he asked questions about immanent norms and authorities. Among other agencies, he quoted restaurants and professional cooks:

Authenticity as a criterion seems always to emerge just after its subject matter has been significantly transformed. How is one to generate stable criteria of authenticity for traditions that are always changing? All cuisines have a history: tastes shift, regional distinctions go in and out of focus, new techniques and technologies appear. New foods come in and go out of vogue in all complex culinary traditions. The idea of authenticity seems to imply a timeless perspective on profoundly historical processes. Thus, the transhistorical ring of authority with which the word authenticity is sometimes used in the evaluation of foreign cuisines is spurious.

(Appadurai 1986: 25)

Restaurants and cooks are present in the introduction as well as in the chapters authored by Katya Knyazeva (Chapter 11), Catherine Horel (Chapter 8) and Jean-Pierre Williot (Chapter 10). Now is perhaps the moment to briefly focus on chefs, and point out the role they are having, and that some of them already had: to be sure, a very important one when it comes to defining, criticizing and creating standards.

Ironically, on the global scene, it is some of the most important Michelinstarred chefs who have voiced the need for closer attention to variety, terroir and respect for sustainability. In spite of the fact that they are de facto producing food for a tiny community of very well-off consumers, these worldwide stars for a global public put forward issues previously claimed by slow food or countercultures, as Marica Tolomelli points out in this volume (Chapter 5).

If Alice Waters was one of the first to call for a profound trend change in cuisine, most creative innovators in the field of gastronomy now focus their sights on the local. While hundreds of thousands of pigs on large industrial farms recently bought by the Chinese are fed with soy produced in intensive monocultures in South America and their meat is sent to other 
continents for the tables of mass consumers, the chefs look for small farms and ancient breeds of cattle, praise sustainability and claim to serve their clients dishes made of the entire animal, including the supposedly "poorer parts" like head or tail. It is the great chefs who look at the traditional species of fruit trees and plants that were about to disappear because their yield was considered too low. Corrado Assenza, who took over the small family enterprise of sweets and pastries, a true laboratorio artigiano (a true artisan's workshop) in Noto, Sicily, has chosen to utilize only the ancient and local species of almonds. By using them in his preparations, he made them interesting for farmers, who were at this point sure to find a market for their onceneglected product. Thus he saved the Sicilian almonds, now named after the city of Avola, from disappearing, and had a direct impact on a landscape which is per se heritage. ${ }^{2}$

Thai chef Bo Sangrisava revolted against a uniform fake Thai food being imposed on the global market. She wanted to show Thai people that they could be proud of their food and rise above the global trivialization of their cuisine. She started looking for special original ingredients at risk of disappearing. Likewise, Peruvian chef Virgilio Martínez declared that he wanted to represent the entire country in all its landscapes and altitudes, and has been searching for new ingredients which he presents together with stones, rocks, musk from the Andes or the Peruvian seaside: the essential elements of the bio- and landscape. The same goes for chef René Redzepi, of Balkan origin but now active in Copenhagen as the owner and creative mind behind Noma, four times voted the best restaurant in the world. He also wants to propose the "real Danish landscape" with its culture, game and forests.

This interest in the landscape and the soil recalls early 19th-century nationalism and its focus on the same features: the Boden - the soil - was one of the two elements in the successful German nationalist expression Blut und Boden (blood and soil) which summed up the German Volk for so many years in common parlance as well as in museums featuring the nation and its landscape. Now, in a quite different context, and speaking to a different public, these chefs search for the terroir, the soil itself, only they reverse the significance: they no longer connect it with the Volk but with a human landscape to protect and cherish, and with the crucial issue of sustainability.

Musa Dağdeviren, creator of the quarterly Yemek ve Kültür (Food and Culture) as well as owner and soul of the restaurant Ciya in Istanbul, who also figures in the same Netflix series Chef's Table as the aforementioned chefs, wisely declared: "When you define food in ethnic terms, it sets communities against each other and can create a serious alienation and extinction of our food culture". Dağdeviren has carefully avoided isolating national elements, highlighting shared histories and mutual influences instead. ${ }^{3}$

Food heritage can be a terrible hardener of borders. However, if the discourse is properly deconstructed, and all its coexisting movements, grafting, exchanges and negotiations are laid bare, it can also make those borders more porous and tell shared histories instead of divisive ones. 


\section{Respecting differences: the Artusi model}

Let us now go back to the 19th century in order to reread and reinterpret the lesson of a great gastronome in post-unification Italy: Pellegrino Artusi.

This classic example from the history of Italian cuisine suggests it is possible to keep track of and indirectly safeguard a flexible gastronomic heritage based more on a bottom-up movement than on a top-down regulation. Artusi (Montanari $2012,8)$ was the first to make an inventory of local cuisines and create a national language for Italian gastronomy. He composed his work from recipes he came across or that reached him from many parts of the country. It was largely women who wrote to him to correct or complete his recipe book and suggest new dishes. In this collective way, albeit filtered by Artusi's commanding personality, the first recipe book of united Italy was compiled: La scienza in cucina e l'arte di mangiar bene (Science in the Kitchen and the Art of Eating Well) (1891). It was to be updated and added to repeatedly, running to 15 editions by 1911.

It may not be the only example of a bottom-up syncretically compiled national recipe book, or of a common feeling of belonging being created upon a varied cuisine that became a shared possession thanks to a recipe book. In this Artusi's method might perhaps be compared to Appadurai's study of the Indian situation (Appadurai 1986).

When it comes to what we might call the European culinary heritage, our attitude must be critical and prudent. We are well aware that UNESCO cares about an intangible heritage which should be not only traditional, but also "contemporary and living at the same time". "UNESCO pays attention to "living practices", and has seen the risk that "freezing practices" may prove "aberrant" (Bortolotto 2013, 65). However, every process of construction of a canon and a list may contain a risk of "freezing". The solution proposed by Artusi went in the right direction: faced with a host of local traditions, he chose not to codify the recipes (that is, to find out the "right" way to perform them) or to propose them as "national" and valid for everyone, but simply to recount the recipes he found interesting. He put them in a network and shared the knowhow, but respected the differences. We feel that such an approach - typical of Pellegrino Artusi but also more generally of Italian gastronomic culture - might serve as a model for displaying the European food heritage. The line we suggest in concluding this book is thus to refrain from encasing a gastronomic heritage in rules: in other words, not to codify or museify it.

\section{Focusing on time and not on space}

It also appears important not to enclose that heritage within predefined territorial borders stressing the spatial dimension so beloved of our times. Witnessing the predominantly geographic sense we nowadays attach to the notion of origins tends to immobilize knowledge inside artificial boundaries. It would surely be more important to focus on the time dimension, which keeps things alive and on the move. 
In charting and respecting differences as an intrinsic value, taking a leaf out of Artusi's book, our acclaim goes not to an unchanging reality but to the value of a heritage that is not laid down once and for all but is in constant evolution thanks to the crossed influences that history provides.

The crucial, and politically important, issue is what line to take on "tradition". All traditions are no doubt subject to change, so had we not better leave them free to unfold creatively, instead of fossilizing them or letting them slide into an at times unstoppable decline (Nas 2002, 140)?

As for the specific angle that interests us here - heritage - we may draw some advice from the example of a practice that was in danger of extinction: Javanese shadow theatre. In the 1980s it had touched rock bottom but was saved, not because it became an object for protection, but because it managed to transform itself. It transcended codified tradition by resorting to new musical instruments and breaking rules that had become over-rigid and dated. A typical place-related art form was saved by transforming itself quite without inventing a top-down tradition. It would pay us to observe and learn and not define rigid standards from above.

Inventories created from below, being less rigid and prescriptive, may enhance the perception of food as an immaterial heritage that is decisive for collective identity, but also syncretistic, elastic, mobile and open to exchange, happenstance and alteration. Perhaps this road is better than the political way of certifying (Clough 2015), which anchors the gastronomic heritage to fixed identities, "cultures" dangerously bound up with ethnic belonging which itself is seen as static and not - as is the case - the upshot of constantly changing events and stories. The doubt is whether heritage conservation in a museum framework may actually be breeding new intolerance and new nationalism, perhaps under a different name. That is why we think it so important to steer all discussion of origins, traditions and heritage onto a time and not space dimension, history not geography.

\section{Notes}

1 www.bbc.com/news/uk-politics-42427812 accessed 28 February 2019.

2 Ironically, the consortium of the Avola almonds is awaiting the IGP from Brussels. See www.Consorziomandorlaavola.it accessed 28 February 2019.

3 www.eater.com/2018/9/28/17888274/chefs-table-musa-dagdeviren-season-5episode-2 accessed 28 February 2019.

4 https://ich.unesco.org/en/what-is-intangible-heritage-00003 accessed 28 February 2019.

\section{References}

Anderson, B. (1983) Imagined Communities: Reflections on the Origin and Spread of Nationalism, New York: Verso. 
Appadurai, A. (1986) “On culinary authenticity”, Anthropology Today 2(4): 25.

Bortolotto, C. (2013) "L'Unesco comme arène de traduction. La fabrique globale du patrimoine immatériel", Gradhiva 18: 52-71.

Berger, S. and Conrad, C. (2014) The Past as History: National Identity and Historical Consciousness in Modern Europe, Basingstoke: Palgrave Macmillan.

Clough, E. (2015) “The politics of food labelling and certification", in R. G. Herring (ed.), The Oxford Handbook of Food, Politics and Society, Oxford: Oxford University Press, 615-43.

Goodman, D., Dupuis, E.M. and Goodman, K. (2012) Alternative Food Networks. Knowledge, Practice and Politics, Abingdon: Routledge.

Grasseni C. (2005) "Slow food, fast genes: Timescapes of authenticity and innovation in the anthropology of food", Cambridge Anthropology 25(2): 79-94.

Mintz, S. (2003) "Eating communities. The mixed appeal of sodality", in T. Döring, M. Heide and S. Mühlstein (eds), Eating Culture: The Poetics and Politics of Food, Heidelberg: Winter, 19-34.

Montanari, M. (2012) "Le ragioni di un successo", in G. Frosini and M. Montanari (eds), Il Secolo artusiano. Atti del convegno Firenze-Forlimpopoli 30 marzo-2 aprile 2011, Florence: Accademia della Crusca, 7-16.

Nas, P.J.M. (2002) "Masterpieces of oral and intangible culture. Reflections on the UNESCO World Heritage List", Current Anthropology 43(1): 139-48.

Welz, G. (2013) "Contested origins", Food, Culture \& Society: An International Journal of Multidisciplinary Research 16(2): 265-79. 


\section{Index}

Note: Pages in italics indicate figures on the corresponding pages.

Agnetti,V. 70-1

agrobiodiversity 61-2

Akkor, Ö. 157

alafranga 164

Americanization 12

American Woman's Home, The 16

Anatolia 156, 158, 160-2, 165, 167

Andreeva, K. A. 17

Andrew, G. 93, 95

anthropologists 7, 11, 151, 171

antisemitism 146

anti-systemic protest 90

Appadurai, A. 207

Arab influence on European cuisine $127-8$

aristocracy $23,71,192$

Armenia 23, 43, 71, 143, 155, 158, 159, 160, 167, 192, 197

Armenian population 143

Arnold-de Simine, S. 108, 111, 117-18

Art of Cookery Made Plain and Easy 20

Art of the Neapolitan Pizzaiuolo 39, $42,45,62$

Art of Turkish Cuisine 161

Artusi, P. 12, 67, 68, 209, 210

Assenza, C. 208

Auschwitz Museum and Memorial 115, 116-18, 117

Austrian Mehlspeise 148

Austro-Hungarian cooking 151-2; chefs and cookbooks in 149-51; cities and marketplaces of 142-4; hybridism and transformation in multinational Habsburg Empire 138-42, 141; inventing the tradition of Viennese cuisine in 147-9; mobility and 144-7; pastry tradition 149; see also European cuisine

authentic cuisine 88-90

authorized heritage discourse 5

bagna càuda 74

Banal Nationalism 7

barbacoa 18

Barbarians 125-6, 129; culture 126; "Roman-Barbarian" dietetic pattern 126

barbecuing 18

Barilla company 78-9

Barth, H. 67

Barthes, R. 7

Bazán, E. P. 18, 67

Beamish Open-Air Museum 107-12

Beecher, C. 16

beer 23, 67, 130, 132, 133, 140, 145, 179, 184; beer-drinking countries 128 ; Belgium's culture 41; consumption 130; culture 126, 127; Czech 145; Dreher's beer 140-1; Germany 90; Italy 133

Bel Paese 76

Be Merry Around Our Table 158

Bessière, J. 7

Billig, M. 7

Bohemia (Karlsbad/Karlovy Vary, Marienbad/Mariá nské Lázně, Franzensbad/Frantyškovy Lázně) 9, 139,146

borders 7, 19, 22, 23, 43, 74, 101, 140, 190, 208, 209

Bortolotto, C. 44

bourgeoisie 66, 199

Bové, R. 12 
Boym, S. 108, 119

Bozoğlu, G. 6

bread: baking 86 ; breadcrumbs 127 ;

brothers Tkachenko 199; brown 132; culture of 125; doner kebab in 104;

flatbread 43, 161; Georgian 196-7; gingerbread 183; inventories of shapes 14; lavash 43; loaves 191; making 111, 130; and meat 126; Russian drink kvass 190; rye 182; white 132

Brieux, E. 179

British Empire and food 20

Brünn/Brno 144

Brünner Wochenblatt 144

Buchteln (original Czech brioche buchta) 146

Bucovina 139, 143, 144, 147

Bucovinian cuisine 143

butter 126, 131, 161, 167, 184

cakes (Torten) 150

Camilleri, A. 3

Capuana, L. 69

Capuzzo, P. 22, 205

Carême, M.A. 16

Caritas Report on Migrants 12-13

Carnival 126

carp 142

Carson, R. 85, 87

cassata 74

Castelvetro, G. 132

Catalonia 9, 10, 20, 127

Catholic Church 132

Catholicism 18, 132, 140, 150, 164

centro de estudios historicos 14

Champagne 51, 146, 183, 197

chefs 9, 10, 18, 22, 67, 87; Austro-

Hungarian 150; award-winning 88;

Child, Julia 89; Gundel, Károly 149;

male chefs 139; Ruscalleda,

Carme 9; Sangrisava, Bo 208; Stefani,

Bartolomeo 134; Tower, Jeremiah 89

chefs, Austro-Hungarian 149-51

Chef's Table 208

Chez Panisse 88-9

chicken tikka masala 13

Child, J. 89

China 61,112, 188; western food in China 188-9; see also Russian diaspora in Shanghai
Christianity 126-7; and European food 131-2

cities and marketplace 142-4

Ciundziwicka, A. 17

civil servants 21, 23, 138, 139

Club of Rome 87

Cocchiara, G. 75

colonialism 20-1

Columbian exchange, the 19-20, 46

combat gastonomique 12

commodity 46, 63, 205; heritage 46, 205

communes 86-7

consumer culture 52, 202

Convention for the Safeguarding of the Intangible Cultural Heritage 5

Cook, R. 13

cookbooks: American 15-16, 180;

Armenian 158, 159; Austro-Hungarian

149-51; Ottoman-Turkish 156-62,

164-8; and women (gender) 16-19

cooks 5, 13, 14, 21, 23, 38, 89,

139, 146-7; army 144; Bohemian 150;

Chinese 191; Czech 150;

experienced 145; non-Jewish 145;

organizations of 183; Palestinian

male cooks 18; professional 143, 207;

Viennese 148, 149; see also chefs

corns 143

Cougnet, A. 71

counterculture see protest and counterculture, $1960 \mathrm{~s}$

couscous $9,11,12,43,73$

Croatia 146

Croce, B. 70

Crocioni, G. 70

Cuciniera bolognese 67

Culinarium Museum 101, 102-3, 108-9, 109

culinary culture: Armenian 159; doner kebab 104; elements of 59; European 161; homogeneity of 166; Jewish 19, 143, 150, 159, 190;

Kurdish 158; Ottoman 156, 158, 160, 165-7; Russian 196, 202; and traditions in museum work 100 ; Turkish 156, 162

Culinary Education in Alla Turca and Alla Franca Style 161

culinary heritage 155; Austrian identity 151; Belorussian 18; dishes of 18; dynamics of 46; European 138, 
152, 171, 209; multi-religious cosmopolitan 158; Ottoman 155, 157, 158, 162-6; Ottoman-Turkish 155-6; Turkish 155, 156, 160, 162

culinary nationalism 8 culinary tourism $37,41,71,156-7$

cultural assimilation 131

Czechs in Prague 144

Czernowitz 145

Dağdeviren, M. 208

Darjeeling tea 51

Daugbjerg, M. 6

de la Varenne, F. P. 66

Denmark 10-11, 17

de Roberto, F. 69

de Soucey, M. 42

Detchev, S. 165

diasporas 9, 21, 24, 98, 188, 192, 193, 200, 202; Russian (see Russian diaspora in Shanghai)

Die große Prato 151

Die österreichisch-ungarische Monarchie in Wort und Bild 148

Die Süddeutsche Küche 151

dietetic culture, European 127

Dimitriades, K. 191

dinde 20

Dishes Cooked in Armenian, Rum, Jewish and Muslim Houses in Istanbul 158

Douglas, M. 7

Dreher, A. 140

East Germany 108

elite $17,23,39,66,74,75,128,134,142$, $150,159,161,162,164-5$

Elle 18

empires 7, 20, 21-3, 46, 138, 152, 208

Enzensberger, U. 84

Ersatz (replacement foodstuffs) for traumatic loss 112-18

Ertürk, N. 161

Escoffier, A. 87

ethnic cooking 192

ethnicity 111, 138, 158

European cuisine: Arabs and 127-8; Christianity and 126-7, 131-2; dietetics and 127; globalization and 132-3; grammar of food and 129-31; haute cuisine 87,131 ; history and geography impact on 128-9; at international exhibitions $180-5,181$; introduction to concept of 125 ; invention of regional cuisines in 133-5; medieval imprint on 125-6; new religious contrasts, new forms of integration in 131-2; novelle cuisine 87-90; revolution in taste of 131; in Shanghai (see Russian diaspora in Shanghai); see also Austro-Hungarian cooking

European Union 36, 37, 55, 108, 111,208

Every Type of Dishes Prepared in Istanbul (Tsarigrad) Style 164-5

exiles 21

exoticism 10

fagioli 149

falafel 9

farming, organic 85-6

Faroe Islands 10

fast food 90, 93

Ferguson, P. 8

feta cheese 8

Fifty Turkish Dishes in History 156

Finland 10

Fiume 24, 140, 142

500 Years of Ottoman Cuisine 157

flatbread 43

foie gras 9,87

folklore 70,75

fondua 71

fondue 71

food: as commodity heritage 205; in European cuisine (see European cuisine); fast 90, 93; future of traditions and heritage with 62-4; global market for (see global food market); as heritage 3-7; heritagization of (see heritagization of food); international labelling of 38-44, 40; locality of (see locality of food); in museums (see museums, food in); national branding through 9-11, 42, 75-7, 160-2;

nationalism and (see nationalism); nostalgia in engagements with 107-12, 109-10; organic 85-6; protest and counterculture impact on attitudes toward (see protest and counterculture, 1960s); regional cuisines (see regional cuisines); religion and 19, 126-7, 131-2, 150; slow (see Slow Food); 
spatial dimension of 209-10; symbolic value 35 ; tradition, heritage and $52-4$ food wars $8,162,205$

Fragner, B. 165

France 7, 11-12, 14, 17, 20, 54, 56, 66, 67, $72,77,87,88,90,128,132,133,146$, 174,175

freezing practices 205-6, 209

French cuisine 15-16, 18, 39, 66, 67, 70, 74, 88, 164, 168, 199

French Revolution 13-15

frittata 149

frontiers 75,171

Fucini, R. 69

Gabay, S. 190-191

Galbani, B. D. 76

Galbani, E. 76-7

Galbani cheese 75-7

galuska in Hungary 147

gastrodiplomacy 9-11, 42-3

gastrolinguistics 43

gastronationalism $8,42-3$

Gastronomic meal of the French

$8,161-2$

gastronomie 87-8

Gastropolitics in Hindu South Asia 207

Gautier, T. 174

Gdańsk Museum of the Second World

War 113-15, 114, 116

gefille Fisch 142

Gellner, E. 7

Gelmini, M. S. 12

gender 23; and cookbooks 16-19; differences 41; division of the profession 139 ; roles 83

geographical indications 38-44, 40

geographical origin $36,51,139$

geography of food see locality of food

German 140

Germanic and Slavic populations 125

Germany 11, 15, 22, 67, 77, 101, 104, 148; beer 90; Italian restaurants 22 ; pork in 133; Turkish communities of 101-4

Gilmore, J. 52

Glasse, H. 20

global ethnoscape 4

global food market: Austro-Hungarian empire and 142-4; food, tradition and heritage in 52-4; future of food traditions and heritage in 62-4; intellectual property and 54-6; introduction to 51 ; limits of intellectual property approach in 56-8, 57

globalization 4, 21; European culture and 132-3; see also global food market

Globally Important Agricultural Heritage Systems (GIAHS) initiative 61

Global South 8, 51, 52, 56

Global Thai Program 9-10

gnocchi 130, 147

Godey's Lady's Book 16

goose 126

goulasch 15

Gove, M. 208-9

grammar of European food 129-31

Graz 145, 151

Greeks 8, 84, 125, 127; heritage 125, 128 , $165,172,205$

Guida gastronomia d'Italia 71-4

gulyás 149

Gundel, K. 149

Gvion, L. 19

Habsburg Empire see Austro-Hungarian cooking

halal food 12

Hale, S. J. 16

halloumi 208

Harrison, R. 54

haute cuisine 87,131

heimatliche tradition 150

Heitz, J. M. 150

heritage vegetable discourse 4

heritagization of food 35-8; focusing on time and not on space 209-10; future of 62-4; geography and (see locality of food); nouvelle versus authentic cuisine and 88-90; observing, describing, but not freezing 205-6; respecting differences in 209; using the past in 44-6; see also nationalism

Hess, A. 151

Hess, O. 151

Hirschwitz, Fräulein 149

Histoire de la vie privée des français depuis l'origine de la nation jusqu'à nos jours 66 historians 7, 8, 9, 14, 21, 41, 109, 127, 205 Hobsbawm, E. 7, 53

Hofer, J. 78 
Holtzman, J. D. 98

Horel, C. 17

Hotels and Restaurant Association of Great Britain 13

House of European History 101

hummus 9, 43

Hungarian population 140, 143

hybridism 138-42, 141

Iceland 10

identitaires 12

Il Bel Paese 76

Il cuoco milanese e la cuciniera piemontese: manuale di cucina indispensabile per ogni ceto di famiglia 67

Il volto agricolo dell'Italia (The Agricultural Face of Italy) 72

Imperial Taste: 700 Years of Culinary Culture 156-7

ingredients 6, 23, 58, 61; all-white 127; Arab 74; exotic 65; flavour of 89 ; heritage and 44 ; history of 19 ; migration of 100 ; mock 111; quality of 63 ; range of 65 ; rusticity of 23,52 ; unconventional combinations of 84 ; variety 125 ; Western-style 188-9

Intangible Cultural Heritage (ICH) 5, 36-8, 40, 61-2

intellectual property $54-6$; limits of $56-8$, 57 ; models not based on 58-62, 60 intercultural contact through food in museums 100-7, 102-3, 105

international exhibitions 180-5, 181 international food market see global food market

Islaburger 12

Islam 11, 12, 73, 126, 128

Israel 9, 190

Italy $10,11,12,72$; as a brand $75-7$; Conference on Soft Power, Made in Italy and Italian Lifestyle in the World 10; national unification 66; post-unification 16; regional cuisines of 70-5; Slow Food map of 94

\section{Jahrmarkt 143}

Japan 4, 8, 14, 19, 39, 43, 52, 179, 189 , 190, 192, 195, 200, 202

Jewish cooking 19, 126, 128, 142, 143, 145, 150; Ashkenazi Jews 189;
Galician Jewish cuisine 150; Palestinian food by 19; in Russian diaspora in Shanghai 189-90; Russian Jewish expatriates 190; traditional 150

Jews 9, 19, 143; anti-semites 146;

Ashkenazi 189; in Hungary 150;

Israeli 18; pork 9, 126; Sephardi 75

Joseph, F. 138-52

Kältetechnik 140

Karaosmanoğlu, D. 157

Kebab 11, 15, 62, 103, 104, 105, 161, 165,167

keşkek 43

Keys of Cooks 158

Kimber, H. D. 13

kimchi 8, 43

Kirshemblatt-Gimblett, B. 54

knedliky (knödel) 146

knödel 147

Kolas,Y. 18

Konditor 149

Köstlin, K. 151

Krautmarkt (cabbage market) in Brünn 144

Kristensen, D. E. 84

Kunzelmann, D. 84

Kurdish Culinary Culture and Kurdish Dishes in Anatolia 158

labelling, international 38-44, 40

La cocina antigua española 18,67

La cuisine anglaise et la pâtisserie 17

L'albergo d'Italia 75

Langshans, R. 84

L'any del manjar, cuina i gastronomia, Catalonia 10

L'Art de la cuisine française au dix-neuvième siècle 16

La scienza in cucina e l'arte di mangiar bene $12,67,68,209$

Latin 140

Latin America 14, 84

La vie et la passion de Dodin-Bouffant, gourmet 17

Le cuisinier françois 66

Leer, J. 10

Lega Nord 11

Legrand d'Aussy, P. J.-B. 66

Lent 126, 132, 159, 165

Le vie d'Italia 75 
Lévi-Strauss, C. 7

Libro de arte coquinaria 66

Lieux de mémoire 7

Limits to Growth 87

L'Italia vinicola e agraria 72

Lithuanian Housewife 17

Lithuanian Women's Catholic

Association 18

localism 12

locality of food: birth of regional cuisines and $70-5$; European cuisine history and 128-9; geographical roots and 65-7, 68; Italy as a brand and 75-7; from regional tradition to place-less nostalgia 77-9

lokum 208

Lowenthal, D. 6

"MacDonaldization" 3-4

Machado y Alvarez, A. 14

Maghreb 12, 41, 61, 73

makaroni noodles 148

Malaparte, C. 69

malbouffe 3, 151

Marescalchi, A. 72, 73

Markaris, P. 3

market 6, 36, 39; global food 42, 51-64

Martínez,V. 208

Martini, F. 69

Martino, M. 66

Mastriani, F. 69

McNamee, T. 89

Meades, J. 13

meat: chopped 18; cultural 26; for

Jews 19; strong-flavoured 131

meat-eating 128

medieval European food 125-6

Mediterranean diet 38, 43, 61, 135

melšpajz 148

Middle Ages 6, 19, 65, 75, 125, 127-34, 208

migrations 21-2; food in museums and 100-7, 102-3, 105; see also mobility/ travel

Misasi, N. 69

mixophobia 11-13, 12

mobility/travel 185-6; Austro-

Hungarian cooking and 144-7;

international exhibitions and 180-5, 181; station buffets 174-80, 175-6; transmission of tastes through 171-4 modernity: European cafés in Shanghai and 199-202

Möhring, M. 22

Montanari, M. 19

Moravia 140, 143, 146, 150

Mulino Bianco Barilla 78-9

multiculturalism and food in museums 100-7, 102-3, 105

multilinguism 143-4, 199

multinational empire, food in see Austro-Hungarian cooking

Museum of European Cultures (MEK) 103-6, 105

museums: Auschwitz Museum and Memorial 115; Beamish Open-Air Museum 107-12; Culinarium Museum 101, 102, 102-3, 108-9, 109; food in (see museums, food in); Gdańsk Museum of the Second World War 113-15, 114, 116; intercultural contact through food 100-7, 102-3, 105; migrations and food in 100-7, 102-3, 105 ; multiculturalism and food in 100-7, 102-3, 105; Museum of European Cultures (MEK) 103-6, 105; Tränenpalast Museum 112-13; see also museums, food in

museums, food in 118-19; as Ersatz for traumatic loss 112-18, 114, 116-17; introduction to $98-100$; multiculturalism, migration and intercultural contact with 100-7, 102-3, 105; nostalgia in engagement with 107-12, 109-10

Muslims 11, 19, 140, 145, 159, 164

Napoleonic wars 13

Naschmarkt (Vienna) 148

national branding through food 9-11, 42, 75-7, 160-2

national dish 15

national identity $11,13,15,43-4,70$, $139,144,155,160,161,165$

national identity and hybridism 139-42, 141

nationalism: food heritage and 7-9, 208-10; gastrodiplomacy in 9-11; gender and culinary 16-19; 19th-century food 13-16; populisms and mixophobia in 11-13; see also heritagization of food nation-building $5,7,16,17,155,161,167$ 
Native American foodways 21

Nedim, F. 161

Neuman, N. 10

New Cookbook 158

New Land, The 18

New Left 83-4

New Nordic Cuisine (NNC) 10-11

Nicholas I Tsar 15

19th-century food nationalisms 13-16

nongovernmental organizations (NGOs) 56, 58

Nora, P. 7

nostalgia 4, 77-9, 98-9; in engagements with food 107-12, 109-10; reflective 107

nouvelle cuisine $87-8,93$; versus authentic cuisine 88-90

Novak-Marković, O. 18

officers 138, 144, 165

Ojetti, U. 71

olive oil 22, 159, 161

100 specialità di cucina italiane ed estere 67

Organic Gardening \& Farming 85-6

Ostalgie 109-10

osterie 90

Österreichische Küche 151

Ottoman Cuisine: A Rich Culinary Tradition 157

Ottoman-Turkish cuisine 166-8; constructing Turkish national cuisine and 160-2; cosmopolitan character of 158-9; introduction to 155-6;

Ottoman culinary heritage and 162-6, 163; reimagining 156-8

palacsinta 149

Palestina 9, 12, 43, 61, 73

Palestinian Heirloom Society 9

paprika 139, 142, 162

Parini, G. 77

parmigiano reggiano 36,51

pasta (Slovenia, Italian provinces) 147

patrimoine 6

patrimonialization 14, 35

peasant food 147

peasant women 144, 178

peoples and regions in food

heritage 69-70

Perfect Cookbook of Alla Turca and Alla

Franca Dishes and Desserts, The 161 pesto 71

Piedmontese cuisine 74

Pilsen (Plzeň) 142

Pine, J. 52

Piovene, G. 77-8

Pitré, G. 69

Place-based labels 5, 36

polenta 130

Polish population 143

Pollan, M. 95

populisms and mixophobia 11-13

pork 126; cappelletto 129; culture 129;

dishes 159; in Germany 133; Jews' 9;

pork-based soupes identitaires 12

Portinari, F. 91

Potemko, F. G. 193

Powidl powid 146

Pratesi, M. 69

Prato, Katharina 17, 151

presentism 3-4

Presidia project 58-9, 62

Pressburg (Poszony) 145

Prince albert pudding 15

Protected Designation of Origin (PDO) 5, 56

Protected Geographical Indication (PGI) 56

protest and counterculture, 1960s: high gastronomy impact of $87-8$; new cultural meaning of kitchens and dining rooms with 83-7; nouvelle versus authentic cuisine and 88-90; resisting fast life by slowing the food $90-5$, 92, 94; transformative power of 95

Protestantism 140

Protestant Reformation 131-2

quenelles 147

race $13,17,100,104,126,202$

Radetzky-March 149

Ragusa (Dubrovnik) 142

railways $139,172-3,179$

railway travel see mobility/travel

ravioli (Polish pierogi or Ukrainian varenyky) 147

recipes 10, 15, 17, 20, 68, 70, 129, 151;

Armenian cookbooks 158; Artusi 67; authenticity 3; for blancmange 127; book of, Romania 15; books 23,45 , 66, 67, 100, 115, 149, 209; culinary 
techniques 166; European 159;

Europe's books 127; Fifty Turkish

Dishes in History 156; French 67, 146;

Lithuanian zeppelins 18; Ottoman and

Italian 138; secret 19; Slavic 202; of the sobressada 15; Turkish 156; unusual 183

Recipes from Rums of Istanbul 158

Redzepi, R. 208

reflective nostalgia 107

regional cuisines: birth of 70-5; European invention of 133-5; example of 75-7; place-less nostalgia and 77-9

Reichard, O. 173

religion and food 19, 126-7, 131-2, 150

restaurants 4, 10, 16, 134, 140, 207;

Annam 183; Caucasian 196, 197; chefs in traditional 88; Chez Panisse restaurant 88; cosmopolitan 20; Creole 183; ethnic 21; European Japanese 19; garish restaurants 198; Grand Restaurant St George 191; high-end 157; Italian 22, 71;

Jewish-Russian 191; Kavkaz 200; luxury 182; Mrs Gabay's Olympia Restaurant 191; Noma 10; Olympia Restaurant 190; Ottoman-style 157; in Paris 14; Parisian-style 199; Russian 198, 200; Shanghai 23; Shouin's 192; Tkachenkos' 195; urban 199; Western 200; Western-style 189, 191

Rettigová, M. D. 17, 150

Ridder, D. 84

risotto 149

Rogers, B. 7

Rohdewald, S. 157

Roman Catholicism/Orthodoxy 140

Romania 8, 15, 129, 145, 168, 185

Romanian population 143

Romans 125, 127

Rouff, M. 17

Rumpolt, M. 9

Ruscalleda, C. 9

Russian diaspora in Shanghai 202; cuisine of 196-9; ethnic food production in cosmopolitan city and 189-96; European cafés as clandestine engine of modernity for 199-202; introduction to 188-9

Sabotić, I. 148

Sacher Hotel 149 safeguarding without freezing 44

Sammells, C. 39

Sangrisava, B. 208

Şavkay, T. 157

Scappi, B. 9

Scherbakoff, M. 197

Schlumberger entreprise 146

schnaps 145, 146

Schratt, K. 149

Sephardic Cuisine 158

Serao, M. 69

serbischer Karpfen 142, 148

Serbs 142, 148

Serra, R. 69

servants 143, 146, 150, 178-9

Shanghai see Russian diaspora in Shanghai

Shanghai Zaria 194

shared heritages 43

shashlyk 197

Shouin, V. 191-2

Silent Spring 85

Silkiss, H. M. 190

Slavic populations 125, 140

Slovak halušky 147

Slovakia 146

Slovenes around Trieste 144

Slovenia 146

Slow Food 58-9, 60, 62; 1960s counterculture and 90-5, 92, 94

Slow Food Manifesto - International Movement for the Defence of and the Right to Pleasure 91

Smith, A. 89

sobressada 15

socca 11-12

sociability 90

social classes: bourgeois $16,66,83,85,87$, 140, 143, 145, 146, 147, 150, 177, 180; middle classes $18,23,67,71,75,87$, 145, 200, 202; professional merchants $21,23,75,144,188,199$; servants 143 , $146,150,178,179$

Soldati, M. 77, 78

Spalato (Split) 142

spatial dimension to food heritage 209-10

sponge cake 74

station buffets as multiscale food exchange territories 174-80, 175-6

Staub, A. 83 
Stiftung Flucht Vertreibung Versöhnung

(Foundation for Flight, Expulsion and

Reconciliation) (SFVV) 115-16

Stoppani, A. 76-7

Storia del vino e della vite in Italia

(History of Wine and Vines in Italy) 72

student protest see protest and

counterculture, $1960 \mathrm{~s}$

Sundancer, E. 86-7

surclassement patrimonial 5

sustainability 52, 63, 89, 91, 207, 208

Sutton, D. 99

Suzanne, A. 17

Sweden 10

Tafelspitz 138-52

tahini 161

Temesvár 145

tempura 19

terroir 4, 8, 10-11, 35-6, 207-8

testenina 148

Teufel, F. 84

time dimension to food heritage 209-10

Timeless Tastes 156

Tkachenkos brothers, Shanghai 194-5, 198-9

Tokaj 142

Törley entreprise 146

Toschi, P. 75

tourism, food-based 9, 37-8

Tower, J. 89

trademarks 55

Trade-Related Aspects of Intellectual Property Rights (TRIPS), Agreement on 55

tradition: as field of social action 52-3; without history 44-6

Tränenpalast Museum 112-13

Transylvania 143

travel see mobility/travel

Traveller's Guide to Europe, $A 173$

Trieste 140

Turkish-Balkan specialities 148

Turkish delight 208

Tuscany 67, 71

Ubertazzi, B. 8

Ukrainian (Ruthenian) population 143

United Nations Educational, Scientific and Cultural Organization

(UNESCO) 51, 54, 162, 205, 209;
Intangible Cultural Heritage (ICH) list 5-6, 22, 36-8, 40, 41, 43, 44, 51, 61-2, 162; on international labelling $38-44,40$

United Nations Food and Agriculture

Organization (FAO) 59, 61

universal exhibitions 7

Ünver, S. 156

Valdemar's Day 11

Vásquez Montálban, M. 3

Verga, G. 69

Viaggio in Italia 77

Viaggio nella valle del Po 78

Viennese cuisine 143; invention of 147-9

vlitki 148

Vojvodina 143

von Rokitansky, M. 151

wartime cooking 111

Waters, A. 88-9, 207-8

Welz, G. 205-6

West Germany 90

Whitehead, C. 6

Wiener Bürger-Küche 150

Wiener Küche 151

wine 23; Alto Douro region 61; Bordeaux 54, 183; Burgundy 11; consumption 84; Dalmatian 142, 144; French 12; Georgian 197; Hungarian 142; maker 72; of Piedmont 73; region 140; wine-growing associations 72

Winikoff, L. 191

women 11, 44, 147, 148, 150, 161, 178, 190; and cookbooks 16-19, 140;

Frenchwomen 200

working class 41, 52, 185

World intangible heritage 6, 205

World Intellectual Property Organization (WIPO) 62

World Trade Organization (WTO) 55

xenophobia 12

Yeğen, E. M. 161

Yerasimos, M. 157

Zakouskas (Zakuskas) 15, 196, 198

Zara (Zadar) 142

zatar 9 